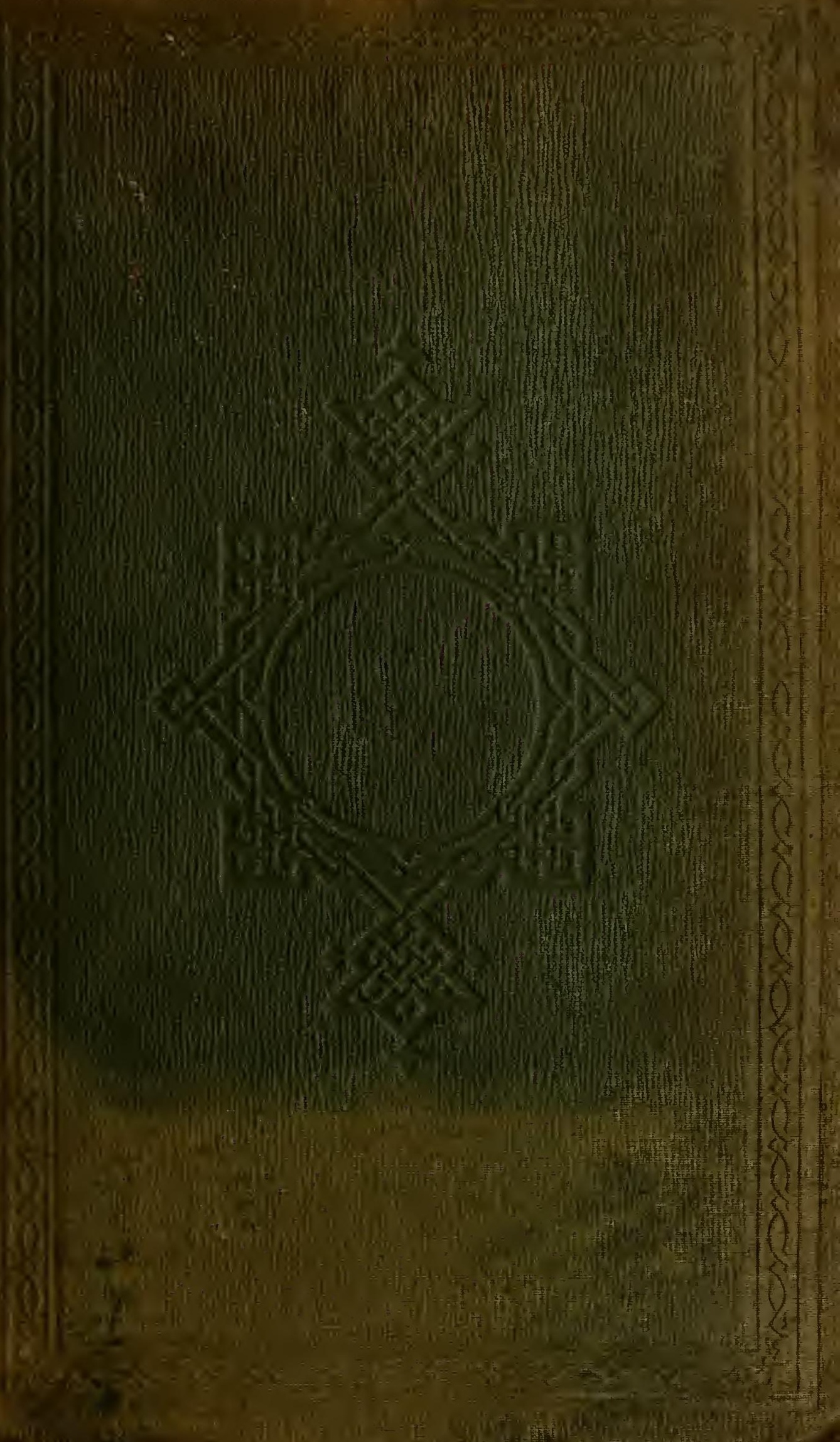


lat 

. 



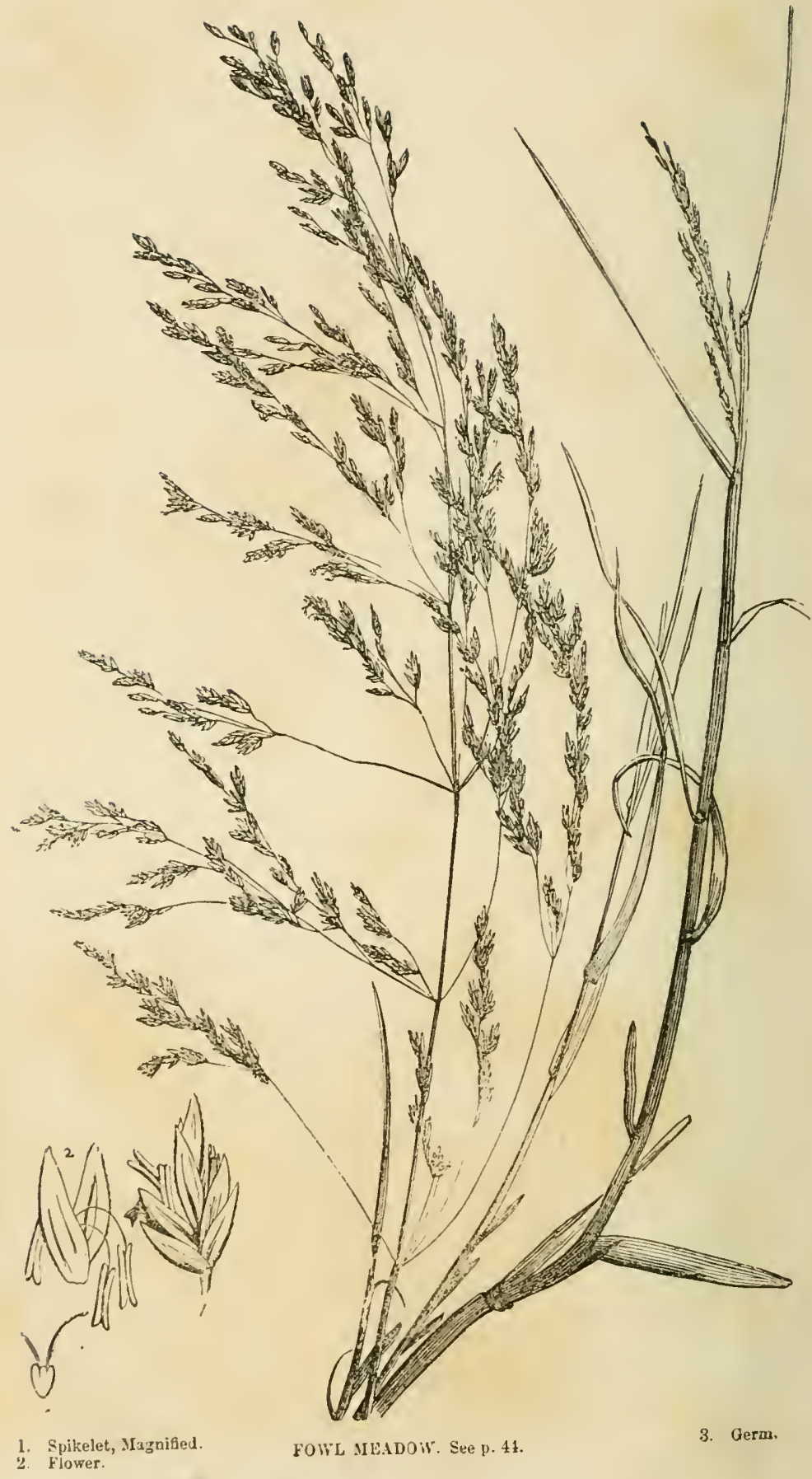




\title{
PRACTICAI，TREATISE
}

oN

\section{GRASSES AND FORAGE PLANTS:}

\author{
COMPRISING
}

THEIr NATURAL IHSTORY, COMPARATIVE NUTRITIVE VALUE, METIODS OF CUltivating, CUTTING AND CURING, AND TIE MANAGEMENT OF GRASS LANDS.

BY CHARLES L. FLINT, A.M., BECRETARY OF THE MASSACHUSETTS STATE BOARD OF AGRICLLTURE, MEMBER OP THB BOSTON SOCIETY OF NATURAL HISTORY, ETC. ETC.

\section{NEW YORK:}

G. P. PUTNAM \& CO., 321 BROADWAY.

$$
\text { LON D ON : }
$$

N. TRÜBNER \& CO., 12 PATERNOSTER ROW.

$$
1857 \text {. }
$$


QL34

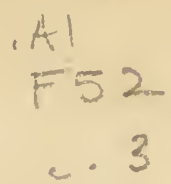

Entered according to Act of Congress, in the jear 185 ,

By George P. Purxam \& Co.,

In the Clerk's Office of the District Court for the Southern District of New York.

Willay Waite, Printer,

4. Spring Lane, Boston. 


\section{P REF A C E.}

It has been my endeavor, in the following pages, to treat my subject in a plain, simple manner, so as to enable the firmer to distinguish between the different species of grass by means of the descriptions given, and to awaken an interest in the pursuit of the subject, treating cursorily of the natural history of the grasses, and indicating to the reader the vast field of study which lies open to him in this department.

The illustrations, which will be found to be very carefully and accurately drawn, will tend to render the understanding of the text more easy, and thus make interesting to all much that would be attractive only to the scientific student of botany if they were omitted.

In looking at the subject in its cconomical aspect, I have tried to give all that is known to be of value, and have presented the conclusions of practical men in regard to points about which the opinions of individuals actirely engaged in agriculture differ. It has becn my object, in a word, to give the work an eminently practical character, and not to make it merely a collection of doubtful theories and vague generalities. It must be left to the reader to determine how far I have accomplished this purpose. 
The local names of many species of grass are so numerous that I can hardly hope to have given them all, in erery case, though what are known to me I have given as synonyms. Should the work meet with such favor as to call for another edition, I shall attempt to make it less imperfect in this respect.

It may not be irrelevant to remark here that but little is known of the real economical value of some of the grasses which I have described, and it is by no means impossible that many of our wild grasses which we now look upon as almost worthless, may be found at some future time to possess raluable nutritive qualities, and thus be added to our list of grasses which may be profitably cultivated.

It seems to be altogether unnecessary to multiply authorities, either here or in the body of the work, to prove the importance of the subject. Perhaps the most forcible expression of opinion on this point may be found in the French writer who asserts that the term grass is only another name for beef, mutton, bread and clothing; and in the Belgian proverb- "No grass, no cattle; no cattle, no manure; $110^{\circ}$ manure, no crops!" For myself I can only say that if my researches,-imperfect as they doubtless have becn,- - shall have the effect of creating a more general interest in the subject, and leading to more careful inquiry and more general and accurate investigation, I shall be amply rewarded for any labor I may have undergone in the preparation of these pages.

C. L. F.

Boston, Feb., 1857. 


\section{GRASSES AND FORAGE PLANTS.}

I propose to speak of the grasses, a family of plants the most extensive and the most beautiful, as well as the most important to mankind. It embraces nearly a sixth part of the whole regetable kingdom; it clothes the globe with perpetual verdure, or adorns it at fixed seasons with a thick matted carpet of green, none the less beautiful for its simplicity, and it nourishes and sustains by far the greater part of the animals that serve us and minister to our wants.

When we consider the character of our climate, and the necessity of stall feeding during five or six months of the year, for which we are dependent mainly on the grasses, we shall see that in an economical point of riew, this subject is one of the most important that can occupy the farmer's attention.

The annual value of the grass crop to the country, for pasturage and hay together, is not less than $\$ 300,000,000$.

I shall endearor to give a brief account of the natural history or description of all the useful grasses found in our fields and pastures, partly because it is essential to a complete understanding of the subject, and partly because there is at present no popular treatise on the sulject within the easy reach of our farmer's, and something of the kind is needed for reference; but I shall confine myself mainly to a plain and practical treatment of the subject, making such suggestions as I think may be useful, on the cultivation, cutting and curing of the grasses for hay, the comparative value of the difierent rarieties, and the general management of grass lands.

This subject, familiar to me from my earliest recollection, has occupied my attention almost exelusively, during the past 
year. Within this period I have been able to make an exten sire collection, embracing nearly all the varieties of our New England grasses, for preservation in the Agricultural Mnsseum connected with my office.

-The grasses are variously divided, classified and arranged. They are sometimes designated as natural or artificial; the former comprising all the true grasses, - that is, plants with long, simple, narrow leaves, each leaf having many fine veins or lines running parallel with a central prominent vein or midrib, and a long sheath (Fig. 1.) divided to the basc, which seems to clasp the stem, or through which the stem seems to pass, the stem being hollow, with rery few execptions, and closed at the nodes or joints; and the latter-the artificialcomprising those plants, mostly leguminous, which have been cultivated and used like the grasses, though they do not properly belong to that family, such as the clovers, sainfoin and medic. In common language the term is often used in a sense not strictly proper, being not unfrequently applied to any lierbage which affords nourishment to herbaccous animals, inchuding, of course, not only many leguminous plants like clovers, but some others which would more properly be called forage plants.

But in botanical language, and speaking more precisely, the grasses, Graminece, embrace most of the grains cultivated and used by man, as wheat, rye, Indian corm, barley and rice; all of which will be at once recognized as having leares and stems very similar in shape and structure to most of the plaints popularly called grasses.

$A$ s the general appearance of plants is often greatly modified by climate, soil and modes of cultivation, it is important to fix upon certain characteristics which are permanent and unaltered by circumstances, by means of which the particular genus and species may be identified with ease and certainty. It is evident that these characteristies could not be simply in the leares, or the stems, or the size of the plant, because there will be a great difference between plants growing in a poor, thin, sandy soil, and others of the same species on a deep, rich loam. Botanists have, therefore, been compelled to resort to other peculiarities to distinguish between different species; and the terms used 
XATURA IISTORY.

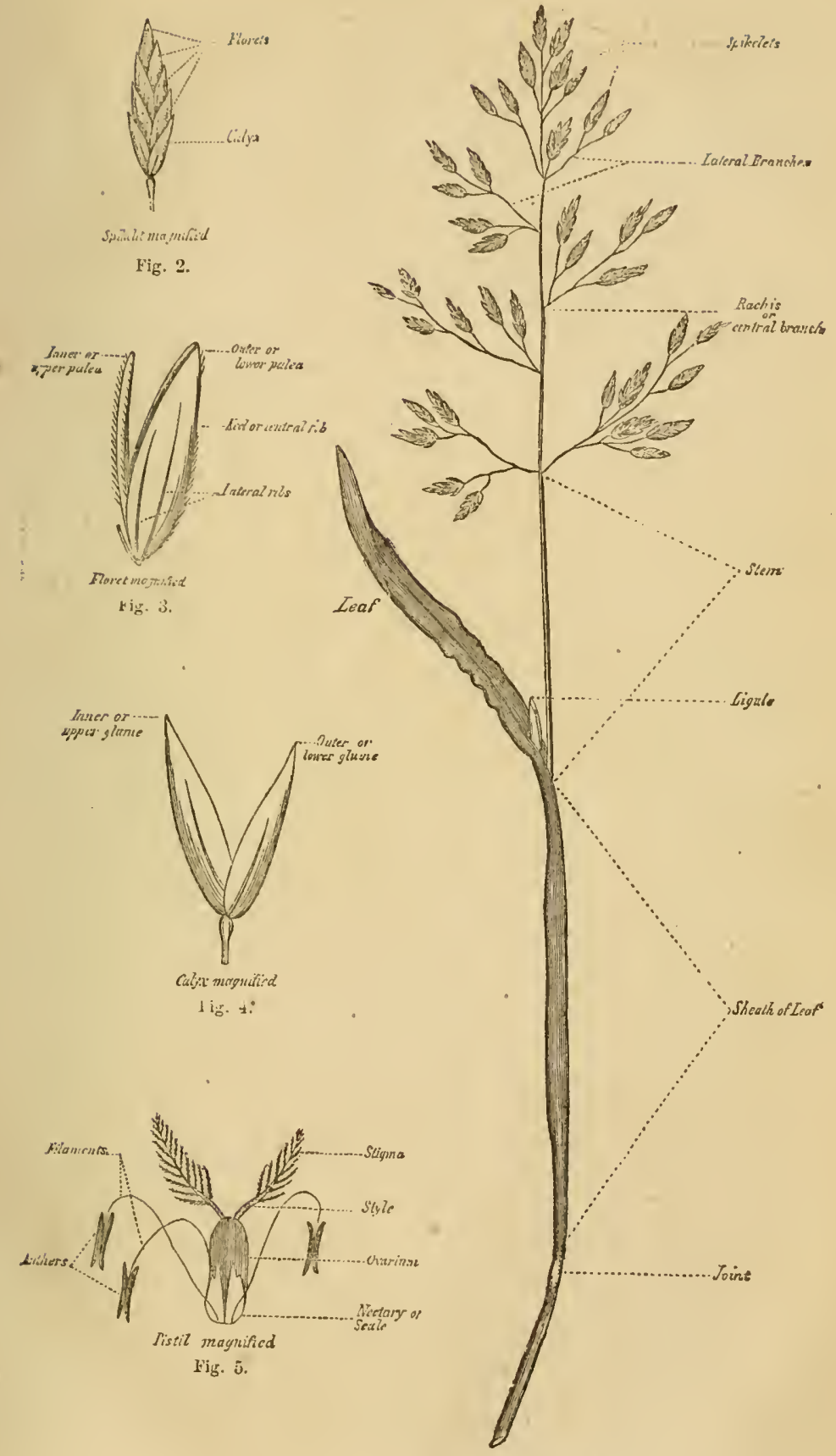

Fig. 1. Annual Spear Grass. 

to express these, like the terms used in other departments of natural history, are technical; and hence, in detailing the natural history of the grasses, the use of technical language to a greater or less extent, camnot be aroided. I shall endeavor, however, by the use of plates and synonyms to bring the description of species within the easy comprehension of every one who will carefully examine the subject.

The flowers of the grasses are arranged on the stem in spikes, as where they are set on a common stalk without small stalks or branches for each separate flower, as in Herds-grass, (phleum pratense,) or in panicles, or loose subdivided clusters, as in orchaud grass, (dactylis glomerata.) A panicle is said to bo loose or spreading, as in redtop, (agrostis vulgaris,) when the small branches on which the flowers are set, are open, or extended out freely in different directions; it is said to be dense, or crowded or compressed, when the branches are so short as to give it more or less of the spike form.

The spikelets (Fig. 2) liave a calyx, (Fig. 4) containing one, two or more florets, (Fig. 3.) This whole arrangement will be seen in Fig. 1, which represents a stảk of the common annual spear grass, (poa anmua,) a plant familiar to every one as often troublesome in gravel walks and on hard, dry soils. Here the joint, the stem or culm, clasped by the sheath of the leaf, the leaf itself, the ligule and the spikelets, all distinetly appear, and the reader will do well to make-himself familiar with the few technical terms used by a study of this figure, in connection with Fig. 2, where the spikelet is so magnified as to show the florets and the calyx very distinctly, all of which are generally very easily seen with the naked eye, and Fig. 3, showing a floret still more magnified, with its two palex, the outer palea being the longer and generally kecled,-that is, haring one, three or more longitudinal ribs, often haring on the back, base or summit, an awn or beard of different lengths, as in the oat and brome grasses, the inner palea with two separate fringed ribs, each on a fold at the side. The calyx, bract or outer seale of the spikelet, is showi very much magnified in Fig. 4, composed of two glumes, the upper and lower, the upper glume being the larger. One or both of the glumes are sometimes wanting.

In Fig. 5, is shown the pistil magnified, consisting of the nectary, composed of one or two fleshy scales, (in some plants 
of this family both on one side, in some, entirely wanting,) and the germ, ovary, or seed bearing portion of the pistil. The stamens are also seen in the same figure, consisting each of a bag filled with a fine powder or pollen, supported upon a stalk or filament which is analagous to the stalk or stem of a leaf, while the bag which holds the pollen, called the anther, corresponds to the blade or body of the leaf. These are essential parts of the flower. At a particular stage of its growth, the anther, bursting, seatters its pollen, some of which, lighting upon the summit of the stigma, is said to fertilize it, when the new seed begins to enlarge, and a germ is formed capable of producing other plants.* This process is very apparent.to the observation of the farmer in the ease of Indian corn, on which the pollen is so alundant that it may be shaken off in clouds. It falls upon the stigmas or " silks," one of which is attached to each embryo seed or germ; and without this particle of pollen, the seed would not be capable of attaining maturity. The same is seen less palpably in the other grasses, as, for instance, in Herds-grass. The same arrangement occurs in this whole family of plants, though it is more evident in Indian corn, on account of its size, than in the smaller grasses. The anther, as will be seen, consists of two cells-rery prominent and hanging, supported on the long, slender filaments, and forked or divided at the end. The two short and smooth styles rise from the summit of the orary, and the stigmas are feathery or rough, sometimes branched or compound. Only one seed is contained in each ovary, and each seed is covered, when mature, with a thin husk or hull ealled the pericarp, which originally formed the germ or ovary; and the ripe seed or fruit is only the ovary arrived at maturity. The substance or albumen of the seed of all the grasses is mealy or farinaceous, as wheat, for instance, or rye, or Indian corn, which are most used as seeds, on account of their size and productiveness.

These are the prominent characteristics of this great and universally diffused order of plants, constituting, as it does, the chief support of animals as well as men. They belong, as has

* The germ is the first part of the seed that is distinetly formed, and hence, if Indian corn is plucked while "in the milk," or in a green state, fit for boiling, it wili germinate the next year as well as if it were allowed to ripen. 
been seen, to other plants than those commonly called grasses, the order graminex, as I have already stated, cmbracing the grains, as wheat, barley, rye, and many others, while it does not include the elovers, which properly belong to the order of leguminous plants.

These characteristics, or at least the most important of them, will be very easily kept in mind, as the long, narrow and lance slitped leares, and the mealy nature of the seeds which makes nearly the whole fanily valuable and nutritious; but in studying the distinctive characteristies of the different species and varietics particularly raluable or interesting to an agrienlturist as forrage plants, it will be necessary to depend more upon the technical terms already referred to, though these will be aroided, or explained in the context as far as possible.

It will have been observed that considerable importance is giren to the flowers and seeds as distinguishing characters of the grasses. It will often be found difficult from the mere cxterual appearance of a variety of grass to determine to what species, or eren to what genus it belongs, so great is the resemblance between the different species of this class of plants; but with the aid of a small magnifying glass there will very seldom be much difficulty in determining the species, especially if the plant is taken while in blossom. Indeed, it will often be possible. to arrive at a conclusion from an inspection of a fer of the more erident cliaracters.

I shall limit myself mainly to a deccription of those species which it may be for the interest of the farmer to cultivate, or at least to encourage in his pastures, with such others as should be known to be aroided.

In the arrangement of species I shall follow mainly the natural order adopted by Professor Gray, to whom, as well as to many others, I am indelsted for no small assistance, in studying the specific characteristies of many of the specimens collected and presented in the following pages.

The reader will find that a frequent reference to figures 1, 2, 3,4 and 5 will greatly aid him in becoming familiar with the technical terms applied to the organs or parts of the flower which it is desirable to understand, and by means of which he will soon learn to distinguish the different species more readily.

In giring the scientific names, the first word that oceurs in 
parenthesis is the name of the genus; the second, that of the species; as for instance, in Herds-grass, (phleum pratense,) phleum is the generic name, pratense the specific. A genus often contains many species.

The grasses which are described more or less minutely in the following pages, are named in

\section{Table I. List of Grasses and Forage Plants.}

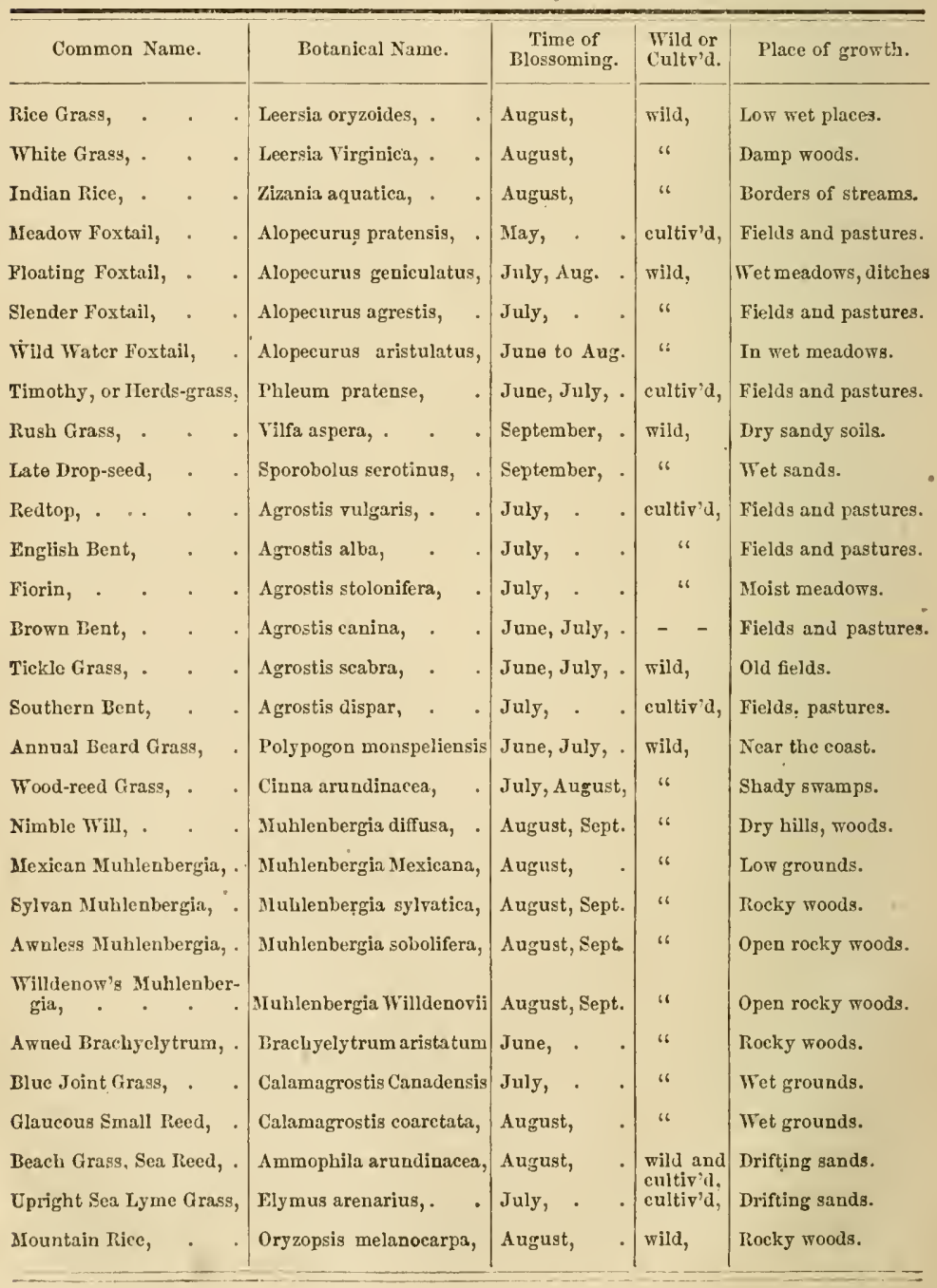




\section{Table I.-Continued.}

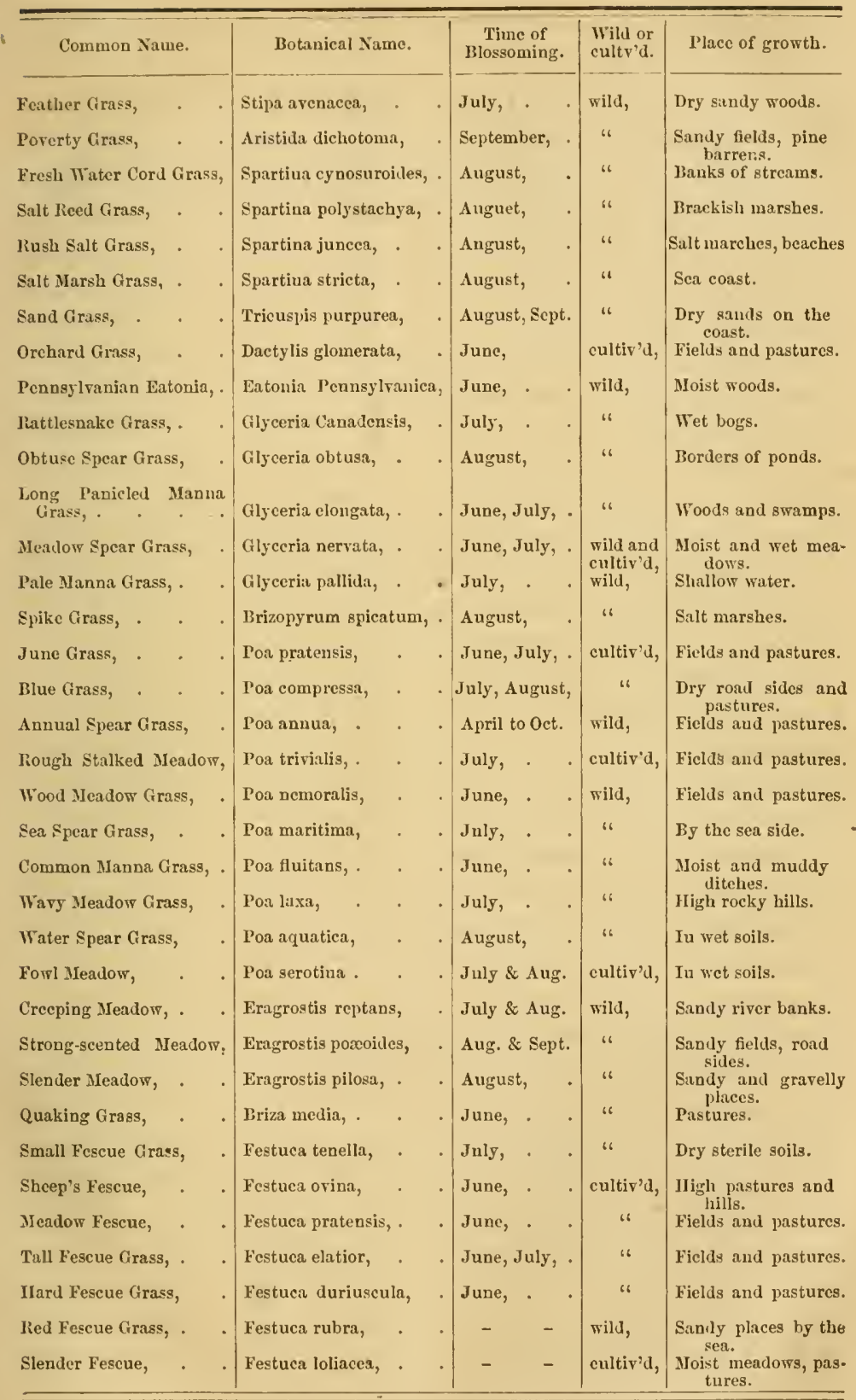




\section{Thabe I.-Continued.}

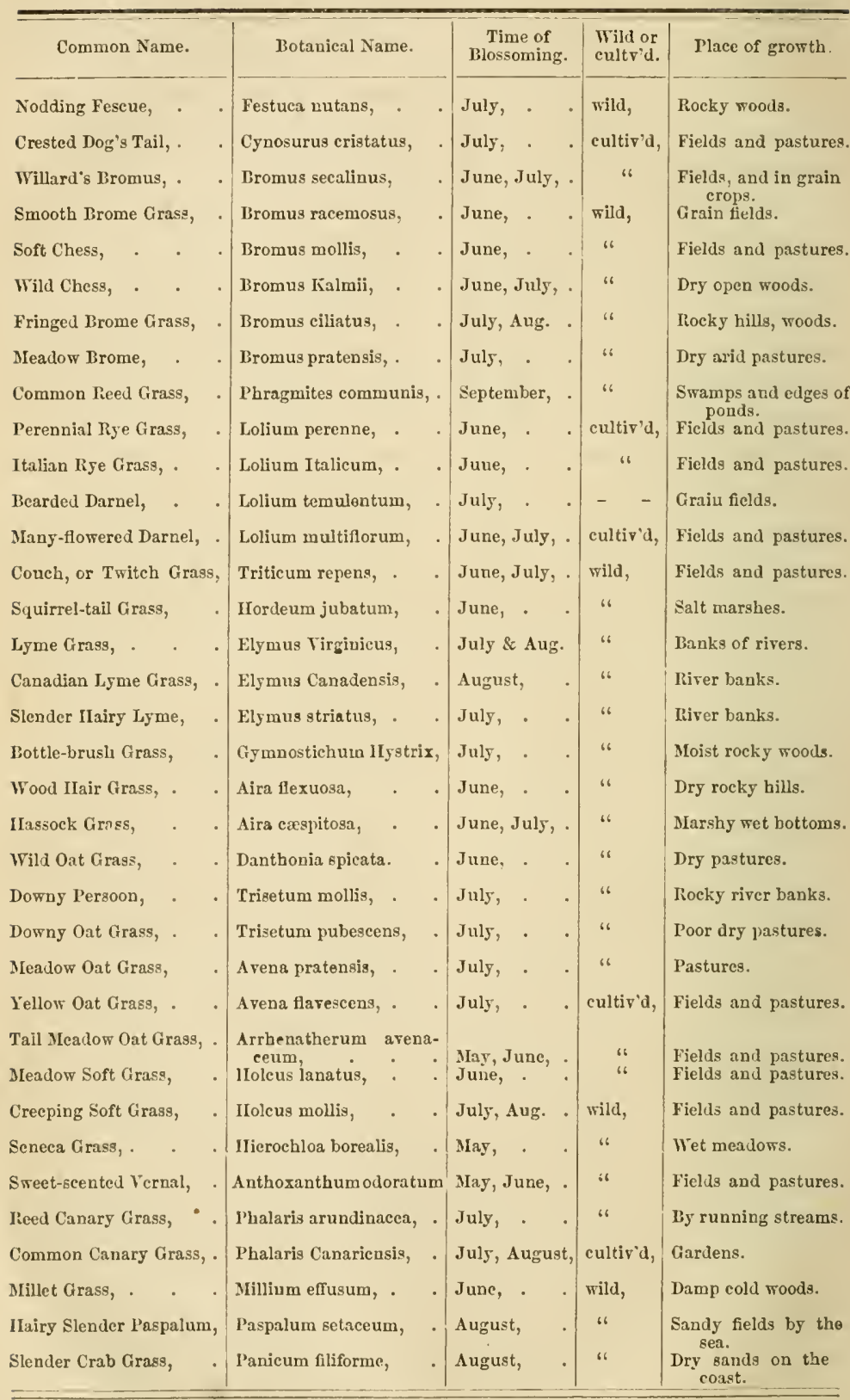




\section{Table I.-Continued.}

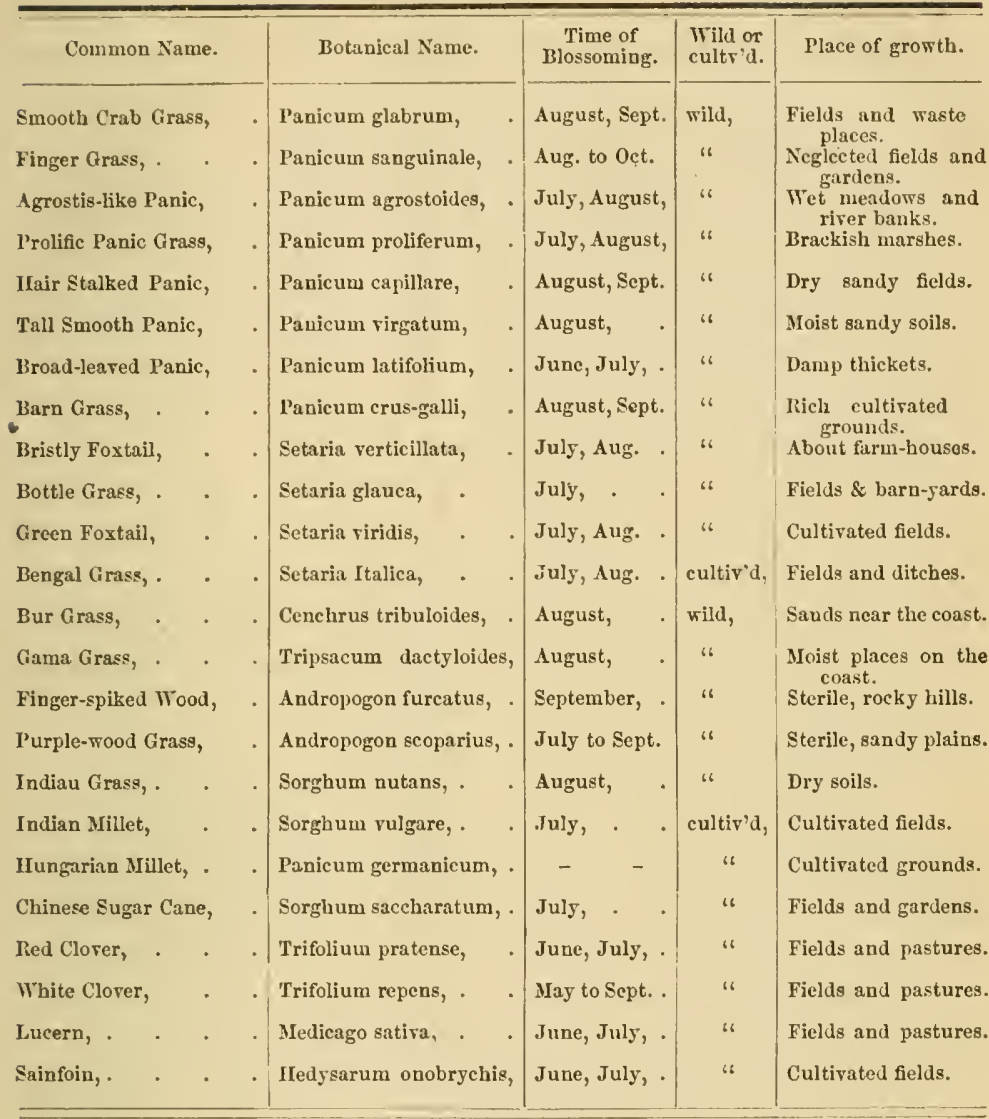

Rice Grass, Cut Grass, False Rice, (Leersia oryzoides,) grows very common in wet swampy places. Stems from two to three feet high, panicle ereet, spreading with rough, slender branches, leaves narrow or long, sheaths exceedingly rough and sharp to the hand, drawn from the end backward. Florets oral and white, spikelets flat. Flowers in August. Native of the Lerant. Name from Leers, a German botanist.

It is a beautiful grass, said to be useful at the South, where it is eultivated to some extent, and may be cut sereral times in a season. It is said there to make a valuable hay. Here it is regarded as a weed, and thorough draining will destroy it. The 
fine specimens of this grass in the State cabinet, were obtained at Westhorough.

White Grass, Virginian Cut Grass, (Leersia virginica,) is rather smoother than the preeding; panicle oblong, spiked, flowers considerably smaller-white; found in damp woods. Flowers in August. Native of North America.

Indian Rice, or Water OATs, (zizania aquatica,) is also found in swampy borders of streams, in shallow water, and on the borders of ponds, and is common. It grows from three to nine feet in height, with flat, long, lanceolate leares. Flowers in August, and drops its seed, when ripe, at the slightest tonch. This furnishes food for water fowls, and was also used by the aborigines for food. Native of North America.

Meadow Foxtall, (alopecurus pratensis.) Generic characteristies: Spikelets, one flowered, glumes compressed and keeled, united at the base, lower palea awned on the back, upper palea wanting, stamens three, styles generally united, stigmas long, panicle compressed into a eylindrical spike like the tail of a fox, from which it derives its name. Native of Great Britain.

The specific characters are, an erect, smooth stem, two or three feet high, with swelling sheaths, spikes cylindrical, obtuse, equalling the sharp cone-like glumes, awn twisted and twice the length of the blossom. The spike not so long as that of Timothy. Flowers in May, in fields and pastures. Perennial-introduced. Fig. 6 shows the root, stem or culm, and spike of this grass, and Fig. 7 the blossom somewhat magnified.

The meadow foxtail closely resembles Herds-grass, but may be distinguished from it as having one palea only. The spike or head of meadow foxtail is soft, while that of Timothy or Herds-grass is rough. It flowers earlier than Timothy, and thrives on all soils except the dryest sands and gravels. It is common in some sections of this State, as the western part of Worcester County, where it is disliked by many famers as a field grass, being very light in proportion to its bulk.

It is a ralualle grass for pastures, on account of its early and rapid growth, and of its being greatly relished by stock of all kinds. The stems and leaves are too few and light to make it so desirable as a field crop. It thrives best on a rich, moist, strong soil, and the quantity of its nutritive matter when 


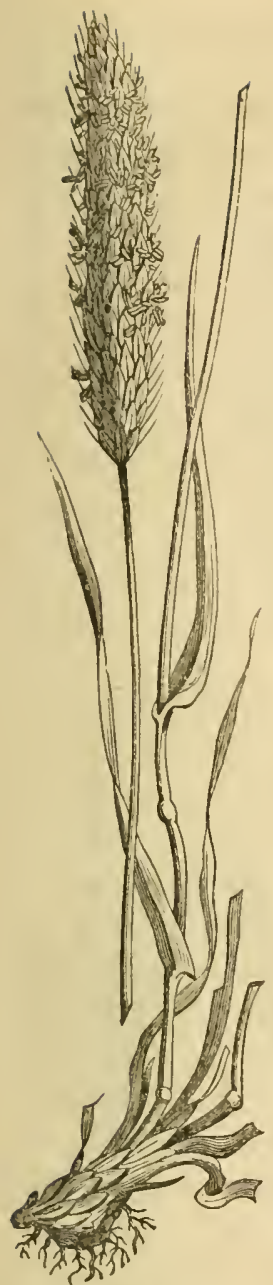

Fig. 6. Meadow Foxtail

raised on such soils is considerably greater than on sandy soils. As a pasture grass, its huxuriant aftermath, being in value nearly one-fourth greater than its first spring growth, recommends it still more highly. In this respect it is superior to 'Timothy, the aftermath of which is generally but slight. For lands designed to be laid down to permanent pasture it will make a prominent part of the seed. Where it occurs in fields, it loses largely its nutritive value if cut in the blossom. It is regarded in England as one of the most raluable of the native pasture grasses, forming there a very considerable portion of the sward, regetating with great luxuriance, and starting up rigorously when eaten off

Fir. 7 . by stock, producing seed in abundance, and enduring any amount of forcing and irrigation. It does not aequire its full perfection and hold of the soil until three or four years after being sown. The aftermath exceeds the flowering erop in quantity as well as in nutritive matter. The grass loses serenty per cent. of its weight in drying, and the hay contains about sixty-seven hundredths per cent. of nitrogen.

The seed of meadow foxtail is covered with the husks of the flower, soft and woolly, while the larger valve is furnished with an awn. There are five pounds of seed in a bushel, and 76,000 seeds in an ounce. An insect attacks the seed while it is forming, and it is also sulject to blight, and hence the seed is somewhat difficult to procure and is held at a high price. We have many grasses superior to it for cultiration, but for permanent 
pastures it is superior to Timothy, which is not a suitable pasture grass.

Slender Foxtall, (alopecurus agrestis.) (Fig. 8.) This grass is rarcly found here, never, indeed, except when intro-

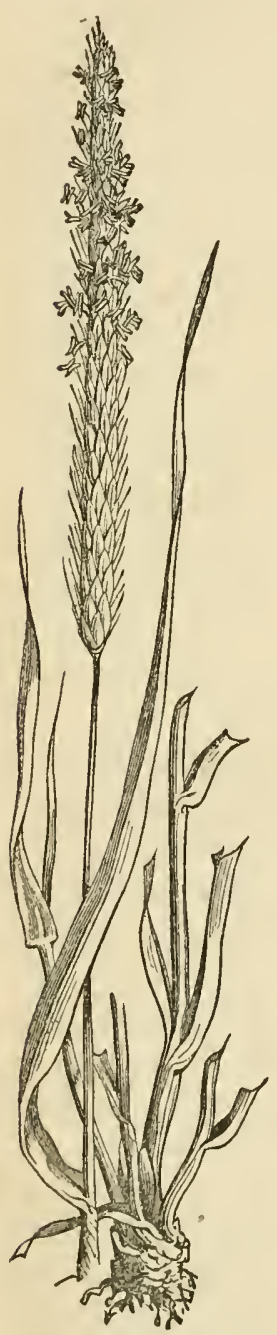

Fig. 8. Slender Foxtail.
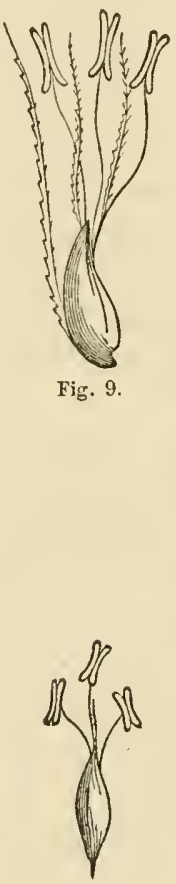

Fig. 10.

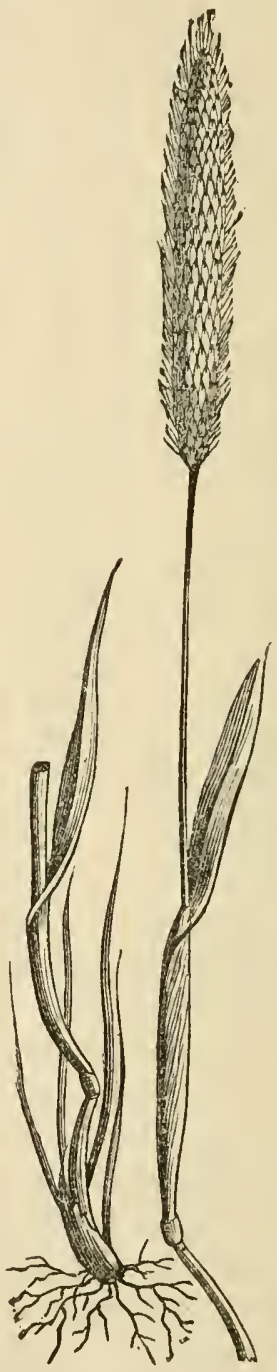

Fig. 11. Floating Foxtail.

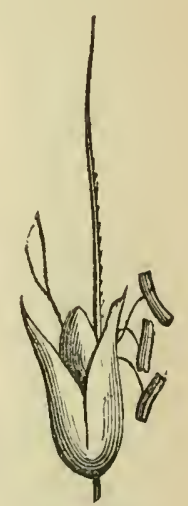

Fig. 19

duced in foreign seed, and therefore, scarcely deserves a detailed description. It is recognized by its long, slender panicle, tapering at each end, and the long awn which projects far beyond 
the palea, (Figs. 9 and 10.) It is distinguished from the common meadow foxtail by its slender paniele, its larger spikelets, its larger ligule and the roughness of the stem and leaves. It possesses no particular agricultural value. Flowers in July. Annual. Native of Great Britain.

Flontrycr Foxtur, (alopecurus geniculatus.) Stem ascending, bent and forming knees at the lower joints, as shown in Fig. 11; awn projecting beyond the palea, (Fig. 12,) which is rather shorter than the obtuse grtumes; anthers linear, upper leaf as long as its sheath; root perennial, fibrous, joints smooth, long and narrow, of a purple tinge ; leares flat, sharp, roughish on both sides, serrated on the edge. Inflorescence simple panicled; spikelets numcrous, eompressed, erect, with a one awned floret as large as the calyx. Floret of one palea, awn slender. Found in moist meadows, ditehes, ponds and slow streams, floating on the water. It is distinguished from mendow fortail in liaving the upper sheath about the length of its leaf, and by the projecting awn, while in the meadow foxtail the upper sheath is more than twice the length of its leaf. Flowers in July and August.

It is a grass not much relished by stock of any kind, while it yiclds but a small amount of herbage.

The Wild Water Foxtail, (alopocurus aristulatus,) also grows in wet meadows, but is of no special agricultural value. Native of Great Britain.

Timothy, or Herds-grass, (phleum pratense.) Generic characters: Panicle spiked, spikelets compressed, palea shorter than the awned glumes, the lower one truncate, usually awnless; styles distinet, filaments hairy, spike dense, rough, or harsh. So called from an ancient Greek term signifying cat's tail, the name by which it is still most frequently known in Great Britain.

Specific characteristics: Spikes cylindrical or elongated; glumes hairy on the back, tipped with a Iristle less than half their length leaves long, flat, rough, with long sheaths; root fibrous, often bulbous-peremial. Grows best on moist, peaty soils. (Fig. 13.) In Fig. 14 is seen a flower somewhat magnified. 'This grass-universally known and highly valued among the farmers of New England-is said to have received its name more than a century and a half ago from one Herd, of Piscataqua, who is said to lave found it growing in a swamp there. 
The name of Timothy, by which it is more generally known over the country and abroad, was obtained from Timothy Hanson, who eultivated it extensively, and according to some accounts, introduced it into England, from whence it is supposed to lave been origimally brought to this country. It forms a large proportion of what is called English hay. In point of nutritive matter, Sinclain says, the ripe erop greatly exceeds the crop at the time of flowering. If this is so, it is owing in part to the size and quantity of its mealy seeds. As many as thirty bushels, of fortysix pounds to the bushel, have been obtained to the acre.

The results olstained by Prof. Way will be found on a subsequent page in the discussion upon the mutritive values of the various grasses. It may be remarked, in passing, that there are many considerations to determine the time of eutting and curing grass, besides its nutritive value at different stages of its growth, as its palatability

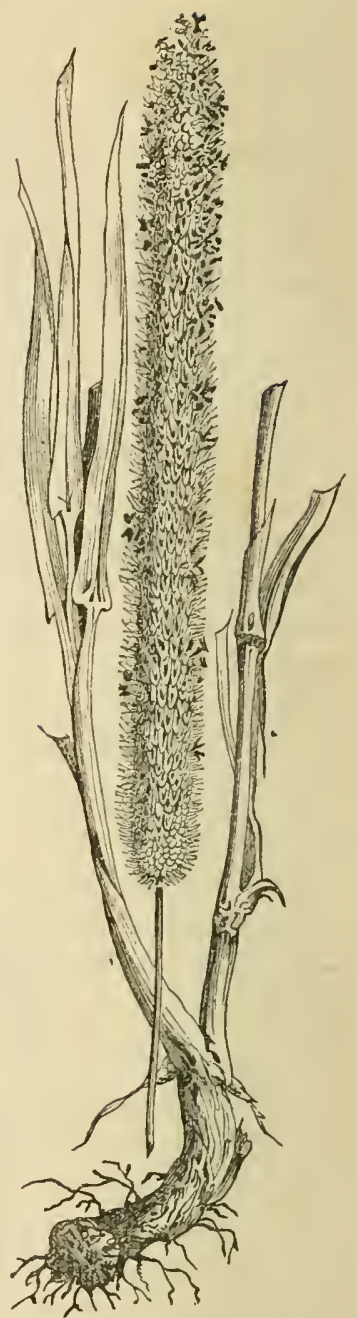

Fig. 13. Timothy, or Herds-grass. at the time of blossoming, and the greater growth of aftermath which is lost by allowing the grass to ripen. This subject will form the topic of a subsequent section.

$\Lambda$ s a crop to cut for hay it is probably musurpassed by any other grass now cultivated. Though somewhat coarse and hard,-especially if allowed to ripen its seed, yet if cut in the blossom, or directly after, it is greatly relished by all kinds of stock, and especially so by horses, while it possesses a large per- 
centage of nutritive matter in comparison with other agricultural grasses. It is often sown with clover, but the best practical farmers are beginning to discontinue this practice, on account of the different times of blossoming of the two crops. Timothy being invaribly later than clover, the former must be cut too green, before blossoming, when the loss is great by shrinkage, and when the mutritive matter is considerably less than at a little later period, or the clover must stand too long, when there is an equally serious loss of nutritious matter in that. It thrives best on moist, peaty or loamy soils of medium tenacity, and is not suited to sandy or light gravelly lands; for though on such soils, by great care it can be made to grow and produce fair crops, some other grasses are better suited to them and more profitable. It grows very readily and yields very large crops on favorable soils. I have known instances where its yield was four tons to the acre of the best quality of hay, the Timothy constituting the bulk of the grass. It is cultirated with case, and yiclds a large quantity of seed to the acre, varying from ten to thirty bushels on rich soils.

In one respect, perhaps, it must be admitted that this grass is inferior to meadow foxtail, and that is in the quantity of its aftermath; for while that of the latter is very great, the aftergrowth of Timothy is but slight, and if allowed to stand too long and then mown in a dry time, it starts so slowly as to leave the ground exposed to the scorching rays of the sun, unless indeed there happens to be a rapid growth of clover to protect it. The comparative value of this grass will be referred to hereafter. It is proper to say in this connection that it is frequently attacked by an insect apparently just before the time of blossoming, which eauses the stalk to die. The rarages of this insect seem to lave increased within the last few years. My attention has been repeatedly called, by observing and practical farmers, during the last few months, to the very large number of dead Herds-grass stalks.

Rush Grass, or Roughi Leaved Vilfa, (vilfa aspera,) and Hidden Flowered Vilfa, (vilfa vaginaflora, are sometimes found here; the former, rarely on diry hills and sandy fields, or pinc plains; the latter, somewhat more frequently on similar soils and situations, both flowering in September, and neither considered of any value for cultivation. The Late 
Flowerisg Vilfa, (vilfa serotina, is somewhat common in sandy swamps. It is a rery delicate grass, flowering at the same time with the preceding.

Late Drop Seed, (sporobolus serotinus,) is sometimes found in low, swampy places, with smooth, slender, flatish stems, leares few and slender, panicle spreading, with hairy branches, glumes orate, obtuse and half the length of the palea. Flowers in September. It is a delicate grass of no special agrieultural value.

Redtop, Finetop, Burdex's Grass, Dew Grass, Herds-Grass of Pennsylvania and Southern States, (agrostis vulgaris,) Fig. 15. Plants of this genus have one flowered spikelets in a loose open panicle; glumes nearly equal, the lower longer than the paler, which are thin and naked; stamens three-perennial.

The specifie eharacters are, stems erect, slender, round, smooth and polisleed; roots creeping, panicle oblong, leares linear, ligule very short, lower palea mostly awnless and three nerred. Flowers in July. Pastures and moist meadows very common-introduced. The term agrostis was the ancient Greek word for field, and was applied to all rarieties of grass that grew there.

This raluable grass, so common in all cur cultirated fields, las been an inhabitant of our soils for more than a century. It was called simply English grass by Eliot, Deane and other early writers, and by the English, Fine Bent. Indeed, the whole genus agrostis is commonly known in England as "Bent Grass." This grass is often sown with Timothy and clover, in which case, the elorer, of course, soon disappears, being biennial, when Timothy follows, after which redtop usually takes its place, and with some wild grasses forms a close sward. In Pennsylrania and States further sonth, it is universally known as Herds-grass-a name applied in New England and New York to phleum pratense alone. It is of somewhat slow growt $l_{1}$, but of good or medium quality. It is suited to moist soils, though common to all. This grass is probably rather orerrated by us. It makes a profitable crop for spending, though not so large a crop is obtained as from.Herds-grass. It is a good permanent grass, and consequently well suited to our pastures, standing our elimate as well as any other grass. It should be fed elose in pastures, for if allowed to grow up to 


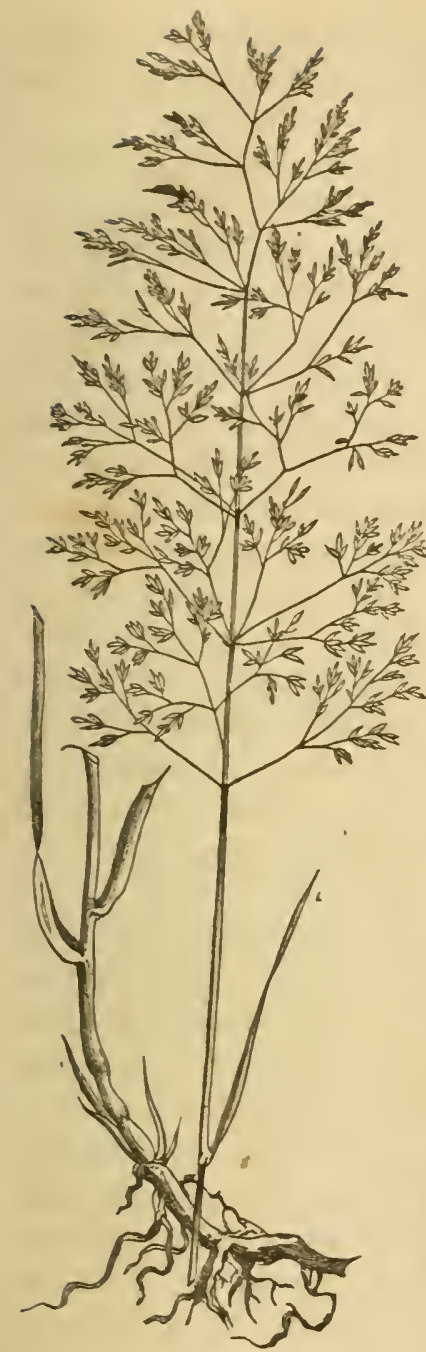

Fig. 15. Redtop.

seed the cattle refuse it; and this fact seems to show that it is not so much relished by stock as some of the other pasture grasses. 'The fact that cattle eat any grass greedily in the spring, is no proof of its excellence or nutritious qualities; since, then, all grasses are tender and full of juice, and many raricties of both grasses and shrubs are readily eaten, which at a more adranced stage of growth are refused. It is to be regretted that Prof. Way, in his raluable investigations into the nutritive ralue of the grasses, did not include this in the list analyzed by him. At present we have no accurate and reliable means of comparison of this with other species of grass. The flower of the true redtop is seen magnified in Fig. 16.

This grass goes by rarious names, and is greatly modified by soil and cultiration. On a moist, rich soil it grows larger than on a poor, thin

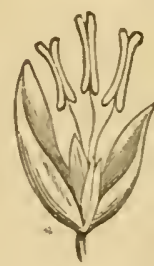

Fig. 16. poor, grarelly soils, it sel-

dom grows over trrelve inches, and often not over five or six inches high, while it has a lighter color. In the latter situations it goes by the name of Finetop, and is unirersally seen in old, dry pastures. In some sections of the State, as in Bristol County, it goes by the name of Burden's or Borden's grass, or Rhode Island Bent, and is highly esteemed.

Finetop may be regarded as a rariety of redtop, produced by the character of the soil. 
Dew Grass, White Top, White Bent, Exglish Bent, Boxiet Grass, (agrostis alba.) Generic characters same as those of redtop.

Specific characters: Stem erect, round, smooth, polished, haring four or fire leares with roughish sheaths, striated, upper sheath longer than its leaf, crowned with a long, acute, ragged ligule; joints smooth, branches numerous, recumbent, rooting at the lower joints where they come in contact with the gromud, as in Fig. 17; panicle somewhat narrower than in redtop, lightish green, or with a slight tinge of purple; lower or inmer palea onc-lialf the length of the upper, and shorter than the glumes; fire nerved, awnless-perennial. Native of Europe.

White top may be known from redtop by the sheaths being rough to the touch from above downwards, and the ligule being long and acute, and the keel of the large glume of the calyx toothed nearly to the base. In agrostis vulgaris the sheaths are smooth, ligule short and obtuse, and the keel of the large glume toothed only on the upper part.

It may be known from Brown Bent, (agrostis canina,) by having an inner palea in its floret, while in brown bent the inner palea is wanting. This grass is rery common on the Comnecticut River meadows where it appears to be indigenous, and is there called the English bent. Fons, (agrostis stolonifera,) is only a variety of the white top, or agrostis alba, which gained great notoriety some years ago in Ireland and England, volumes having been written in its praise, while it received the execrations of those who found it troublesome to eradicate on account of its creeping and stoloniferous roots. This grass belongs peculiarly to moist places which are occasionally overflowed. Fig. 17 represents it, and Fig. 18, a magnified flower. This grass is often used in the manufacture of bonnets. It is called Dew grass in some sections.

Brow Bext, ol Dog's Bext Grass, (agrostis canina,) another varicty of agrostis, has for its specific characters, a floret of one palea, sheaths smooth, ligule long, and grows from one to two feet high, awnless. The root is percunial and creeping. The stem is erect, slender, leaves flat and linear. The palea shorter than the glume and furnished with a long awn on the back, bent; spikelets at first greenish, afterwards brown or slightly purple. Meadows and pastures, and wet, peaty 


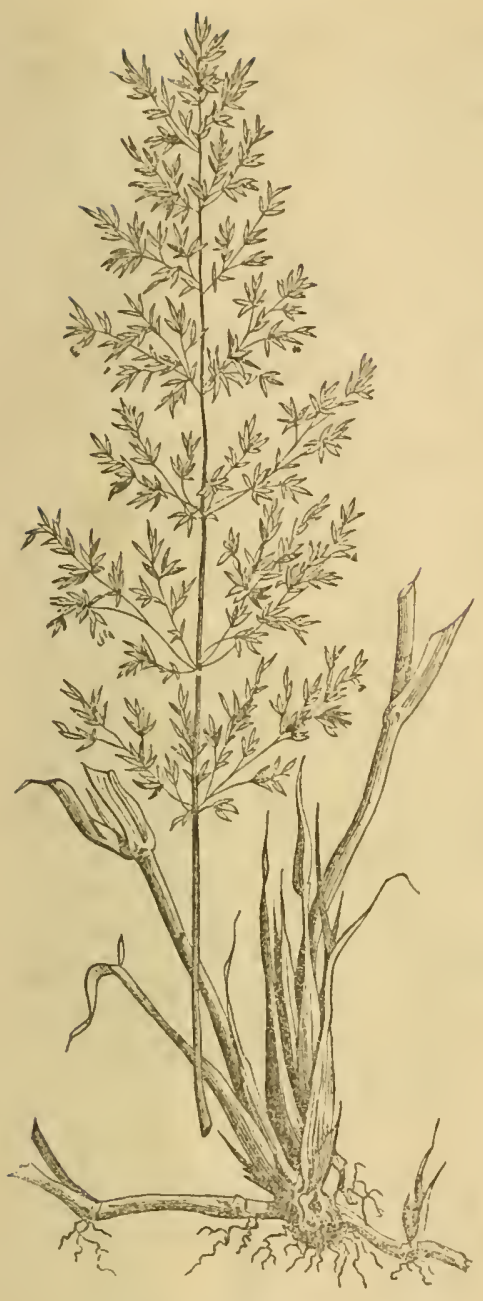

Fig. 1i. Euglish Bent.

places-introdued. Flowers in June and July. It is of no special agricultural value.

Hair Grass, or Fly Away Grass, Tickle Grass, (agrostis scabra, ) is another species belonging to this genus, with a panicle very loose and spreading, merplish. Flowers in June and July. Mainly remarkable for the long hairy branclies of its extremely loose panicle. Common in old fields and drained swamps. It is of $n o$ particular agricultural ralue. Very common at the West, in Ohio, Illinois, Michigan, and aljout Lake Superior. The large, loose panicles are exceedingly delicate and brittle when the plant is ripe and dry, and casily break array from the stalk when they are blown about by the wind, seattering their seeds far and wide; and lence it is frequently called "Fly Away Grass."
This illustrates one of
the admirable contriv-
ances of nature for the
distribution of the Fig. 18. seeds of grasses and other plants; sometimes by means of birds, sometimes by a sort of wing attached to the light seed, and sometimes by the force of the wind alone, as in this ease, when plants start up where no seed had been sown by the hand of man, and often to our astonishment.

This Grass, (agrostis perennans,) is still another variety of agrostis, with a panicle diffusely spreading, pale green ; branches short, divided and flower-bearing from or below the middle; found in damp, shaded places. Flowers in June and July. 
The Alpine Brown Bent, the Upright Flowered Bent, and many other species of agrostis might be mentioned. Of all the species of this genus, the redtop and white top are the most common as agricultural grasses among us.

The Fionis, (agrostis alba, var. stolonifera latifolia,) or Broad Leaved Creeping Best, has been more highly commended in Europe than either of these. In the Woburn experiments which will be alluded to, this last was found to be inferior in nutritive value to orchard grass and meadow fescue, (festuca pratensis, ) and superior to meadow foxtail (alopecurus pratensis.)

The Southerv BeNT, (agrostis dispar,) (Fig. 19,) has been highly extolled in France. It is a native of the United States; was at one time highly commended in England, but was very soon discarded. It furnishes a hay of rather coarse quality, yields a large produce on good, deep sands and calcareous soils. It tillers very much, and when once rooted is very vigorous and lasting, and consequently makes a good pasture grass. It is very similar in Fig. 20 . appearance to some

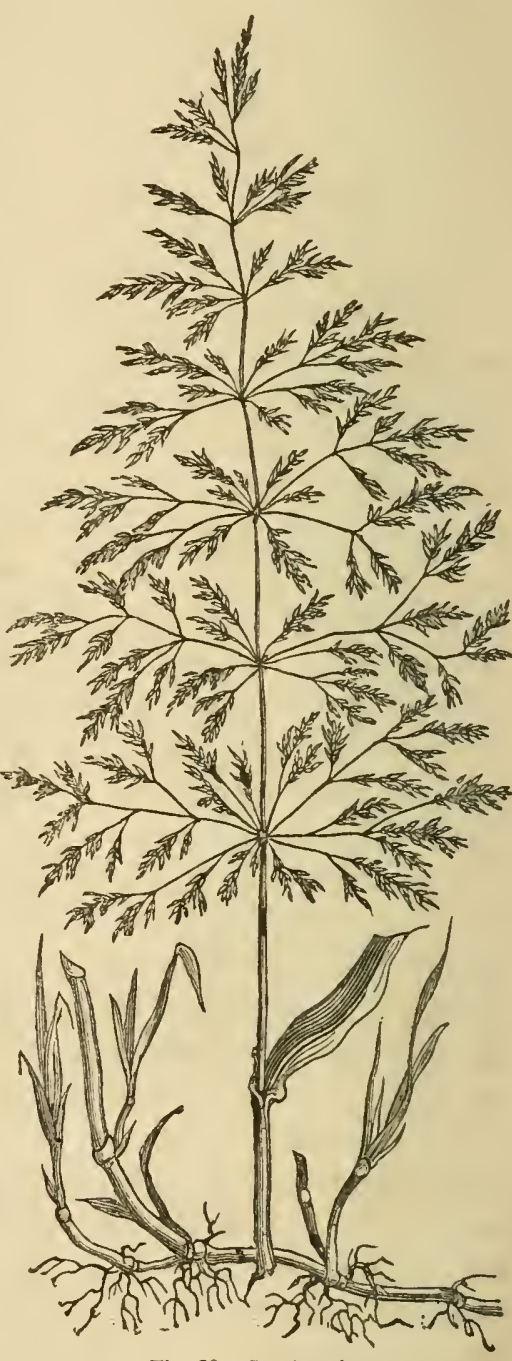

Fig. 19. Southern!̣iBent. of the broad leaved varieties of agrostis vulgaris, and is said to yield a larger produce than that commonly known as redtop. It has stronger and more numerous creeping roots, 
broader leaves and more upright leafy stems. It is most froquently met with in the Southern States and in the south of France. Fig. 20 represents the flower of this grass magnified.

Axnual Benard Grass, (polypogon monspeliensis,) is a grass which is oceasionally found near the eoast. It may be known by haring glumes with awns more than twice their length, growing from ten to fifteen inches high; stem erect, round, and a little rougl ; fire or six leares, flat, rather broad and acute; panicle dense, spikelets one flowered-introduced. It is easily distinguished from other grasses by the length of its awns or beards. Of no agricultural value.

Wood Reed Grass, Indian Reed, Reedy Cinsa, (cinna amundinacea,) lias spikelets, one flowered, feathered; glumes lanceolate, acute, strongly keeled, palea like the glumes, short awned-perennial; stems erect and reed-like, three or four feet high. The spikelets are green, or of a slight purplish tinge. Moist woods and swamps, common. Flowers in July and August. Panicle large, hairy, rather dense. A large, rank grass, differing from others in having but one stamen in each flower. Of no special agricultural value.

Drop Seed Grass, (Muhlenbergia diffusa,) is a grass which derives its generic name from Dr. Henry M[ullenberg, a distinguished American botanist, pupil of the great Linnæus. It is commonly known in Kentucky and Tenmessee by the name of "Nimble-will," and there forms a pasture grass of some value. Its stems are diffusely branched, from ten to eighteen inches high; panieles slender, contracted, glumes minute, awn nearly twice as long as the palca. It is sometimes found on dry hills and in woods. Flowers in August and Septemberperemial. Cattle eat it very readily. Not very common.

There is another species of this grass, the Muhlenbergia glomerata, from one to two feet high, much more common than the preceding, with stems upright, somewhat branched; panicle oblong, linear, contracted into an interrupted glomerate spike, with long peduncles or flower stalks and awned glumes-perennial. Flowers in August and September. Common in swamps and low grounds. Of no agricultural value.

The Erect Muhlenbergia, or Awned Brachyelytrum, (Muhlenbergia erecta,) is often found in rocky woods, on the sides of Wachuset Mountain, and many other similar situations. 
It is a simple, slender grass, two or three feet high; flowers few, root perennial, creeping, sheaths downy, leares broad and flat, lanceolate, pointed. Flowers in June.

The Mexican Muhlexbergia, (Muhlenbergia Mexicana,) another species of this genus, has been mistaken by some for our fowl meadow. It has an erect stem, two to three feet high, much branched; panicles lateral and contracted, branches densely spiked and clustered, green or purplish; glumes pointed, awnless and unequal. It is peremial. Flowers in August. Frequently regarded as a troublesome weed in low grounds; somewhat common at the West and frequent here in low grounds, the borders of fields, and even in gardens, where its spreading roots are difficult to eradicate. Cattle eat it very readily, and as it blossoms late in the season, it is of some value.

Thio Silvan Muhlenbergia, (Muhlenbergia sylvatica,) is also rather common in low, rocky woods. Its stem is ascending, branched, spreading diffusely; panicles contracted, densely flowered; glumes nearly equal, bristle pointed, lower palca one awned, twice or three times the length of the spikelets. Flowers in August and September.

The Awnless Muilexbengia, (Muhlenbergia sobolifera,) is sometimes found in open, rocky woods, from New England to Michigan, and farther south. It grows from one to two feet high, with a simple contracted panicle, very slender; glumes long, pointed, nearly equal, root perennial, creeping, woody, leaves pale green, sheaths open, ligule wanting. Flowers in Angust and September.

Still another species, sometimes called Hair Grass, (Muthlenbergia capillaris,) is sometimes, though not often found on sandy soils.

Whlldenow's Munlenberais, (Muhlenbergia Willdenovii,) is also not uncommon in rocky woods, growing about three feet high, with a slender, simple stem, contracted panicle, loosely flowered, glumes sharp pointed, half as long as the lower palea, which has an awn from three to four times the length of the spikelet.

None of the grasses of this American genus are of great value as agricultural grasses, except as they add considerably to the mass of living verdure which clothes our low lands in 
beauty to delight the eye and swell the heart of the lover of nature.

Buve Jonte Griss, (calamagrostis canadensis.) 'The generic clraracteristics are, one flowered spikelets, open panicle, contracted or spiked; glumes keeled, abont equal to the palex, aromml which, at the base, is a thick tuft of white bristly hairs; lower palea generally with a slender awn on the back.

Specific description: Stems three to fire feet high, greyish, leaves flat, panicle often purplish, the glumes acute, lanceolate, lower palea not longer than the very finc hairs bearing an cxtremely delicate awn below the middle, nearly equal to the hairs. Flowers in July. The blue joint grass is rery common on low grounds. It is generally considered a valual,le grass. It is eaten greclily by stock in the winter, and is thought by some to be as nutritious as 'Timothy.

The Guaucous Salule Reed, (calamagrostis roarctata,) is also somewhat common in our wet mealows, open swamps and along low river banks. Its stems are from three to five feet high, seed hairy, crowned with a bearded tuft; lower palea shorter than the taper-pointed tips of the lanceolate glumes, almost twice the lengtl of the hairs, with a rigid, short awn above the middle.

Beach Grass, Sea Saxd Reed, Mat Grass, (ammoplila arundinacea,) grows to a lieight of two or three fect, with a rigid culm, from stout roots ruming often to the distance of twenty or thirty feet; leares wide, rather short, of a sea green color; panicle contracted into a close, dense spike, from six to twelvo inches long, nearly white. It is found in the sands of the sea shore where its thick, strong, creeping, perennial roots, with many tubers the size of a pea, prevent the drifting of the sand from the action of the winds and wares, thus forming a barrier against the encroachments of the sea.

This grass is very generally diffused on sea coasts over the world, and is found inland on the shores of Lake Superior. It has also been cultivated by way of experiment, and with suceess, on the sands at Lowell, and still farther up on the banks of the Merrimack River. Though not cultivated for agricultural purposes, it is of great ralue in protecting sandy beaches. It is preserved in England and Scotland by act of parliament. Flowers in August. 
In the year 1853, I was requested by the late T. W. Harris, to make this grass a special study in the course of my observations, and since that time I have tried in every way, by personal inquiries and by correspondence, to collect whatever there might be of interest in relation to it.

The torn of Provincetown, once called Cape Cod, where the Pilgrims first landed, and its harbor, still called the harbor of Cape Cod,--one of the best and most important in the United States,-sufficient in depth for ships of the largest size, and in extent, to anchor three thousand ressels at once, owe their preserration to this grass. 'To an inhabitant of an inland country, it is difficult to conceire the extent and the riolence with which the sands at the extremity of Cape Cod are thrown up from the depths of the sea, and left on the beach in thousands of tons by erery driring storm. These sand hills when dried by the sum are hurled by the winds into the harbor and upon the town. A correspondent at Provincetown says: "Beach grass is said to hare been cultivated here as early as 1812. Before that time, when the sand drifted down upon the dwelling-houses, - as it did whenever the beach was broken,to sare them from burial the only resort was to wheeling it off with barrows. Thus tons were remored erery year from places that are now perfectly secure from the drifting of sand. Indeed, were it not for the window glass in some of the oldest houses in these localities, you would be ready to deny this statement, but the sand has been blown with such force, and so long against this gla.s as to make it perfectly ground. I know of somo windorss through which you camnot see an object, except to remind you of that passage where men were seen 'as trees walking." "

Congress appropriated, between the years 1826 and 1839 , about twenty-cight thonsand dollars, which were expended in setting out beach grass back of the village, for the protection of the harbor. From the seed of this grass it is estimated that nearly as much ground has become planted with it as was covered by the general govermment. In 1854 , fire thousand dollars were expended most wisely by the general gorernment in adding to the work so molly hegm ; and the experience of former years was of great value to the effieiency of this latter effort. The work of fortification or protection is not yet com- 
plete. The castem part of the harloor is much exposed to injury from the sand which now empties itself loy the thousand tons every north wind, into the east harbor. Unless there is speedily another appropriation from concress, to be applied in the direction of East Harbor, it is easy to foretel the fearful consequences to it.

"It may be proper to state," says the same writer, "that this town does much in the way of 'beach grassing, by its 'beach grass committee,' whose duty it is to enter any man's enclosure, summer or winter, and set out grass, if the sand is uncovered and morable. By this means we are now rid of sand storms, which were once the terror of the place, being something like snow storms, for drifts which were to be remored. Our streets are now hardened with clay which has been imported, and instead of its being buried, as it would once have been in a few days, I notice that the surveyors have to resort to sprinkling it with sand in wet weather, so effectually lias the eulture of beach grass answered its end.

"The mode of culture is very simple. The grass is pulled up by hand and placed in a hole about a foot decp, and the sand pressed down about it. These holes are dug about one foot and a half apart. 'The spring is the usual time of planting, though many do this work in the fall or winter. The roots of the grass from which it soon corers the ground, are rery long. I have noticed thom ten feet, and I suppose upon high hills they extend down into wet sand."

Many years ago the beach which comnects Truro and Provincetown was hroken orer, and a considerable body of it swept away. Beach grass was immediately planted, and the beach was thus raised to sufficient height, and in some placos into hills. The operation of it is like that of brush or bushes, cut and laid upon the ground, in accumulating snow in a drifting wind. The sand is collecterl around the grass, and as the sand rises, the grass also rises to orertop it, and will continue to grow, no matter how high the sand hill may rise, and this process goes on orer the whole surface of the plantation, and thus many acres have been raised far above their original level.

A committce of the logislature appointed in 185\%, to inquire into the means of preserving Cape Cod Harbor, in speaking of the beach between the ocean on the north, and the channel of 
East Harbor,- -and which is all that prevents the sea from breaking over into Cape Cod Harbor,-say: "This tract consists of loose sand, driven about by every high wind, which throws it up in heaps like snow drifts. The wind, from any point from north-east to north-west, drives the sand directly from said beach into the channel of East Harbor, and is carried by a strong current into the north-east part of Cape Cod Harbor. The ocean on the north is wasting this narrow beach away in every storm, and the current in East Harbor channel undermining and destroying it on the south. The decay of said beach has been on the increase for several years; it has narrowed within seven or eight years, by the tide that runs through East Harbor channel, from eight to ten rods; where the mail stage travelled only one year since, is now the channel, with six feet of water at low tide, and from twelve to fourtecn feet at high water."

The first effort made by the State for the preservation of this important harbor appears to have been in 1714 . The town was incorporated in 1727, and was at that time a place of some extent, but the inhabitants soon began to leave, and in less than twenty years it was reduced to two or three families. After the Revolution the place revived, and is now a thriving town.

The object of the law of 1714 was to arrest the destruction of the trees and shrubbery on the province lands, and on the preservation of which it was thought the harbor depended, as they prevented the drifting of the sand.

In 1824 commissioners were appointed by the State government to examine the sulject and report what action was necessary to prevent the rapid destruction of the harbor. They recommended an act to prevent the destruction of beach grass, and reported that the sum of thirty-six hundred dollars would be necessary to set out that plant, make fences, de. The legislature in 1826 applied to congress for that sum, and congress has, at different times, made appropriations to the amount of about thirty-eight thousand dollars, which seems to have failed in some measure to accomplish the olject intended, and East Harbor is still rapidly filling up.

Many years ago it was as customary to warn the inhabitants of Truro and some other towns on the Cape every spring, to 
turn out to plant beach grass, as it was in the inland towns to turn out and mend the roads. This was required by law, with suitable penalties for its neglect, and took place in $A$ pril.

A farmer of much practical knowledge of this sulyject, says : "Since the eattle have been kept from the beaches, by the act of the legislature of 1826 , the grass and slurubs have sprumg up of their own accord and liare, in a great measure, in the westerly part of the Cape, aceomplished what was intended to be done by planting grass. It is of no use to plant grass on the high parts of the beach. Plant on the lowest parts and they will raise, while the highest places, over which the grass will spread, are levelling by the wind. To preserve the beach it must be kept as level as possible.

"Beach grass is of but little value except to prevent our loose, sandy beaches from being drifted about by the wind. We have but one species, and this is fast spreading orer our upland, making it useless for eultivation. Land that would produce from twenty to twenty-five bushels of Indian eom to the acre, without any manure, twenty-five or thirty years ago, is now overrun with beach grass and will produce nothing clsc. If the dead grass is burnt off in the spring, it will make a pretty good pasture for eattle and liorses. It keeps green longer than any other grass we hare. It can be cultivated from the seed or by transplanting. Our loose, sandy beaches are tlie most suitable for its growth."

Beach grass secms to require the assistance of some disturbing causes to enable it to attain its full perfection. The driving winds in some localities, are sufficient, while in other places, where it does not thrive so well, it is probable that an iron tooth harrow would greatly improve and aid its growtl. It lias been extensively cultivated or propagated from the seed on many parts of Cape Cod, on Nantucket, and in fact to considerable extent all along our coast. It comes in of itself along Nantasket beach from seed borne by the tides, probably, from the Cape. It has been extensively used, at times, in this country, for the manufacture of coarse paper, though if I am rightly informed, its manufacture has been discontinued in this State. In other countries it is manufactured into door mats and brushes, mats for pack-saddles, meal bags and liats, and into ropes for various purposes. 
Motxtary Rice, (oryzopsis melanocarpa,) is a gras ('ommon in rocky wools: the largo white grained mountain : ", (orysopsis asperifolia.) common on steep and rocky hill-irles and dry moods, and the Sirtllest OnIzopsis, (oryzopsis crinadensis,) are sometimes fonnd. The- grasses are easily distinguislied from each other. The first lias an awn thrice the $12 x$ th $^{3}$ of the blackish pal ax; the scoond, an a men two or three tims the longth of the whitish palen; the thirrl. an awn sliort. desiluous or wanting. 'The first grows from two to three feet lighl, the secand from ten to eighteen inches.

Fenther Grass, or Blick O.tT Griss, (stipa avenuce,) is somatimes in st with in dry. sandy wood: and is coll astad for rases and ornaments, lut is of no agrieultural ralue. It rises from one to two feet: its panicle is open. leaves almo:t hristle form, palea blackish, nearly as long as the almost erual glumes, awn bent alove, twisted below. Flowers in July.

Poverty Grass, or Three A Tred Grass, (aristida dichotoma.) and SLENDER ThreE AWNED Griss, (aristira sracilis,) are found in old, sandy fields, dry storile hill-sid:s and pine barrens, but are of no ralue for cultiration. One or two other species of three awned plants also occur on similur soils. as the aristida prrpurascens and the aristida tuberculosa. None of these specis are of importance in agriculture.

Fres H IT Ater Cord Grass. (sparlina cynosuroides.) This is found oil the banks of streams and lakes, rising to the height of from two to four feet, with sender culm, narrow lenves two to four feet long, tapering to a point, and spilices of a straw color. Fluwers in lugust.

THE Silt ReEd Grass, (spartina polystachya.) hn a stout culm frim four to nine feat hich, br ad leares, roumi.h underneath and on the margins: spikes 20 to 50 in mumpr. frrming a druse, oblong, purplish cluster. It is found on the salt marslies.

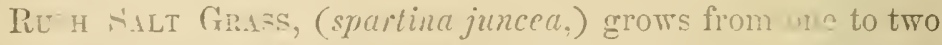

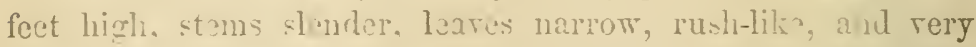
smouth. It is common on salt marshes and sandy a leaches, aud flowars in August.

SALT Mlrish Grasz. (spmilina stricta, rar. gla Jiat.) grows from two to four feet high, has from five to trolie spises from 
two to three inches long; spiliclets crowded and lapping orer each other. It is common on the coast.

SANI) (rRass, (tricuspis mupurea,) is also found on dry. sandy soils, al my the coast; flowering in August and Septemlor. It is acid to the taste, grows from six inches to a foot lighth and has num erous l,earded joints.

Orcham (trass, Rough Cocksfoot, (dactylis s'mmerata.) The gencrie characters are, spikclets sereral flowred, erowded in clustrs, one-sided, paniele dense at the top, branching,

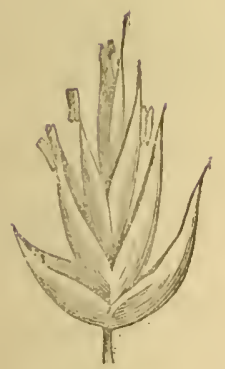

Fig. 22.

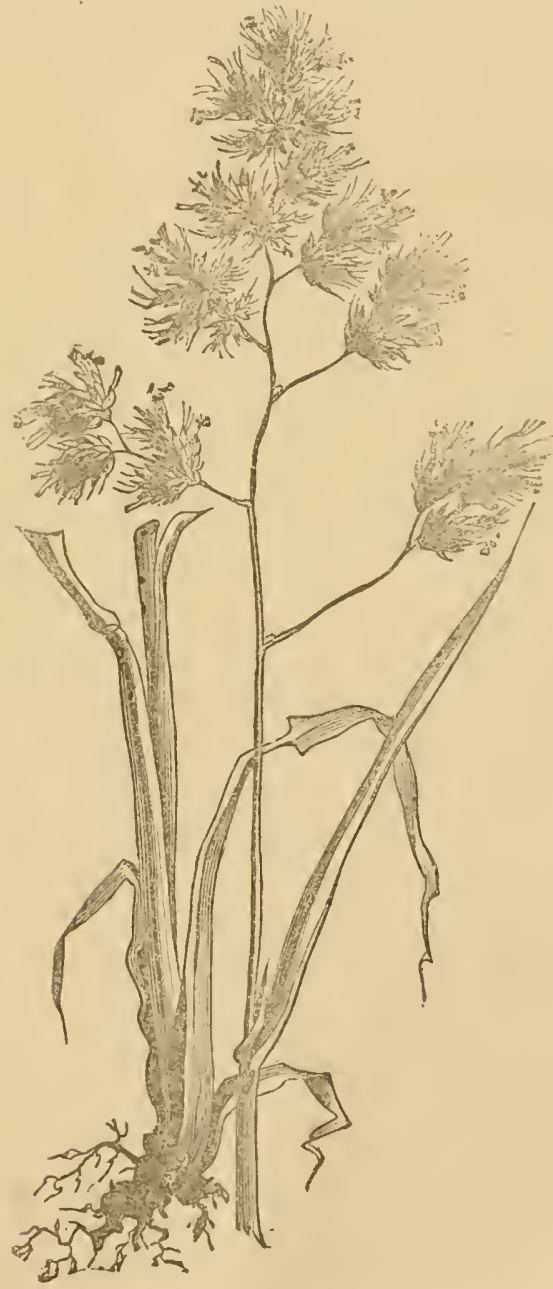

Fig. 21. Orchard Grass. 
glumes tiro, herbaceous, keeled, long-pointed. Stamens three, seed oblong, acute, free. Named from dactylus, a finger.

Orchard grass flowers in dense tufts. Its stem is erect, about three feet high. I have found specimens in good soil, over five fect high. Leares linear, flat, dark green, rough on both surfaces, which, with the fancied resemblance of its loose tufts to the foot of a harnyard fowl, have given it the common name in England of rough eocksfoot. Root perennial. Flowers in June and July. Not uncommon in fields and pastures. It is secn in Fig. 21. A magnified spikelet is shown in Fig. 22.

'This is one of the most valuable and widely known of all the pasture grasses. It is common to every country in Europe, to the north of Africa, and to Asia as well as to America. Its culture was introduced into England from Virginia, where it had been cultivated some years previously, in 176t. It forms one of the most common grasses of English natural pastures, on rich, deep, moist soils. It became, soon after its introdnction into England, an object of special agricultural interest among cattle feeders, laving been found to be excecdingly palatable to stock of all kinds. Its rapidity of growth, the luxuriance of its aftermath and its potrer of enduring the cropping of cattle, commend it highly to the farmer's eare, especially as a pasture grass. As it blossoms carlier than Timothy, and about the time of red elover, it makes an admirable mixture with that plant, to cut in the blossom and cure for hay. As a pasture grass it should be fed close, both to prerent its forming thick tufts and to prevent its rumning to seed, when it loses a large proportion of its nutritive matter, and becomes hard and wiry. All kinds of stock eat it greedily when green.

Judge Buel, distinguished as a man of taste, said of this grass: "I should prefer it to almost every other grass, and cows are very fond of it." Elsewhere he says: "The American Cocksfoot, or Orehard Grass, is one of the most abiding.grasses we have. It is probably better adapted than any other grass to sow with clorer and other seeds for permanent pasture or for hay, as it is fit to cut with elover and grows remarkably quick when cropped hy cattle. Five or six days' growth in summer suffices to give a good bite. Its good properties consist in its early and rapid growth and its resistance of drouth; but all agree that it should be closely cropped. Sheep will pass over 
every other grass to feed upon it. If suffered to grow long without being cropped, it becomes coarse and harsh. Colonel Powell, (a late eminent farmer of Pennsylvania,) after growing it ten years, declares that it produces more pasturage than any other grass he has seen in America. On being fed very close, it has produced good pasture after remaining five days at rest. It is suited to all arable soils. Two bushels of seed are requisite for an acre when sown alone, or half this quantity when sown with clover. The seed is rery light, weighing not more than twelve or fourteen pounds to the bushel. It should be cut early for hay."

Mr. Sanders, a well known practical farmer and cattle breeder, of Kentucky, says of it: "My observation and experience have indueed me to rely mainly on orchard grass and red elover; indeed, I now sow no other sort of grass seed. These grasses mixed, make the best hay of all the grasses for this climate (Kentucky ;) it is nutritious, and well adapted as food for stock. Orehard grass is ready for grazing in the spring ten or twelve days sooner than any other that affords a full bite. When grazed down and the stock turned off, it will be ready for regrazing in less than half the time required for Kentucky blue grass. It stands a serere drought better than any other grass, keeping green and growing when other sorts are dried up; in summer it will grow more in a day than blue grass will in a week. Orehard grass is naturally disposed to form and grow in tussocks. The best preventive is a good preparation of the ground, and a suffieiency of seed uniformly sown. The late Judge Peters of Pennsylvania,-who was at the head of agricultural improrement in that State for many years,-preferred it to all other grasses."

Orehard grass is less exhausting to the soil than rye grass or Timothy. It will endure considerable shade. In a porous subsoil its fibrous roots extend to a great depth. Its habit of growth unfits it for a lawn grass. Its seed weighs twelve pounds to the bushel, and to sow alone, about twenty-four pounds to the acre are required to make sure of a good crop. It should not be sown alone except for the sake of raising the seed. It is worthy of a much more extended cultivation among us.

Penssylfanian Eatonia, (Eatonia Pennsylvanica,) is a grass 
common in moist woods. It has a loose panicle, grows two feet high, with short, flat leaves, of a pale green. Flowers in June.

Rattlessake Grass, (glyceria canadensis.) The generic characteristics of glyceria are, many flowered spikes, mostly flatish ; glumes two pointed, nearly equal, awnless, the lower one obtuse, seven nerved; roots ereeping-peremnial. Wet places and standing water. The name of the genus is from a Greek word signifying sweet.

Rattlesnake grass has an oblong, pyramidal, spreading panicle, with beautifully drooping spikelets, six or eight flowered, and long, roughish leaves, which together make it an object of interest and search for bonquets and rases. It is rery common in wet, boggy places, growing from two to three feet high, but possesses little or no agricultural ralue. Flowers in July.

The Obtuse Spear Grass, (glyceria obtusa,) has a dense, narrowly oblong' paniele; spikelets six or seven flowered, erect, swelling; lower palea obtuse, leares smooth, as long as the stem. This is an aquatic grass, found oceasionally on the borders of ponds. Flowers in August. Of no agricultural value.

Long Panicled Manxa Grass, (glyceria elongata,) is a rery distinet species; stems one to three feet high, panicle branching, narrowly elongated, recurving, the branches appressed, spikelets pale, ereet, three to four flowered, lower palea obtuse, rather longer than the upper; stamens two, stigmas compound, leares very long and rough. Flourishes in wet woods and swamps. Flowers in June and July-perennial. Of no special agricultural value.

Meadow Spear Grass, Nerved Manka Grass, (poa nervata,) is the fowl meadow of some farmers, while the grass most commonly called fowl meadow, (poa serotina,) goes with them under the name of bastard fowl meadow. It has a broad, open panicle, six inches in length, with slender branches; spikelets small, ovate, oblong, green; leares in two rows like a fan, a little rough; stem a little compressed, one to three feet high. It is a native American grass, flowering late in June. The nutritive value of this grass, according to Sinclair, is equal at the time of flowering and when the seed is ripe, while the nutritive matter of the lattermath is said to be greater than that of most other grasses. It is a hardy grass, grows best on wet or 


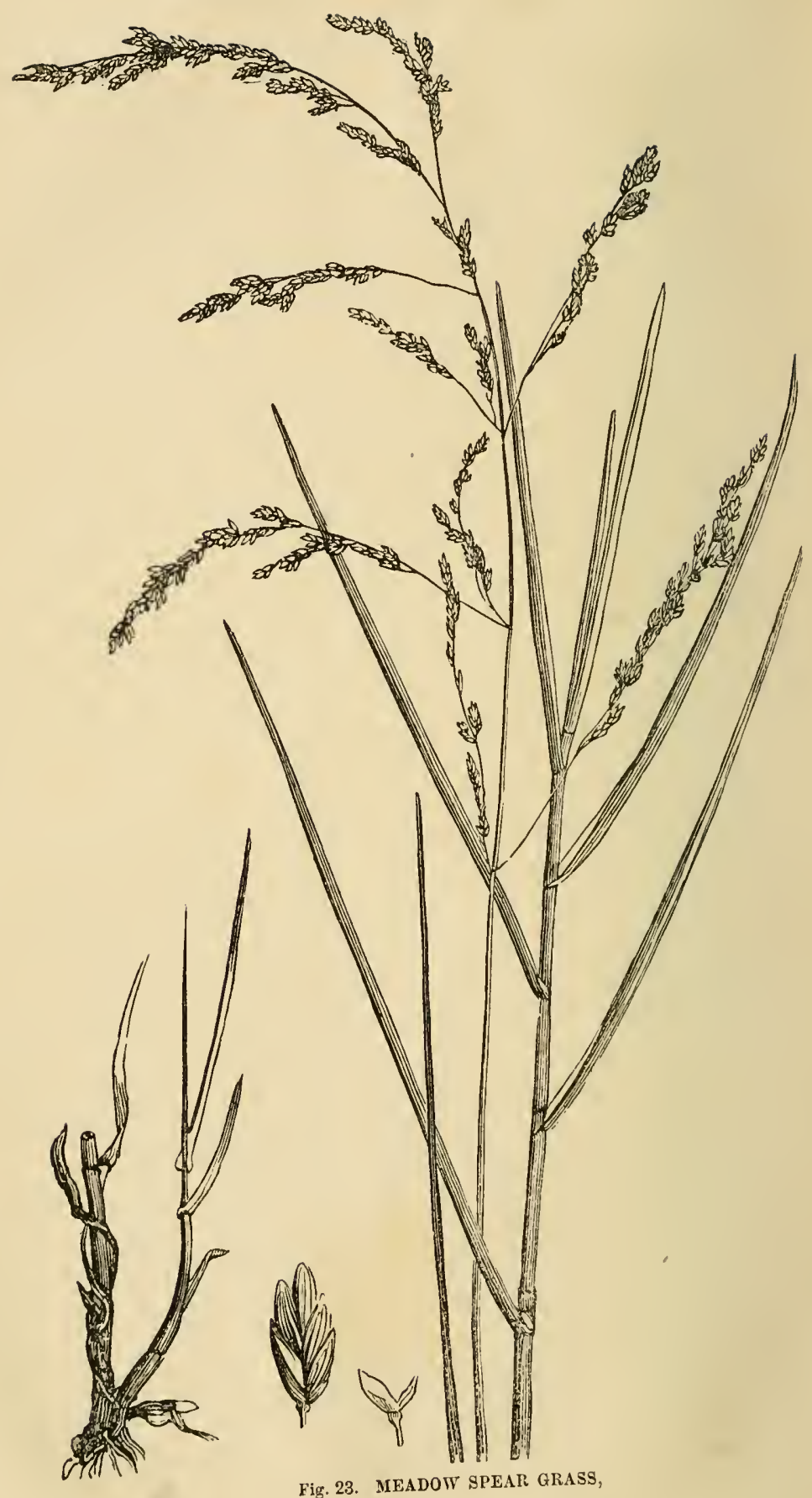


moist grounds, and is said also to sueceed on light upland soils. It is somewhat coarse, and not particularly relished by cattle, though readily eaten in winter. It would be a raluable ingredient in a mixture for moist pastures. It is not rery common. It is seen in Fig. 23, while in Fig. 23 (1) is seen a magnified spikelet, and the ealyx in (2.) Native of North America.

The Pale Manna (irass, (glyceria pallida,) grows mostly in shallow water, and is very common. Panicle erect with hairy branches, spreading, rough ; spikelets few, lincar, oblong, five to nine flowered; lower palea oblong, minutely five toothed; leares short, sharp pointed and pale green. Flowers in July. Culms one to three feet long, creeping at the base.

One or two other species are referred to this genus, glyceria, as the Reflexed Meadow Grass, (glyceria distans,) found in salt marshes, along the coast, and closely allied to the SEA Spear Grass, (poa marilima,) and the Acute Fescue Grass, (slyceria acutiflora, rarely found in low, wet places. Of no value in agriculture.

SPIKe Grass, (brizopyrum spicatum,) is a salt marsh grass, with culms or stems in tufts from creeping root-stalks, from ten to eighteen inches high. Flowers in August.

Green Meadow Grass, June Grass, Common Spear Grass, Kentucky Blue Grass, de., (poa pratensis.) The characteristics of the genus poa, are, orate spikelets, compressed, flowers two to ten in an open panicle, glumes shorter than the flowers, lower palea compressed, kecled, pointless, five nerved, stamens two or three, seed oblong, free, stems tufted, leares smooth, flat and soft.

Specific characters: Lower florets connected at the base by a web of long, silky filaments, holding the calyx; outer palea, five ribbed, marginal ribs hairy, upper sheath longer than its leaf; height from ten to fifteen inches, root perennial, creeping, stem erect, smooth and round, leares linear, flat, acute, roughish on the edges and inner surface; panicle diffuse, spreading, erect. The plant is of a light green color, the spikelets frequently variegated with brownish purple. Introduced. Flowers in June. Fig. 24 represents this grass, and Fig. 25, a flower magnified.

This is an early grass, very common on the soils of New England in pastures and fields, constituting a considerable por- 
tion of the turf. It varies very much in size and appearance according to the soil on which it grows. In Kentucky it is universally known as Blue grass, and elsewhere frequently called Kentucky blue grass, and still more frequently, June grass. It has been called by some, without much reason, the most raluable of all the grasses in our pastures. It comes into the soil in some parts of the country when left to itself, and grows luxuriantly on soils best suited to it, and is relished by all cattle. Its creeping root is said by some to imporerish the soil. Whererer it is intended for hay it is cut at the time of flowering, as if the seed is allowed to ripen, more than a fourth part of the crop is lost. In its earliness, it is equalled by some of the other grasses, and in its nutritive constituents by sereral. After being cut

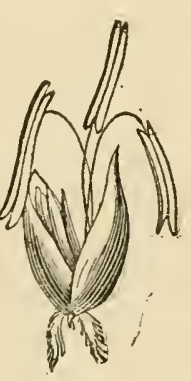

Fig. 25.

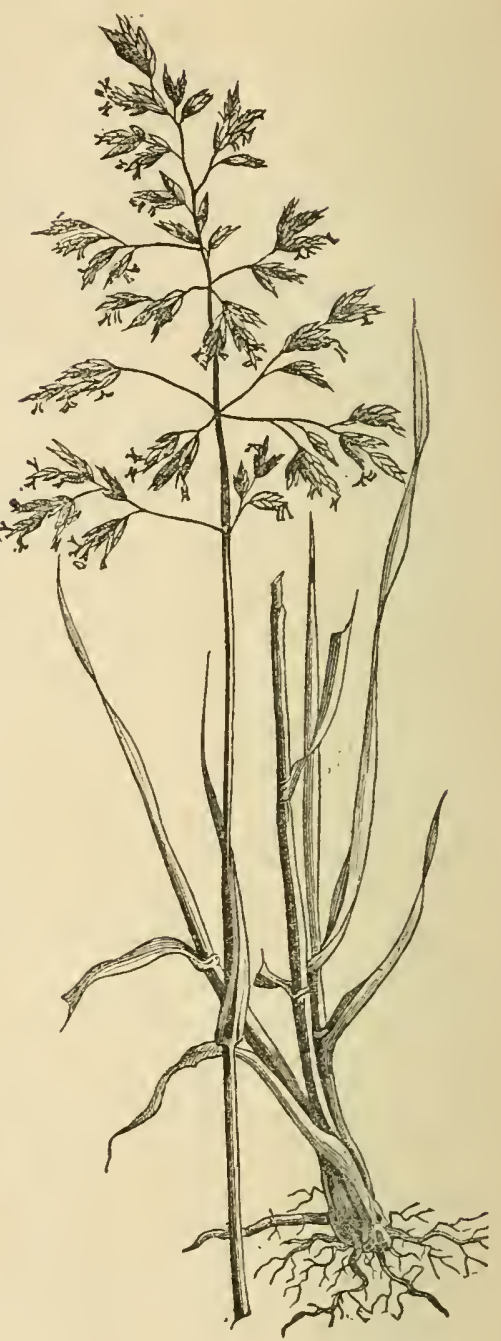

Fig. 24. June Grass.

in summer it starts up slowly. Low says: "It is inferior to the rough stalked meadow grass, and it may be questioned whether it deserves to be reckoned among the superior pasture grasses."

It produces but one flowering stem in a year, while many of the other grasses continue to shoot up flower stalks, and run to seed through the season. On this account it is recommended highly for lawns, where uniformity is desired. The produce ordinarily is small, compared with other grasses, but the herb- 
age is fine. It grows well in rather a dry soil, but will grow on a variety of soils, from the dryest knolls to a wet meadow. It does not withstand our serere droughts as well as some other grasses. Its reputation is far higher in this, than in its native country, where it is denied by most farmers eren a place among the grasses to be recommended for cultiration. It endures the frosts of winter better, perhaps, than most other grasses; and in Kentucky, where it attains the highest perfection as a pasture grass, it sometimes continues luxuriant through their mild winters. It requires at least two or three years to become well set, and it does not arrire at its perfection as a pasture grass till the sward is older than that, and hence it is not suited to alternate husbandry, or where the land is to remain in grass only two or three years and then be ploughed up. In Kentucky, the best blue grass is found in partially shaded pastures. A well known farmer of that State, in a communication to the Ohio Farmer, says: "In our climate, and soil, it is not only the most beautiful of grasses, but the most raluable of crops. It is the first deciduous plant which puts forth its leares here; ripens its seed ahout the tenth of June, and then remains green, if the summer is farorable in moisture, during the summer months, growing slowly till about the last of August, when it takes a second rigorous growth until the ground is frozen by winter's cold. If the summer is dry, it dries up utterly, and will burn if set on fire; but even then, if the spring growth has been left upon the ground, is very nutritious to all grazing stock, and especially to sheep and cattle, and all ruminating animals. When left to have all its fall growth, it makes fine winter pasture for all kinds of grazing animals. Cattle will not seek it through the snow, but sheep, mules and horses will paw off the snow and get plenty without any other food. When corered with snow, cattle require some other feeding; otherwise they do well all winter upon it.

"It makes also the best of hay. I hare used it for that for twenty years. It should be cut just as the seeds begin to ripen, well spread, and protected from the dew at night by windrowing or cocking; the second erening stacked, with salt, or sheltered, with salt also. When properly cured, stock seem greatly to prefer it to all other hay. I would not recommend it for meadow, especially, howerer, because the yield is liardly equal 
to Timothy and clover, and because it is more diffieult to eut and cure."

The same writer says: "Any time in the winter, when the snow is on the ground, sow broadeast from three to four quarts of clean seed to the acre. With the spring the seeds germinate and are very fine in the sprouts, and delicate. No stock should be allowed for the first year, nor until the grass seeds in June, for the first time in the second year. The best plan is to turn on your stock when the seed ripens in June. Graze off the grass, then allow the fall growth and graze all winter, taking eare never to feed the grass elosely at any time."

Another eminent cattle breeder speaking of this grass, says: "Perennial grasses are the true basis of agriculture, in the highest condition of that best employment for man. Grasses which are not perennial, are of immense value, especially as one of the shifts in the ordinary rotation of erops, suited to the agriculture of the great upper, or northerly portion of our continent, all of it above the cotton line. But it is the grasses which are perpetual, that I chicfly allude to, and among these, emphatically the blue grass, as it is called in the regions where it flourishes most. Whoever has limestone land, has blue grass; whocrer has blue grass, has the basis of all agricultural prosperity; and that man, if he have not the finest horses, cattle and sheep, has no one to blame but himself. Others, in other circumstances, may do well; he ean hardly avoid doing well, if he will try."

By reference to a table on a subsequent page, containing the results of the recent investigations of Prof. Way, the distinguished ehemist of the Royal Agrieultural Society of England, it will be seen how inferior this grass is when green, to Timothy, for instance, in all the nutritive, flesh-forming, and especially in the fat-forming principles which contribute so largely to the derelopment and support of the whole animal system. The reader is referred to that table, and to another following it, containing analyses of these plants when dried and freed from water, and to the explanatory remarks on the nutritive principles of plants, which precede those tables.

Blue Grass, or Wire Grass, (poa compressa.) Stems ascending, flattened, the uppermost joint near the middle, leaves short, bluish green, panicle dense and contracted, ex- 
panding more at flowering; short branches often in pairs, corered with four to nine flowered, flat spikelets; flowers rather obtuse, linear, hairy below on the keel ; ligule short and blunt; height about a foot. It is rery common on dry, sandy, thin soils and banks, so hardy as to grow on the thin, hard soils "covering the surface of rocks, along trodden walks, or" grarelly knolls. It shoots its leaves early, but the amount of its foliage is not large, otherwise it would be one of our most valuable grasses, since it possesses a large per cent. of nutritive matter. Flowers in July. Most grazing animals eat it greedily, and it is especially relished by sheep. Its bluish green stems retain their color after the seed is ripe. It shrinks less in drying than most other grasses, and consequently makes a hay very heary in proportion to its bulk. It is an exceedingly valuable pasture grass on dry, rocky knolls and should form a portion of a mixture for such soils. This should not be confounded with Kentucky blue grass alluded to above.

Axvel Spear Grass, (poa amuna, sec Fig. 1,) is, perhaps, the most common of all our grasses. Its stems are spreading, flattened, panicle often one sided, spikelets crowded, three to seren flowered, lower palea more or less hairy on the nerves below ; leares of a light green, sword-shaped, flat, often crumpled at the margins, as appears in Fig. 1, smooth on both surfaces, rough at the edges. Florels not webbed, and this distinguishes it from the June grass, (poc pratensis,) and its varicties. The onter or lower palea of this grass has no hairs on the lateral ribs as the poa pratensis has. This modest and beautiful grass flowers throughout the whole summer and forms a very large part of the sward of New England pastures, producing an carly and sweet feed, exceedingly relished by cattle. It does not resist the drought rery well, but becomes parehed up in our pastures.

The Rough Stalked Meadow Grass, (poa trivialis,) though not so common as the June grass, (poa pralensis,) is still often met with, and is found to have webbed florets; outer palea five ribbed, marginal ribs not hairy, ligule long and pointed, stems two to three feet high. Distinguished from Jume grass by having rough sheaths, while in the latter the sheaths are smooth, the ligule obtuse and the marginal ribs of onter palea furnished with hairs. The rough stalked meadow' grass has a fibrous 
root, that of the June grass is creeping. It flourishes in moist meadows where it flowers in July. Introduced. This grass is seen in Fig. 26, while Fig. 27 represents a flower somewhat magnified.

This is a valuable grass to cultivate in moist, sheltered soils, possessing rery considerable nutritive qualities, coming to perfection at a desirable time, and being exeeedingly relished by cattle, loorses and sheep. For such soils it should form a portion of a mixture of seeds, producing, in mixture with other grasses which serve to shelter it, a large yield of hay, far above the average of grass usually grown on a similar soil. It shonld be eut when in seed and not in the flower. Seven pounds of seed to the acre will produce a good sward. The grass loses about serenty per cent. of its weight in drying. Its hay contains about one and sixty hundredths per cent. of azote, and the nutritive qualities of the lattermath exceed very considerably those of the erop cut in the flower or in the seed.

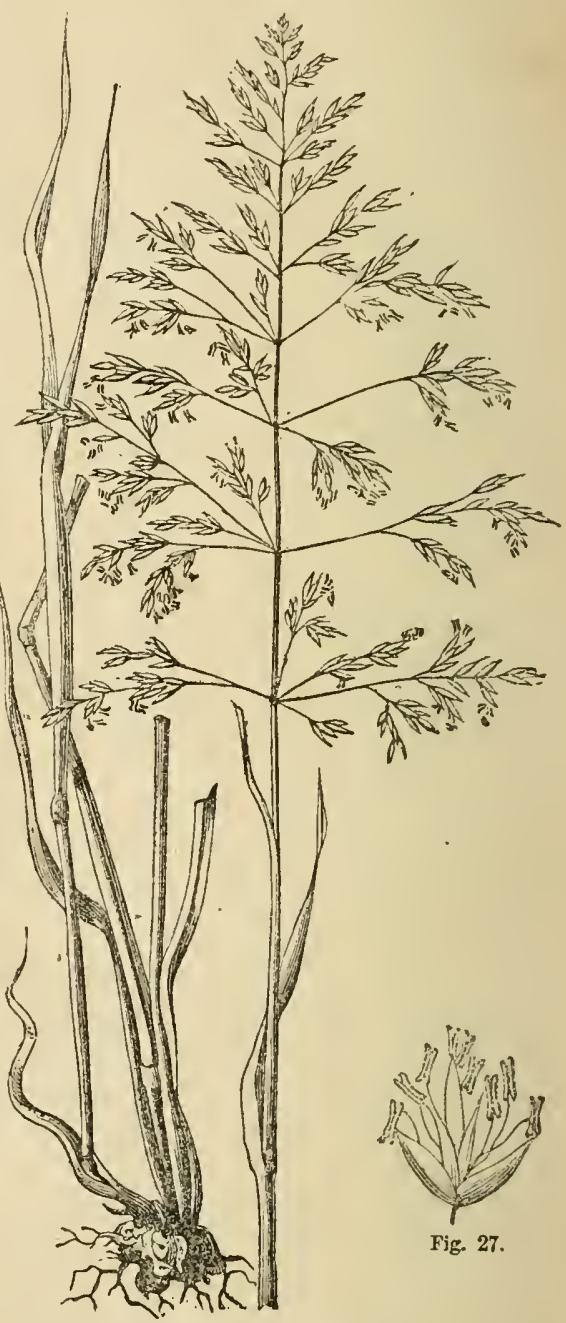

Fig. 26. Rough Stalk lieadow Grass.

Wood Meadow Grass, (poa nemoralis,) is metwith in Hampshire and Berkshire counties. It grows from eighteen inches to two feet high, has a perennial, creeping root, an erect stem, 
slender, smooth, the upper sheath no longer than its leaf, with a very short ligule, the base of the floret having a silky web suspending the calyx, leaves, light green. It is common in moist, shady places, and appears as a tall, rank grass, with a long, fincly arched panicle. It flowers in June and ripens its seed in July.

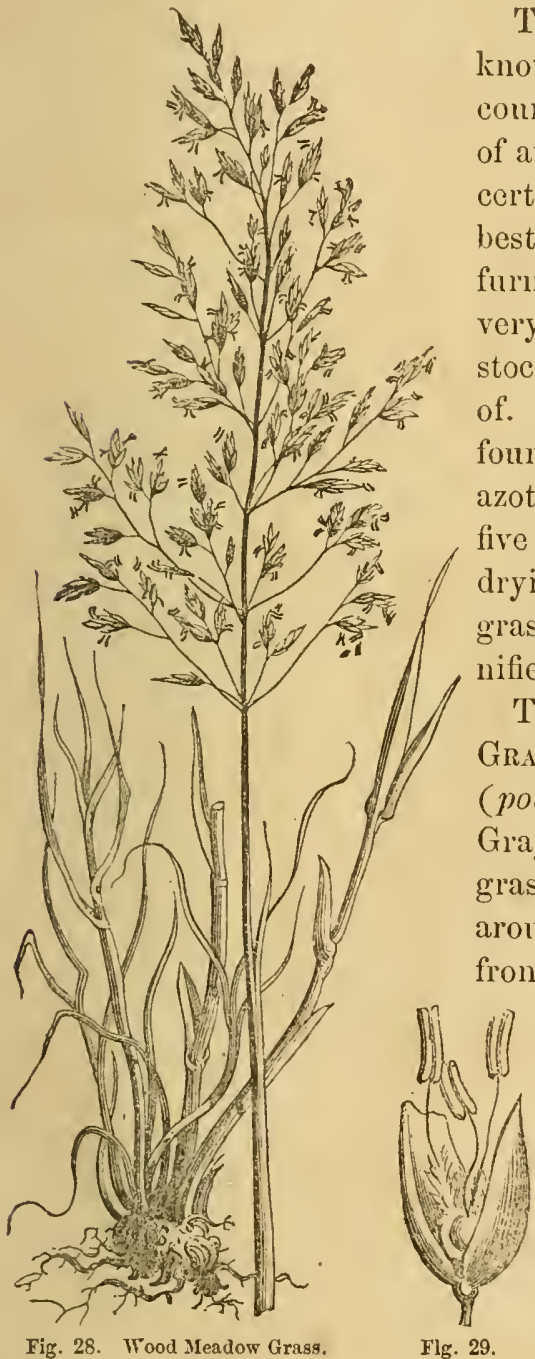

Fig. 28. Wood Meadow Grass.

Though it has never to my knowledge been cultivated in this country, it appears to me worthy of attention for moist soils. It is certainly to be classed among the best of shaded pasture grasses, furnishing a fine, suceulent and very mutritive herbage, which stock of all kinds are very fond of. Hay contains one and sixtyfour one-humclredths per cent. of azote. The grass loses about fiftyfive per cent. of its weight in drying. Fig. 28 represents this grass in blossom ; Fig. 29 a magnified flower.

The Creeping Sea Meadow Grass, or Sea Spear Grass, (poa maritima,) referred by Gray to glyceria, is a beantiful grass which appears in and around salt marshes, growing from six to twelve inches high, and laving a perennial, creeping root. Stem erect, round, smooth, leaves mostly folded and compressed, roughisl on the inner surface, spikelets linear, with from six to ten florets not webbed, the outer palea of lower floret terminating in an acute point. Flowers in July. Grows naturally near the sea. It is seen in Fig. 30, and its flower magnified, in Fig 31. 


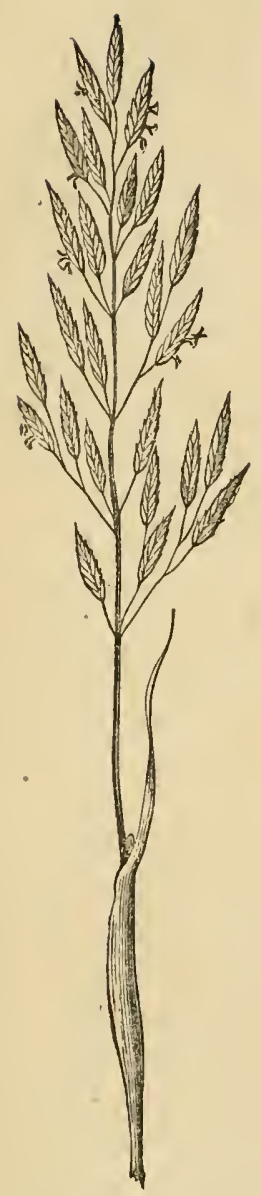

Fig. 30. Sea Spear Grass.

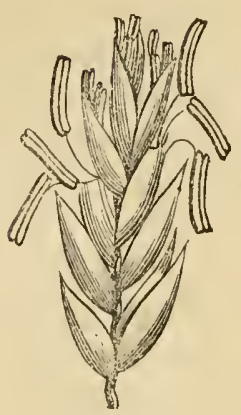

Fig. 31 .

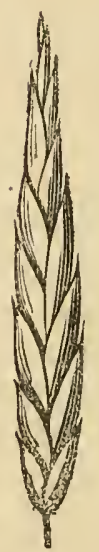

Fig. 33 .

The Floating Meadow Grass, or Common Manna Grass, (poa fluitans,) referred by Gray to glyceria, differs from the other species of the poa genus in the general appearance of its slender panicle and long, linear spikelets. It grows from fifteen inches to two feet high, with a perennial, creeping root, ereet, round, smooth stem, leaves large, rather long, roughish on both sides, lower ones flat, upper ones generally folded; spikelets few, long and linear, as shown in Fig. 32, which represents the 
plant near the time of flowering. Fig. 33 shows a magnified spikelet of this grass, florets not webbed. Flowers late in June.

This grass grows naturally in rery moist and muddy places, in ditches, on the margins of ponds and streams, and is very common. It is capable of cultivation as a permanent pasture grass, and its yield compares well with many of the other grasses. Its seeds are greedily sought by birds, and in some parts of Germany are said to be used as a delicaey in soups and gruels.

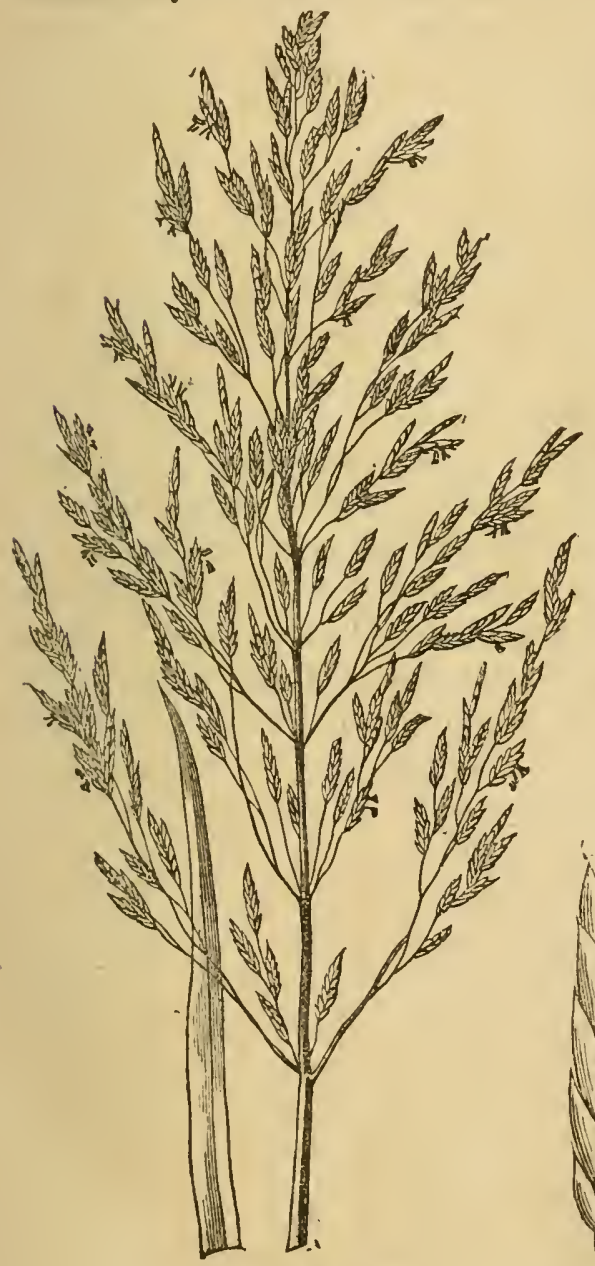

The WayY Meadow Grass, (poa laxa,) occurs rarely on high and rocky hills, but is not sufficiently common or raluable to need description.

The WATER SPEAR Grass, or Reed Meadow Grass, (poa aquatica,) grows in wet soils, in Hampshire County; is a tall, reedy grass, four or five feet ligh with a panicle nearly a foot long, diffuse, with smooth, flexuous branches. From its large size and broad leaves it can hardly be mistaken for any of the i) other species of poa. Its root is perennial, creeping, stem ereet, stout, smootl, joints sereil, smooth, spikelets numerous, florets not webbed. Flower's in August. Seen in Fig. 34, and its spikelet in Fig. 35: Fig. 34. Water Spear Grass. Fig. 35. This grass is referred 
by Gray and others, to glyceria. It is very common in wet meadows and will be easily recognized. More nutritive when in flower than when the seed is ripe. It contains a comparatively large per cent. of sugar. Makes a valuable fodder and cattle are very fond of it.

Several other species belonging to this genus, are frequently met with, as the Branching Spear Grass, on dry sandy soils, a very elegant species, with a large panicle of sea-green spikelets; the Hair Spear Grass, also an elegant grass growing on similar soils, with a hairy branching panicle over a foot long, leares linear, nerved. But perhaps the most important of all is the Fowl Meadow, or False Redtop, (poa serotina.) [See Frontispiece.]

The specific characteristics of this species are two to four, sometimes fire, flowered spikelets, oral, spear shaped, ligules elongated, flowers acutish, green, often tinged with purple, roots slightly ereeping; wet meadows and banks of streams, very common. Flowers in 'July and August. In long continned moist weather the lower joints send up flowering stems. The panicle is erect and spreading when in flower, but more contracted and drooping when ripe. It is peremnial. Native of Germany.

It early commended itself to the attention of farmers, for Jared Eliot, writing in 1749, says of it: "There are two sorts of grass which are natives of the country, which I would recommend,--these are Herds-grass, (known in Pennsylvania by the name of Timothy-grass,) the other is Fowl Headow, sometimes called Duck-grass, and sometimes Swanp-ucire Grass. It is said that IIerds-grass was first found in a swamp in Piscataqua, by one Herd, who propagated the same; that Fowl Meadowgrass was brought into a poor piece of meadow in Dedluam, by ducks and other wild water-fowl, and therefore called by such an odd name. It is supposed to be brought into the meadows at Ifartford by the anmul floods, and called there Swamp-wire grass. Of these two sorts of natural grass, the fowl-grass is mich the best; it grows tall and thick, makes a more soft and pliable hay than IIerds-grass, and consequently will be more fit for pressing, in order to ship off with our horses; besides it is a good grass, not in abundance inferior to English grass. It yields a good burden, three loads to the acre. It must bo sowed in low, moist land. This grass has another good quality, which 
renders it very valuable in a country where help is so much wanting; it will not spoil or suffer, although it stand beyond the common times for mowing. Clover will be lost, in a great measure, if it be not cut in the proper season. Spear-grass, commonly ealled Engish grass, if it stands too long, will be little better than rye straw ; if this outstand the time, it is best to let it stand till there comes up a second growth, and then it will do tolerably well; but this fowl-grass may be mowed any time from July to Oetober. * * * This I wondered at, but viewing some of it attentively, I think I have found the reason of it. When it is grown about three foot ligh it then falls down, but doth not rot like other grass when lodged; in a little time after it is thus fallen down, at erery joint it puts forth a new branch ; now to maintain this young brood of suckers there must be a plentiful course of say conveyed up through the main stem or straw; by this means the grass is kept green and fit for mowing all this long period."

This grass grows abundantly in almost every part of New England, especially where it has been introdueed and enltivated in suitable ground, such as the borders of rivers and intervals occasionally overflowed. It will not endure to be long covered with water, especially in warm weather. It is well to let a piece go to seed, sare the seed and seatter it over low lands. It makes an execllent grass for oxen, cows and sheep, but is thought to be rather fine for horses. It never grows so coarse or hard but that the stalk is swect and tender and eaten without waste. It is rery easily made into hay, and is more nutritive, according to Sinclair, than either foxtail, orebard grass, or tall meadow oat grass. Owing to its constantly sending forth flowering stems, the grass of the lattermath contains more nutritive matter than the first crop at the time of flowering, hence the names fertilis and serotina, fertile and late flowering meadow grass. It thrives best when mixed with other grasses, and deserves a place in all mixtures for rich moist pastures.

The Creeping Meadow Grass, (eragrostis reptans,) is frequently found on the sandy banks of rivers, and is a beautiful and delicate grass. Flowering in July and dugust. Its leares are short, nearly awl-shaped, spikelets smooth, long and lance shaped, flowers aente, sheaths loose, striate and a little hairy on 
the margin, panicles from one to two inches long. Not a cultivated grass.

The Strong-Scented Meadow Grass, (eragrostis pocooides,) is sometimes found in sandy fields, roadsides, cultivated grounds and waste places. Its lẹares are flat and smooth, lower sheaths hairy, spikelets containing from ten to twenty florets of a lead color. It flowers in August and September. Of no importance in agriculture.

A variety of this grass (the megastachya) is found more frequently on similar situations; flowering about the same time; emitting, when fresh, a sharp and disagreeable odor, by. which it may be known.

The Slender Meadow Grass, (eragrostis pilosia,) the Hatrpanicled Meadow Grass, (eragrostis capillaris,) the Hairy Meadow Grass, (eragrostis pectinacea,) are found in this State, but they are of no special importance for cultivation. They all occur on sandy, dry, waste places, the last only near the coast, and all flower in August and September.

Quaking Grass, (briza media,) is sometimes met with in the eastern part of the State, as in the pastures of Dorehester. Panicle erect, with very slender spreading branches, and large, purplish, tremulous spikelets from five to nine flowered, inner glume fincly fringed, entire at the end. (Fig. 36.) In Fig. 37 is shown a magnified spikelet. It is a very beautiful, light, slender grass, about a foot high, perennial. Flowering in June and July. There is an anmual, the Large Quaking Grass, (briza maxima,) with large many-flowered spikes, cultivated in gardens for ornament.

Sirall Fescue Grass, (festuca tenella.) The generic characters of this geuus are oblong spikelets, somewhat compressed, from three to many flowered, two very unequal glumes, pointed, palex roundish on the back, from three to five nerved, awn pointed or bristle shaped, stamens three, flowers harsh, often purplish, panicle nearly erect, leares narrow, rigid, of a grayish green.

The small fescue has a spike-like panicle, somewhat one-sided, from seven to nine flowered, awn of the awl-shaped palea, slender, leaves bristle-formed, stem slender, six to twelve inches high. It flourishes on dry and sterile soils, and is common. Flowers in July. 


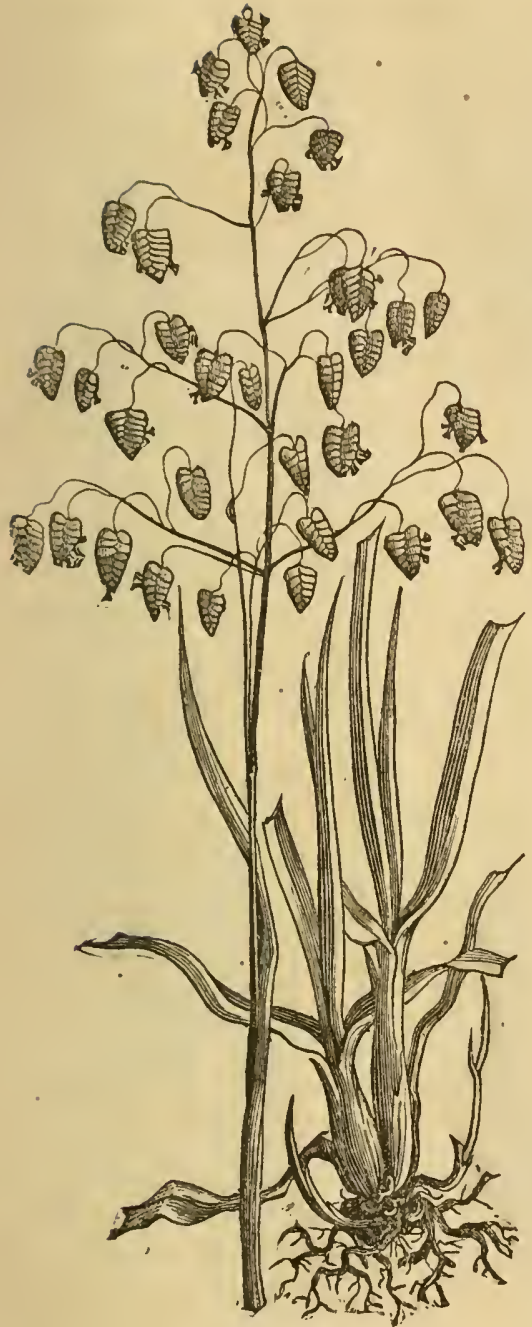

Fig. 36. Quaking Grass.

Sheep's Fescue, (festuca ovina, is known by its narrow panicle, short, tufted, bristle-shaped leaves, of a grayish color, somewhat tinged with red, its two to six flowered spikelets, awn, often nearly wanting. It grows from six to ten inches high in dense perennial rooted tufts. It forms an excellent pasturage for sheep. It flowersin June and July, in dry pastures. In Fig. 38 is seen the form of this grass, and in Fig. 39 is shown a magnified spikelet of it.

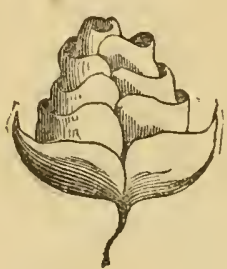

Fig. 37

Meadow Fescue, (festuca pratensis, ) is one of the most common of the fescue grasses. It is said to be the Randall grass of Virginia. Its panicle is nearly erect, branclied, close, somewhat inclined to one side; spikelets linear, with from five to ten eylindrical flowers; leares linear, of a glossy green, pointed, striated, rough an the edges; stems round, smooth, from two to three feet high, roots, creeping, perennial. Its radical or root leaves are broader than those of the stem, while in most other species of fescue the radical leaf is generally narrower than those of the stem. Flowers in June and July, in moist pastures and near farm houses. 


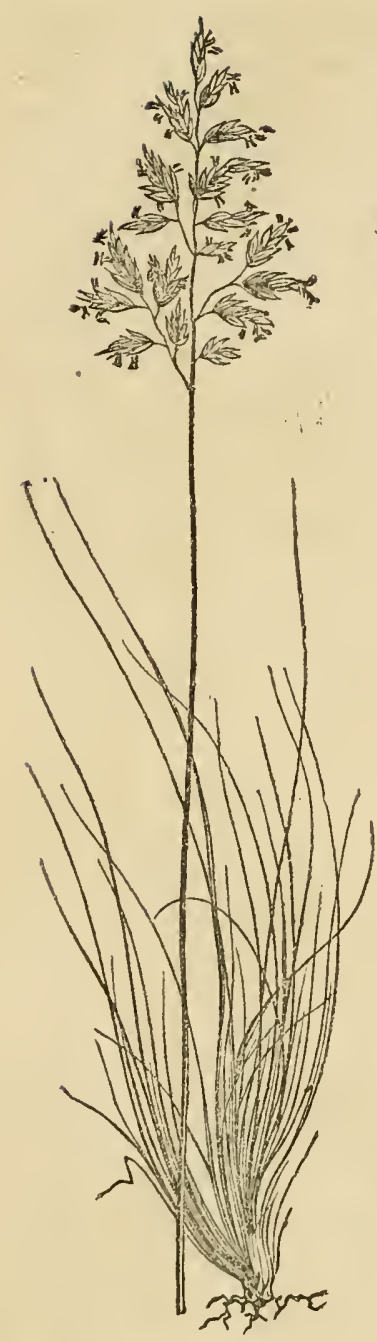

Fig. 39. Sheep's Fescue.

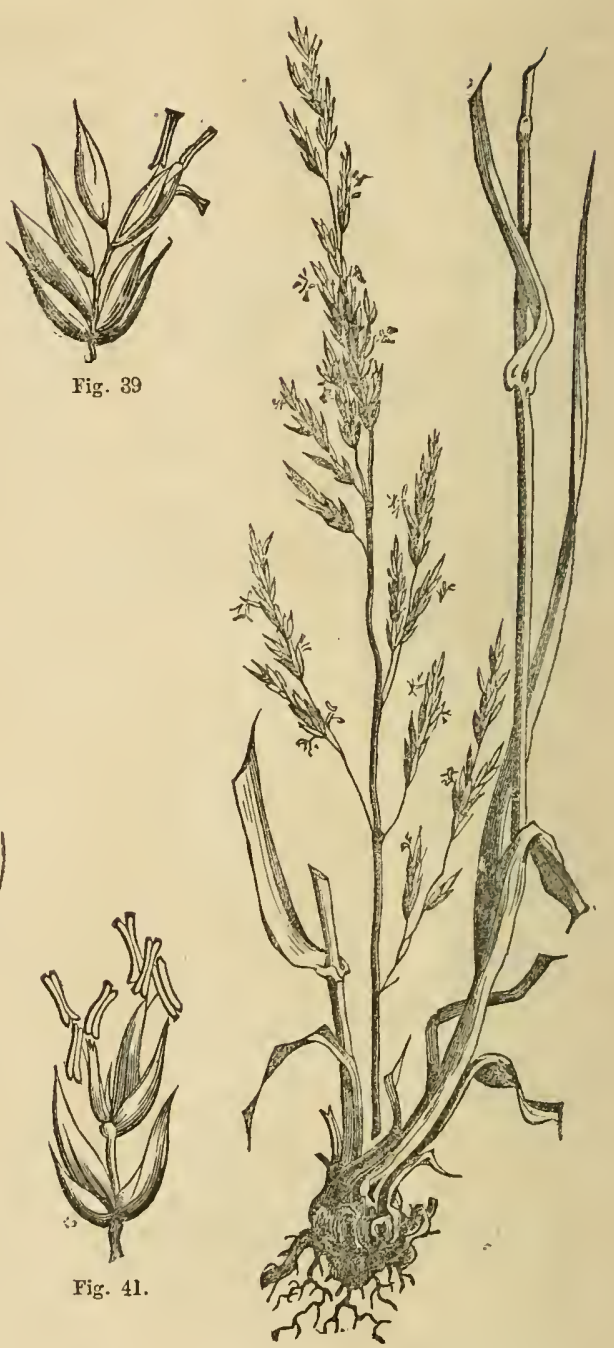

Fig. 40. Meadow Feseue.

This is an excellent pasture grass, forming a very considerable portion of the turf of old pastures and fields, and is more extensirely propagated and diffused by the fact that it ripens its seed before most other grasses are cut, and sheds them to spring up and cover the ground. Its long and tender leares are much relished by eattle. It is never or rarely sown in this country, notwithstanding its great and acknowledged value as a 
pasture grass. If sown at all, it should be in mixture with other grasses, as orehard grass, rye grass, or common spear grass. It is of much greater value at the time of flowering than when

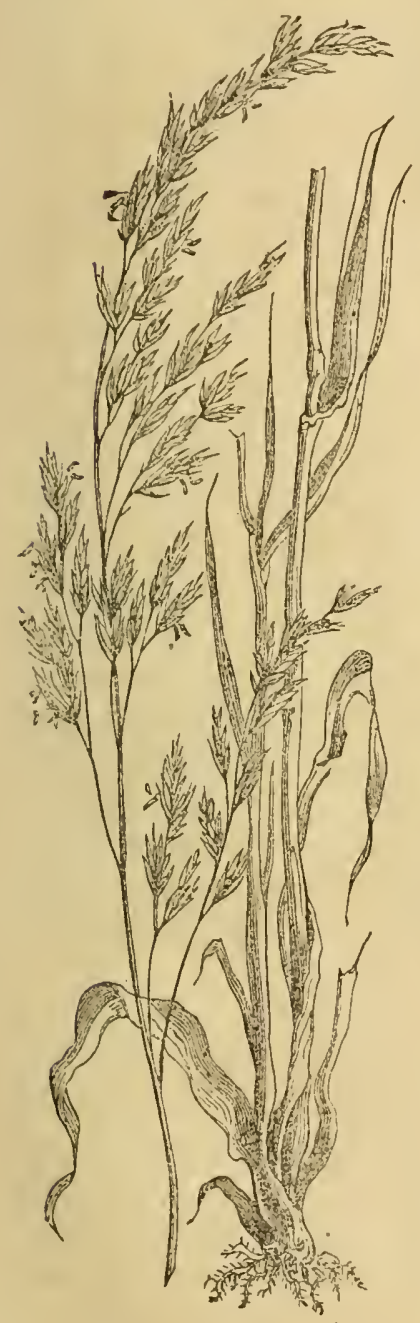

Fig. 42. Tall Fescue Grass.

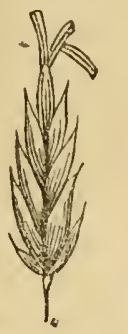

Fig. 43 .

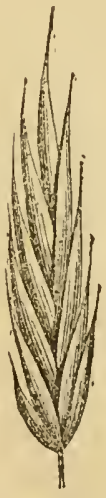

Fig. 45.

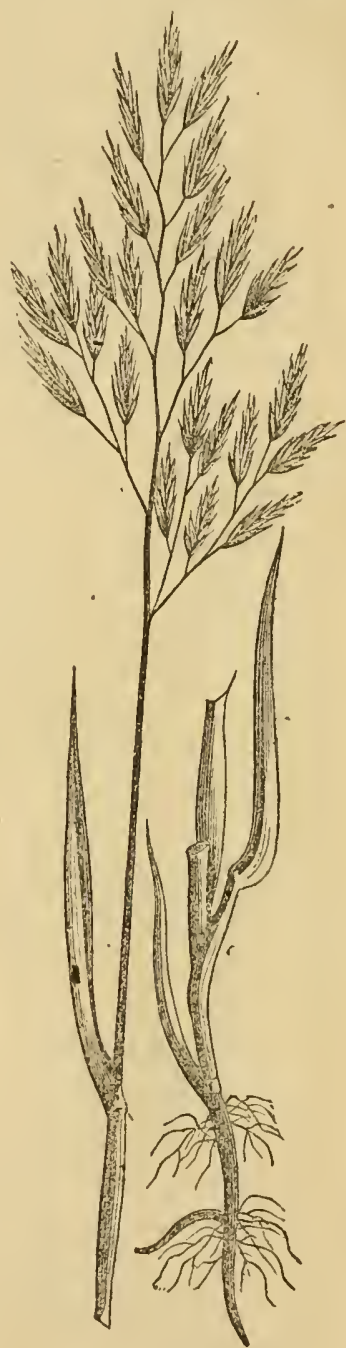

Fir. 14. Red Fescue.

the seed is ripe. It is said to lose a little over fifty per cent. of its weight in drying for hay. It is shown in Fig. 40, and its magnified spikelet in Fig. 41.

The Talu Fescue Grass, (festuca elalior,) is also found pretty 
commonly in moist meadows and around far'm liouses. Its panicle is contracted, erect, or somewhat drooping, with short branches, spreading in all directions; spikelets crowded, with fire to ten flowers, rather remote, oblong, lanceolate; leares flatish, linear, acute; stems two to four feet high, root peremial, fibrous, somewhat ereeping and forming large tufts. Fig. 42 shows this plant at the time of flowering, and Fig. 43 a magnified spikelet of the same. Flowers in June and July.

It is a nutritive and productive grass, growing naturally in shady woods and moist, stiff soils. Cattle are very fond of it. Said by some to be identical with the meadow fescue.

The Hard Fescue Griss, (festuca duriuscula, is also found to some extent, though not so commonly as the meadow fescue. It is by some regarded as a rariety of the sheep's fescue, taller and with a panicle more open, leares flat, and spikelets four to eight flowered. It grows from one to two feet high. Flowers in June, in pastures and waste grounds.

The Red Fescue, (festuca mbra,) by some regarded as only a variety of the preceding, is one of the largest of the varieties of fescue. Its leaves are broadish, flat, root extensirely creeping, and throwing out lateral shoots. Found in dry pastures near the sea shore, in sandy soils. It is a grass of better quality than some of the other rarieties, but never cultivated here as an agrieultural product. The color of its leares is somewhat more grayish than the preceding and often tinged with red. It is shown in Fig. 14 , while its spikelet is seen magnified in Fig. 45.

The Slender Spiked Fescur, (fesluca loliacea, is a species nearly allied to the tall fescue and possesses much the same qualities. It grows naturally in moist, rich meadows, forming a good permanent pasture grass, but as it is met with only rery rarely, if erer, among American grasses, and is of no value for cultivation, it scarcely deserres a more extended notice. Fig. 46 , a specimen of this plant in blossom. Fig. 47, a magnified flower of it.

The Nomngr Fescur, (fesiuca nutans,) is also rarely met with in rocky woods, and needs only to be mentioned.

Crested Dog's 'Thih, (cynosurus cristalus.) (Fig. 48.) This grass is rarely found here, and scarcely needs description. Its spikes are simple, linear, spikelets awnless, stems one foot 


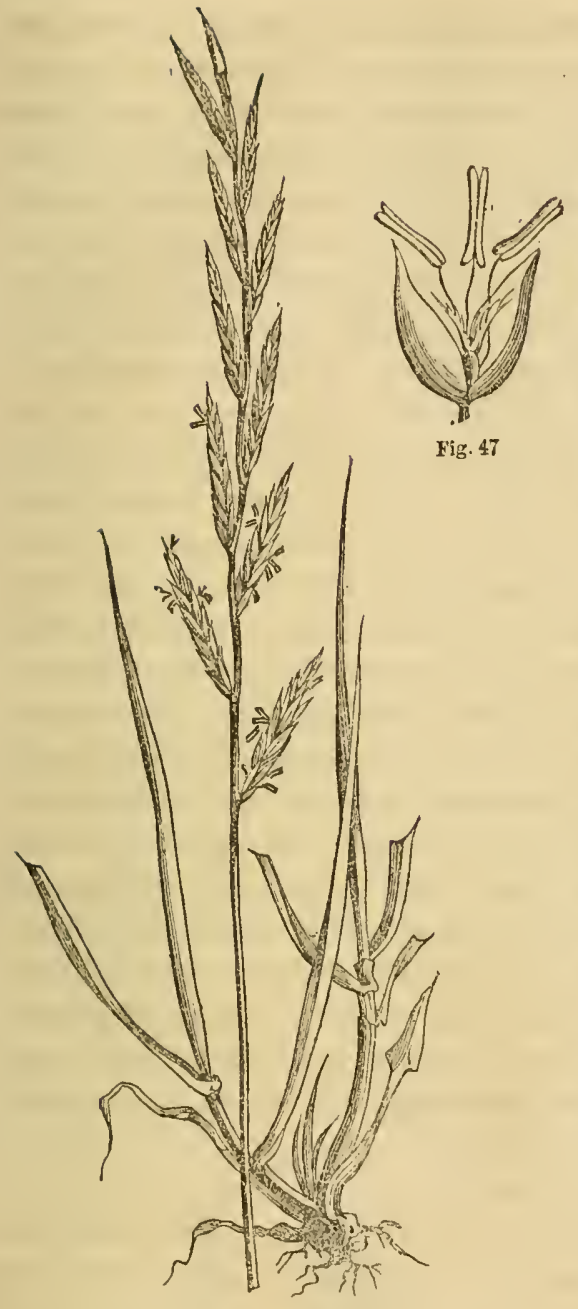

Fig. 46. Slender Fescue.

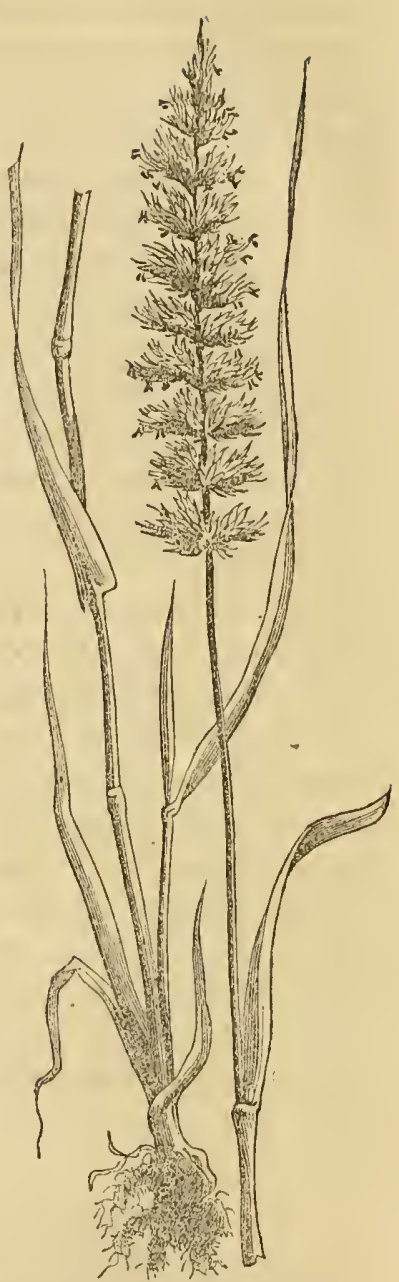

Fig. 48. Crested Dog's Tail.

high, stiff, smooth, root peremial, fibrous and tufted. Flowers in July. It is said by some to be a valuable agrieultural grass, but cattle seldom eat it, on account of its wiry stems; but on dry, hard soils and hills pastured with sheep, it is of value as a liardy, permanent grass. It is used in the manufacture of straw plait. Fig. 49 represents a magnified spikelet of the crested dog's tail.

Willard's Bronus, Chess, Cheat, (bromus secalinus.) The 
characteristics of this genus (bromus) are, spikelets from five to many flowered, panicled, glumes not quite equal, shorter than the flowers, mostly keeled,--the lower, one to five, the upper, three to nine nerved,-palex herbaceous, lower one convex on the back, or compressed, kecled, five to nine nerred, awned or bristle pointed from below the tip, upper palea at length adhering to the groove of the oblong grain, fringed on the keel, stamens three, styles attached below the apex of the ovary. The grasses of this genus are coarse, with large spikelets, somewhat drooping generally when ripe.

The specific eharacteristics are, a spreading panicle slightly drooping, spikelets orate, smooth, of a yellowish green tinge, showing the rachis when in seed, and lolding from six to ten rather distinct flowers. In the spikelet exhibited in the cut, (Fig. 50 ,) seven can be distinçtly counted, the eighth or ninth imperfectly developed can often be found; stems erect, smooth, round, from two to three feet high, bearing four or fire leaves with striated sheaths; the upper sheath crowned with an obtuse, ragged ligule, the lower sheaths soft and hairy, the hairs pointing downwards; joints five, slightly hairy, leaves flat, soft, linear, more downy on the upper than on the under side, points and margin rough to the touch. Summit of the large ghume midway between its base and the summit of the second floret, a constant mark of distinction from bromus racemosus and bromus mollis. (Fig. 50,) (b.) Fig. 51 shows the form of the spikelet a few days before coming to maturity. Flowers in June and July. It has no relation to Italian rye grass.

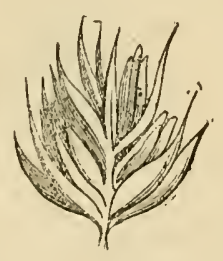

Fig. 49.

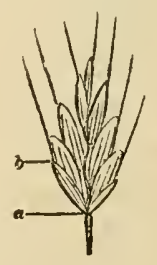

Fig. 50.

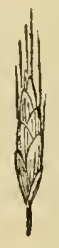

Fig. 61.

Distinguished from bromus arvensis in the spikelets having fewer florets, and the outer palea being rounded at tho summit.

Nothing more clearly illustrates the want of accurate knowledge of subjects intimately comnected with agriculture, and immediately affecting the farmers' interests, than the history of 
the introduction and propagation of this worthless pest to our grain ficlds. It has been lieralded in the papers, in connection with the names of distinguished friends of agriculture, with the earnest hope that it might receive extended trials. Monstrous prices have been charged and paid by the unsuspecting farmer for its seed, in many cases four and fire dollars a bushel, a pledge being exacted that it should not be allowed to go to seed, for a reason, probably, which will shortly appear. Committees of agricultural soeieties have been invited to examine and report upois it; and in a letter now lying before me, the disinterested propagator very kindly offers to put up ten barrels of bromus seed for $\$ 100$, saying, that " of course the earliest applicants will be sure of obtaining till all is gone, which would searcely give a barrel to a State. ** Years must elapse before the country can be supplied as it now is with Herds-grass and elorer seed. My offer invites eo-operation and participation in the profits and pleasures now arailable"-for taking adrantage of the lionest eredulity of the public?

A quantity of bromus seed was sent to the State Farm for the purpose of experiment, with a letter with directions to sow with clover in the spring of 1855 . The crop was eut while yet green, and before the grass had dereloped sufficiently to distinguish it with eertainty. 'This present year (1856) directions were given to let it stand later in the season. While engaged in the collection and study of specimens in the course of the summer, I gathered samples of this grass when it was still immature, the spikelets having very much the appearance indicated in Fig. 51. Without giving it a rery close examination at the time, I pronounced it the bromus arrensis, which at that stage of its growth it rery much resembles. A few days after, I was astonished to see it derelop into Chess (bromus sccalinus.) This was the first ripe specimen of Willard's bromus I had seen. I examined it with eare with a strong magnifying glass, and to aroid the possibility of mistake, I submitted specimens of it to Prof. Gray, of Cambridge, and to Prof. Dewey, of Rochester, New York, both of whom, after cxamination, pronounced it genuine chess.

But Mr. Willard having quoted from the report of a committee of an agricultural society in which it was said that if a "jury of eows should confirm the opinion of Mr. Willard as to the 
superiority of the grass, then will the agricultural community owe him a debt of gratitude for having introduced to notice here a species of grass which is highly beneficial on light sandy soils, much superior to any other species, and producing most abumdantly on land of better quality," I very recently directed this grass to be submitted to such a jury, cmpanelled and kept under the charge of Mr. L. P. Chamberlain at the State Farm, which unhesitatingly pronounced a verdict in accordance with the facts, which were as follows:-

The grass which was first submitted for comparison with the bromus was the Reed Canary grass, (phalaris arundinacea,) a grass of very slight nutritive and palatable qualities, as will appear by reference on a subsequent page to the careful analysis made of it at my request by Prof. E. N. Horsford, of the Lawrence Scientific School, Cambridge. The English hay used was such as commonly goes by that name among farmers, made up of Timothy and Redtop mainly, of fair quality. The meadow or swale hay was taken from a wet meadow, made up of coarse swale grasses, such as are common in eastern Massachusetts, and pass under the term of "meadow hay." 'The bromus was carefully picked out from all other grasses. The two kinds given in cach trial were put into the same crib, but separated by a partition.

First trial-Bromus and reed canary grass. There was no ehoice. Both were eaten alike till they wore gone.

Second-Bromus and English hay; preferred English hay.

Third-Bromus and swale hay;

Fourth-Bromus and oat straw;

Fifth_Cannry grass and English hay; " English hay.

Sixth-Canary grass and swale; " " swale at once.

Serenth-Canary grass and oat straw ; " " oat straw.

Eightl_-Canary grass and cormstalks; " cornstallss.

Ninth-Bromus and cormstalks. Ate nearly alike of each till both were gone.

Tenth-Bromus and millet. Chose the millet and did not touch the bromus.

This is a true transeript of the verdict of that intelligent jury, and it is precisely what I should have anticipated from what I knew of the grasses. The trial by jury should be final.

It is unnecessary to say that "Cheat" is a troublesome weed 
to the farmer, especially when it appears in his grain fields. It is an early grass, but the quantity of herbage, and especially its quality, make it unfit for cultivation. Indeed, the only species of any value, or at all fit for cultivation, belonging to this large genus of grasses, is the bromus arvensis, and even that has been discarded from modern agriculture.

I have been thus minute in speaking of this grass, because I have felt it my duty to disabuse the minds of farmers with regard to it, a duty in which I hare recently, and since the above was written, been anticipated by my friend, Sanford Howard, Esq., anthor of a raluable paper on the Grasses, in the Transactions of the New York State Agricultural Society, for 1855.

I have but little acquaintance with, and no prejudice against, Mr. Willard, but regret exceedingly that he or any one else should make a mistake so serious to the community, and take so much pains to propagate "cheat." Fortunately the plant is amnual. The fact of its liaring been eut before it was ripe, in 1855, accounts for its growing on the same piece in 1856.

Sirooth Brome Grass, or Upright Chess, (bromus racemosus,) has a panicle erect, simple, rather narrow, contracted when in fruit. Flowers closer than in the preceding, lower palea exceeding the upper, bearing an awn of its own length. Stem erect, round, more slender than in chess, sheaths slightly hairy. In other respects it is very much like Willard's bromus, but may always be distinguished from it as well as from bromus arvensis, in the summit of the large glume being half-way between its base and the summit of the third floret, on the same side; whereas in Willard's bromus the summit of the large glume is half-way between its base and summit of the second floret. This character is constant, and offers the surest mark of distinction. It is common in grain fields. Flowers in June. It is worthless for cultivation.

Soft Chess, or Soft Brome Grass, (bromus mollis,) is sometimes found. I procured beautiful specimens of it at Nantucket, where it was growing in the turf with other grasses on a sandy soil near the shore. Its panicle is erect, closely contracted in fruit, spikelets conical, orate, stems erect, more or less hairy, with the hairs pointing downwards from twelve to eighteen inches high, joints four or five, slightly hairy, leares flat, striated, hairy on both sides, rough at the edges and points; sum- 
mit of the large glume midway between its base and the apex of the third floret, by whieh it is always distinguished from Willard's bromus. Flowers in June. Birds are fond of the seed, which are large and ripen early. Of no value for cultivation.

The Wild Chess, (bromus kalmii,) is another species, found often in dry, open wood-lands. It las a small, simple panicle, with the spikelets drooping on hairy peduncles, seven to twelve flowered and silky; awn only one-third the length of the lanceshaped flower, stem slender, eighteen inches to thrce feet high, leaves and sheaths hairy. Flowers in June and July. Of no value for eultivation.

Fringed Brome Grass, (bromus ciliatus,) is often found in woods and on rocky hills and river banks. It has a compound panicle, very loose, nodding, spikelets seven to twelve flowered, flowers tipped with an awn half to three-fourths their length, stem three to four feet high, with large leaves. Flowers in July and August. Of no value for cultivation.

The Meadow Brome Grass, (bromus pratensis,) is a perennial weed in the corn fields of England, and is only recommended in any part of Europe for dry, arid soils, where nothing better will grow. Fig. 52 represents this grass, and Fig. 53 a magnified spikelet.

Not one of the brome grasses is worthy of a moment's attention as a cultivated agricultural grass, and the cleaner the farmer keeps his fields of them the better.

The Connon Reed Grass, (phragmiles communis,) is a very tall, broad-leaved grass, with the flower in a large terminal panicle. It looks at a little distance very much like broomcorn; stem five to twelve feet high. It grows on the borders of ponds and swamps. It is said to be the largest grass in the United States. It ocenrs in several localities in Franklin County, and it is not uncommon in the eastern part of the State. Flowers in September.

Perennial Rye Grass, common Darnel, (lolium perenne.) Generie eharacters-spikelets many flowered, solitary on each joint of the continmous rachis, plaeed edgewise. Specific eharacters-stem oreet, smooth, fifteen inches to two feet high, root peremnial, fibrous, joints four or five, smooth, often purplish, learcs dark green, lanceolate, acute, flat, smooth on the outer surface 


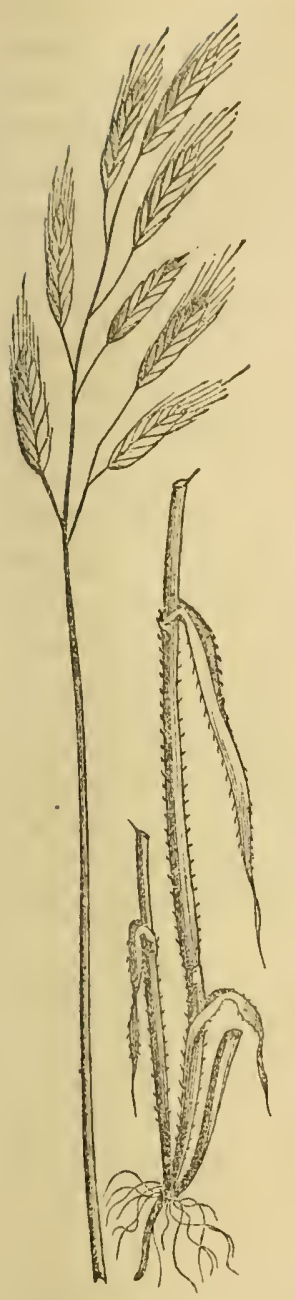

Fig. 52. Meadow Lrowe Grass.

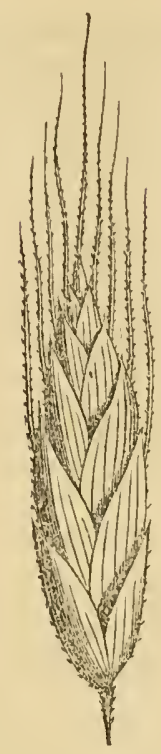

Fig. 53.

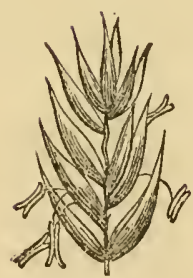

Fig. 55.

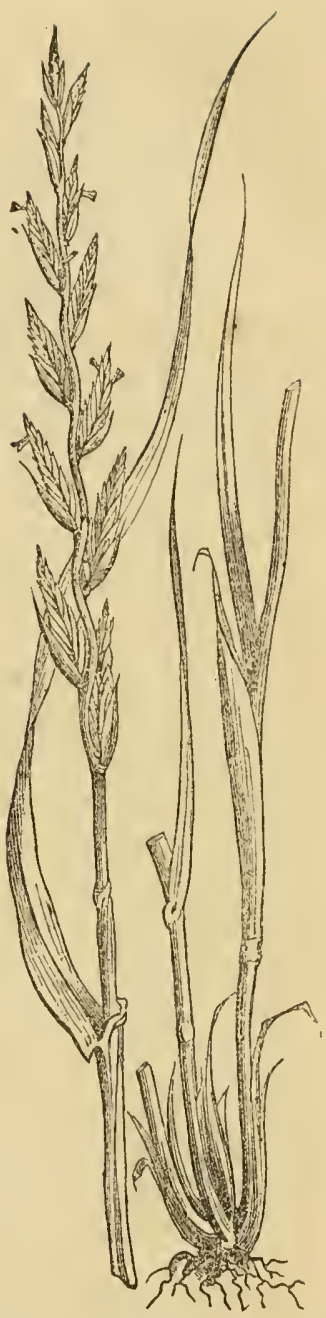

Fig. 64. Rye Gras.

and roughish on the inner, glume much shorter than the spikelet, flowers six to nine, awnless. Flowers in June. Shown in Fig. 54. Fig. 55 represents a magnified spikelet of this plant. This grass has had the reputation in Great Britain, for many years, of being one of the most important and rahuable of the cultirated grasses. It is probably much better adapted to a wet and uncertain climate, than to one subject almost annually to droughts, which often continue many weeks, parching up every 
green thing. There is, perhaps, no grass, the characteristics of which vary so much from the influences of soil, climate and eulture as perennial rye grass. Certain it is that this grass has been cultirated in England since 1674, and in the south of France from time immemorial. It is admitted to be inferior in nutritive value to orehard grass, (dactylis glomerata,) when green.

Whenerer it is eut for hay, it is necessary to take it in the blossom, ol very soon after, since otherwise it becomes hard and wiry, and is not relished by stock of any kind; and it changes very rapidly after blossoming, from a state in which it contains the greatest amount of water, sugar, \&e., and the least amount of woody fibre-into the state in which it possesses the least amount of water, sugar, \&c., and the greatest amount of woody fibre and other insoluble solid matter. A specimen analyzed about the 20th of June, and found to contain $81 \frac{1}{4}$ per cent. of water and $18 \frac{3}{4}$ per cent. of solid matter, was found only three weeks later to contain only 69 per eent. water, and 31 per cent. solid matter. It is undonbtedly a raluable grass, and worthy of attention ; but it is not to be compared, for the purposes of New England agriculture, to Timothy or to orehard grass. It produces abundance of seed, soon arrives at maturity, is relished by stock, likes a variety of soils, all of which it exhausts ; lasts six or seren years, and then dies out.

Italian Rye Grass, (lolinm italicum,) has been recently introduced into this State, and is now undergoing experiment which will assist in determining its value for us. It differs from perennial rye grass in the florets having long, slender awns, and from bearded darnel, (lolium temulentum,) in the glumes being shorter than the spikelets. This differenee will be manifest on reference to Fig. 56, and Fig. 57, which represents a magnified spikelet. It turfs less than the perennial rye grass, its stems are higher, its leares are larger and of a lighter green, it gives an early, quick and successive growth till late in the fall.

To say that it is, or would be, the best grass in our climate and on our soils, would be altogether premature; but it has the credit abroad of being equally suited to all the climates of Lurope, giving more abundant erops, of a better quality, and better relished by animals than the perennial rye grass. It is one of the greatest gluttons of all the grasses either cultivated 


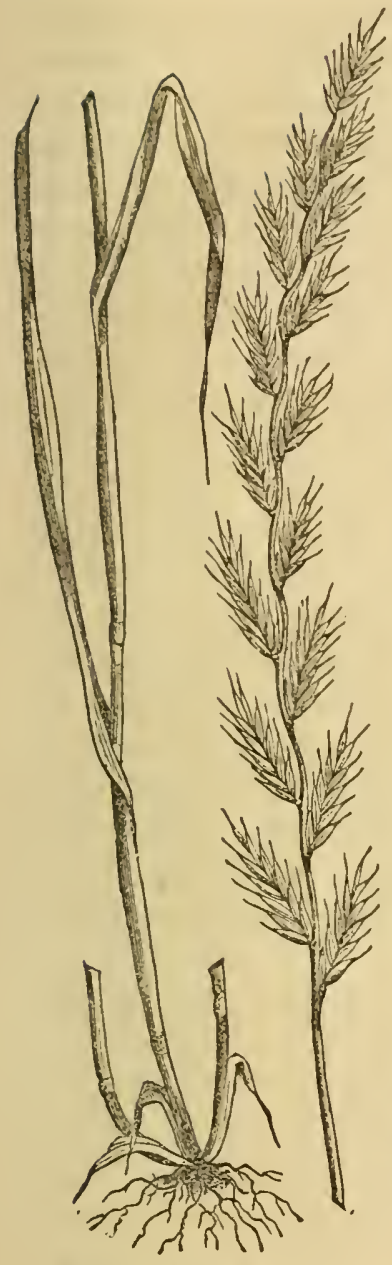

Fig. 56. Italian Rye Grass.
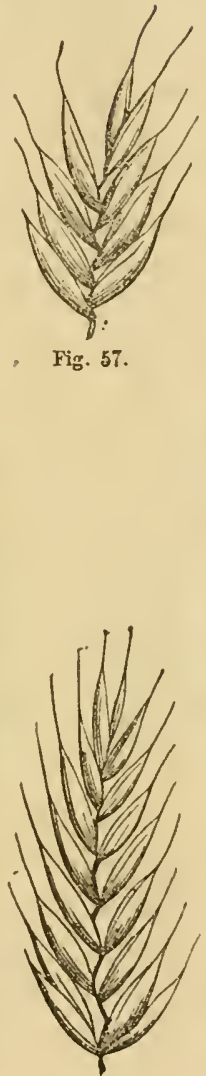

Fig. 59.

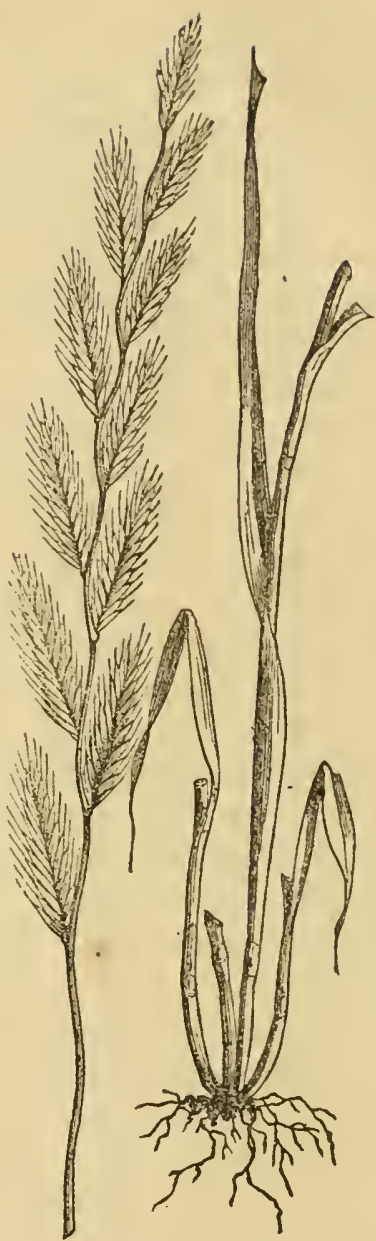

Fig. 58. Many-flowered Darnel.

or wild, and will endure any amount of forcing by irrigation or otherwise, while it is said to stand a drought remarkably well. The soils best adapted to it seem to be moist, fertile and tonacious, or of a medium consistency; and on such soils it is said to be one of the best grasses known to cut green for soiling, affording repeated luxuriant and nutritive crops. I hare not seen enough of it to speak from personal observation or experience of the comparative profit of this grass and Timothy for cultivation here, but its comparative mutritive ralue is well 
known from the thorough and reliable analyses of Prof. Way. By these it appears that 100 parts of Timothy grass, as taken from the field, contain 57.21 per cent. of water, 4.86 per cent. of albuminous or flesh forming principles, 1.50 per cent. of fatty.matters, 22.85 per cent. of heat producing principles, such as starch, gum, sugar, \&c., 11.32 per cent. of woody fibre, and 2.26 of mineral matter or ash, while 100 parts of Italian rye grass taken from the same kind of soil and in the same condition, green, contained 75.61 per cent. of water, 2.45 of albuminous or flesl forming principles, .80 of fatty matters, 14.11 of heat producing principles, starch, gum and sugar, 4.82 of woody fibre, and 2.21 of mineral matter or ash. Of these, the flesh forming principles, fatty matters, and heat producing principles, are, of course, by far the most important; and in all these our favorite 'Timothy very far excels the Italian rye grass, showing a nutritive ralue nearly double. Nor has the Italian rye grass any advantage orer Timotly or IIerds-grass in the dried state, though the difference is by no means so marked, the former dried at $212^{\circ}$ Fahrenheit containing 10.10 per cent. of flesh forming principles, the latter 11.36; the former containing 3.27 per cent. of fatty matter, the latter 3.55; the former containing 57.82 per cent. of heat forming principles, the latter 53.35 .

There are 432,000 seeds in a pound of Italian rye grass and from thirteen to eighteen pounds in a bushel.

The Bearded Darnel, (lolium temulentum, is sometimes found in our grain fields, with its glume equalling the five to seven flowered spikelets, and awn longer than the flower. Its grain is poisonous-almost the only instance known among the grasses.

The Many-Fowered Darnel, (lolium multiflorum,) is, perhaps, the most showy species of rye grass, cultivated. It is but very rarely, if ever, met with here, though it was introduced from France to England about thirty years ago, and is cultivated to some extent. Fig. 58 shows the appearance of this grass, and Fig. 59 a magnified spikelet. It is very nearly allied, if not identical with Italian rye grass.

Couch Grass, Quitci Grass, Twitci Grass, Dog Grass, Chandegr Grass, \&c., (triticum repens.) The chicf generic marks of this grass are, three or several flowered spikelets, 
compressed, with the flat side towards the rachis ; glumes nearly equal and opposite, nerved, lower palea like the glumes eonvex on the back, awned from the tip, upper flattened, stanens three; mostly annuals, but others are perennials, to which the couch grass belongs. The specific characters of couch grass are, roots creeping cxtensively, stem erect, round, smootl, from one

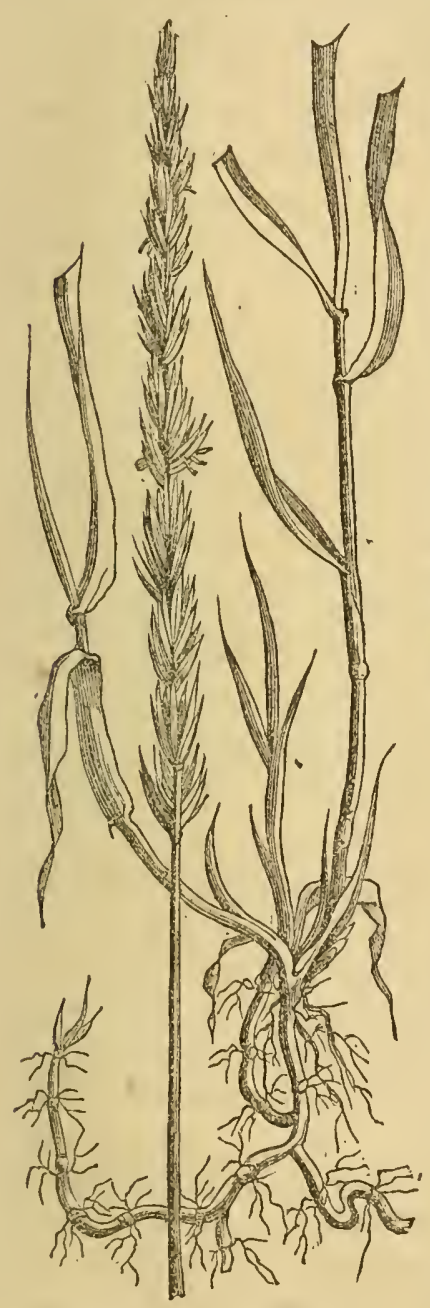

Fig. 60. Couch, or Twitch Grass.

to two or two and a half feet high, striated, having five or six flat leaves with smooth, striated slieaths; the joints are smooth, the two uppermost very remote, leaves dark green, acute, upper one broader than the lower ones, roughish, sometimes hairy on the inner surface, smooth on the lower

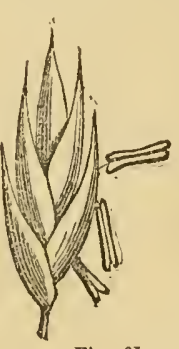
half. Inflorescence in spikes. Flowers in June and July. Introduced from Europe. (Figs. (i0 and 61.)

This plant is generally regarded by farmers as a troubleFig. 6i. some weed, and efforts are made to get rid of it. Its long, ereeping roots, branching in every direction, take complete possession of the soil and imporerish it. When green, however, it is very much relished by cattle, and if eut in the blossom it makes a mutritions hay. Dogs eat the leaves of this grass and those of one other species for their medicinal qualities in exciting romiting. I lave seen acres of it on the Connecticut River meadows, where it had taken possession and grew luxuriantly, and is called wheat grass, from its resemblance to wheat. It goes in different parts of the State by a great 
variety of names, as Quake grass, Quack grass, Squitch grass. It is important to destroy it if possible, and the means of doing it will be alluded to on a subsequent page.

Squirrel-TaIl Grass, (hordeum jubatum,) is widely diffused over our salt marshes. Its specific characters are a slender stem, smooth, about two feet high, with rather short leaves, and low, lateral, abortive, neutral flowers on a shor't pediccl, short amed, the perfect flower bearing an extremely long awn about the length of the similar hairy glumes, all spreading. It is common on moist sands and marshes on the sea shore. Flowers in June.

The common two-rowed barley, (hordeum distichum,) belongs also to the same genus as well as the common four or six-rowed barley, (hordeum vulgare.)

Lyme Grass, Wild Rye, (elymus virginicus,) is frequent along the banks of rivers. Its generic characteristics are two to four spikelets at each joint of the rachis, all fertile, each one to seven flowered, glumes both on one side of the spikelet, paleæ two, lorrer one usually awned, mostly peremial, some species annual.

Specific description: Spike upright, dense and thick on a short peduncle usually included in the sheath; two or three spikelets together, two or three flowered, smooth, shortly awned, stamens three, stems stout, from two to three feet high, leaves broad and rough. Flowers in July and August. Of no special value as an agricultural grass.

Canadian Lyae Grass, (elymus canadensis.) Spike rather loose and curving at the extremity, spikelets mostly in pairs of three to five, long awned, rough, hairy flowers, the lance awlshaped glumes, tipped with shorter awns, stem three to four feet high, root creeping, leaves broad, flat, linear, sheaths smooth and ligule short. Flowers in August. It is common on the banks of rivers.

Slender Hairy Lyme Grass, (elymus striatus,) is sometimes found in rocky woods and on the banks of streams, as the most slender and smallest flowered species of this genus. It flowers in July, and is so rare and of so little value as an agricultural grass, as not to need further description.

Upright Sea Lyme Grass, (elymus arenarius.) This grass, which much resembles beach grass, grows from two to five 
feet high, with a perennial long creeping root, stem erect, round, smooth, leares long, narrow, hard, greyish, pointed, grooved, rolled in, smooth behind and rough on the inner surface. It flowers in July. Differs from the common beach grass in having a short obtuse ligule, and spikelets without footstalks, of three or four florets, while beach grass has a long and pointed ligule, and spikelets with footstalks, and of only one floret.

Sinclair calls this grass the sugar cane of Great Britain. It contains a large quantity of saccharine matter, and it is probable that mixed with beach grass, as it is in Holland, it would be raluable to cut up and mix with common hay for winter feed. It is used precisely as beach grass is here, to prevent the encroachments of the sea, and to arrest the drifting of sand. It is not found growing wild in this country as beach grass is. I have cultirated it, by way of a partial experiment, on Nahant Beach, and it has been sown in other parts of the country.

BotTle-brusi Grass, (gymnostichum hystrix,) is found rather commonly in moist rocky woodlands, and along shaded banks of streams, and may be known by its loose upright spike and spreading spikelets, smooth sheaths and leares, smoothish flowers tipped with an awn three times their length. Flowers in July.

Wood Hair Grass, or Common Hair Grass, (aira flexuosa,) is a common grass on our dry and rocky hills, and road sides, and high upon Wachuset Mountain. The generic name is the Greek aira, darnel, or tares, and its characteristics are, two flowered spikelets, in an open diffuse panicle; flowers both perfect, shorter than the glumes, hairy at the base, lower palea three to fire nerved, awned on the back, grain oblong, smooth.

Specific characters: Stems slender, one to two feet high, nearly naked, leares dark green, often curved, bristle-formed, branches of the panicle hairy, spreading, mostly in pairs, lower palea slightly toothed, awn starting near the base, bent in the middle, longer than the glumes, which are purplish-perennial. Flowers in June. This plant is sometimes found 3,500 feet abore the lerel of the sea. Sheep eat it readily. Of no ralue for cultiration. Fig. 62 represents this grass in blossom, and Fig. 63 a magnified flower of it. It contains when dry but .63 per cent. of nitrogen.

Hassock Grass, (aira caspitosa,) also belongs to this genus 
aira. Stems crect, round, roughish, in close tufts, leares flat, lincar, acute, with roughish striated sheaths, upper sheath longer than its leaf, panicle pyramidal or oblong, large, at first drooping, afterwards erect, with branches spreading in every direction; awn barely cqualling the palca, outer palea of lower floret shorter than the glumes, membranous, jagged or four-toothed on the summit, hairy at the base, with slcnder awn rising from a little above the base, and extending: scarccly abore the palea. Distinguished from aira flexuosa in the awn of the lower floret not protruding beyond the glumes of the calyx. In aira flexuosa the awn of the lower floret protrudes more than onc-third its length beyond the gilumes.

It has an unsightly look in fields and pastures, on account of its growing in tufts or clusters or hassocks. Cattle seldom touch it. Prefers stiff or marshy bottoms, where the water stands. Junc.

Water Hair Grass,

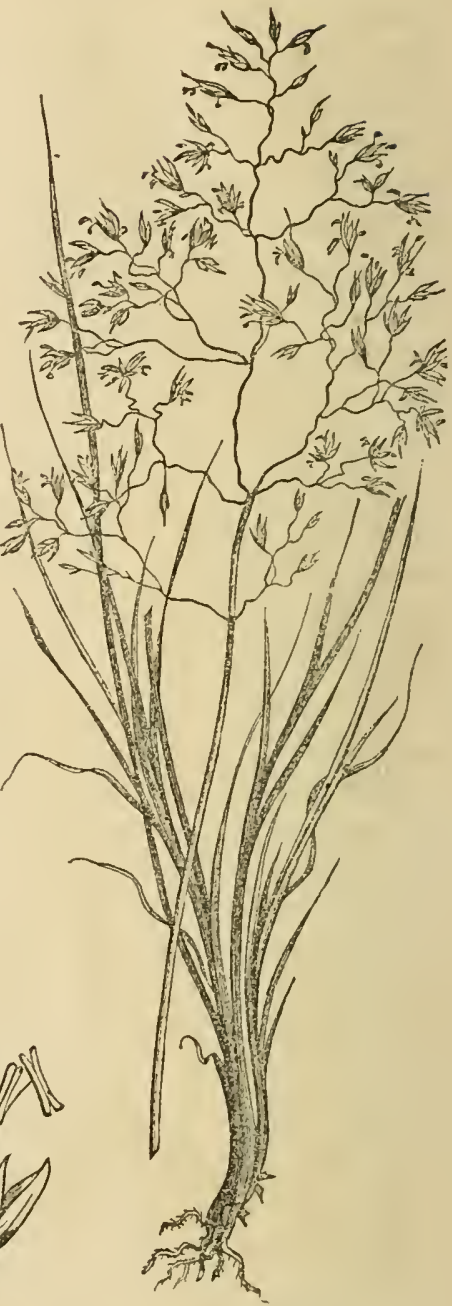

Fig. 63. Fig. 62. Wood IIsir Grass.

(aira aqnatica.) Fig. 61. This grass $\mathrm{Mr}$. Curtis calls the sweetest of the British grasses, and equal to any foreign one. Its stems and leares, when green, have a sweet and agrceable tasto like that of liquorice. Water fowls are said to be very fond of the seeds and the firesh green shoots. Cattle also eat it very readily. It is strictly an aquatic, but can be cultivated on imperfectly drained boirs and muddy bottoms. Not common. It flowers in July. 


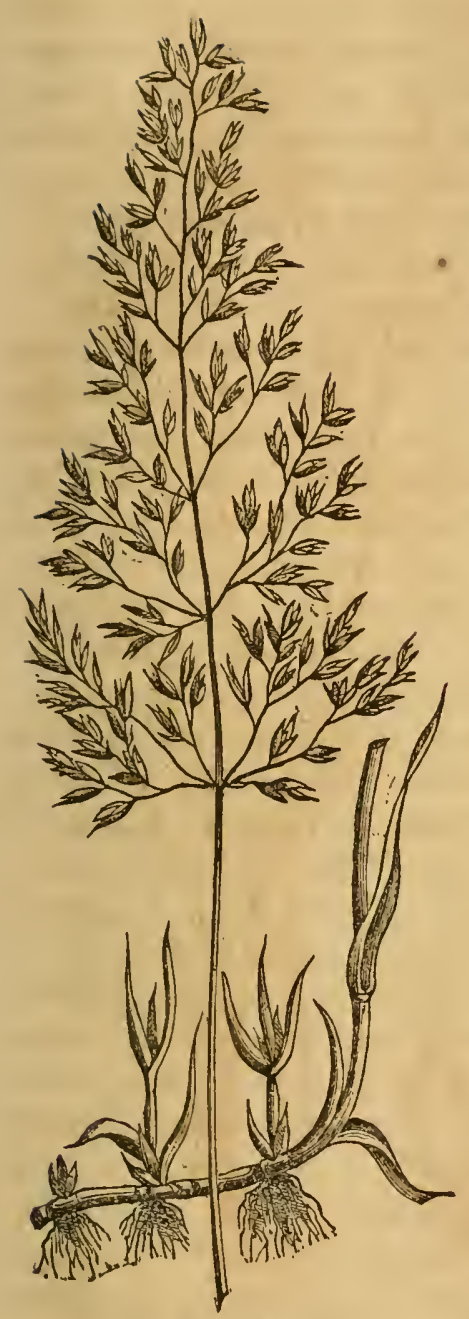

Fig. 64. Water Ilair Grass

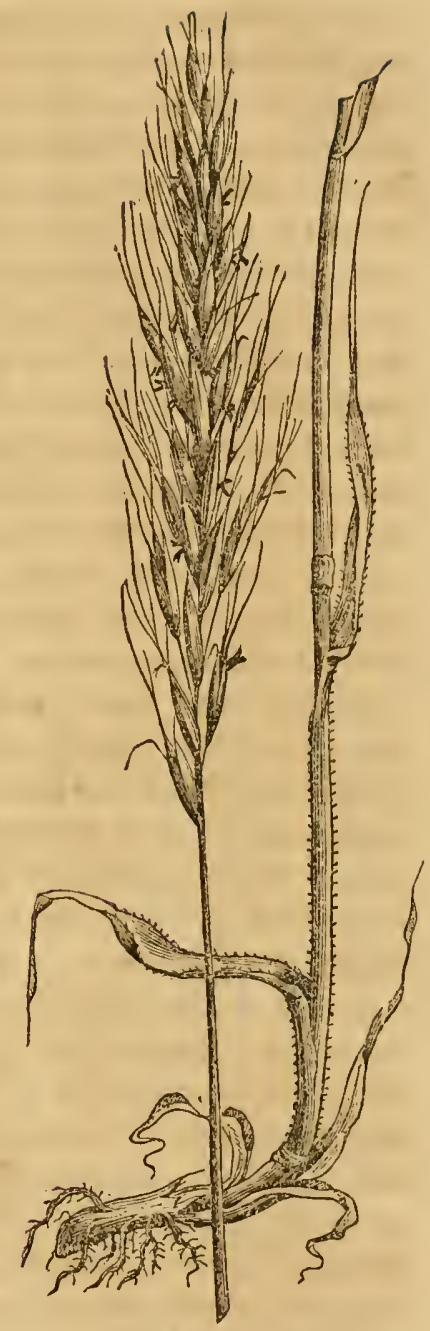

Fig. 65. Downy 0at Grass.

Wild Oat Grass, White Top, (danthonia spicata,) is common in dry, sunny pastures, with a stem one foot high, slender, with short leaves, narrow sheaths, bearded; panicle simple, spikelets scren flowered, lower palea broadly orate, loosely hairy on the back, longer than its awl-shaped tecth-perennial. Flowers in June. It is called white top in some localities, but is not the grass most commonly known by that name-the agrostis alba. 
Downy Persoon, (trisetum mollis,) is a grass with dense panicles, much eontracted, oblong or linear, awn bent or diverging, lower palea compressed, keeled, leaves flat and short; found on rocky river banks and mountains, about one foot high. It flowers in July. Of no agricultural value.

The Downy OAт Grass, (trisetum pubescens,) is a very hardy perennial grass, naturalized on chalky soils, and on such soils its leaves are corered with a coating of downy hairs which it loses when eultivated on better lands. It is regarded as a good permanent pasture grass on account of its hardiness and its being but a slight impoverisher of the soil, and yielding a larger per cent. of bitter extractive than other grasses grown on poor, light soils. It is therefore recommended abroad as a prominent ingredient of mixtures for pastures. It flowers early in July. Fig. 65 represents this plant as it appears in blossom. Formerly classed as avena pubescens.

Meadow Oat Grass, (avena pratensis, Fig. 66,) is a perennial grass, native of the pastures of Great Britain, growing to the height of about eighteen inches. It furnishes a hay of medium quality. Flourishes best on dry soils. Flowers in July. Figs. 67 and 68 represent the flowers of this grass magnified.

The Yellow OАT Grass, (avena favescens, now generally classified as trisetum flavescens,) can scarcely, perhaps, be regarded as naturalized here. It is a perennial plant of slow growth and medium quality, furnishing a hay containing about 1.79 per cent. of azote or nitrogen; suitable for dry meadows and pastures. It is sometimes regarded as a weed, growing about eighteen inches high. It fails if cultivated alone, but suceeeds with other grasses, and is said to be the most useful for fodder, of the oat grasses. It grows best with the crested dog's tail and sweet scented vernal. It contains a larger proportion of bitter extractive than most other grasses, and for that reason is recommended by some English writers as a valuable pasture grass. It flowers in July. Fig. 69 represents this grass, and Fig. 70 a flower of it magnified.

Tall Meadow Oat Grass, or Tall Oat Grass, (arrhenatherum avcnaceum,) is the avena elatior of Linnæus. Specific characters: Spikelets open panieled, two flowered, lower flower staminate, bearing a long bent awn below the middle of the back; leaves flat, acute, roughish on both sides, most on the 


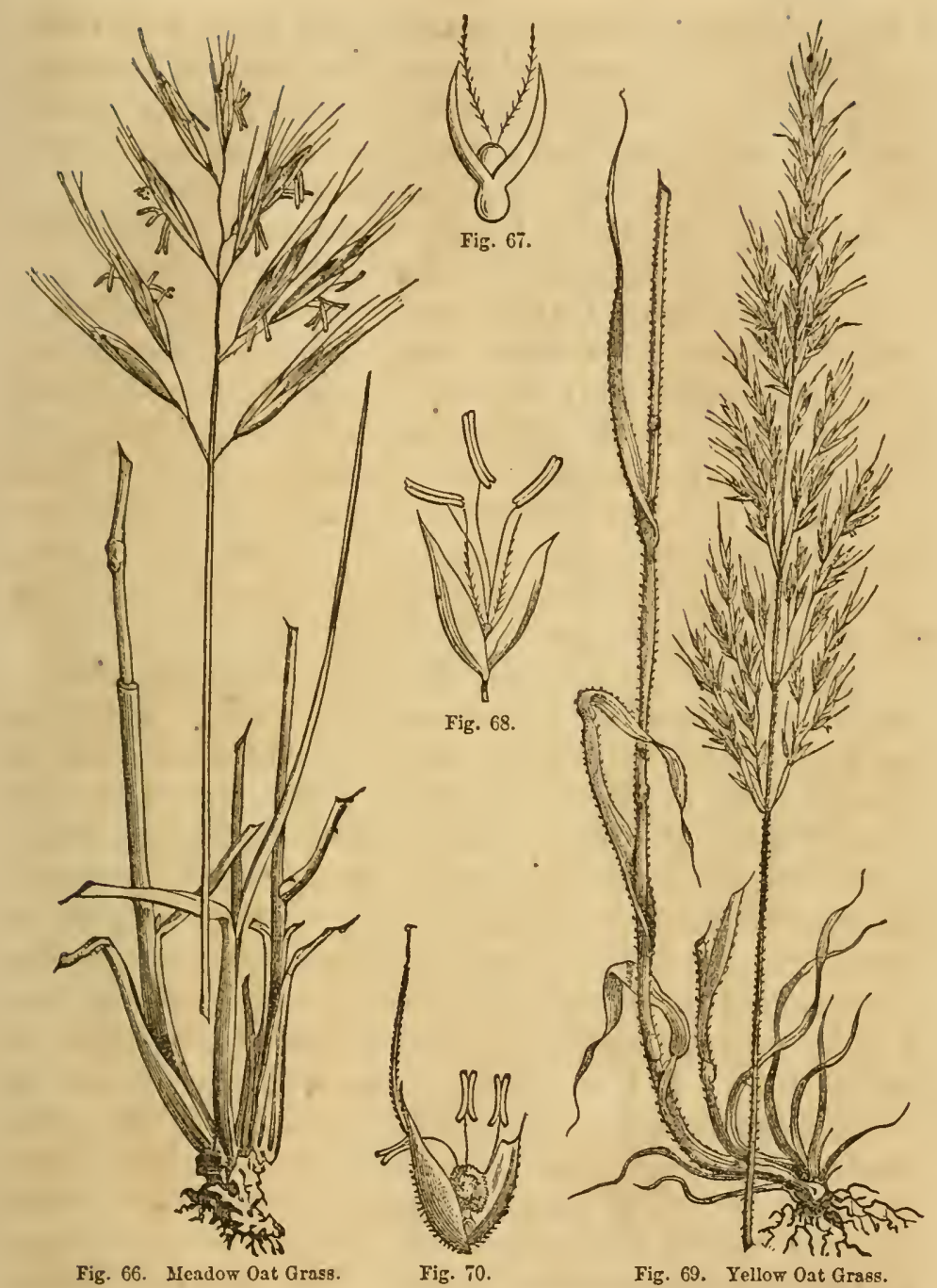

inner; panicle leaning slightly on one side, glumes rery unequal; stems from two to three feet high, root perennial, fibrous, sometimes bulbous. It is readily distinguished from other grasses by its haring two florets, the lower one having a long awn rising from a little abore the base of the outer palea. Introduced. Flowers in June and July. Shown in Fig. 71. A magnified spikelet is seen in Fig. 72 .

This is the Ray grass of Franee. It produces an abundant 


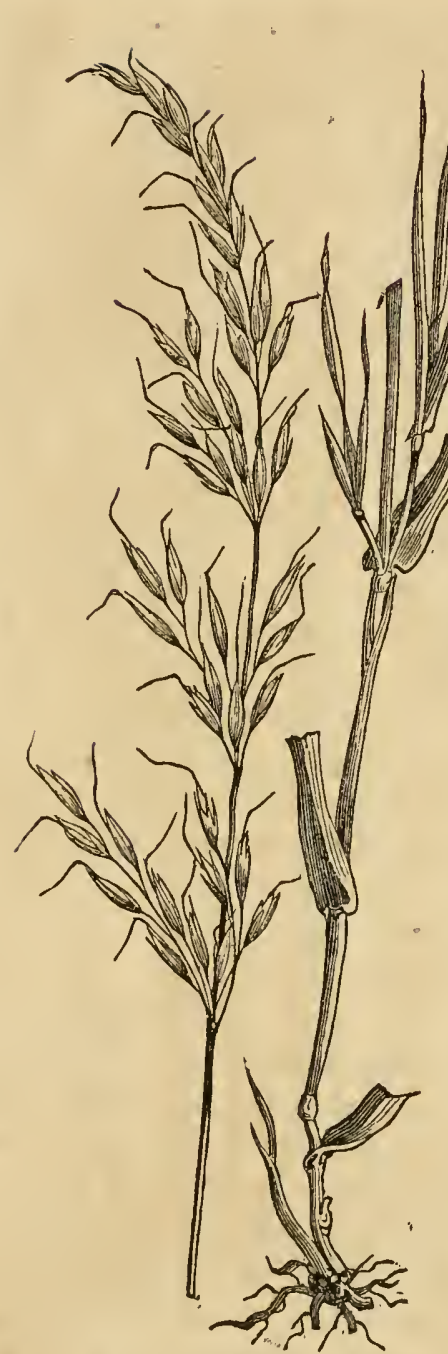

Fig. 71. Tall Meadow Oat Grass.

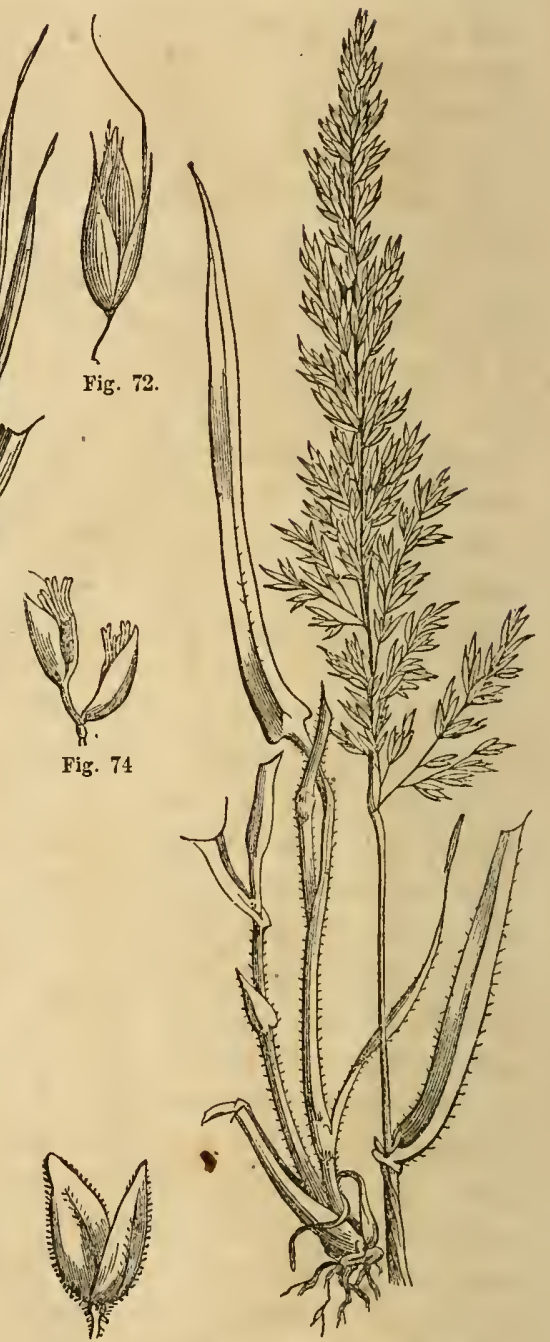

Fig. 75. Fig. 73. Meadow Soft Grass.

supply of foliage, and is valuable either for hay or for pasture, and has been especially recommended for soiling purposes, on account of its early and luxuriant growth. It is often found on the borders of fields and hedges, woods and pastures, and sometimes very plenty in mowing lands. After being mown it shoots up a very thick aftermatl, and on this account, partly, is regarded as nearly equal for excellence to the common foxtail, (alopecurus pratensis.) 
It grows spontancously on deep, sandy soils, when once naturalized. It has been eultivated to some extent in New England, and is esteemed by those who know it, mainly for its early, rapid and late growth, making it very well calculated as a permanent pasture grass. It will sueceed on tenacious clover soils.

Meadow Soft Grass, Velvet Grass, (holcus lanalus,) has its spikelets crowded in a somewhat open panicle, and an awn with the lower part perfectly smooth. The generic characters are, two flowered spikelets jointed with the pedicels, glumes boat-shaped, membranaceous, inclosing and exceeding the flowers; lower flower perfect, its lower palea awnless and point-less, upper flower staminate only, bearing a stout bent awu below the apex. Stamens three; grain free, slightly grooved.

This species grows from one to two feet high, stem erect, round, root perennial, fibrous, leaves four or five, with soft, downy sheaths, upper sheath much longer than its leaf, inflated, ligule obtuse, joints usually four, generally covered with soft, downy hairs the points of which are turned downwards; leaves pale green, flat, broad, acute, soft on both sides, covered with delicate slender hairs. Inflorescence compound panicled, of a greenish, reddish or pinkish tinge; lıairy glumes, oblong, tipped with a minute bristle. Florets of two paleæ. Flowers in June. Introduced. In Fig. 73 is seen a drawing of this grass, and in Figs. 74 and 75, its flowers magnified.

This beautiful grass grows in moist fields and peaty soils, but I have found it on dry, sandy soils on Nantucket, and specimens have been sent me from Boxford and other places where it grow on upland fields, and was eultivated with other grasses. It is productive and easy of cultivation. It is of but little value either for pasture or hay, cattle not being fond of it. When once introduced it will readily spread from its light seeds which are easily dispersed by the wind. It does not merit cultivation except on poor, peaty lands, where better grasses will not succeed. This grass loses about .63 of its weight in drying, and the hay contains about 1.92 per cent. of nitrogen.

The Creeping Soft Grass, (holcus mollis, Fig. 76,) not yet naturalized here. It is of no value, and is regarded as a troublesome weed. Distinguished from the preceding by its 


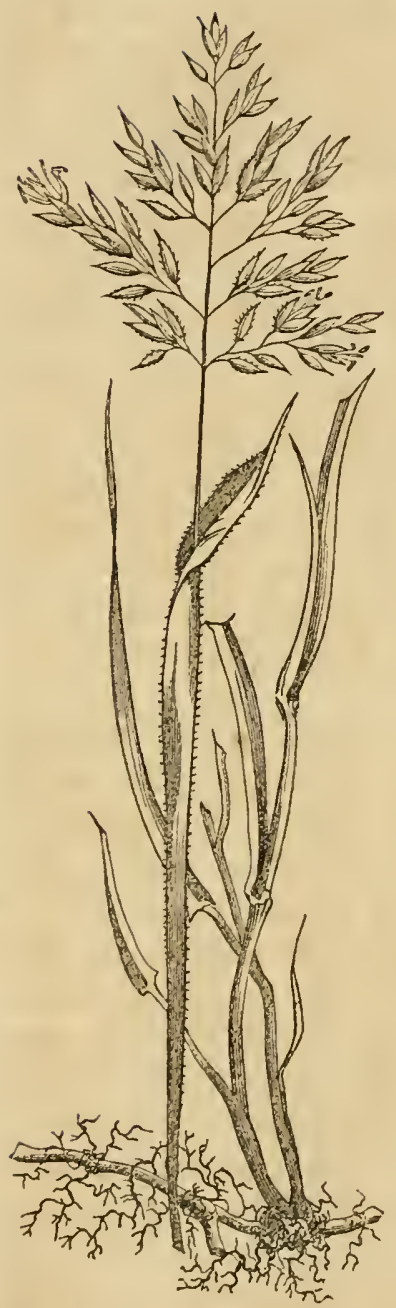

Fig. 76. Creeping Soft Grass.

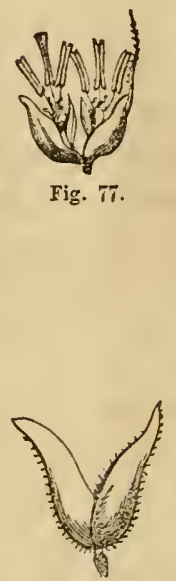

Fig. 78.

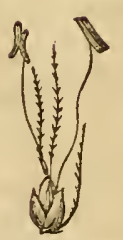

Fig. 80.

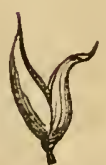

Fig. 81.

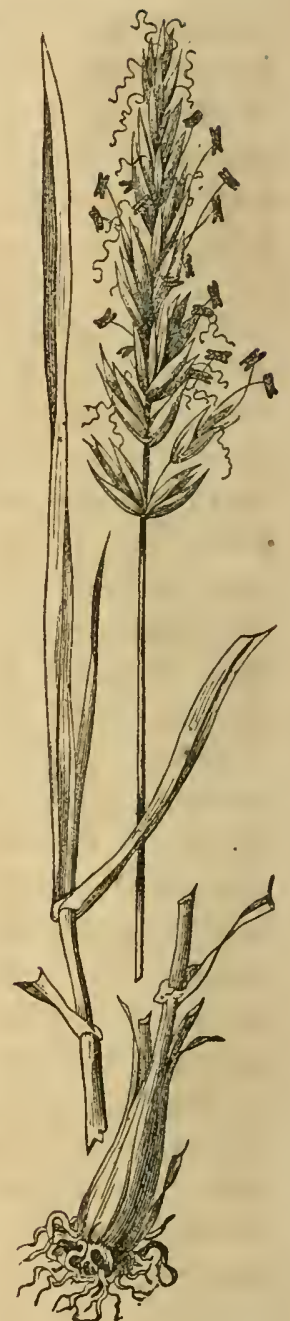

Fig. 79. Sweet-scented Ternal.

awned floret and its creeping root. The flowers of this grass are seen magnified in Figs. 77 and 78.

Seneca Grass, or Vanilla Grass, (hierochloa borealis, ) has spikelets three flowered, flowers all with two palex, branches of the panicle smooth; grows from twelve to eighteen inches high. Stems erect, round, smooth, panicle somewhat spreading, rather one sided, leares short, broad, lanceolate, rough on the inner side, smooth behind; spikelets rather large. 
Grows in wet meadows. Flowers in May. Common and generally diffused, but of no ralue for cultivation, on account of its powerful, creeping roots and very slight spring foliage. It derived its generic name, hierochloa, holy grass, from two Greek words, signifying sacred grass,--from the fact that it was eustomary to strew it before the doors of the churches on festival and saint's days, in the north of Europe. In Sweden it is sold to be hung up orer beds, where it is supposed to induce sleep.

Sweet Scexted Vernal Grass, (anthoxanthum odoratum.) Specific characteristics: Spikelets spreading, three flowered, lateral flowers neutral, with one palea, hairy on the outside and awned on the back; glumes thin, acute, keeled, the upper twice as long as the lower; seed ovate, adhering to the palea which incloses it; root perennial. Flowers in May and June. Stcms from one and a half to two fect high. Introduced from Europe. This grass is seen in Fig. 79 .

This is onc of the earliest spring grasses, as well as one of the latest in the autumn. It is almost the only grass that is fragrant. It possesses a property peculiar to this species, or possessed by only a few others, known as coumarin. It is said to be this which not only gives it its own aromatic odor, but imparts it to other grasses with which it is cured. The green leaves when bruised give out this perfume to the fingers, and the plant may thus be known. The grass has but little value of itsclf, its nutritive properties being slight; nor is it much relished by stock of any kind, but as a pasture grass on almost all soils, and with a large mixture of other grasses, it is very valuable for its early growth, and this gives it the character of a permanent pasture grass.

It is not uncommon in our pastures and road sides, growing as if it were indigenous. I have found fine specimens of it on dry soils at Nantucket and elsewhere.

The aftermath or fall growth of this beautiful grass is said to be richer in nutritive qualities than the growth of the spring. Though it is pretty generally diffused orer the country, it is only on certain soils that it takes complete possession of the surface and forms the predominant grass in a permanent turf, as it is said to do in some sections around Philadelphia. The flavor of the spring butter sold in that city is ascribed by some 
to the prevalence of this grass. There seems to be nothing inconsistent in this supposition, since it is well known that disagreeable flavors are often imparted to the milk and the butter by the substances taken as food by the cow, as turnips, for instance, or cabbages, or cauliflowers; and if an objectionable flavor may be imparted by one substance, it is reasonable to suppose an opposite flaror may be given by another. Much, of course, depends on the manufacture; as poor butter is found in the Philadelphia market, as in any other, while as good could be, and is found, in the Boston market as any in the world. The best butter, I learn on inquiry, is as expensive in the former city as elsewhere, while it is true that a high price will command and obtain a good article wherever the art of butter making is at all understood.

I am informed by Dr. Emerson, of Philadelphia, to whom I am indebted for valuable specimens of this grass, that he has made experiments in flavoring other grasses with a slight addition of benzoic acid in the form of an essence, provious to feeding them out to milch cows, and that the flavor of the best Philadelphia spring butter was thus imparted to the butter made from them.

A curious and beautiful peculiarity is exhibited in the seeds of this grass, by which they are prevented from germinating in wet weather after approaching maturity, and thus becoming abortive. The husks of the blossom adhering to the seed when ripe, and the jointed awn by its spiral contortions, when affected by the alternate moisture and dryness of the atmosphere, act like levers to separate and lift it out from the calyx even before the grass is bent or lodged and while the spike is still erect. If the hand is moistened and the seeds placed in it, they will appear to move like insects, from the uncoiling of the spiral twist of the awns attached to them.

The flowers of the sweet scented vernal grass are seen in Figs. 80 and 81 . There are 923,200 seeds in a pound, and eight pounds in a bushel. It camnot be said to belong to the grasses useful for general cultivation.

Refd Canary Grass, (phalaris arundinacea.) Generic characteristics: Spikelets crowded in a dense or spiked panicle, perfect flower flattish with two neutral rudiments of flowers, one 
on each side at its base, awnless, two shining palex, closely inclosing the smootl, flattened grain; stamens three.

Specific description : panicle very slightly branched, clustered, somewhat spreading when old, but not so much generally, as appear's in Fig. 82 ; glumes wingless, rudimentary florets hairy,

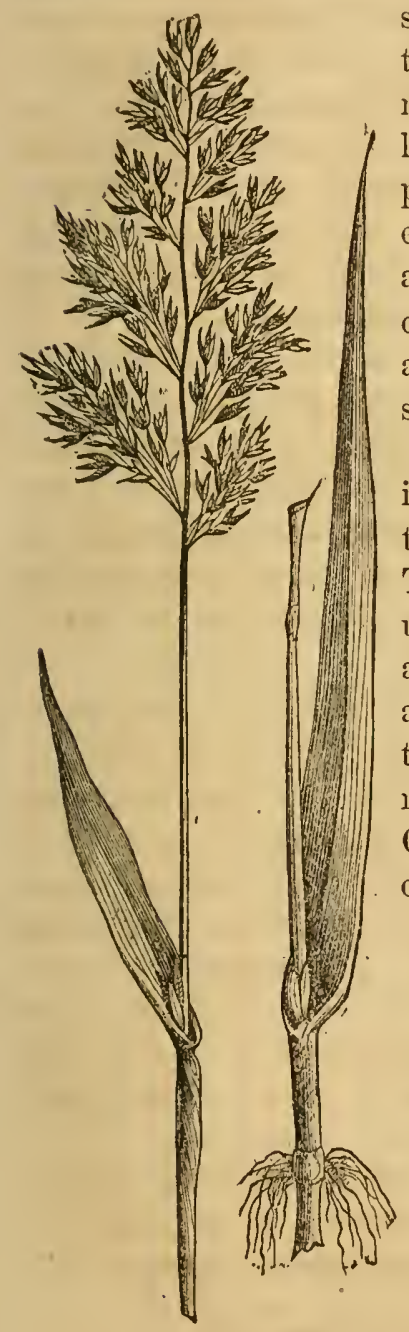

Fig. 82. Reed Canary Grass. stem round, smooth, erect, from two to seren feet high, leaves five or six in number, broad, lightish green, acute, harsh, flat, ribbed, central rib the most prominent, roughish on both surfaces, edges minutely toothed, smooth, striated sheaths. Flowers in July. Grows on wet grounds by the sides of rivers and standing pools, best suited to somewhat tenacious soils.

A beantiful variety of this species is the Ribbon or Striped Grass of the gardens, familiar to every one. The reed canary grass grows in the utmost luxuriance at the State Farm, at Westborough, and produces a large and early crop. It will bear cutting two or three times in a season, but if not cut carly, the foliage is coarse. Cattle are not fond of it at any stage of its growth, but if cut carly and

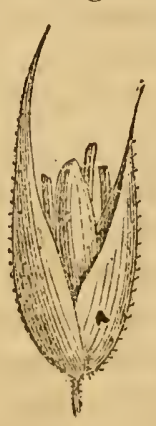

Fig. \&3. well cured, they will eat it in the winter if they can get nothing better. For some experiments with this hay in comparison with others, see p. 61 .

This grass is common in low, rich soils where the water is either standing or sluggish, and is not unfrequently produced by transplanting the roots of the striped grass into suitable soils. In one instance within my knowledge, it came in and produced an exceedingly heavy crop, simply from roots of ribbon grass 
which had been dug up from a garden and thrown into the brook to get them out of the way. Several other instances of a smilar nature have also come to my notice. One farmer has propagated it extensively in his wet meadows by forcing the ripe seed panicles into the mud with his feet. As the stripe of the ribbon grass is only accidental, dependent on location and soil, it constitutes only a variety of the reed canary grass and loses the stripe when transferred to a wet and muddy soil.

The cut, Fig. 82, was made from a specimen too far adranced to show this grass as it ordinarily appears; the panicle or head is too spreading and not sufficiently long. I have fine specimens with panicles three times as long as appears in the drawing, and more in the shape of a spike of Timothy.

To ascertain the exact nutritive qualities of this grass when cured as hay, a careful analysis has been made at my request, by Prof. E. N. Horsford, of Cambridge, with the following result: Of water, the specimen contained 10.42 per cent.; ash, 5.31 per cent.; nitrogen, .55 per cent.; nitrogenous ingredients, flesh forming principles, 3.53 per cent.; woody fibre, starch, gum, sugar, \&c., 80.73 per .cent.* It will be seen by

* The following are the details of this valuable analysis :-

1st. Of the Leares stripped from the Culms or Stalks;

2d. Of the Stalks from which the Leaves and Joints were removed; and

3d. Of the Joints.

Weight of different portions of the Plant.

I. Leaves of four Stalks, air-dried, weighed, . . . . . $\quad 2.9239$ \}

Grammes. Av. Gr's.

II. " " " " . . . . . . 2.8740

2.8989

I. Four Stalks, without Joints, or Leaves, air-dried, weighed, . . 4.1167 \}

II. " " " " " . . 3.2018$\}$

3.6592

I. Joints of four Stalks, air-dried, weighed, . . . . . . $\quad .5161\}$

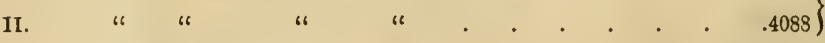

Average Total,.$\quad \cdot .0205$ Grammes.
Average wcight of Stalks with Leaves and Joints, $\quad 1.7551$ Grammes.

Water Determination.

1. Of the Leaves, .9234 grammes lost at a temperature of $212^{\circ} \mathrm{Fah} . .1014$ grammes-equal to 10.98 per cent.

II. Of the Stalks, 1.9836 grammes lost at $212^{\circ}$ Fah. .1902 grammes-equal to 9.58 per cent.

III. Of the Joints. 2.4529 grammes lost at $212^{\circ}$ Fah. .2630 grammes-equal to 10.72 per cont.

\section{Ash Determination.}

I. Of the Leaves, air-dried, 2.9239 grammes gave .2590 grammes $\mathbf{A s h}$-equal to 8.85 per cont.

II. Of the Stalks, air-dried, 4.1167 grammes gave .1475 grammes $A s h$-equal to 3.58 per cent.

III. Of the Joints, air-dried, .5161 grammes ga e .0181 grammes Ash-equal to 3.50 per cent. 
reference to a subsequent page, containing analyses by Prof. Way, that this grass is very far inferior to many of the grasses examined by him. The panicles of this grass if allowed to stand after the time of flowering, become filled with ergot, or long, black spurs, issuing from between the glumes, and occu-

None of the above ashes effervesed with acid, indicating the absence of carbonates. They gave but the faintest reaction for lime. Indeed microscopie, as well as chemical examination, showed the Ash to be eomposed almost entirely of Silica.

\section{Nitrogen Determination.}

I. Of the Leaves, 1.4370 grammes, air-dried, gave .2600 grammes of Platino-Chloride of Ammonium-equal to 1.13 per cent. of Nitrogen, and 7.21 per cent. of Nitrogenous ingredients.

II. Of the Stalke, air-dried, 1.6009 grammes gave .0205 grammes Platino-Chloride of Ammo- nium-oqual to .08 per cent, of Nitrogen, and .51 per cent. of Nitrogenous ingredients.

III. Of the Joints, air-dried, 2.4529 grammes gave .1789 grammes Platino-Chloride of Ammouium-equal to .45 per cent. of Nitrogen, and 2.87 per cent. of Nitrogenous ingredients.

The preceding results, in tabular form, appear as follows :-

Relative Weight of different portions.

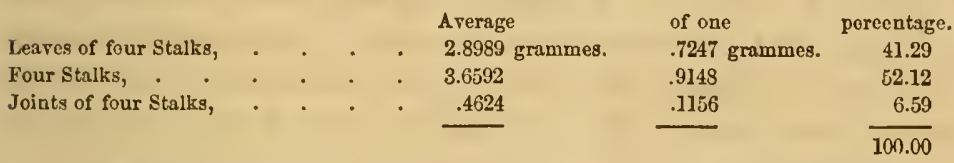

Average weight of ene plant without the roots, . . . . 1.7551 grammes.

\section{Percentages.}

\begin{tabular}{|c|c|c|c|c|c|}
\hline cares, & $\begin{array}{l}\text { Water. } \\
10.98\end{array}$ & $\begin{array}{l}\text { Ash. } \\
8.85\end{array}$ & $\begin{array}{c}\text { Nitrogen. } \\
1.13\end{array}$ & $\begin{array}{l}\text { Nitrogenous } \\
\text { Ingredients.* } \\
7.21\end{array}$ & $\begin{array}{c}\text { Woody Fibre, Starch, } \\
\text { Sugar, \&c. } \\
72.96\end{array}$ \\
\hline talk & 9.58 & 3.58 & .08 & .51 & 86.33 \\
\hline Joints, & 10.72 & 3.50 & .45 & 2.87 & 8291 \\
\hline
\end{tabular}

For comparison as to the relative nutritive valnes, there follow some determinations made of hay from several localities by Henneberg and Thos. Way.

\begin{tabular}{|c|c|c|c|c|c|c|}
\hline Hay analyzed gav & & & & Nitrogen. & Nitrogenou & Is Ingredie \\
\hline For Leaves, & . & 1.13 & ) & & & \\
\hline For Stalks, & & .08 & 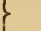 & 5.71 per cent. $\uparrow$ & 3.53 & per cont. \\
\hline For Joints, . & - & .45 & J & & & \\
\hline Clover,. & . & - & . & 1.57 & 10.01 & " \\
\hline Hay, No. 1, s & saline soil & . & . & 1.49 & 9.51 & " \\
\hline "No. 2, & May, & • & . & 1.39 & 8.87 & " \\
\hline ". " J & June, & - & - & 1.49 & 9.51 & “: \\
\hline " $"$ & October, & . & . & 1.70 & 10.85 & " \\
\hline
\end{tabular}

It will be seen that some of the samples contain nearly three times as much of Nitrogenous Ingredients as the sample submitted for examination, and it will be inferred from this consideration that, other things being equal, the hay at the head of the list is decidedly inferior in nutritive value.

\footnotetext{
* Three parts of Nitrogen correspond with 19.16 parts of Nitrogenous Ingredients, as regetable albumen, fibrin and casein.

$\dagger$ Estimated according to percentages of different parts.
} 
pying the place of grain. This, if there were no other reason, would be sufficient to determine that it should be eut at or before the time of flowering. I have never seen rye worse affected than my specimens of this grass are. The effects of this mysterious disease are well known. The noxious power it exerts on the system of animals which receive eren a small portion of it, is oftentimes dreadful, producing "most horrible gangrenes, rotting of the extremities, internal tortures and agonizing death; it has been known to slough and kill not a few human beings who have accidentally or inadvertently eaten grain or flour infected with it."

The flower of the reed canary grass is shown in Fig. 83. The variety called striped grass, (colorata, is exceedingly hardy and may be propagated to any extent by dividing and transplanting the roots. In moist soil it spreads rapidly and forms a thick mass of fodder which might be repeatedly cut without injury, though it is of little value for feeding stock.

The Comnon Canary Grass, (phalaris canariensis,) is eultivated in gardens, and to some extent in fields and waste places for the sake of the seed for the canary bird. It has a spiked, oval panicle, glumes wing-keeled; rudimentary flowers smooth and half the length of the perfect one. Flowers in July and August.

Millet Grass, (millium effusum, is found growing commonly in moist, shady woods, mountain meadows, and on the border's of streams. Panicle widely diffuse, compound, glumes ovate, very obtuse, leaves broad and flat, thin, root perennial, flower oblong. Flowers in June. Introduced. Of no value for cultivation, the foliage possessing but slight nutritive qualities. The seeds are sought by birds. It will thrive transplanted to open places.

Hairy Slender Paspalum, (paspahum setaceum, has an erect or decumbent, slender culm, from one to two feet high, leaves and sheaths hairy, spikes sleuder, smooth, mostly solitary on a long peduncle, spikelets narrowly two rowed. Flowers in August. It is found on sandy ficlds and plains near the coast, and is rather common.

Slender Crab Grass, (panieum filiforme,) is another species of the subgenus digitaria, or finger grasses, and resembles the last somewhat, but the upper glume equals the flower, while the 
lower is nearly wanting, and the spikes are more erect. It flourishes on sandy, dry soils, especially near the coast. Flowers in August. Of no value for cultivation.

Sirootri Crais Grass, (panicum glabrum,) resembles the last, with the spikes digitate, three to four, spreading, rachis flat and thin, spikelets oroid. It is common in cultivated grounds, waste places, and on sandy fields. Flowers in August and September. A troublesome weed.

Finger Grass, Common Crab Grass, (panicum sanguinale.) The panie grasses are widely spread and common over the State. The generic cliaracters are, two flowered panicled spikelets, flowers with or without awns, glumes two, lower one short or minute, the upper long as the fertile flower, upper flower perfeet, closed, flattish, awnless, stamens three.

The stems of the finger grass are from one to two fect high, erect, spreading, leares and sheaths hairy, spikes four to fifteen, digitate, upper glume half the length of the flower, lower one small. This grass grows on waste or neglected cultivated grounds and gardens, and yards, and is generally regarded as a troublesome weed. Introduced. Flowers from August to October.

Agrostis-like Panic Grass, (panicum agrostoides,) differs from the preceding species in having the stems flattened, upright, two feet high, leaves long, sheaths smooth, spikelets on the spreading branches crowded and one sided, ovate, oblong, acute, purplish. It is common on wet meadows and borders of rivers. Flowers in July and August.

Prolific Panic Grass, (panicum proliferum,) grows on brackish marshes and meadows, and is common along the coast. It sometimes appears on dry places. Cattle are fond of it. It differs from the preceding in having culms thickened, sucenlent, branched and bent, ascending from a procumbent base, and spikelets appressed, lance-oval, of a pale green color. .

Hair Stalked Panic Grass, (panicum capillare,) grows in sandy soils and cultivated fields every where. Its culm is upright, often branched at the base, and forming a tuft, sheaths flattened, rery liairy, panicle pyramidal, liairy, compound and very loose, spikelets seattered on long pedicels, oblong, pointed. Flowers in August and September.

Tall Sirooth Panic Grass, (panicum virgatum.) Stems 
upright, three to five feet high, leaves very long, flat, panicle large, loose and compound, branches spreading when grown, and drooping, spikelets scattered, oval, pointed, glumes usually purplish. Grows pretty commonly in moist, sandy soils, and flowers in August.

Broad-Leaved Panic Grass, (panicum latifolium.) This is a grass with a perennial, fibrous root, and stem from one to two feet high, and leaves broad, long, taper-pointed, smooth or slightly downy, branches of panicle spreading,. spikelets long, obovate, downy. Flowers in June and July. It is common in moist thickets and woods. Of no value for cultivation.

The Hidpen-flowered Panic Grass, (panicum clandestinum,) the Yellow Panic Grass, (panicum xanthophysum, the Polymorphus Panic Grass, (panicum dichotomum, the Fetv-Flowered Panic Grass, (panicum depauperatum, the WartyFLowered Panic Grass, (panicum verrucosum,) are sometimes found, the first, in low thickets and along the banks of rivers, not very common; the second, on dry and sandy soils, pine plains, rare ; flowers in June; the third, in dry and low grounds, not very common, flowers in June and July; the fourth, on dry, sandy hill-sides, more common than the preceding; the fifth, in sandy swamps, near the coast. None of these are valuable for cultivation, nor are they troublesome as some of the preceding species of panic are, on account of their places of growth.

Barn Grass, or Baryyard Grass, (panicum crus-galli,) is more common. Its spikes are alteruate and in pairs, sheaths smooth, rachis bristly, stem from two to four feet high, stout, erect, or somewhat procumbent, leares lalf an inch broad, panicle dense, pyramidal, glumes acute, awn variable in length and sometimes wanting, outer palea of the neutral flower, usually awned; one or two rarieties have rough or bristly sheaths. It grows on moist, rich or manured soils and along the coast in ditches. Flowers in August, September and October.

- Some experiments have been made to cultivate this common species in the place of millet, to cut for green fodder. It is relished by stock and is very succulent and nutritive.

Hungarian Millet, Moha de Hongrie, (panicum germanicum,) has been cultivated to some extent in this State, from 
seed received through the Patent Office. It is an annual forage plant introduced into France in 1815, where its cultivation has become considerably extended. It germinates readily, withstands the drought remarkably, remaining green even when other regetation is parched up, and if its development is ariested by dry weather, the least rain will restore it to vigor. It has numerous succulent leaves which furnish an abundance of green fodder, very much relished by all kinds of stock.

It flourishes in somewhat light and dry soils, though it attains its greatest luxuriance in soils of medium consistency and well manured. It may be sown broadcast and cultivated precisely like other varicties of millet. This millet is thought to contain a somewhat higher percentage of nutriment than the common millet, though I am not aware that it has been analyzed. A practical farmer of Worcester county says of it: "I have raised the "Moha de Hongrie," on a small scale only. In my garden it has grown thick and fine.

"As it is a leafy plant and remains green until its seeds mature, I think it may prove valuable for fodder, both green and dry. It grows and matures in about the same time as the common millet.

"I have now one bushel of seed, grown on six square rods. This quantity will enable me to test it practically, another season."

This plant is seen in Fig. 84, which gives a correct representation of it.

The Bristly Foxtail, (setaria verticillata,) is a grass sometimes, though rarely, found about farm houses. It has cylindrical spikes two or three inches long, pale green, somewhat interrupted with whorled, short clusters, bristles single or in pairs, roughened or barbed downwards, short. Not cultivated.

Bottle Grass, sometimes called Foxtail, (setaria glauca.) This is an annual with a stem from one to three feet high, leaves broad, hairy at the base, sheaths smooth, ligule bearded, spike two to three inches long, dense, cylindrical, bristles six to cleven in a cluster', rough upwards, perfect flower wrinkled. The spike is of a tawny or dull orange yellow. when old. Flowers in July. It is common in cultivated grounds and barnyards. Introduced.

The Grees Foxtail, sometimes also called Bottle Grass, 
(setaria viridis,) has a spike cylindrical, more or less compound, green, bristles few in a cluster, longer than the spikelets, flower perfect, striate lengthwise and dotted. It is common in cultivated grounds.

The Bengal Grass, sometimes called Millet, (setaria italica,) also belongs to this genus. It has a compound spike, thick, nodding, six to nine inches long, yellowish or purplish, bristles two or three in a cluster. Introduced from Europe.

Bur Grass, or Hedgehog Grass, (cenchrus tribuloides,) is somewhat common on sandy soils on the coast, or ne the salt water, where the spikes are whitish. It is regarded as a troublesome weed on account of its prickly burs. Flowers in August.

Gama Grass, or Sesane Grass, (tripsacum dactyloides,) though not often found in this State is one of the largest and most remarkable grasses, though not one that would be considered of any value where better could be had. Its stalk is from four to seven eet ligh, and the leaves look not very unlike those of Indian corn. Grows on moist soils near the coast. Flowers in August.

Finger-SPIKed Wood Grass, (andropogon furcatus.) of this genus about sixty species are known to botanists. But $\mathrm{few}$ of these are indigenous to this country. Its generic characteristics are, a neuter or staminate lower flower, glumes and palex often wanting, upper flower perfect, glumes awnless, lower palea awned. Flowers in panicles and spikes.

Specific description: Stems four feet high, leares nearly smooth, spikes digitate or generally by threes and fours, lower 
flower awnless; the spikelets are roughish, downy, awn bent. Flowers in September. This grass is eommon on sterile soils, rocky banks and hill-sides. Not cultirated.

Purple Woon Grass, or Broour Girass, (andropogon scoparius,) and the Ixdmax Grass, or Wood Grass, (andropogon mutans,) grow on sterile and dry, barren soils, and sandy plains, and are common, though of no value for cultivation. They flower from July to September.

The Chinese Sugar Cane, (sorghum saccharatum? not yet finally elassified.) Paniele opcn or spreading, spikelets two or three, the lateral ones sterile, the middle or terminal one fertile, glumes tough and hard, sometimes awnless, stamens three.

Specific description: Stem from six to fifteen feet high, aceording to the ssil on which it grows, erect, smooth, leaves linear, flexuous, gracefully eurring down at the ends, resembling Indian eorn in its es.".r. growth, and broomcorn, to which it is nearly allied, at matcrity. Flowers in a paniele at the top, at first green, ehanging through the shades of riolet to purple, when more adranced. See Fig. 85, taken from a plant somewhat orer seren feet in heiglit.

This plant has lately been introduced and used both for forage and the manufacture of sugar and molasses or sirup. In some instanees it has been used for making vinegar, brandy and other liquors. As it is a true grass, and is at present exeiting considerable interest throughout the country, it is proper to notice it in this connection.

The genus sorghum embraces orer thirty species, most of whieh originated in Asia, where some of them have been eultivated time out of mind. Specimens of the sorghum saccharatum were introduced into Franee by means of the seed, about six or eight years ago, where they hare been eultivated with considerable success. So far as we know, this speeies is the best and most raluable for cultivation for the various purposes alluded to. Most of the seeds first used in this country were obtained from France, through the efficient ageney of the Patent Office, at Washington, having been first cultirated in the spring of 1855.

Any positice assertions with respect to the value of this plant, would, perhaps, be premature, but I have had rery good 
opportunities of observation upon it, and have met many individuals from different latitudes who have cultivated it with great success, and numerous experiments upon it are still in progress, which will determine its relative ralue and its modes of cultiration. It is, undoubtedly, very rich in saccharine matter in all latitudes within the geographical range of Indian corn. It has been said that the percentage of sugar decreases somewhat in the higher latitudes; but this does not seem to have been established as a fact, and the opposite conclusion, will, rery probably, be arrived at, even though the percentage of sugar found to be crystallizable should be greater in more tropical regions.

The plant grown in Massachusetts the past year contained about twenty-three per cent. of sugar, while that grown in the District of Columbia contained but fourteen per cent. And this accords with what we know of Indian corn, since it is pretty well established that the corn grown in high latitudes is richer in saccharine matter than that grown at the South. The meal of northern com is also better, and will bring at all times a considerably higher price in the market.

Of the Chinese sugar cane about seven-eightlss of the whole plant consist of juice, especially when grown in a southern latitude where the juice is somewhat more abundant, the cane being more succulent there; and we may readily credit the statement that rinegar has been made from this juice at the rate of fifteen hundred gallons to the acre.

When cut for sugar the most farorable time is just after it has passer the blossom, or when the seed is "in the milk," and if raised for this purpose the time of planting should be later than that of Indian corn. The leares are stripped off and the stalk is crushed in any convenient mills or rollers, though more suitalle mills will undoubtedly be constructed.

Should it be found on more careful trial to be equal to what is reported of it, it will make an entire revolution in the sugar growing interests of the country, and thus become a plant of great national importance. It is said that the crop of sugar raised in Louisiana has gradually decreased from nearly five hundred thousand hogsheads in 1853, to less than one hundred thousand, in 1856, while the price of sugar and molasses-a greater amount of which is consumed in this, than in any other 


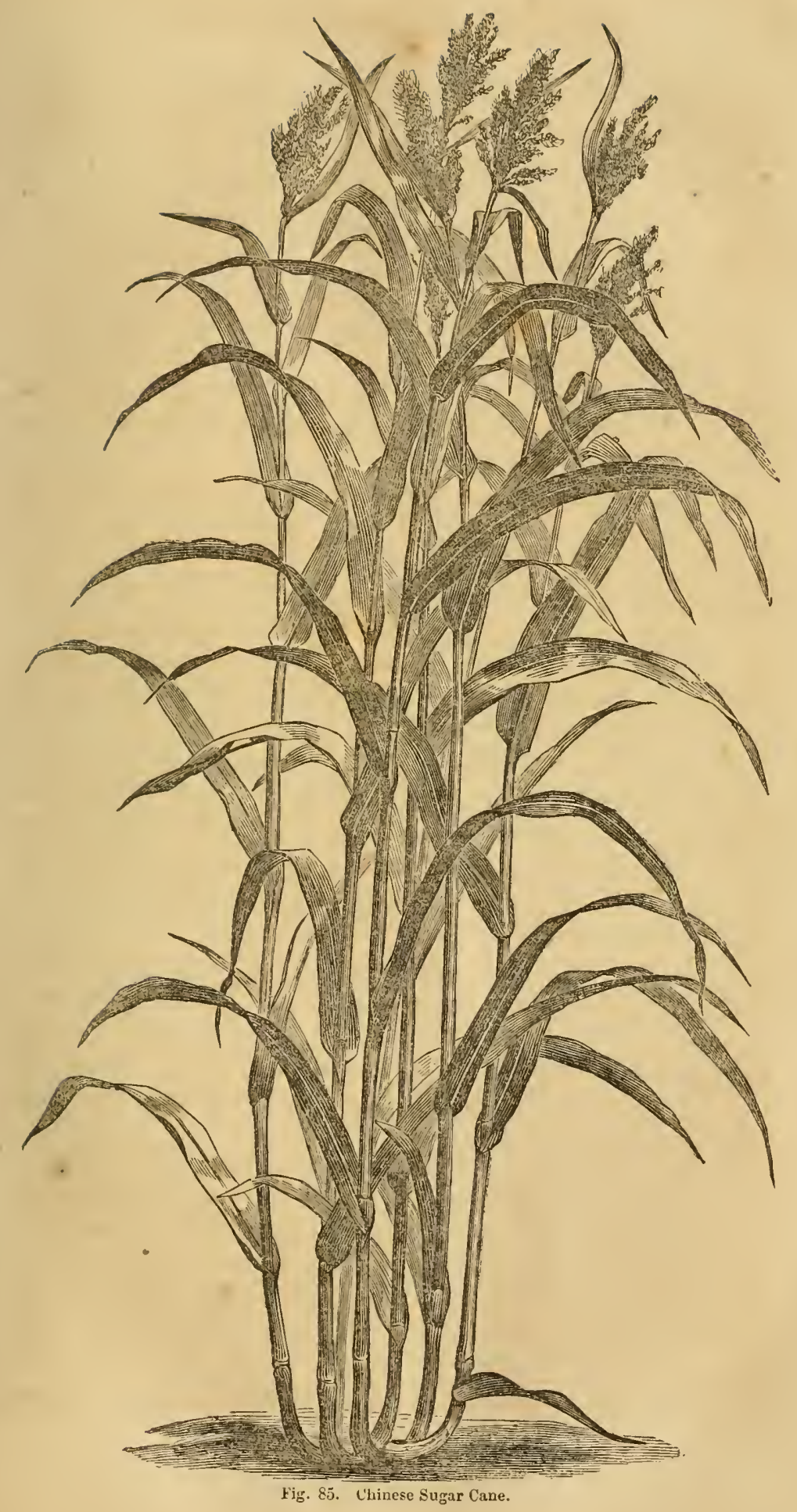



country on the globe, in proportion to the population-is loudly calling the attention of farmers and planters to its production; and the Chinese sugar cane is regarded by some as a substitute for the species of sugar cane most commonly eultivated there, the saccharum officinarm.

But I propose to speak of it in this connection mainly as a forage plant, though it may prove perfectly practicable and profitable to cultirate it for the purpose of making sugar and molasses. Some years ago the practice of sowing Indian corn in drills for the purpose of cutting up green for fodder, was recommended by a progressive agriculturist, and though at first ridiculed, it soon came to be planted in small patches of a few rods square, by practical farmers here and there, till now it is regarded as almost an indispensable crop, not only to carry a stock of cattle through a serere summer drought, when our pastures are short and dry, but to eut and cure in large quantities for winter use. The weight and value of an acre of fodder is very great. Of late years there has been an inclination to use sweet corn for this purpose, under the supposition that it possessed a larger quantity of saccharine matter in its stalks and leares than the yellow varieties. When the use of sweet corn was first recommended, it was said that cattle were so much more fond of it than of yellow corn, that they would select its stalks if tied up in a bundle with the stalks of yellow corn. The same is now asserted of the Chinese sugar cane, and as it comes to me rery well authenticated, I see no reason to doubt it.

Of the economy of the culture of corn to feed out green in the manmer alluded to, there can be no question, and no thrifty and prudent farmer thinks of neglecting it; for if we suffer from drought, as we are liable to every season, he is sure to regret it. Now if a substitute of superior ralue can be found, of as easy and simple cultivation, every farmer will arail himself of it. Whether this substitute will be found in the Chinese sugar cane, remains, perhaps, to be proved; but so great has been its suceess thus far as to lead us to anticipate its adoption and extensive cultivation for that purpose. In one case authentically reported, nearly ten tons of fodder were raised on an acre, cut up and cured, and weighed three months after cutting. This is not at all surprising when.we consider 
that even larger yields of Indian corn have been and are frequently obtained, when raised, ent and cured in the same manner.

When grown for fodder, two or three cuttings may be obtained from it, the first being made just before the time of blossoming, when the plant immediately starts up with a vigorous growth and renews its leaves, and sends up its flowering panicles with great rapidity. No less than five enttings were obtained in Florida during the last year, but the seasons in more northern latitudes would not admit of so many. It is well known that Indian com will shoot up the second time in the same manner, when once eut or eaten down while green.

This plant grows best in a dry soil and hot sun, in both of which it can be accommodated as far north as New England. It should be planted at or just after the time of Indian corn, and it will mature its fruit in about one hundred days from the seed. For the purposes of sugar making it is best cultivated on rather poor, warm soils, but for feeding out to fattening animals, it should be cultivated on richer ones. If raised for sugar it is better harrested somewhat late in the season, when the temperature ranges from $45^{\circ}$ to $55^{\circ}$, when it is not so apt to suffer from the acetous fermentation to which it will be liable if cut earlier. But if raised mainly for the seed, it would be well to plant it somewhat earlier in the spring, in which case it might be cut earlier in the fall. Though the seed is now exccedingly dear on account of its scarcity and the extensire demand for it, yet it is estimated that it can be raised at the price of oats, fifty and sixty bushels to the acre having been obtained without any extraordinary care. The seed ean be made into bread or into a beverage resemuling chocolate, or fed to poultry and other farm stock.

'The Chinese sugar eane, if sown with a view to obtaining its seed, or to attaining its full and perfect development, should be cultivated in hills after the manner of planting Indian corn, and hoed and cultivated in the same manner; but if sown for fodder, it will be found to yield a more luxuriant crop in drills, as we cultivate Indian corn for that purpose. In the former case, one quart of seed will suffice for an acre as it tillers very much, each seed sending up several shoots or seed bearing stems; in the latter case, a larger quantity would be required. 
As a fodder plant it has been found not to increase the quantity of milk, milch cows fed upon it having fallen off very decidedly, while they rapidly increased in flesh, and the quality and richness of the milk was found to be improved. This may, therefore, be found to be an objection to its use with some, to whom the quantity is indispensable and the quality of no consequence; but even such may find it desirable to cure and feed it to cows in winter.

It was raised in Dorehester during the past year from seed raised there the year previous, which is conclusive proof that the seed can be ripened in this latitude so as to germinate, though for all practical purposes it is not material to us whether it will ripen here readily or not, if it is found to do so in the Middle States.

As already intimated, the results of experiments have been successful, and these experiments will be carefully repeated the coming season.

A farmer in the State of New York, whose communication appears in the volume of the Patent Office Report on Agriculture, for 1855, says: "The proper time for planting, I should say, would be the same as that of early corn, as I find it quite hardy, and stallss of it cut down the end of October made fresh shoots after two rather heary frosts, and still were good for feed. From twenty-five plants I obtained half a bushel of ripe seed.

"The mode of cultivation I would recommend, would be to. sow after the ground is well manured and deeply ploughed, in drills four feet apart, the plants two feet asunder in the drills, with not more than one plant in a place, as each sends up from four to six shoots. When the plants are well started, say a foot in height, turn orer the earth on each side with a plough, after which keep them clear of weeds with the hoe.

"When well cultivated and in good soil, the plant attains from ten to fourteen feet in height and produces excellent fodder from the root to the top. I believe a heavier weight of nutritious feed for all kinds of cattle can be procured from it in a giren space of ground, than from any other plant, and I think it will prove of great benefit to every section of the country where it is introduced, not only as a green feed during the hot months, but after being cut up and cured like the corn plant, 
its stalks may be steamed during the winter, and given to horses, oxen or cows, which will commence eating at one end and not leare them till entirely consumed. The seeds, also, I have no doubt, will prove valuable as a feed for poultry, as I find they eat them with avidity. I look upon this plant as of great value as a forage crop, and possibly, it may be profitably cultivated for sugar, as the juice contains nearly ten per cent. of saccharine matter as clear as crystal, and on a very small scale, beautiful clarified sugar was produced by my friend $D r$. Ray."

Other statements are equally unqualified in the expression of confidence in the value of this plant. I subjoin the following practical suggestions on the cultivation of it, from a valuable little manual by Mr. Hyde, of Newton Centre, who has experimented with it. He says :-

"Select a warm and dry soil, such as you would select for Indian corn.

Prepare your ground precisely as you would for corn, either by spreading your manure, or putting in hills,--about the same distance between the hills, where the ground is rich.

In planting, which should be done early, put into each hill six or eight seeds. Corer lightly with well pulverized soil,say, three-forthths to one inch deep; pull out all but four or five at second hoeing. If planted in drills, seed enough should be used so that after hoeing there may be a stalk to erery four or five inches; from a pound and a half to two pounds of seed should be used.

Cultivate and hoe as with corn; care should be taken that the ignorant do not hoe up the young plants, taking them for barn-grass, which they rery much resemble.

When the panicles appear they should be cut off of all that which is intended for sugar or sirup making.

When the plant has just passed into bloom, the stalk may be used for sirup, but will continue to grow better until the seed is in the milk-stage, or little later.

The stalks should be eut close to the ground, with a bill-hook or some such tool, and stripped of their leares, and the green, succulent top cut off, when they are ready for the mill; the leares and top may be fed green to cattle, or dried. 
The stalks sliould be passed through the mill twice or more, until most or all of the juice is expressed.

The juice should not be allowed to stand long after being expressed, but boiled at once, if possible. $\Lambda$ slow fire should be made under the kettle, - which should be of brass, or much better of copper,- and the juice should not be allowed to boil until the green seum has all been taken off. Lime-water may be used to aid in clarifying and to neutralize the acid; the exact quantity is not yet determined, but to every five gallons of juice, say from one to two teaspoonfuls of powdered lime, or the same dissolved in water, and strained, before being put into the juice.

When all the green seum has been removed, the fire may be increased, and the juice boiled down until nearly as thick as common molasses in hot weather, when, if intended for sirnp, it should be remored from the fire, for this completes the process: If intended for sugar, it should be allowed to boil longer, and until it will 'string into threads,' or present an appearance of bcing sufficiently boiled to grain, when it should be throwu off into troughs, or coolers, at once. I am not able to give exact information in regard to the time it should be boiled to crystallize readily. Further experiments will determine.

If made into sugar, it should be remored from the coolers to casks with holes bored in them, so that the molasses may drain off and leare the sugar dry, as it should be. These casks are generally placed on timbers, with a cement cistern underneath to hold the drippings, or molasses. After remaining in the 'purgery' until sufficiently drained, it comes out fit for sale, or use.

If cultirated exclusively for fodder, it should be planted as carly as the weather will allow, and quite as thick as storercorn. When the panicles appear, or even before, it may be cut either for soiling or for drying, and the roots will at once throw up another crop.

If it is desired, the juice may be fermented, like the juice of apples, being put into casks at the mill, and treated like cider.

'The hegass, or waste, may be dried and used for fuel, or' for making paper, or rotted down for manure.

If the storms should blow down the seed-cane, no fears need be cntertained, as it will remain weeks in that condition without 
injury. I must here eaution all persons who grow this eane against planting it in the vicinity of broomeorn, Dourah corn, or Guinea corn; for it readily mixes with these plants, and it would render the seed worthless for planting."

As already suggested, more accurate investigations are required to determine the relative importance of this plant for the various economical purposes alluded to. If it should be found, on chemical analysis, that the large percentage of saccharine matter in the plant consists of what is called glucose, a substance of comparatively little value, incapable of crystallization to any extent, instead of a saccharine substance capable of casy granulation, it would very materially affect the value of the plant for the purposes of sugar making, but could liardly affect its real value as a forage plant. This point will soon be determined.

If, as has been stated, it is found to be suitable for the manufacture of alcoholie liquors, it should, perhaps, be regarded by the plilanthropist as an important addition to our cultivated crops. It is well known that enormous quantities of our best grains are now withdrawn from their legitimate use as food for man, for the manufacture of these articles. Many distilleries use upwards of two thousand bushels of Indian corn or other grains, on an average, every day, and the consumption of grain for these purposes throughout the country is incredibly large.

The Chinese sugar cane will probably be found to be an exhauster of land, requiring large quantitios of the phosphates and silicates of the soil for the development of the hard coating of its stems. It has been estimated that nine tons of it to the acre would take from the soil fourteen hundred pounds of mineral substances. This would seem to indicate a dry, gravelly, or a sandy soil, as best suited to supply it wants.

Indian Grass, Wood Grass, (sorghtum nutans,) is a grass sometimes found on our dry, sterile soils, with a panicle oblong, somewhat compressed, from six to ten inches long, stem from three to five feet high, leaves linear, grayish, sheaths smooth, spikelets light brown and glossy, drooping when mature, hairy at the base, awn twisted. It flowers in August.

Indian Millet, (sorghtum vulgare, is a eultivated spocies and has several well marked varietios, one of which is the Broour- 
Cons. It is called Guinca corn in the West Indies, Dourah in Arabia, and Nagara in the north of China. It is sometimes used as a forage plant.

As already intimated, more than thirty species supposed to belong to this genus are known to have been introduced into France, though it is rery probable that a more accurate classification will distribute many of them among the other genera.

The tall eereal which has long been eultivated in the south of Europe and in Barbary, under the general name of sorghum, resembles Indian corn in quality, and is often called small maize. Its stems contain a pretty large per cent. of saccharine matter, and it is useful to cut green as a forage plant.

Indian millet, when raised on good soil and under farorable circumstances, is said to yield a larger quantity of sced to the acre than any other cereal grass known, not excepting even Indian corm. Its nutritive quality is nearly equal to that of wheat. The common millet is the panicum miliaceum.

Indan Conn, Matze, ( $z e a$ mais,) is a well known plant of American origin, a true grass, and one of the most beantiful and useful of this great family. Its value as a forage plant has already been alluded to in speaking of the Chinese sugar cane, and need not be dwelt upon here. Subject as we are, to the screrest droughts, which parch up and essentially injure our pastures, this plant has been found to be of the utmost importance to cut up green, affording an abundant and nutritious fodder, exceedingly succulent and greatly relished by cattle of all kinds, keeping them in good condition, while withont this or some similar substitute our stock would inevitably suffer.

The varieties cultivated for the purpose of fodder should be those with the largest and most succulent leaves. Some of the varicties of sweet corn are usually preferred, but on this point farther and more accurate investigations are greatly needed.

It is estimated that on an average from six to eight tons of dry fodder may be procured from an acre sown in drills and properly cultivated, and that this would be equal to about four or fire tons of good hay. This is a reasonable estimate, as far larger crops are often obtained.

The particular advantage of raising what are called forage plants, either to cut up green for soiling or to cure for winter use, over our ordinary mowing lands is, that they give on the 
same extent of land a far larger amount of nutriment for animals. They give this product immediately, or at least, in a very few montlis from the time of sowing, while permanent mowing lands, or the perennial grasses, require a great lengtlı of time to arrive at perfection, varying from one to four or five years. The amount of fertilizing materials drawn from the air and stored away in the soil by means of the roots, and capable of benefiting the crops of the sueceding year is very considerable, while, in the natural grasses, it remains under the turf and does not eome into use till the sward is broken and submitted to culture. We may choose for forage culture plants which start up early in spring and are capable of being used even before the natural grasses liave attained a size to make them partieularly valuable for grazing.

Besides, the mass of manure which may be made from the product of an acre of land by the use of forage plants, owing to the increased yield, over and above what would be obtained from the same acre in the natural grasses, is an item too rarely taken into the account.

Moreover the plants usually ealled forage plants, like the clovers, lucerne and green com fodder, may have some advantage over root culture, their expense being generally less, their product, dried, more easily stored, and kept with less danger of injury and decay, and the mode of feeding out to animals attended with less trouble.

RED Clover, (trifolium pratense.) We have givelı our whole attention, in the preceding pages, to what are strictly and properly called the natural grasses. We now eome to consider, very briefly, the artificial. Curious as it may appear, the artificial grasses were eultivated first in point of time, in England, the red clover having been introduced and grown there about the year 1633; sainfoin, 1651; yellow elover in 1659, and white clover about the year 1700 ; while not one of the natural grasses was cultivated till nearly a eentury later, with the exeeption of perennial rye grass, first cultivated in 1677. About the year 1759 the custom of sowing the chaff and seed dropped from the hay stack, along with the artificial grasses and rye grass began, and soon after-between 1761 and 1764-the cultivation of 'T'imothy and orchard grass was introduced from. Amcrica. The culture of the bent grasses, the slieep's feseue 
and the crested dog's tail, began soon after. In 1766, the London Society for the Encouragement of Arts offered premiums for the collection of the seeds of some of the grasses then found growing wild, such as the meadow foxtail, the meadow fescue, the sweet scented remal grass, \&e., and in 1769 the same society offered additional rewards for farther investigations and experiments on the culture and comparative value of the natural grasses. But little was done, however, till the experiments undertaken by the Duke of Bedford, in 1824.

In this country the extensive and practical cultivation of the natural grasses seems to have been commenced at an earlier date than in England, for Jared Eliot, writing about the year 1750 , speaks of the culture of Timothy as having been adopted sometime preriously. Indeed, the necessities of our rigorous climate compelled attention to this branch of husbandry soon after the establishment of the colony, in 1620. The climate of England, on the other hand, admitted a greater degree of reliance on the wild luxuriance of nature, and this mode of management was brought over by the first settlers and attempted for some years, the few cattle they had being kept on poor and miscrable swale hay, or often upon the hay obtained from the salt marshes. The death of their cattle from starration and exposure was of rery common occurrence, and not unfrequently the furmer lost his entire herd. The treatment of animals now, as they were treated during the whole of the first century of the colony, would make the owner liable to prosecution for cruelty. This treatment was, in part, owing to the porerty of the settlers, but more, probably, to the ideas and practices in which they had been carly trained in a different climatc. Fortunately for the poor dumb beast a more enlightened poliey now governs the mass of men, and this policy has led to greater care and attention to the cultivation of the grasses.

But in this country, the culture of the natural grasses takes the precedence in point of time from the canses already indicated, and the minds of men are so influenced by the routine of ordinary practice, that the introduction of clover in the early part of the last century met with great prejudice, which is now nearly, if not quite extinct.

Red elover, though not properly included in the family of 
grasses, is now not only extensively cultivated, but is found to be one of the most raluable and cconomical forage plants. It belongs to the pulse family, or leguninosa, which includes the larger portion of forage plants called artificial grasses, in distinction from the gramineæ, the true, and often called the natural grasses. The generic name, trefoil, or trifolium, is derived from the Latin tres, three, and folium, a leaf; and the genus can generally be very readily distinguished by the number and arrangement of its leares in three leaflets, and flowers in dense, oblong or globular heads.

Specific description: Stems aseending, somewhat hairy, leaflets oval or obovate, often notched at the end and marked on the upper side, with a pale spot, heads ovate and set direetly upon the stalk instead of upon branches. This species is regarded as by far the most important of the whole genus. It lias sported into a number of varieties, one of which is biennial, another perennial, the latter by long cultivation becoming biemnial, while the former, - as is true of most biennial and many annual plants,--assumes, to some extent, the cliaracter of a perennial and can be made to last three or four years or even more, by simply preventing it from rumning to seed. This plant is seen in Fig. 86, its leaf is shown in Fig. 87, and its fruit magnified in Fig. 88.

The introduction of elorer into England, it is often said, produced an entire revolution in her agrienlture, and indeed, when we consider how important a part it plays in our own system of farming, we ean witl difficulty imagine how our ancestors ever got on at all in farming without it. Be this as it may, it is certain that it led to many of the most important improvements in the rotation of erops. Clover is very properly regarded as a fertilizer of the soil. 'The action of its long' and powerful tap roots is not only mechanical,-loosening the soil and admitting the air,- -but also chemieal, serving to fix the gases important to enrich the earth, and when these roots decay they add largely to that black mass of matter we eall the soil. It serves, also, by its luxuriant foliage, to destroy anmual weeds which would spring up on newly seeded land, especially after imperfect cultivation. But onc of the most raluable uses of it, and one too often overlooked, is to shade the surface and thereby increase its fertility. 


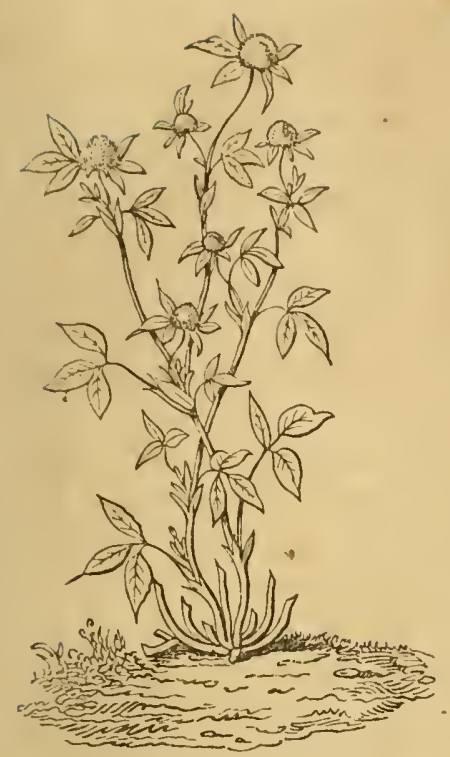

Fig. 86. Red Clover.

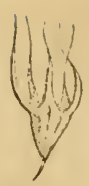

Fig. 88 .

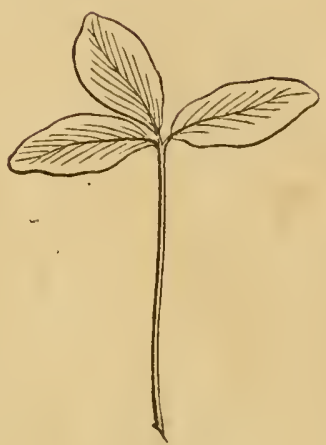

Fig. 8 .

Clover is emplatically a lime planit, and the soils best adapted to it are tenacious or stiff loams. The careful analysis of Prof. Way found no less than 35.39 per cent. of lime in the inorganic constituents of red clover, and that of Boussingault 32.80 per cent., while intelligent practice has arrived so nearly at the same conclusion, that the term "clover soils" is now almost universally used to iudicate a tenacious loam, containing more or less of lime in its composition.

Another great advantage in favor of the cultivation of clover, consists in its rapid growth. But a few months elapse from the sowing of the seed before it yields, ordinarily, an abundant and nutritious crop, relished by eattle of all kinds.

Clover seed should always be sown in the spring of the year, in the climate of New England. It is often sown upon the late snows of Marelı or $\Lambda$ pril and soon finds its way down to the soil, where, aided by the moisture of early spring it quickly germinates and rapidly shoots up its leaf stalks.

An accurate and raluable analysis of this plant, both in its green and dry state, will be found in a tabular form on a subsequent page, while a more extended notice, of its culture and 
the mode of curing it, with the results of practical experience as to its value, will also be given in their proper place.

White Clover, Dutch Clover, Honeysuckle, (trifolium repens, ) is equally common with the red, and often forms a very considerable portion of the sward or turf of pastures and fields of a tenacious and moist soil. Specific description : Stems spreading, slender and crecping, leares inversely licart-shaped, flower heads small, white, pods four sceded, root perennial. Flowers from May to September. Fig. 89. A magnified flower is seen Fig. 90.

White clover is widely diffused over this country and all the countries of Europe. It is indigenons probably both to England and America. When first cultivated from seed collected from wild plants, at the beginning of the last century, it was recorded of a farmer that he had "sowed the wild white clorer which loolds the ground and decays not." Its chief value is as a pasture grass, and it is as raluable for that purpose as the red clorer is for hay or for soiling, though there are some who place a low estimate upon it. It casily accommodates itself to a great varicty of soils, but grows most luxuriantly in moist grounds and moist or wet seasons. Indeed, it depends so much upon a general distribution of rains through the season, that when they are sufficiently abundant it comes in profusely even where it was not observed in other years, and hence such seasons pass under the term of "clover ycars." It is not apparently so much relished by stock as from its sweetness we should be led to expect, but it is, on the whole, to be cherished for permanent pastures, and improved, as it undoubtedly may be, by a proper selection and culture of varicties. For an accurate analysis of this plant the reader is referred to a subsequent page.

Lucerne, Alfalfa, (medicago sativa, Fig. 91.) This genus of leguminous plants has been known and cultirated from time immemorial. This particular species, lucerne, was brought from Media to Greece in the time of Darius, about fire hundred years before Christ, and its cultivation afterwards extended among the Romans, and through them to the south of France, where it has erer sinee continned to be a farorite forage plant. It does not endure a climate as severe as red clover, requiring greater heat and sunlight; but in a latitude equally suited to 
both plants it would be somewhat difficult to say which should have the preferenee. In some respects it is decidedly superior, as in being peremial, and eonsequently remaining long in the soil. I have seen fine speeimens of it in South Boston, where the sced was sown in 1824, still maintaining its rigorous loold

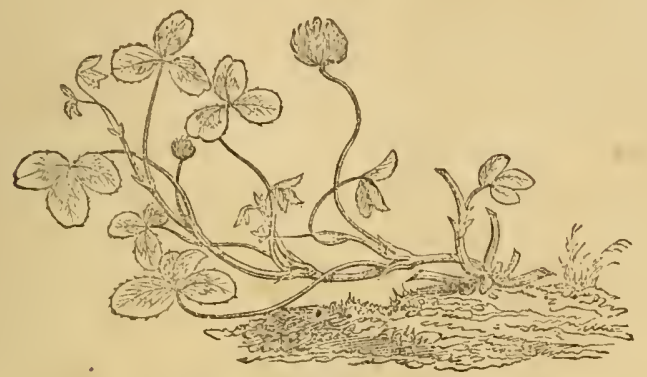

Fig. 89. White Clover.

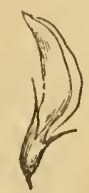

Fig. 90.

of the soil and growing with remarkable lusuriance. The crop of luecrne is as abundant as red elover, and is equally well relished by eattle, both green and dry. Its yicld of green fodder continues later in the season than that of red elover.

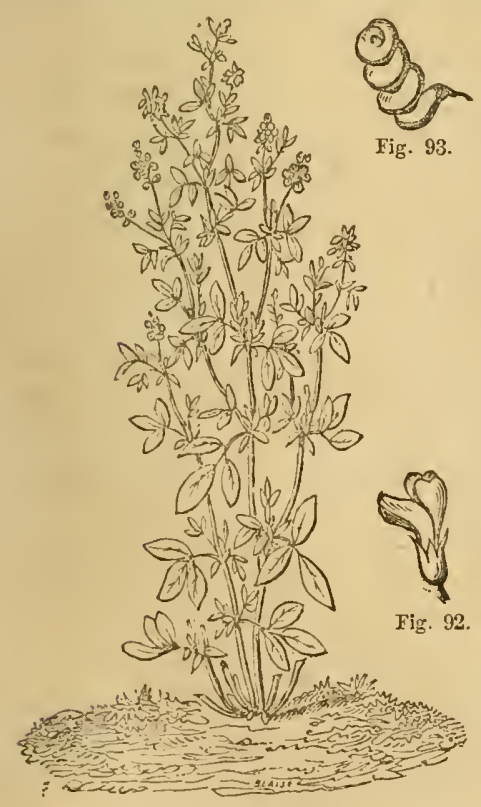

Fig. 91. Lucerne.

Lucerne sends down its tap roots in mellow soils, to enormous depths, liaving been found in sandy soils thirteen feet in length. The leaflets are in threes, oborate, oblong, toothed, the flowers pale blue, violet, or purple, shaped as in Fig. 92, the fruit in downy pods, having two or three twirls, as in Fig. 93.

Lueerne is cultirated in Chili and grows wild in the utmost luxuriance in the pampas of Buenos Ayres, where it is called alfalfa, which is simply the common lucerne, slightly modified by climate, and may be regarded as a varicty.

The cultivation of lncerne is somewhat more difficult than 
that of clorer for the first year, requiring a soil thoroughly mellowed and prepared by clean and careful tillage; and the want of proper attention to this point has led to partial failures in the attempts to raise it in this country. It suffers and languishes in compact clay soils, and does not flourish in light soils lying over an impermeable subsoil, which prevents the water from running off. It will never succeed well on thin soils. But in a permeable subsoil, consisting of loam, or sand or grarel, its roots ean penetrate to great depths, and being nearly destitute of lateral shoots, prorided with numerous fibrous rootlets, or radical off-shoots, imbibe their moisture and nutriment in layers of soil far below the average of other plants. In this respect it difeers materially from clover. For lucerne, a suitable subsoil is of the utmost consequence. For the short lived red clover, a suitable surface soil is more important; a want of care and deep tillage, especially a neglect to break through and loosen up the hard-pan whererer it exists, will ineritably lead to failure with lucerne. But when the soil is suitable, it will produce good and very profitable crops for from fire to ten or twelve years, and, of course, it does not belong in the system of short rotations.

But notwithstanding the large quantity of succulent and nutritious forage it produces, its effect is to ameliorate and improve the soil rather than to exhaust it. This apparent anomaly is explained by the fact that all leguminous, broad leared plants derive a large proportion of their nutritive materials from the atmosphere, and that a vast quantity of roots are left to decay in the soil when it is at last broken up, varying, of course, with the length of time the plant continues in the soil, while the luxuriant foliage serves to shade the soil and thus to increase its fertility. Much of this rich foliage is scattered and left to decay, as is the case with all similar plants at the time of harvesting, and the growth of the aftermath is also usually very considerable. The fact that it actually increases the fertility of the soil for other plants, has often been proved and may be regarded as fully established. A soil which would bear only a medium crop of wheat at first, produced a greatly increased quantity after being laid down to lucerne a few years till its roots had enriched the soil.

Lucerne should not follow immediately after haring been. 
grown a few years on the same soil, and then broken up, but after the land on which it has been grown has been eultirated with some other crop or laid down to the natural grasses a length of time equal to that during which it had previously remained in lucerne, it can safely be sown again with it.

The seed of lucerne, when fresh and good, is yellow, glossy and heary. If the seeds are white, it is an indication that they are not ripe. If they are brown, we may infer that they have been subjected to too strong a heat to separate them from their luusks. In either of these cases, it is not safe to purchase or to rely upon them. The same may be said of clover, and it is desirable to try them by a simple method which will be indicated hereafter in speaking of the selection of seed. As the seeds of lucerne are somewhat larger than elover seed and the plant tillers less, it is necessary to sow a larger quantity per acre. It may be sown in the spring along with grain crops, as clover often is, and not a very large crop should be expected the first year.

Lucerne should be cut as soon as it begins to flower, or even earlier. If cut much earlier it is apt to be too watery and less nutritious and cures with greater difficulty; if later, it becomes coarse and hard with woody fibre, and is less relished by cattle. It may be cut and fed green and is an exceedingly valuable plant for soiling cattle, or it may be cut and eured and used like clover hay; but in either case, it must be eut before blossoming.

It is thought by many, that lucerne will not endure the climate of New England, but I do not think it satisfactorily proved, and I have been somewhat minute in speaking of it, in the hope of inducing more careful experiments on a scale and under circumstances sufficient to determine its relative value for us. I am the more anxious on this point from the fact that I am convinced, after much study and observation of our climate, that we should direct our labors in farming more with reference to the frequent droughts of summer to which we are liable every year, and from which there is no immediate and practicable escape except in thorough drainage and deep tillage, which most farmers are unwilling to undertake at present. "When properly managed, the number of cattle which can be kept in good condition on an acre of lucerne, during 
the whole season, exeeeds belief. It is no sooner mown than it pushes out fresh shoots; and wonderful as the growth of clover sometimes is, in a field that has been lately mown, that of lncerne is far more rápid. Lucerne will last for many years, shooting its roots-tough and fibrous almost as those of liquorice -downwards for nourishment, till they are altogether out of the reach of drought. In the dryest and most sultry weather, when every blade of grass droops for want of moisture, lucerne holds up its stem, fresh and green, as in the genial spring."

I am.convinced, also, that the failures of attempts to cultivate lucerne with us may be ascribed, in nearly erery instance, to an improper selection of soils, and am inclined to think that a more accurate knowledge of the plant and a more careful observation of its habits of growth would lead to its more general adoption as an economical forage plant.

I have procured fine specimens of lucerne in various parts of this State, where it is very successfully cultivated, but on too limited a scale to determine its comparative value as a farm crop.

SaInforn, (hedysarum onobrychis,) differs from lucerne in many important particulars. It is a leguminous plant with many stems from two to three feet long, straggling, tapering, smooth, leares in pairs of pointed, oblong leaflets, slightly hairy on the under side, flower stalks higher than the leaves, ending in a spike of crimson or variegated flowers, succeeded by flat, liard pods, toothed on the edges and prickly on the sides, root perennial, and hard and woody. Flowers in July. Fig. 94. 'The flower is shown in Fig. 95, and the fruit in Fig. 96.

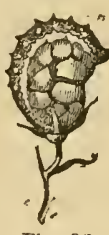

Fig. 96.

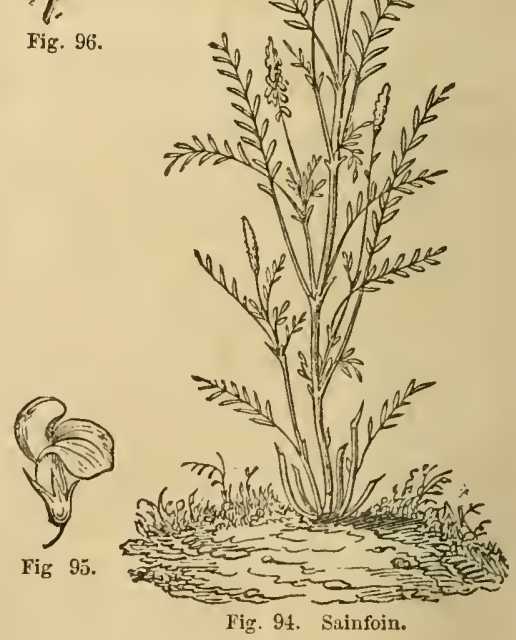

Experiments have been made in introdueing and eultivating it in this State, but without success. It requires a calcarcous soil. 
In the south of France, where it flourishes best, it is considered an indispensable forage plant, improving the quality and increasing the quantity of milk when fed to milch cows, to which it may be given without producing the "hoove," to which they are suljected when allowed to feed freely on green clover and lucerne. Its stalks do not become ligneous if allowed to stand till blossoming, as those of lucerue do. The amount of fodder obtained from it is less than that from clover or lucerne, but its quality, where it can be suecessfully grown, is better. Its fruit or seed is said to be far more nutritious than oats. They are eagerly sought by fowls, and cause them to lay.

Sainfoin, when green and young, will not endure a serere winter, but after the second or third year will endure a considerable degree of cold. It will suceed in very dry soils, sands and grarels. It is grown with great success in some of the southeru counties of England. Its seeds have been gencrally distributed orer the country through the agency of the Patent Office, but, so far as I know, they have been followed by no marked success in the way of crops in New England.

The arrow grasses form a limited family consisting of only three species found in Now England. They are arranged in the following table:-

Table II. List of Arrow Grasses. (Juncaginece.)

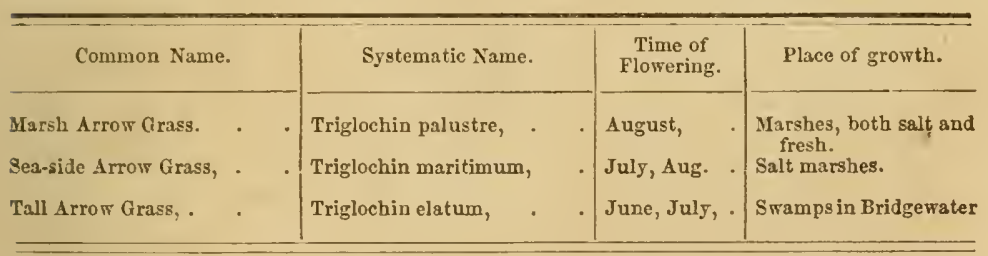

The second of these, the sea arrow grass, is common in our salt marshes, having rush-like leares of a sweetish taste, relished by eattle, and forming a rery good fodder when well cured.

Many of the rushes or grass-like plants so common along the borders of our ponds, and called grasses in popular language, are readily eaten in the spring while green and full of juice. They are arranged in the following table:- 
TABle III. List of Grass-like Rushes. (Juncacea.)

\begin{tabular}{|c|c|c|c|c|c|c|}
\hline Common Name. & & Systematic Name. & & & $\begin{array}{l}\text { Time of } \\
\text { Flowering. }\end{array}$ & Place of growth. \\
\hline Common Tood Rush, & & Luzula campestris, & - & . & April, Jay, & Fields and dry woods. \\
\hline $\begin{array}{c}\text { Broad-leared IIairy } \\
\text { Rush, }\end{array}$ & Wood & Luzula pilosa, & . & . & Nay, . & Open woods, river banks \\
\hline Small-flowered Wood R & iush, . & Luzula parviflora, & . & - & July, . & Mouutains, West. Mass. \\
\hline Soft Rush, . & . & Juncus effusus, . & . & . & June, . & $\begin{array}{l}\text { Swampy grounds : com- } \\
\text { mov. }\end{array}$ \\
\hline Slender Rush, & - & Juncus filiformis, & - & - & July, & . Wet banks and shores. \\
\hline Baltic Rush, . & . & Juncus-baltieus, . & - & - & July, & Sandy shores: \\
\hline Smaller Round-headcd & Rush, & Juncus nodosus, . & . & . & July, & $\begin{array}{l}\text { Borters of rivers and } \\
\text { ponds. }\end{array}$ \\
\hline Many-headed Rush, & . & Juncus polycephalus, & . & - & July, & Wet places. \\
\hline Sharp-fruited Rusli, & - & Juncus acuminatus, & - & . & August, & Boggy swamps. \\
\hline Brownish-fruited Rush & , & Juncus articulatus, & - & - & - & Tet places. \\
\hline Conrad's Rush, & . & Juncus Conradi, . & . & - & July, Aug. & $\begin{array}{l}\text { Borders of ponds in } \\
\text { sandy soil. }\end{array}$ \\
\hline Toad Rush, . & . & Juncus bufonius, & . & . & June, Aug. & Low grounds, roadsides \\
\hline Slender Rush, & - & Juncus tenuis, . & - & - & June, Aug. & Low grounds, fields. \\
\hline Greere's Rush, & . & Juncus Greenei, . & - & - & July, . & $\begin{array}{l}\text { Sandy borders of salt } \\
\text { marshes. }\end{array}$ \\
\hline Black Grass, . & - & Juncus bulbosus, & . & - & August, & Borders of salt marshes \\
\hline Grass-leared Rush, & - & Juncus marginatus, & - & - & July, & Moist, sandy swamps. \\
\hline Long-fruited liush, & . & Juncus Stygius, & - & - & - & Peat swanips, \\
\hline Three-leared Rush, & . & Juacus trifidus, & . & . & July, & Mountain summits. \\
\hline
\end{tabular}

The most prominent and raluable of these plants is the

Black Grass, (juncus bulbosus, var. gerardi, ) an inhabitant of salt marshes. This plant has a simple, slender stem, somewhat flattened, from one to two feet high. It is considered the best product of the salt marshes and grows most luxuriantly along their borders which are only occasionally orerflowed by the tides, often working its way to the uplands where the seed is scattered, in large quantities, in curing. It should be cut early, and when well cured is thought to be nearly equal in value to good English hay. "Though not of itself equal in ralue, weight for weight, to "goose grass," (poa maritima, p. 17, Fig. 30, yet the product per acre is so much larger as to make it a more desirable crop.

Most of the salt marsh plants have already been described in the natural history of the true grasses.

The "Goose Grass," one of the most valuable of them, was mentioned under its synonym, Sea Spear Grass, Fig. 30, p. 48 , 
the name "goose grass," by which it is more generally known along the shores of Essex county and Cape Cod, having been inadrertently omitted. It is generally considered one of the best products of the salt marsh when it grows in mixture with other species of plants, as the black grass, for instance, and deserves a more extended notice.

It is rery well known that large tracts of salt marsh are nearly barren. Sometimes close cutting in the early morning, while the dew is on the grass and when it cuts comparatively easy, kills it out, and from that cause the marsh becomes barren. More often, howerer, excess of water, either upon the surface or in the soil, from the proximity of ponds which hare no outlet, causes barrenness. On all such tracts goose grass springs up and dots the whole surface with eireular patches of green, which in shape are rery like ringworms on the human skin. This grass is seldom found alone except on these barren tracts, and upon them it grows so short and thin as seldom to be worth cutting. One will therefore nerer see any goose grass hay except mired with other kinds, and generally with black grass. When these tracts begin to improve, either from draining or from any other cause, other grasses make their appearance, and the goose grass grows much more rigorous and becomes valuable. This will continue to be the case for sereral years, until the roots of the other grasses hare taken entire possession of the soil, when the goose grass disappears almost entirely and bides its time, ready to appear again whenerer from any cause its intrusire competitors cease to exist.

The hay made from the mixture of goose and other grasses -among which black grass generally predominates-is a most raluable fodder. The goose grass is so weighty that it takes but a small quantity, comparatively, for a ton, and cattle eat it with almost as much aridity as oats or any other grain. In fact, no hay is more raluable than black grass with a large admixture of goose grass, when properly cured.

The curing process requires care and time, for goose grass is as full of sap as possible, and requires a much longer exposure than black grass, while a rery little wet when it is partially curcd, materially injures the black grass.

We may judge of the properties of goose grass from the 
fact, that in several instances within my own knowledge, cattle have died of loove from eating it early in the spring.

It resembles in the shape of its leaves, and somewhat in its cluster-like growth, that species of garlic which used formerly to be grown in kitchen gardens called cives, or more properly chives. Its seed stalks and seeds are almost precisely like the seed stalks and seeds of the common plantain.

It grows both on high and low marshes, but is very seldom worth cutting on those tracts where it grows by itself and without the admixture of other grasses.

It is proper to state in this connection that experiments have been made to introduce this raluable grass into our fresh wet meadows, and with good success.

Most of the superior salt marsh grasses are greatly improved by ditching, while the poorer and comparatively worthless plants found there very soon die out after this operation and give place to more valuable species. It may be safely asserted that, on an average, the value of the marsh is nearly doubled by it, while the regetable, peaty matter taken from it is sufficient, if properly used, to pay a considerable portion of the outlay.

There is also a small family of plants called the yellow eyed grasses, or the star grasses, consisting of only two species, the first of which is the Yellow Eyed Grass, (xyris bulbosa,) flowering in July, August and September, growing on sandy and peaty soils, and bogs near the coast; and the second, the Common Yellow Eyed Grass, (xyris caroliniana,) flowering in August, on sandy swamps. These are beautiful grasses, of no special agricultural value.

There is still another great family of plants which, though of no agricultural value. in point of nutritive properties as compared with the true grasses, is, nevertheless, extensively used in New England for forage purposes, and consequently deserves a passing mention. I refer to the sedges, and plants constituting the coarse and innutritious herbage properly included in the term, CAREX, a large and prominent genus of grass-like plants, consisting in all of about four hundred and fifty species known to botanists, extensively diffused over all the damp parts of the globe, and in popular language called grasses. A few species 
of earex grow on sandy hills and along the sea shore, but most inhabit marshes, wet meadows, swamps, and the low, wet banks of streams and ditches, and moist woods. Somewhat over a liundred species are found in New England. None of them are of any real agricultural ralue, though they constitute mainly what we term " meadow hay," or more properly swale hay, in eastern Massachusetts. They are nearly destitute of mealy and saccharine principles in which many of the true grasses abound, and are eaten by eattle only when compelled by liunger, in the want of better grasses. It not unfrequently happens, howerer, that there is an admixture of the higher grasses among the carices or sedges, such as the fowl meadow, the bastard fowl meadow, the white top or some of the other species possessing higher nutritive qualities, and then, of course, the hay made from the swale is proportionably improred, and may thus become of considerable value for winter fodder.

The Sedges are arranged in the following table:-

\section{Table IV. List of Carices or Sedges, (Cyperacea.)}

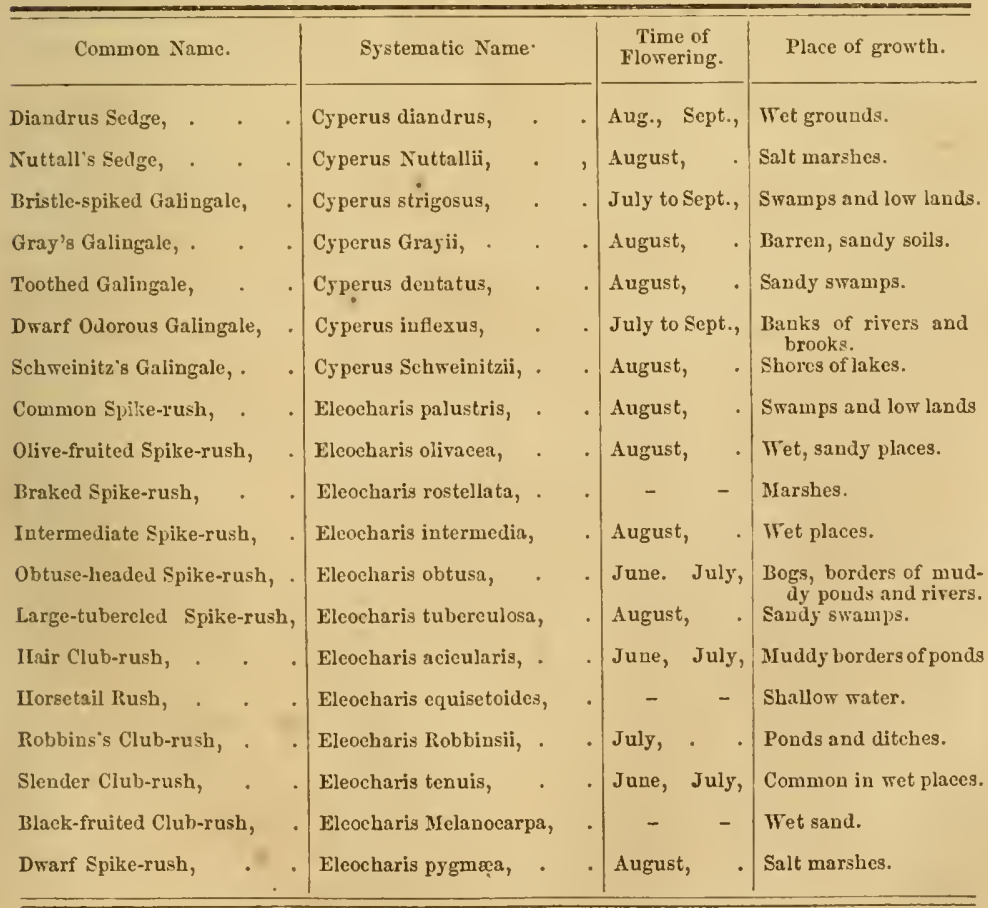


TABLE IV.-Continued.

\begin{tabular}{|c|c|c|c|c|c|c|}
\hline \multicolumn{3}{|l|}{ Common Name. } & \multicolumn{2}{|l|}{ Systematic Name. } & $\begin{array}{l}\text { Time of } \\
\text { Flowering. }\end{array}$ & Place of growth. \\
\hline Scaly-stalked Club-rush & & & Scirpus cæspitosus, & . & July, . & Wet mountains. \\
\hline Flat-leaved Club-rush, & & & Scirpus planifolius, & . & June, & Woods, and in bogs. \\
\hline Floating Club-rush, & - & & Scirpus subterminalis, & - & August, . & Sluggish streams: rare. \\
\hline $\begin{array}{l}\text { Chair-bottom Rush, } \\
\text { Olney's Rush, . }\end{array}$ & . & . & $\begin{array}{l}\text { Scirpus pungens, } \\
\text { Scirpus Olneyi, }\end{array}$ & $\cdot$ & $\begin{array}{l}\text { July, Aug. } \\
\text { July, . . }\end{array}$ & $\begin{array}{l}\text { Borders of salt marshes } \\
\text { and fresh ponds. } \\
\text { Salt marshes. }\end{array}$ \\
\hline Torrey's Rush, & . & . & Scirpus Torreyi, . & . & July, Aug. & Borders of ponds. \\
\hline Bulrush, . & . & . & Scirpus lacustris, . & $\cdot$ & July: : & $\begin{array}{l}\text { Borders of muddy rivers } \\
\text { and ponds. }\end{array}$ \\
\hline Weak-stemmed Rush, & - & & Scirpus debilis, . & . & August, & $\begin{array}{l}\text { Borders of sandly rivers } \\
\text { and lakes. }\end{array}$ \\
\hline Sca Bulrush, & . & - & Scirpus maritimus, & & August, . & $\begin{array}{l}\text { Salt marshes and salt } \\
\text { springs. }\end{array}$ \\
\hline Ríver Rush, . & . & $\cdot$ & Scirpus fluviatilis, & - & July, Aug. & $\begin{array}{l}\text { Borders of lakes and } \\
\text { large streams. }\end{array}$ \\
\hline Wood Rush, . & $\cdot$ & & Scirpus sylvaticus, & . & July, . & Wet $\mathrm{m}$ \\
\hline Cluster-head Rush, & . & . & Scirpus polyphyllus, & . & July, & $\begin{array}{l}\text { Swamps, shady bo } \\
\text { of ponds. }\end{array}$ \\
\hline Porter's Rush, & - & - & Scirpus lineatus, . & . & July, . & stern Mass. \\
\hline Wool Grass, . & . & . & Seirpus Eriophorum, & . & July to Sépt. & Wet meadows, swamps. \\
\hline Cotton Grass, & . & . & Eriophorum Alpinum, & & May, June, & Peat swamps. \\
\hline IIarestail, . & - & . & Eriophorum vaginatun & & June, . & $\begin{array}{l}\text { Mossy swamps and } 1 \\
\text { mountains. }\end{array}$ \\
\hline Rusty Cottou Grass, & · & & Eriophorum Virginicux & & July, Aug. & Common in swamps. \\
\hline Broad-leared Cotton Gr & Irass, & & Eriophorum polystach & yon, . & June, July, & Boggy meadows. \\
\hline Narrow-leaved Cotton & Grass & & Eriophorum gracile, & . & June to Aug. & Wet mossy 8wamps. \\
\hline Tall Fimbristylis, . & . & & Fimbristylis spadicea, & & July to Sept. & Salt marshes : rare. \\
\hline Tufted Fimbristylis, & . & & Fimbristylis autumalis & & Aug. to Oct. & Low grounds. \\
\hline Hair-hike Fimbristylis, & . & . & Fimbristylis capillaris, & & Aug., Sept. & $\begin{array}{l}\text { Common on sandy } \\
\text { fields. }\end{array}$ \\
\hline Umbrella Grass, . & . & - & Fuirena squarrosa, & . & August, & Sandy, wet places. \\
\hline Bald Rush, . & - & - & Psilocarya seirpoisles, & & July, & Inundated swamps. \\
\hline Horned Rush, & - & . & Ceratoschcenus macrost & stachya & - & Borders of ponds : rare. \\
\hline Dwarf IIemiearpha, & - & & IIemicarpha subsquarr & rrosa, . & July, . & $\begin{array}{l}\text { Sandy borders of rivers } \\
\text { and lakes. }\end{array}$ \\
\hline White Beak-rush, . & - & & Rhyuchospora alba, & - & July, Aug. & $\begin{array}{l}\text { Mossy swamps, com- } \\
\text { mon. }\end{array}$ \\
\hline Small Beak-rush, . & - & & Ihynchospora capillace & cea & July, . & Swamps and marshes. \\
\hline Brown Beak-r'ush, & . & & Rhynchospora fusca, & & July, . & Low wet grounds: rare. \\
\hline Tall, Slender Beak-rush & & & Rhynehospora gracilen & & - & Low grounds. \\
\hline Common Beak-rush, & $\cdot$ & & Rhynchospora glomera & ata, & July, Aug. & Boggy grounds. \\
\hline Round-head Beak-rush, & & & Rhynchospora cephala & lantha, & August, & Sandy swamps. \\
\hline Smooth Twig-rush, & & & Cladium mariscoides, & & July, . & $\begin{array}{l}\text { Borders of ponds, bog } \\
\text { meadows. }\end{array}$ \\
\hline Sessile-spiked Nut-rush & & & Scleria reticularis, & - & August, & $\begin{array}{l}\text { Sandy swamps aud bor- } \\
\text { ders of pouds. }\end{array}$ \\
\hline Loose-flowered Nut-rus & & & Scleria laxa, & . & August, & Sandy swamps. \\
\hline $\begin{array}{l}\text { arce-clustcred Nut-r } \\
\text { Whip-grass, }\end{array}$ & ush, & & Scleria triglomerata, & - & July, . & $\begin{array}{l}\text { Swamps and moist } \\
\text { thiekets. }\end{array}$ \\
\hline Few-flowered Nut-rush & & - & Scleria pauciflora, & - & July, & Swamps and hills. \\
\hline
\end{tabular}


TabLe IV.-Contimued.

\begin{tabular}{|c|c|c|c|c|c|c|c|c|c|c|}
\hline \multicolumn{3}{|l|}{ Common Name. } & \multicolumn{4}{|c|}{ Systematic Name. } & \multicolumn{3}{|c|}{$\begin{array}{l}\text { Time of } \\
\text { Flowering. }\end{array}$} & Place of growth. \\
\hline Dwarf Verticillate Sut- & t-rus & & Seleria verticillat & & - & . & June, & $\cdot$ & & Swarups. \\
\hline Slender Selige, . & - & - & Carex exilis, & - & . & . & June, J & July, & , & Marshes iu Dauvers. \\
\hline Few-flowered Sedge, & - & . & Carex paucitlora, & & - & . & - & & - & Peat swamps. \\
\hline Bristle-stalked Sedge, & - & . & Carex polytrichoi & Dides, & $\cdot$ & $\cdot$ & May, & - & $\cdot$ & Low grounds \& woods. \\
\hline Willdenow"s Sedge, & . & - & Carex Willdenovi & & - & $\cdot$ & May, & - & $\cdot$ & Moist, shady places. \\
\hline Back's Sedge, & - & - & Carex Backii, & . & - & $\cdot$ & - & & - & $\begin{array}{l}\text { Mount Tom and rocky } \\
\text { hills. }\end{array}$ \\
\hline Two-seeded Sedge, & . & . & Carex disperma, & . & . & . & June, & . & & $\begin{array}{l}\text { Mossy swamps and } \\
\text { mountuins. }\end{array}$ \\
\hline Long-rooted Sedge, & - & - & Carex eherelorhig & iga & $\cdot$ & . & May, & $\cdot$ & - & Mossy swamps. \\
\hline Oval-headed Sedge, & - & - & Carex cephalophe & 1ora, & - & - & May, & - & - & Hill-sides and fields \\
\hline Muhlenberg's Sedge, & - & - & Carex Muhlenber & rgii, & - & . & April, & - & - & $\begin{array}{l}\text { Rocky hill-sides and } \\
\text { mountains. }\end{array}$ \\
\hline Drj-spiked Sedge, . & - & $\cdot$ & Carex siccata, & . & - & • & - & & - & Sandy plaius. \\
\hline Ilose Sedge, . & - & - & Carex rosea, & . & - & - & May, & - & - & $\begin{array}{l}\text { Moist woods and low } \\
\text { grounds. }\end{array}$ \\
\hline Retroflexed Sedge, & - & . & Carex retroflexa, & & - & . & May, & - & . & $\begin{array}{l}\text { Open woods and moist } \\
\text { nueadows. }\end{array}$ \\
\hline Bur-reed Sedge, . & - & $\cdot$ & Carex sparganioic & ides, & - & - & May, & . & - & Low swampy grounds. \\
\hline Awl-fruited Sedge, & * & - & Carex stipata, & $\cdot$ & - & . & April, & . & . & Swamps, low grounds. \\
\hline Fox Sedge, . & . & - & Carex vulpinoide & & . & - & May, & - & - & Low grounds: common \\
\hline Bristly-spiked Sedge, & - & - & Carex setacea, & - & - & . & June, & - & - & Wet meadows. \\
\hline Bromus-like Seuge, & - & . & Carex bromoides, & & - & $\cdot$ & May, & - & - & Wet swamps. \\
\hline Foxtail Sedge, & - & . & Carex alopeeoidea & & - & . & - & & - & Woods. \\
\hline Sartwell's Sedge, . & - & $\cdot$ & Carex Sartwellii, & & . & - & - & & - & - \\
\hline Lesser-panicled Sedge, & . & - & Carex teretiuscul & & - & $\cdot$ & June, & - & $\cdot$ & Swamps : common. \\
\hline Large-panicled Sedge, & - & . & Carex decomposit & ta & - & - & - & - & - & Swamps. \\
\hline Three-seeded Sedge, & . & - & Carex trisperma, & & $\cdot$ & . & June, & - & - & $\begin{array}{l}\text { Peat swamps, wet } \\
\text { mountain woods. }\end{array}$ \\
\hline Dewey's Sedge, & - & - & Carex Dewreyana, & & . & - & June, & - & - & Moist woods. \\
\hline White Carex, & - & $\cdot$ & Carex canescens, & & - & - & Mas, & - & . & Wet meadows. \\
\hline Little Prickly Sedge, & . & - & Carex stellulata, & & * & . & May, & . & - & Wet neadows. \\
\hline Slender Cluster-spiked S & Sedg & & Carex tenuiflora, & & - & . & June, & - & - & Mossy swamps. \\
\hline Broom-like Sedge, . & . & . & Carex scoparia, & & - & $\cdot$ & - & 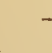 & 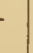 & $\begin{array}{l}\text { Wet meadows and } \\
\text { swamps. }\end{array}$ \\
\hline Stratv-colored Sedge, & . & - & Carex straminea, & & - & - & May, J & une, & - & $\begin{array}{l}\text { Borders of woods and } \\
\text { fields. }\end{array}$ \\
\hline Long-stalked Sedge, & . & - & Carex peduuculat & & . & - & April, & - & - & $\begin{array}{l}\text { Rocky hills and dry } \\
\text { woods. }\end{array}$ \\
\hline Square-headed Sedge, & - & . & Carex squarrosa, & & . & - & May, & - & . & Low meadows, thickets \\
\hline Buxbaum's Seuge, & - & - & Carex Buxbaumii & & $\cdot$ & - & May, & - & . & Mossy swamps. \\
\hline Three-herded pubescent & $\mathrm{tSed}$ & & Carex triceps, & & - & - & May, & . & - & Woods and meadows. \\
\hline Green-spiked pubescent & $\mathrm{tScd}$ & & Carex virescens, & $\cdot$ & . & $\cdot$ & May, & - & . & Toods aud hill-sides. \\
\hline Slender Sorlding Sedge, & & . & Carex gracillima, & & . & . & June, & - & . & Moist grounds. \\
\hline Showy Seuge, & - & . & Carex formosa, & . & . & . & May, & - & - & Wet meadows. \\
\hline Davis's Sedge, & . & - & Carex Darisii, & . & . & . & May, & - & - & Swamps, river banks. \\
\hline Rigid Sedge, . & . &. & Carex rigida, & . & . & $\dot{-}$ & July, & - &. & Mountain summits. \\
\hline
\end{tabular}


Tabre IV.-Continued.

\begin{tabular}{|c|c|c|c|c|c|c|c|c|c|c|}
\hline \multicolumn{3}{|l|}{ Common Name. } & \multicolumn{4}{|c|}{ Systematie Name. } & \multicolumn{3}{|c|}{$\begin{array}{l}\text { Time of } \\
\text { Flowering. }\end{array}$} & \multirow{2}{*}{$\frac{\text { Place of groirth. }}{\text { Swamps : common. }}$} \\
\hline Large Bog Sedge, . & . & - & Carex augustata, . & & - & - & May, & $\cdot$ & - & \\
\hline Smaller Bog Sedge, & . & - & Carex easpitosa, . & & - & - & May, & & - & $\begin{array}{l}\text { Swamps and banks of } \\
\text { streams. }\end{array}$ \\
\hline Water Sedge, & - & $\cdot$ & Carex aquatilis, . & - & * & - & June, J & July, & $\cdot$ & $\begin{array}{l}\text { Borders of lakes and } \\
\text { rivers. }\end{array}$ \\
\hline Golden-fruited Sedge, & . & - & Carex aurea, & - & • & - & May, J & une, & - & $\begin{array}{l}\text { Borders of swamps and } \\
\text { brooks. }\end{array}$ \\
\hline Fringed Sedge, . & . & - & Carex erinita, & - & • & - & May, J & une, & $\cdot$ & Swamps, river banks. \\
\hline Few-fruited Sedge, & - & . & Carex oligosperma & $a$, & . & - & June, & & - & $\begin{array}{l}\text { Mountains, borders of } \\
\text { swamps. }\end{array}$ \\
\hline Iuflated Sedge, & - & - & Carex bullata, & - & - & - & May, & - & . & Swamps: not eommon. \\
\hline Cyliudrical-spiked Sedg & & & Carex eylindriea, . & & . & - & - & - & & Swamps : common. \\
\hline Bladder-fruited Scdge, & - & - & Carex utrieulata, & & - & - & May, & - & - & Wet swamps. \\
\hline Awl-fruited Sedge, & - & - & Carex subulata, & • & - & - & May, & - & . & Cedar swamps. \\
\hline Tall Yellow Scdge, & - & - & Carex follieulata, & - & - & - & June, & - & - & Swantps, peat bogs. \\
\hline Swollen-fruited Sedge, & . & - & Carex intunescen & as, & - & - & June, & - & - & $\begin{array}{l}\text { Wet grounds and open } \\
\text { weods. }\end{array}$ \\
\hline Hop Sedge, . & - & - & Carex lupulina, & - & - & . & June, & - & - & $\begin{array}{l}\text { Swamps and borders of } \\
\text { ponds. }\end{array}$ \\
\hline Rough-fruited Sedge, & - & - & Carex scabrata, & $\cdot$ & - & - & May, & - & . & Borders of brooks. \\
\hline Schweitnitz's Sedge, & . & - & Carex Schweinitzii & & - & . & May, & - & - & Swamps. \\
\hline Late-fruited Sedge, & - & - & Carex retrorsa, & - & $\cdot$ & - & May, & . & - & $\begin{array}{l}\text { Borders of ponds and } \\
\text { streams. }\end{array}$ \\
\hline Long-pointed Sedge, & . & - & Carex teutaculata & & $\cdot$ & - & May, & - & - & Swamps. \\
\hline Poreupine Scdge, . & - & - & Carex hystricina, & & - & - & June, & - & - & Swamps: common. \\
\hline Csperus-like Sedge, & - & - & Carex Pseudo-Cyp & perus, & & - & June, & - & - & $\begin{array}{l}\text { Swamps and sluggish } \\
\text { streamz. }\end{array}$ \\
\hline Long-beaked Sedge, & - & - & Carex longirostris & & - & - & June, & - & - & Shady, rocky places. \\
\hline Ifairy-fruited Sedge, & . & - & Carex trichoearpa & & - & - & June, & - & . & Marshes and lakes. \\
\hline Awned Sedge, & . & - & Carex aristata, & - & $\cdot$ & . & - & - & & Lake shores. \\
\hline Cmbel-spiked Serge, & - & - & Carex unbellata, & & - & - & May, & $\cdot$ & - & Rocky bill-sides. \\
\hline Pennsylvanian Sedge, & - & - & Carex Penneylvan & aica, . & - & - & April, & . & . & Dry woods and hill-sides \\
\hline New England Sedge, & . & - & Carex Noræ-Angli & ix, & - & . & June, & - & - & $\begin{array}{l}\text { Woody hills and moun- } \\
\text { tains. }\end{array}$ \\
\hline Slender-leaved Serlge, & - & . & Carex filiformis, & - & . & - & May, & - & . & Peat swamps. \\
\hline Woolly-fruited Sedge, & . & . & Carex lanuginosa, & & . & . & May, & . & - & $\begin{array}{l}\text { Swamps and borders of } \\
\text { ponds. }\end{array}$ \\
\hline Short Woolly-spiked Se & edge, & . & Carex restita, & - & - & - & May, & $\cdot$ & - & Moist, sandy soils. \\
\hline Pubescent Scage, . & . & . & Carex pubescens, & $\cdot$ & - & • & May, & - & - & Woods and swamps. \\
\hline Nud Sedge, . & . & - & Carex limosa, & . & . & . & June, & . & - & Mossy swamps. \\
\hline Livid Sedge, . & . & - & Carex livida, & - & . & - & June, & - & . & Mossy swamps. \\
\hline Large Yellow Carex, & - & . & Carex flava, . & . & . & . & May, & . & - & Swamps. \\
\hline (Eder's Sedge, & - & - & Carex Ederi, & - & . & . & May, & - & - & Wet limestone rocks. \\
\hline Pale Pubescent Sedge, & $\cdot$ & ${ }^{*}$ & Carex pallescens, & . & . & - & May, & . & - & Swamps. \\
\hline Torrey's Sedge, & - & - & Carex Torreyi, & - & . & - & - & - & & Nortlıward. \\
\hline Striated Sedge, & . & . & Carex striata, & - & - & . & May, & - & - & Swamps. \\
\hline Granular-spiked Sedge, & & - & Carex granularis, & & - & $\cdot$ & May, & - & * & Wetswamps: eommon. \\
\hline Inoose-flowered Sedge, & . & - & Carex laxiftora, & - & $\cdot$ & • & May, & . & $\cdot 1$ & Swamps \& moist wookls. \\
\hline
\end{tabular}


TABLE IV.-Continucd.

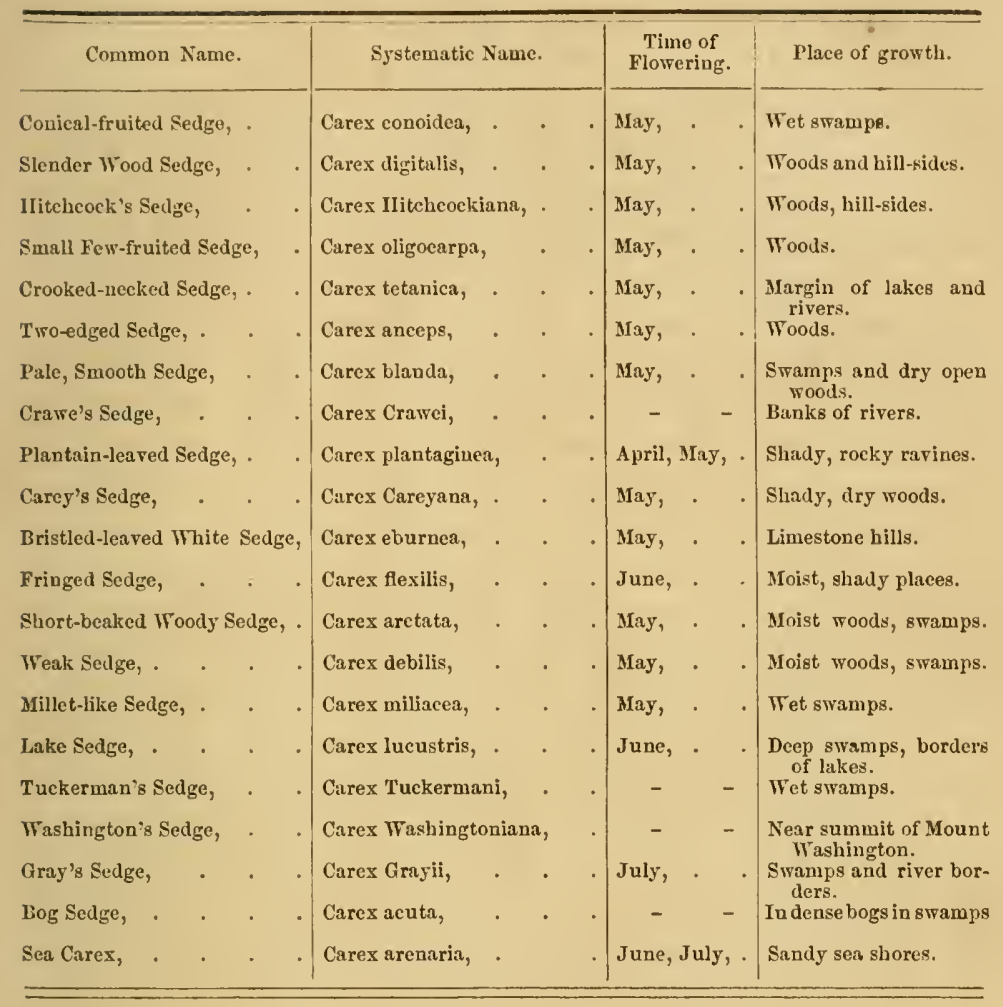

This table includes all the species of earex known and described as inhabitants of our low lands, and is thought to be very complete. As already intimated, none of these coarse sedges are rich in nutritive elements, and none are worthy of cultivation. 'The farmer's care should be to eradicate them and supply their places with the higher and more nutritious grasses. This may be done by thorough draining, an operation which lies at the foundation of all sucessful management of low lands, and without which they are comparatively worthless, while, if properly reclaimed, they are among the best and most productire lands on the farm.

The roots of the sedges are perennial, and for the most part creeping, a few being tufted and fibrous. The stems are simple and free from joints or nodes. The leaves are linear, flat, pointed, roughish on the surface and sharp on the edges. 
The grasses whose natural history has been stated in the preceding pages, might be separated into four or fire distinct groups, which would facilitate the study of them; for it must have been observed that many of them possess marked peculiarities of growth.

I. We find first the bush or jungle grasses, or such as are not inclined to grow with other species, and form a close, matted turf or sward. Of these we have as examples the

'Tufted Hair Grass, (aira caspitosa.)

Meadow Oat Grass, (avena pratensis.)

Tall Fescue Grass, (festuca elatior.)

A few others, if sown alone, will assume somewhat the same form, in tufts or cushions, as

Sheep's Fescue, (festuca ovina.)

Hard Fescue, (festuca duriuscula.)

Orchard Grass, (dactylis glomerata.)

This peculiarity in the growth of the last three grasses is prevented by close pasturing, rolling and proper cultivation. These operations improve upon nature, since if left to themselres they would far more certainly assume the jungle growth, such as is often seen on poor, thin pasture soils, especially in the south-eastern parts of the State, where on the sandy soils this mode of growth is every where observable-a close, fine, matted sward being attained only by careful cultivation.

II. The aquatic or water grasses form another distinct group, and among these are the

Reed Canary Grass, (phalaris arundinacea,)

Common Reed Grass, (arundo phragmites.)

Water Spear Grass, (poa aquatica.)

Common Manna Grass, (poa fluitans.)

Rice Grass, (Leersia oryzoides.)

Floating Foxtail, (alopecurus geniculatus.)

Wild Rice, (zizania aquatica.)

These grasses grow mostly in water and are not cultirated with us as agricultural grasses with the exception, perhaps, of 
the first. Wild rice grass is sometimes cultivated and yields large crops at the South, and floating foxtail in Europe.

III. Marsh or Salt Grasses, among which we have Salt Reed Grass, (spartina polystachya.)

Rush Salt Grass, (spartina juncea.)

Salt Marsh Grass, (spartina stricta.)

Black Grass, (juncus bulbosus.)

Beach Grass, (ammophila arundinacea.)

Goose Grass, (poa maritima.)

IV. Field or Pasture Grasses. Under this head may be included. a very large number of species, all of which have been described above. These grasses might be subdivided according to the soils and situations which they naturally affect; for though a grass may sometimes be found or placed in a soil which is not naturally fitted for it, yet no species will arrire at its most perfect development on a soil not well adapted to it.

Among these might be mentioned as examples

Timotliy, (phleum pratense.)

Meadow Foxtail, (alopecurus pratensis.)

Common Spear Grass, (poa pratensis.)

Orchard Grass, (dactylis glomerata.)

Peremnial Rye Grass, (lolium perenne.)

Italian Rye Grass, (lolium italicum.)

Redtop, (agrostis vulgaris.)

Whitetop, (agrostis alba.)

Downy Oat Grass, (avena pubescens.)

Meadow Soft Grass, (holcus lanatus.)

Meadow Fescue, (festuca pratensis.)

Field Barley Grass, (horleum pratense.)

Tall Oat Grass, (arrhenatherum avenaceum.)

V. Axweal Weeds, which, thongh proper grasses; are often rery troublesome in cultivated grounds, either on account of their creeping, underground stems, or their rapid and luxuriant growth. Thrifty farming is a ceaseless struggle against these pests, and the farmer is generally careful to keep as clear as possible of them. Among these may be named 
Willard's Bromus, (bromus secalinus.)

Soft Brome Grass, (bromus mollis.)

Slender Foxtail, (alopecurus agrestis.)

Creeping Bent Grass, (agrostis stolonifera.)

Couch, or Twitch Grass, (triticum repens.)

Rough Stalked Meadow Grass, (poa trivialis.)

Annual Neadow Grass, (poa annua.)

Blue, or Wire Grass, (poa compressa.)

Of these, the last four are not always considered as weeds, since they are sometimes sown as pasture grasses; but when they appear in cultivated grounds, in gravel walks and arenues, they are exceedingly troublesome and difficult to eradicate.

Each of the groups indicated abore may be considerably enlarged by a study of the natural history of the grasses presented in the foregoing pages.

Many of the grasses which have been described, possess but little ralue for the purposes of eultivation, it is true, but it should not be forgotten that they all hare their uses, and these uses in the grand economy of nature are exceedingly important, however they may appear to our short sighted vision. No plant comes up to the sunlight or expands its beautiful leares, that does not derive its support in part from the atmosphere, and even though its life be short, it adds materially in its decay to the rast mass of regetable mould which covers the surface of the globe and forms the richness of the soil. This surface mould has been accumulating for ages in many localities; every plant that grew in ages past bringing down to us in a tangible form the riches with which the air that surrounded it was stored, which now lie waiting the farmers' use in meadows of exhaustless fertility, in swamps and bogs of rast, increasing utility in our agriculture, and in beds of peat, the value of which we have scarcely begun to appreciate. Thus, the grasses which are not cultivated for their direct nutritive qualities, are not without their value, and they deserve our careful study and attention. 


\section{NUTRITIVE VALUE OF THE GRASSES.}

We have seen that the various species of grass differ very materially in nutritive value; that some contain the greatest quantity of nutritive matter when green or in the flower; others when the seed is ripe and the plant mature; that some yield a luxuriant aftermath, while others can scarcely be said to produce any at all; that some flourish in elevated situations and are best suited to the grazing of sheep, while others grow most luxuritutly on the low lands and in the marshes, and sustain the richest dairies; and that no soil is so sterile, no plain so barren but that a grass can be found adapted to it. Some varieties, indecd, will not endure a soil eren of medium fertility, nor the application of any stimnlating manure, but cling with astonishing tenacity to the drifting sands, while others prefer the lieariest clays or revel in the hot beds of ammonia; some are gregarivus in their habits, requiring to be sown with other species, and if sown alone will linger along till the wild grasses spring up to their support; other's are solitary, and if mixed with difierent species will either extirpate them, usurping to themselres the entire soil, or die and disappear. Nearly every species is distinguished for some peculiar quality, and most are deficiont in some, comparatively few combining all the qualities desired by us in alternate field crops, for pastures or permanent mowing, to sucl an extent as to justify a general cultivation.

It is important, therefore, to learn the comparative nutritive value of each species thought to be worth eultivating.

This study is naturally attended with great difficulties. It is but recently that accurate researches have becn made with a view of arriving at such positive results as would be entitled to full contidence.*

It is nuw very well established that the nutritive value of the food of an animal depends chiefly upon the proportion of nitrogenous substances contained in it. Without doubt, the sugar

* In 182t, a rery laudable attempt was made in England by the Duke of Bedford, at Woburn Abbey, to asecrtain the comparative value of most of the grasses which could then be obtained, and the results of the experiments, 
which is found to be an ingredient of most regetable substances at some periods of their growth, in some degree contributes to it also. The nitrogenous constituents of any substance, as grass or liay, for instance, may be determined with little difficulty and with great exactness, since it has been found by abundant research, that, when present, they are of nearly the same constitution, and do not vary in their combinations. The determination of the sugar is somewhat more difficult.

The constituents of plants may be divided into two classes, one class embracing all those substances of which nitrogen or azote forms a part, and the other consisting of non-nitrogenons bodies. Gluten, albumen, gelatine, casein, legumen and fibrin, belong to the former class, being nitrogenons substances, while starch, gum, sugar, woody fibre, mucilage, dc., are destitute of nitrogen, or non-nitrogenous.

Only a small quantity of nitrogen is found in regetable substances, and it is derived, in part, at least, from the atmosphere in the form of ammonia. On the other hand, nitrogenous substances form a large proportion of the constituents of the blood of animals and appear in their whole system. As there is a constant waste in the animal and a continual formation of new tissues, - as the whole body is constantly renewed through the agency of the blood which is converted into flesh and muscle,there must be a never failing supply of nourishment, and this nourishment for the higher animals is found, as already intimated, in the nitrogenous elements of plants.

conducted by his gardener, George Sinclair, were detailed in a volume under the title of "Hortus Gramineus Woburnensis." This work, which was the first treatise worthy of mention on this subject, became the text-book on the grasses, and has been followed by most subsequent writers, down to the present time. But these experiments must be regarded as very unsatisfactory, both on account of the imperfections of the methods of arriving at the results, (though they were the best then known, and suggested by Sir Humphrey Davy,) and because each species or variety was cultivated only to a very limited extent. The produce per acre, for instance, was calculated, in most cases, from the yield of four square feet. Besides this, very great diserepancies occur in the volume which ean with diffieulty be accounted for.

The analyses recently made lyy Prof. Way, the distinguished ehemist of the Royal Agricultural Society, are more reliable, in my estimation, than any which can be found, and no treatise on the grasses would be complete without giving the valuable results to which he has arrived. 
For erery ounce of nitrogen which the animal requires to sustain life and health, he must take into the stomach, in the shape of food, such a quantity of regetable substances as will furnish him with an ounce of nitrogen. If we suppose one kind of hay to contain one ounce of nitrogen to the pound, and another to have only half as much, or only an ounce in two pounds, the pound which contains the ounce of nitrogen would go as far to nourish the animal-other things being equalas the two pounds which contain only the same quantity of nitrogen. The importance of woody fibre to act mechanically in giving bulk to the food, is not, of course, to be overlooked.

Nor is this a mere deduction of theory. The experiment has frequently been made, and it is now fully established both by science and experience, that the greater the proportion of nitrogen which any regetable contains, the smaller will be the quantity of that regetable required to nourish the animal body, and the less nitrogen any regetable contains, the greater will be the quantity of it required. Nuscle and flesh are composed of nitrogenous principles, while fat is made up of nón-nitrogenous matter. Erery keeper of stock knows that to feed an animal on oil cake alone, for instance, which is but slightly nitrogenous, might fatten him, but it would not give him strength of muscle or size; while if the same animal be kept on the ccreal grains, as wheat or Indian corn, alone, his size rapidly increases, his muscular system derelops, and he gains flesh without increasing lis fat in proportion. It was with reference to these facts that Boussingault formed his tables of nutritive equivalents, and they agrec rery closely with the results of practical observation.

The non-nitrogenous substances are necessary for the production of fat and to supply the animal body with heat, and thus they meet a want in the animal cconomy, although they do not contribute so directly to nourish and sustain the system. They are, therefore, important in the analyses of articles of food, though not so essential in determining merely their nutritire ralues.

From what has been said, the reader will very readily understand the following tables containing the results of the inrestigations of Prof. Way. The specimens of the various grasses on which his researches were made, were analyzed both 
in their green state as taken from the field, and after being dried at a temperature of $212^{\circ}$ Fahr., a point at which the moisture is found to be entirely expclled and evaporation caases, and the importance of both determinations must be obvious on a moment's reflection.

The names of the natural grasses and the dates of their collection are arranged in the following table:-

Table V. Natural Grasses. Name, and Date of Collection.

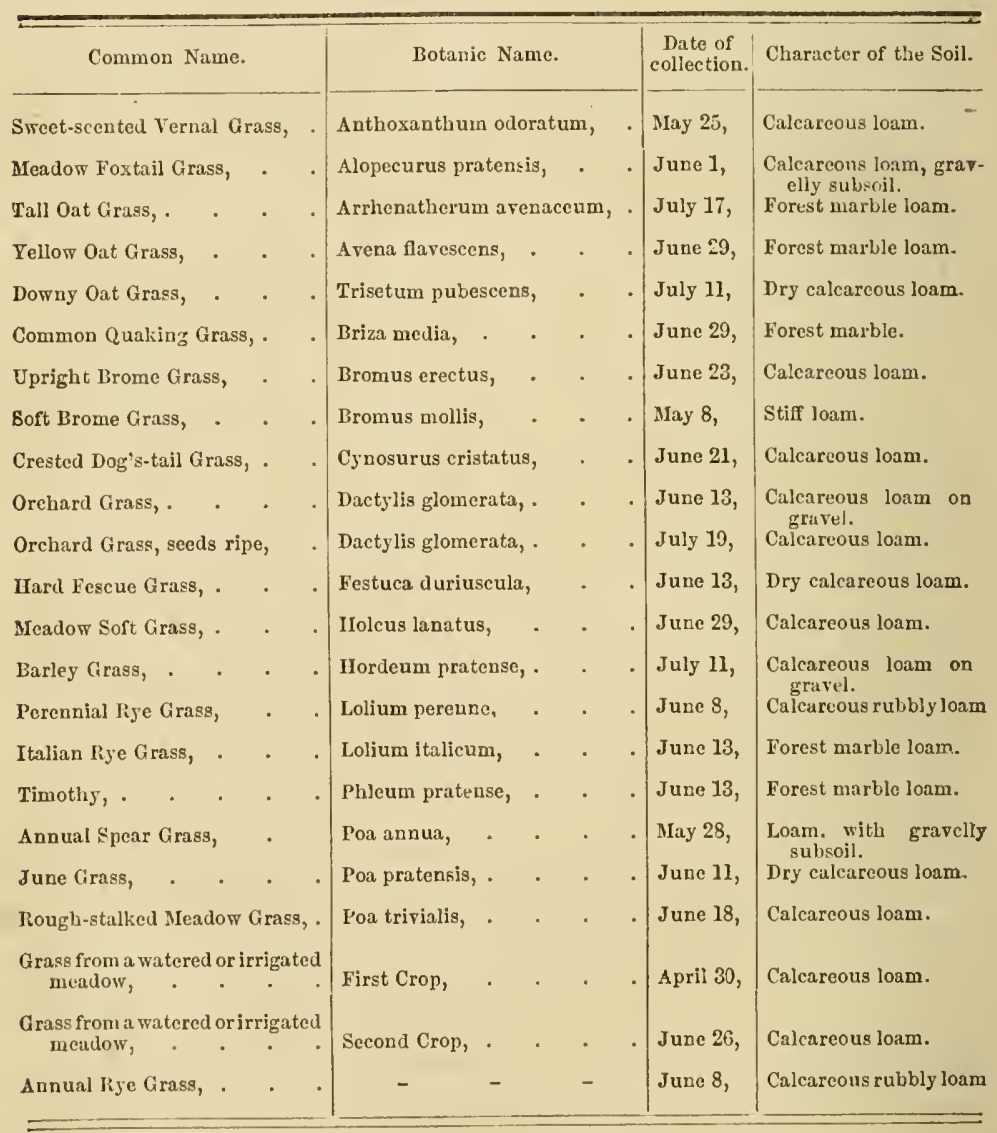

In the same manner, the name and date of collection of each specimen of artificial grass, analyzed, are arranged in table VI. 
Tabre VI. Artificial Grasses. Name, and Date of Collection.

\begin{tabular}{|c|c|c|c|c|c|c|c|c|c|}
\hline \multicolumn{4}{|c|}{ Common Name. } & \multicolumn{3}{|l|}{ Botanic Name. } & \multirow{2}{*}{$\begin{array}{l}\begin{array}{c}\text { Date of } \\
\text { collection. }\end{array} \\
\text { June } 7,\end{array}$} & \multicolumn{2}{|c|}{ Character of Soil. } \\
\hline Red Clover, & . & - & - & Trifolium pratense, & . & - & & Tenacious loam. & \\
\hline Perennial Clover, & . & - & - & Trifolium perenne, & . & - & June 4, & Cilearcous loam. & \\
\hline Criuson Clover, & - & - & - & Trifolium inearnatum & & - & June 4, & Caleareous loam. & \\
\hline Cow Grass, & - & . & - & Trifolium mediun, & - & - & June 7 & Tenacious loam. & \\
\hline Cow Grass, 21 lot & & . & - & Trifolium medium, & . & . & June 21, & Calcareous loain. & \\
\hline Iop trefoil, . & - & - & - & Trifolinm procumbens & & . & June 13 & Calcareous loam. & \\
\hline White Clover, & - & - & - & Trifolium repens, & - & - & June 18 & Forest loam. & \\
\hline Commion reteh, & - & - & . & Vicia sativa, & - & - & June 13, & Forest loain. & \\
\hline Sainfoio, & - & - & - & Onobryclis sativa, & . & . & June 8, & Dry loam. & \\
\hline Lucerne, or Alfa! & fa, & - & - & Medicago satira, . & . & . & June 16 & - & - \\
\hline Black Medick, or & Non & sueh, & - & Medicago lupulina, & - & . & June 6 , & Caleareous loam. & \\
\hline
\end{tabular}

The inquiries of Prof. Way were directed to ascertain

1. The proportion of water in each grass as taken from the field.

2. The proportion of albuminous or flesh-forming substances, inchding, without distinetion, all the nitrogenous principles.

3. The proportion of oily or fatty matters which may be called fat-forming principles.

4. The proportion of elements of respiration, or heat producing principles, among which are included stareh, gum, sugar, pectic acid, fe.; all the non-nitrogenous substances indeed, except fatty matters and woody fibre.

5. The proportion of woody fibre.

6. The amount of mineral matter or ash.

The specimens were picked out, plant by plant, each specimen by itself, from fields in which they were growing naturally, or mixed in the ordinary mode of cultivation, and were not raised expressly for analysis.

These tables of analyses, containing as they do the results of profound investigation, and forming as they do one of the most important contributions recently made to the science of agriculture, are worthy of careful study and will be found to be full of the most valuable practical suggestions.

The results of the analysis of the netural grasses in the green state, are arranged in table VII. as follows :- 
Table VII. Analysis of Natural Grasses. (100 parts as taken green from the field.)

\begin{tabular}{|c|c|c|c|c|c|c|c|c|c|c|c|}
\hline \multicolumn{6}{|c|}{ Name of Grass. } & \multirow{2}{*}{$\begin{array}{l}\stackrel{\text { s. }}{=} \\
80.35\end{array}$} & \multirow{2}{*}{ 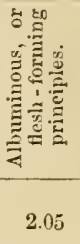 } & \multirow{2}{*}{ 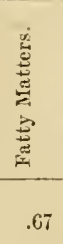 } & \multirow{2}{*}{ 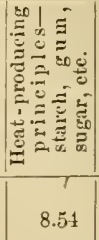 } & \multirow{2}{*}{ 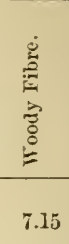 } & \multirow{2}{*}{ 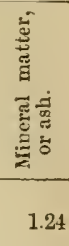 } \\
\hline Swreet-scented Verna & & * & · & · & & & & & & & \\
\hline Headow Foxtail, & & . & . & . & & 80.20 & 2.44 & .52 & 8.59 & 6.70 & 1.55 \\
\hline Tall Oat Grass, & - & . & . & . & & 72.65 & 3.54 & .87 & 11.21 & 9.37 & 2.36 \\
\hline Yellow Oat Grass, & . & . & . & . & & 60.40 & 2.96 & 1.04 & 18.66 & 14.22 & 2.72 \\
\hline Downy Oat Grass, & . & . & . & . & & 61.50 & 3.07 & .92 & 19.16 & 13.31 & 2.01 \\
\hline Quaking Cirass, . & & . & . & . & & 51.85 & 2.93 & 1.45 & 22.60 & 17.00 & 4.17 \\
\hline Upright Brome Gras & & . & . & & & 59.57 & 3.78 & 1.35 & \multicolumn{2}{|c|}{$33 \cdot 19$} & 2.11 \\
\hline Soft Brome Grass, & & . & . & . & & 76.62 & 4.05 & .47 & 9.04 & 8.46 & 1.36 \\
\hline Crested Dog's-tail, & . & . & . & . & & 62.73 & 4.13 & 1.32 & 19.64 & 9.80 & 2.38 \\
\hline Orchard Grass, . & . & . & . & . & & 70.00 & 4.06 & .94 & 13.30 & 10.11 & 1.59 \\
\hline Orehard Grass, seeds & sipe, & . & . & . & & 52.57 & 10.93 & .74 & 12.61 & 20.54 & 2.61 \\
\hline IIard Fescue Grass, & & . & . & . & & 69.33 & 3.70 & 1.02 & 12.46 & 11.83 & 1.66 \\
\hline 3Ieadow Soft Grass, & . & . & . & . & & 69.70 & 3.49 & 1.02 & 11.92 & 11.94 & 1.93 \\
\hline Barley Grass, & . & . & . & . & & 58.85 & 4.59 & .94 & 20.05 & 13.03 & 2.51 \\
\hline Perennial Rige Grass, & & . & . & . & & 71.43 & 337 & .91 & 12.08 & 10.06 & 2.15 \\
\hline Italian Rye Grass, & - & . & : & . & & 75.61 & 2.45 & .80 & 14.11 & 4.82 & 2.21 \\
\hline Timothy Grass, . & . & . & : & . & & 57.21 & 4.86 & 1.50 & 22.85 & 11.32 & 2.26 \\
\hline Annual Spear Grass, & . & . & . & . & & 79.14 & 2.47 & .71 & 10.79 & 6.30 & .59 \\
\hline June Grass, & . & . & - & . & & 67.14 & 3.41 & .86 & 14.15 & 18.49 & 1.95 \\
\hline Rough-stalked Meado & ow Gr & rass, & . & . & & 73.60 & 2.58 & .97 & 10.54 & 10.11 & 2.20 \\
\hline Grass from Irrigated & Neac & dow, & . & . & & $8 \overline{.} .58$ & 3.22 & .81 & 3.98 & 3.13 & 1.28 \\
\hline Grass from Irrigated & Meac & dow, & ed crop & & & 74.53 & 2.78 & .52 & 11.17 & 8.76 & 2.24 \\
\hline Anpual Rye Grass, & 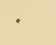 & . & . & . & & 69.00 & 2.96 & .69 & 12.89 & 12.47 & 1.99 \\
\hline
\end{tabular}

A glance at the first column of table VII. will show a striking difference in the pereentage of water, it being as high as 80 in some instances, while it falls as low as 60 , and in one instance to 51, without considering the second specimen of orchard grass-in which the seed was allowed to ripen, when, of course, the amount of water would be much less than at the period of flowering-or the irrigated grasses.

It will he noticed that those grasses which come carliest into flower are generally the most succulent, though this is not uniformly the case. 
It will be seen that the sweet-seented rernal grass and the meadow foxtail contain but 20 parts in 100 , of dry, solic matter, while the yellow oat and the downy oat grasses contain nearly double, or about 40 per ent. This difference, though of no great importance in itself, is of some interest in showing that to judge of the quantity of hay a giren burden of grass will prodnce, it is necessary to consider the species of grass which mainly composes the meadow, since it is evident that a given weiglit of one variety might make double the quantity of the same weight of another.

But the chief interest of the table is to be found in columns three, four and fire. The albuminous or flesh forming principles will be found to be double in some instances what they are in others; and in accordance with the principles laid down in the explanatory remarks which precede the tables, some would appear to be more than twice as nutritive as others, but it should be borne in mind that these differences depend in part on the rariations in the quantity of water, and that the real differences will appear more apparent in the dried specimens.

A glance at table VIII. will show that the percentage of water in the artificial grasses as taken from the field, is greater thain that of the natural grasses under the same circumstances. The percentage of albuminous or flesh forming principles is generally, though by no means uniformly, less than that of our best grasses. Compare red clover, for instance, with Timothy, and the first striking peculiarity is the difference in the amount of water, in the one case excecding 81 per ecnt., learing but 19 per cent. of solid matter from which the flesh forming and other nutritive substances must be drawn, while in Timothy the water amounts to only little orer 57 per cent., learing 43 per cent. of solid substances containing nutritive principles. This is an important difference to begin with. The percentage of flesh forming principles of the two plants does not, at first sight, appear to differ very materially, the clover containing 4.27 the Timothy 4.86 ; but a little consideration of the exceeding ralue of this constituent, will show that the latter has an important advantage in this respect orer the clover. In fatforming principles, the Timothy is more than twice as rich as clover, while in heat-producing principles-also very valuableTimothy far surpasses clover, the one producing 22.85 per cent., 
and the other only 8.45 per cent. Of waste and uscless matter in the shape of woody fibre, Timothy contains the largest per cent., while the larger quantity of mineral matter shows it also to be a greater cxlanuster of the soil. The most valuable practical deductions of a similar nature may be made by comparing these tables.

Table VIII. Analysis of Artificial Grasses. (100 parts, as taken from the ficld).

\begin{tabular}{|c|c|c|c|c|c|c|c|c|c|c|}
\hline Name of $\mathrm{P}$ & lant. & & & & 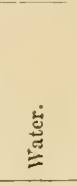 & 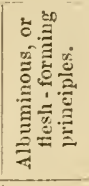 & 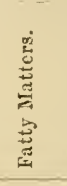 & 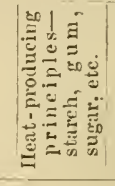 & 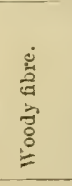 & 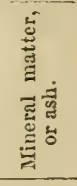 \\
\hline Red Clover, & . & . & . & & 81.01 & 4.27 & .69 & 8.45 & 3.76 & 1.82 \\
\hline Perenzial Clover, & . & . & . & & 81.05 & 3.64 & .78 & 8.04 & 4.91 & 1.58 \\
\hline Crimson Clorer, . & . & . & . & . & 82.14 & 2.96 & .67 & 6.70 & 5.78 & 1.75 \\
\hline Cow Grass, . . & . & . & . & . & 74.10 & 6.39 & .92 & 9.42 & 6.25 & 3.01 \\
\hline Cow Grass, $2 \mathrm{~d}$ specimen, & . & . & . & . & 77.57 & 4.22 & 1.07 & 11.14 & 4.23 & 1.77 \\
\hline Hop Trefoil, . & . & . & . & . & 83.48 & 3.39 & .77 & 7.25 & 3.74 & 1.37 \\
\hline White Clorcr, . & . & . & . & ${ }^{\circ}$ & 79.71 & 3.80 & .89 & 8.14 & 5.33 & 2.08 \\
\hline Common Veteh, . & . & . & . & $\cdot$ & 82.90 & 4.04 & .52 & 6.75 & 4.68 & 1.11 \\
\hline Bainfoin, . . & . & . & . & $\cdot$ & 76.64 & 4.32 & .70 & 10.73 & 5.77 & 1.84 \\
\hline Lucerne, or Alfalfu, & . & . & . & & 69.95 & 3.83 & .82 & 13.62 & 8.74 & 3.04 \\
\hline Elack Medick, or Nonsuc & & . & . & & 76.80 & 5.70 & .94 & 7.73 & 6.32 & 2.51 \\
\hline
\end{tabular}

It will be seen in table IX. that in the ease of orchard grass and the irrigated meadow, the seeds were ripened, and they should not, therefore, be compared with other grasses taken in the blossom, without considering this fact. It will be seen, too, that the specimiens analyzed were in the dry state, much drier than they could be made by the ordinary process of hay making; for however perfectly the hay is cured it will still contain a very considerable perecntage of water, and if artificially dried, as in the trials given above, and then exposed to the air, it will absorb from 10 to 15 per cent. of water, showing that no hay is absolutely dry loy any ordinary processes. In England, the percentage of water in well made hay is about 16, and hay artificially dried will absorb that amount if exposed again to the air. I do not think the pereentage here would be so large, for obvious reasons. In the analysis of the hay of the reed canary grass, 
made by Prof. Horsford and given on a preceding page, the percentage was but 10.24 . That was a well-cured specimen, taken after it had passed the period of blossoming, and the anount of water is, perhaps, slightly below the average.

Table IX. Analysis of Natural Grasses. (100 parts of the grass dried at $212^{\circ}$ Fahr.)

\begin{tabular}{|c|c|c|c|c|c|c|c|c|c|}
\hline \multicolumn{3}{|c|}{ Name of Grass. } & & & 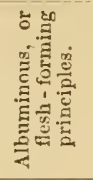 & 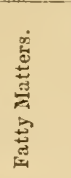 & 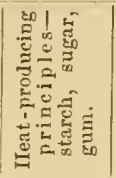 & 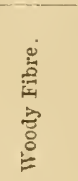 & 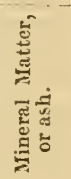 \\
\hline \multicolumn{3}{|c|}{ Swcet-scented Ternal Grass, } & . & $\therefore$ & 10.43 & 3.41 & 43.48 & 36.36 & 6.32 \\
\hline Sicadow Fostail, . & . & . & . & . & 12.32 & 2.92 & 43.12 & $33 . £ 3$ & 7.81 \\
\hline Tall Oat Grass, . & . & . & . & . & 12.95 & 3.19 & 38.03 & 84.24 & 11.59 \\
\hline Yellow Oat Grass, & . & . & . & . & 7.48 & 2.61 & 47.08 & 35.95 & 6.58 \\
\hline Downy Oat Grass, & . & . & . & $\therefore$ & 7.97 & 2.39 & 49.78 & 31.64 & 5.22 \\
\hline Quaking Grass, . & . & . & . & . & 6.08 & 3.01 & 46.95 & 35.30 & 8.66 \\
\hline \multicolumn{2}{|l|}{ Upright Brome Grass, } & . & . & . & 9.44 & 3.33 & \multicolumn{2}{|c|}{$82 \cdot 02$} & 5.21 \\
\hline Soft Brome Grass, & . & . & . & . & 17.29 & 2.11 & 38.66 & 36.12 & 5.82 \\
\hline Crested Dog's-tail, & - & . & . & . & 11.08 & 3.54 & 52.64 & 26.36 & 6.38 \\
\hline Orchard Grass, & . & . & . & - & 13.53 & 3.14 & 44.32 & 33.70 & 5.31 \\
\hline \multicolumn{2}{|c|}{ Orchard Grass, seeds ripe, } & . & . & - & 23.08 & 1.56 & 26.53 & 43.32 & 5.51 \\
\hline Hard Fescue Grass, & . & . & . & . & 12.10 & 3.34 & 40.43 & 33.71 & 5.42 \\
\hline Meadow Soft Grass, & . & . & . & . & 11.52 & 3.56 & 39.25 & 39.30 & 6.37 \\
\hline Meadow Barley Grass, & & . & . & & 11.17 & 2.30 & 46.68 & 31.67 & 6.18 \\
\hline Perennial Rye Grass, & . & . & . & . & 11,85 & 3.17 & 42.24 & 35.20 & 7.54 \\
\hline Italian Rye Grass, & . & - & . & . & 10.10 & 3.27 & 57.82 & 19.76 & 9.05 \\
\hline Timothy, . . & . & . & . & . & 11.36 & 3.55 & 53.35 & 26.46 & 5.28 \\
\hline Annual Spear Grass, & . & - & . & - & 11.83 & 3.42 & 51.70 & 30.22 & 2.83 \\
\hline June Grass, ' & $\cdot$ & & . & . & 10.35 & 2.63 & 43.06 & 38.02 & 5.94 \\
\hline liough-stalked Mfeador & Wras & & . & . & 9.80 & 3.67 & 40.17 & 38.03 & 8.33 \\
\hline Crass from irrigated $\mathrm{m}$ & meado & & . $\quad$. & . & 25.91 & 6.53 & 32.05 & 25.14 & 10.37 \\
\hline Grass from irrigated $\mathrm{m}$ & meador & $\mathrm{w}, 2 \mathrm{~d}$ & l crop, & . & 10.92 & 2.06 & 43.90 & 34.30 & 8.82 \\
\hline
\end{tabular}

It will be seen that a great difference exists in the valuable constituents of the grasses analyzed in this table, ranging as follows :-

\begin{tabular}{|c|c|c|c|}
\hline Flesh-forming principles, & $\begin{array}{r}\text { Lowest. } \\
\text {. } 6.08\end{array}$ & $\begin{array}{c}\text { IIighest. } \\
17.29\end{array}$ & $\begin{array}{c}\text { Average } \\
11.68\end{array}$ \\
\hline Fat-producing principles, . & 2.11 & 3.67 & 2.89 \\
\hline $\begin{array}{c}\text { Heat-giring principles, } \\
16\end{array}$ & 38.03 & 57.82 & 47.92 \\
\hline
\end{tabular}


TABLE X. Analysis of Artificial Grasses. (In 100 parts of the grass dried at $212^{\circ}$ Fahr.)

\begin{tabular}{|c|c|c|c|c|c|c|c|c|c|c|}
\hline \multicolumn{6}{|c|}{ Name of Plant. } & 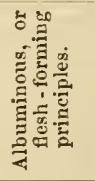 & 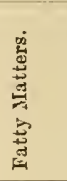 & 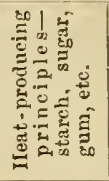 & 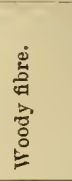 & 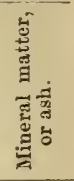 \\
\hline Red Clover, & - & . & - & - & . & 22.55 & 3.67 & 44.47 & 19.75 & 9.56 \\
\hline Perennial Clover, & - & . & - & . & . & 19.18 & 4.09 & 42.42 & 25.96 & 8.35 \\
\hline Crimson Clover, . & . & . & - & . & . & 16.60 & 3.73 & 37.50 & 32.39 & 9.78 \\
\hline Cow Grass, . & . & - & ${ }^{\circ}$ & - & . & 24.33 & 3.57 & 36.36 & 24.14 & 11.60 \\
\hline Cow Grass, $2 \mathrm{~d}$ specir & en, & . & & . & . & 18.77 & 4.77 & 49.65 & 18.84 & 7.97 \\
\hline IIop Trefoil, & - & . & . & . & . & 20.48 & 4.67 & 43.86 & 22.66 & 8.33 \\
\hline White Clover, & . & . & • & . & . & 18.76 & 4.39 & 40.04 & 26.53 & 10.29 \\
\hline Common Teteh, . & . & . & . & . & - & 23.61 & 3.06 & 39.45 & 27.38 & $\cdot 6.50$ \\
\hline Sainfoin, . & . & . & . & . & . & 18.45 & 3.01 & 45.96 & 24.71 & 7.87 \\
\hline Lucerne, or Alfalfa, & $\cdot$ & - & • & $\cdot$ & . & 12.76 & 2.76 & 40.16 & 34.21 & 10.11 \\
\hline Black Mledick, . & . & . & . & . & . & 24.60 & 4.06 & 33.31 & 27.19 & 10.84 \\
\hline
\end{tabular}

A glance at this table will show that the different principles in the artificial grasses vary to a great extent, as follows:-

\begin{tabular}{|c|c|c|c|}
\hline Flesh-forming principles, & $\begin{array}{l}\text { Lowest. } \\
12.76\end{array}$ & $\begin{array}{l}\text { IIighest. } \\
24.60\end{array}$ & $\begin{array}{c}\text { A verage } \\
18.68\end{array}$ \\
\hline Fat-producing principles, & 2.76 & 4.77 & 3.76 \\
\hline Heat-giving principles, & 33.31 & 49.65 & 41.48 \\
\hline
\end{tabular}

The difference in composition exhibited in the natural grasses of table IX. are very marked, and of course, the value of the grasses as compared with each other must vary greatly. Still, the practical value of a grass depends somewhat upon circumstances which cannot be analyzed, such as the period at which it arrives at maturity, and the particular soil and location of the farmer. It might happen that a grass not in itself so rich in nutritive qualities as another, would be preferred on account of its coming to maturity just at the time when the farmer most needed it. But the particular value of this table is, that it shows the comparative nutritive qualities of the grasses, since all the specimens were collected and investigated in the same manner, at the same period of growth, - or as nearly as possible,-when in the flower, so that whatever sources of error 
might exist to modify the results, they would naturally apply to all alike.

The grasses from the irrigated meadow consisted principally of June, or Kentucky blue grass, rough stalked meadow grass, perenuial rye grass, meadow soft grass, barley grass, incadow oat grass and a few other species, and it will be noticed that in combination they abound in flesh and fat-forming principles to a greater extent than we should be led to suppose from the composition of any one of them alone.

Our favorite Timothy compares very favorably with the other grasses, containing a less percentage of useless matter as woody fibre, than any other, except Italian rye grass and crested dog'stail, a grass not common with us, and the irrigated grasses. In point of soluble, heat-producing principles, sugar, gum and starch, it is surpassed by the Italian rye grass, but by no others. The analyses of this grass in its green and dry states in tables VII. and IX., fully justify the preference which we have long shown for the use of Timothy; for, as taken from the field at the time of blossoming, it will be found to contain less water, (table VII.,) a greater percentage of flesh and fat-forming principles, and less uscless matter in the shape of woody fibre, than most of the other grasses. The deductions of science certainly correspond, in this case, with the results of practice.

A comparison of tables VII. and IX. with tables VIII. and X. will show the comparative advantages of the use of the artificial grasses, in point of albuminous or flesh-forming principles and fatty matters. The carbonaceous or heat-producing principles remain nearly the same throughout, while the percentage of waste matter or woody fibre is less than in the natural grasses. This is an important fact, worthy of the careful consideration of the farmer.

In the sixth column of table IX. will be found the percentage of ash of each of the grasses analyzed. Table XI. contains a still further analysis of this ash, which gives all the inorganic constituents which the plant derives from the soil and the manures furnished to it. It is important and suggestive to one who will examine it carefully, as indicating the kind of manure which in many cases it may be desirable to apply.

The first peculiarity which plainly appears from a glance at the ash analyses, is the very large percentage of silicates and 
TABLE XI. Analysis of the Ash of some of the Natural and Artificial Grasses.

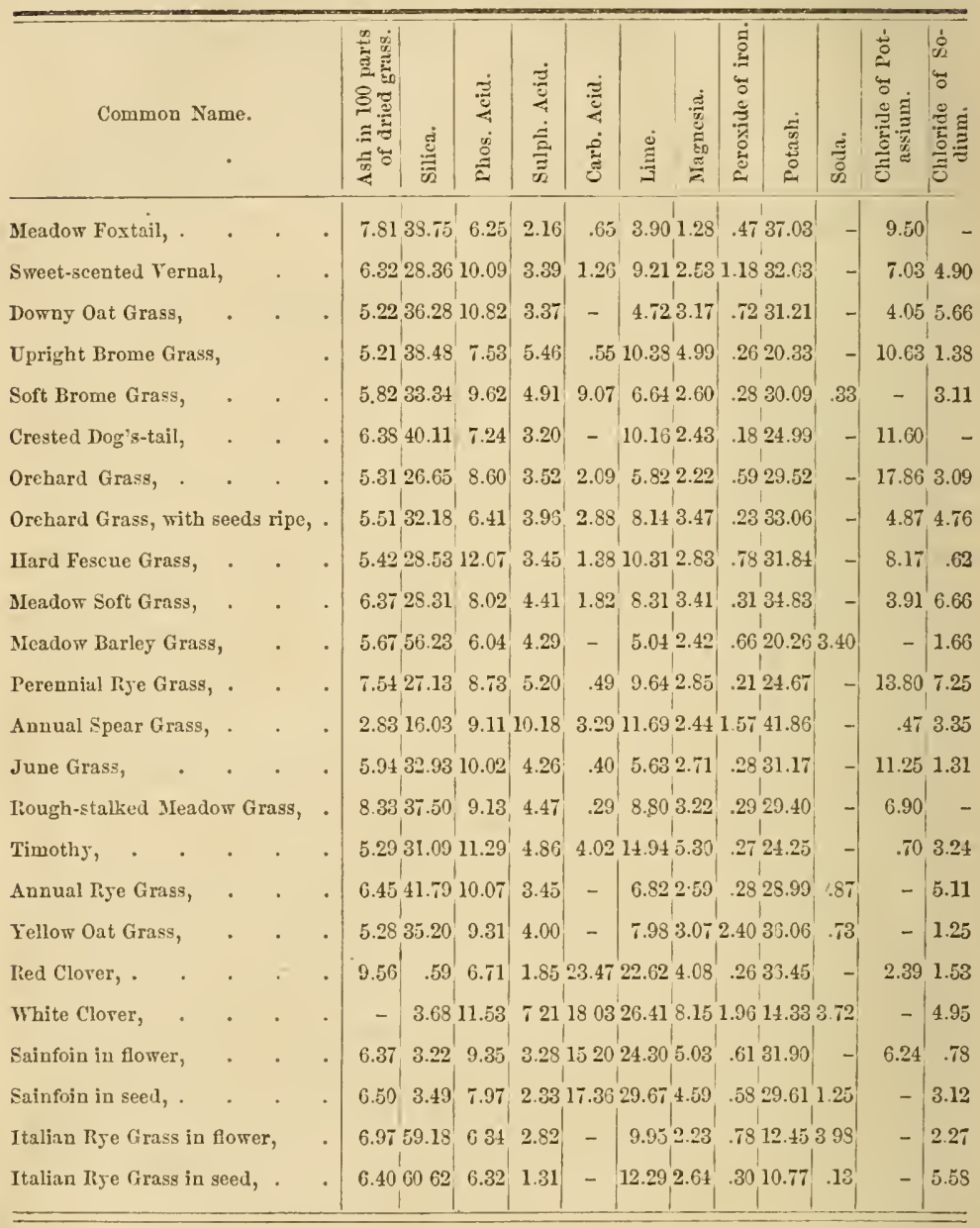

potash contained in the natural grasses, and the rery small comparative percentage of silica in the artificial grasses, the red and white clovers. The large pereentage of lime and carbonic acid attract our attention in the latter. 'This table is exceedingly valuable as suggesting the proper course of manuring fol the most successful cultivation of the rarious crops contained in it.

If now we cast our eye at the analysis of some of our com- 
TABLE XII. Analysis of Specimens of Weeds, as taken from the ficld, and when dried.

\begin{tabular}{|c|c|c|c|c|c|c|c|}
\hline Name of Plant. & 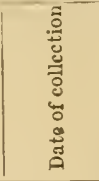 & 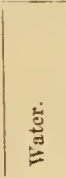 & 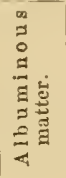 & 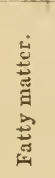 & 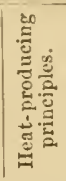 & 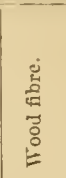 & 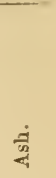 \\
\hline Ox-ese Daisy, (Crysanthemum leucanthemum, ) & June 23, & 71.85 & 2.12 & .999 & 12.64 & 10.51 & 1.86 \\
\hline Yellow Buttereup, (Ranunculus acris,) & June 13, & 83.15 & 1.18 & .507 & 6.26 & 3.00 & .91 \\
\hline $\begin{array}{l}\text { Sorrel, (Rumex acetosa, }) . \\
\text { DRIEd SPEcrmexs of THE SAME. }\end{array}$ & July 4, & 75.37 & 1.90 & .545 & 7.62 & 13.04 & 1.51 \\
\hline 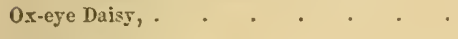 & $-\quad-$ & - & 7.53 & 3.49 & 45.02 & 37.33 & 6.63 \\
\hline Buttereup, & - & - & 9.98 & 4.28 & 52.69 & 25.34 & 7.71 \\
\hline Sorrel, & & - & 7.71 & 2.19 & 46.82 & 37.16 & 6.12 \\
\hline
\end{tabular}

mon weeds, we shall see how far superior the cultivated grasses are in nitrogenoụs or nutritive principles.

The albuminous principles are rery much less than in either the natural or the artificial grasses.

A line of investigation, both scientific and practical, equally interesting and raluable with the foregoing, would lead into the comparative nutritive equiralents of hay and other feeding substances. This is not the place to discuss that sulject in full, the line of our present inquiry embracing only the comparative nutritive values of the grasses themselves. For convenience of reference, however, I subjoin the following table, (XIII.,) embracing the results of the profoundest researches of many distinguished chemists and practical men, both in the laboratory and the barn. Bonssingault and others in France, and Fresenius, Thaer and others in Germany, hare devoted to these and similar investigations the best part of their lives.

It is necessary to remark that tables of nutritive equivalents are liable to imperfections, on account of sources of error which must exist in the nature of things, as difference of soil, climate, season, imperfection of methods of analysis, \&e.; but making all allowance for these, and admitting that the table camnot be absolutely, and literally correct or perfect, it possesses great practical ralue and interest as giring a good gencral iden of the relative valuc for feeding purposes, of various agricultural products. 
In regard to the mutritive value, as based on the amount of nitrogen or nitrogenous compounds, it may be remarked that the latest and most careful experiments, conducted by most experienced and competent experimenters, tend to show that this basis is correct, so far as it can be applied to substances so analogous in composition that they can be included in one group; as for example, the different root crops possess a nutritive value in proportion to the amount of nitrogen they contain, but the nutritive value of a root ought not to be compared with a succulent regetable, like clover, for instance, by the proportion of nitrogen in each, merely, without taking into consideration other properties. In other words, roots may be compared with each other on that basis merely, and grasses with each other, and leguminous plants with each other, but not root crops and grasses. This fact is alluded to as a possible source of error in some of the earlier researches of Boussingault, and not as materially affecting the practical value of the table.

The mode of using table XIII. is very simple. Good upland meadow hay,-or what would be called in New England, good English hay,-is taken as a standard of comparison. Now if we wished to produce the same results with carrots as with one hundred pounds of good, arerage English hay, we must use, according to Boussingault's column of equivalents, 382 pounds of carrots, or for each pound of hay, 3.82 pounds of carrots, and according to the practical experiments mentioned, 366 pounds, 250 pounds, 225 pounds, 300 pounds, and so on, to each 100 pounds of hay.

According to the theoretical values of Boussingault, 100 pounds of hay are equal in feeding qualities to 65 pounds of barley, 60 pounds of oats, 58 pounds of rye, or 55 pounds of wheat. While, according to the experiments of Thaer, 100 pounds of liay produced the same effect as 76 pounds of barley, 86 pounds of oats, 71 pounds of rye, 64 pounds of wheat.

With regard to the analyses of tables VII., VIII., IX. and X., some allowance should undoubtedly be made for differenee of elimate, since it is well known that grasses, as well as other plants, grown rapidly in a hot sun, which we usually have in the months of May, June and July, contain a much larger amount of nutritive and saccharine matter than those grown slower and in a greater amount of available moisture both in 


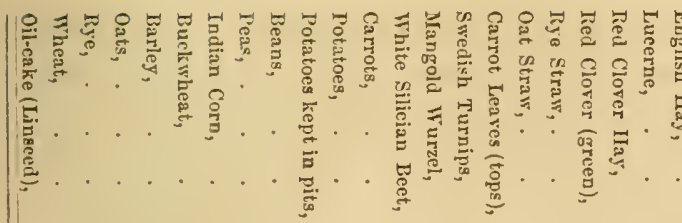

ஸち

Water in 100

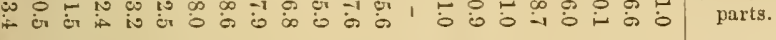

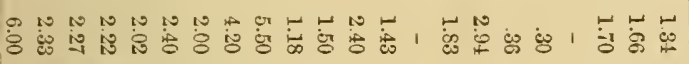

Nitrogen in 100 parts of drieul substance.

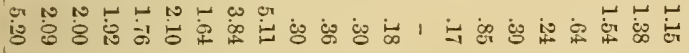

Nitrogen in 100 parts of undried substance.

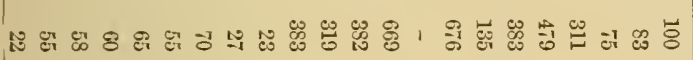

Nutritive equivalent.

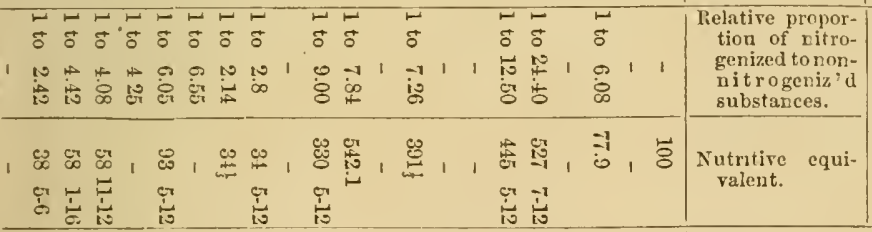

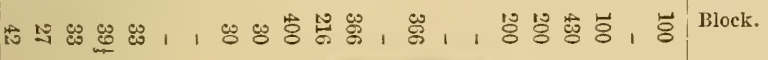

若 던

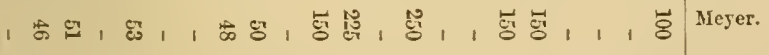

, 엄

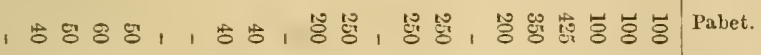

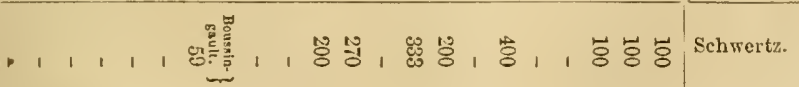

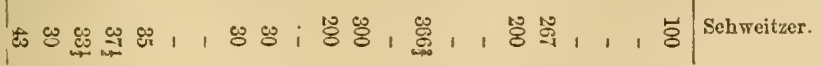


the atmosphere and the soil, which is ordinarily present in the climate of England. Every observing farmer knows that grasses grown on our low, reclaimed swamp lands, for instance, make less milk, and less flesh and fat in animals, than the same species grown on our dry, upland soils. The same difference must exist, to some extent, between our grasses and the grasses grown in a comparatively moist climate, where they have the advantage of more frequent rains, which push them to a more complete development and give them greater luxuriance, increasing, of course, the quantity of their produce, while their quality cannot be improved in the points alluded to. This subject will come more properly under diseussion in treating of the

\section{INFLUENCE OF THE SEASONS.}

We now come to consider the influence which the season or the climate has upon the quantity and nutritive quality of grass. Before entering upon this topic, it is proper to remark, that in order to bring together the practical wisdom and judgment of some of the best farmers in the State, as well as to be able to present some statistical information in regard to the product of grass and hay for the past season, I directed the following circular to one or more farmers in every town in Massaclusetts, asking for replies from each.

\section{Board of Agriculture, State House, Boston, Sept. 1, 1856,}

Dear Sir :-Will you have the goodness to reply to the following inquiries in reference to the grass and hay crop of your town, according to the best of your judgment and experience? If circumstances prevent your giving it personal attention, will you be kind enough to put it into the hands of some one interested in the subject in your neighborhood, who will do me the favor to answer it?

1. What was the estimated yield of grass and hay in your town this season, as compared with others? If abore or below the average, how much?

2. What, in your opinion, is the effect of a wet or a dry season on the quality of grass and hay? Is grass grown in the shade as good as that grown in the sun, and what is the difference?

[This question embraces the intrinsic value of hay this season as compared with the crops of 1854 and 1855 , both comparatively dry seasons, while this has been unusually wet in most parts of the State.] 
3. In what month do you profer to sead down land designed for mowing. and what is the reason of your preference?

4. What rarictics of grass sced do you usually sow for mowing, and what for permanent pasturage, and in what quantities and proportions, per acre?

5. Do you prefer to sow grass secd alone in either case, or with some variety of grain? If the latter, why, and with what grain?

6. Have you cultivated or raised orchard, fowl meadow, or blue joint grisses, and with what result as compared with the yield and value of other grisses?

7. At what stage of growth do you prefor to cut grass to make into English and into swale hay, and what is the reason for your preference?

8. What is the best mode of making hay from Timothy, from redtop, and from wet meadow grass, and at what state of dryness do you consilicr it made, or fit to get into the barn?

[This question embraces, to some extent, the time taken to make it under ordinary circumstances of good weather, \&c. This, of course, varies greatly, but some farmers would dry grass cut in the blosson two good hay days, while others would prefer to cure it less, and get it in on the day it was cut.]

9. Will you state in detail how you make or cure clover, and how, when so cured, it compares in value with other kinds of hay to feed out to farm stock?

10. Have you used hay caps, and if so, with what result, in point of cconomy? How were they made ind at what cost?

11. Have you used a mowing machine, and if so, what patent, with what power, and with what advantage?

12. At what height from the ground do you prefer to have your grass cut, and why?

13. Have you used a horse-ralse, and if so, what patent, and with what adrantage?

14. Do you feed off the after growth of your mowing lands in the fall? Do you think it an injury or a benefit to the field to feed it off?

15. Do you top-dress your mowing or pasture lands, and if so, what manure do you prefer to use, at what time, and in what quantities do you apply it?

16. What is the best mode of renovating old worn out pasture lands?

17. If you have any experience in ditching and draining wet meadow, or ditching or diking salt marsh, will you state the result, and the comparative value of the grass before and after the operation?

18. What are the most valuable varieties of salt m.ırsh grasses, and how does the hay made from them csmpare in value with good English hay? 
19. Have you any experience in irrigating mowing or pasture lands, and if so, what is the result?

20. Do you prefer to salt your hay when putting into the barn, and if so, what quantity do you use, per ton?

21. What do you consider the best mode of destroying couch or twitch grass ?

22. What is the best mode of destroying the white weed or ox-eye daisy ?

23. Will you give any other details not suggested by the above, which, in your opinion, may be considered importunt, in regard to this crop, and particularly if you have experimented with any rarictics of grass not in gencral cultivation, such as lucerne or alfalfa, rye grass, brome grass, Kentueky blue grass, \&c., will you state the results as fully as possible? If you have any rarictics of grass found to be valuable but not in gencral cultivation, the names of which are not known to you, will you send them to this office where the names wil! be given?

Very respectfully, your obedient servant,

CHARLES I. FLINT, Secretary of the Board of Agricullure.

I am indebted to the kindness of many enterprising and intelligent farmers for full and valuable answers from more than two hundred towns in the State, and these alone would make a raluable volume of themselves. I can, of course, do no more than extract from them as frecly as space will permit, which I shall do at greater length in the subsequent sections.

No erop, perhaps, is more dependent on the seasons than the grasses. Every farmer knows that a moist spring, with raius erenly distributed orer the months of April, May and June, will insure him the most luxuriant crops of grass and hay ; and he knows, also, that a dry, cold spring is fatal to their rapid and healthy development, and that he must, in such a spring, expect a comparatively small crop. These and many similar facts are familiar to the commonest practical observation.

It lias also been found by observation that the grasses will vegetate when the temperature of the air is abore the freezing point of water, $32^{\circ}$ Fahrenheit, provided the temperature of the soil ranges from $35^{\circ}$ to $40{ }^{\circ}$ while a lower temperature checks their growth. Vegetation, at temperatures higher than these, depends much on the amount of moisture and heat, both 
of the soil and the atmosphere. Grass will not regetate when the temperature of the air is higher than $66^{\circ}$ unless the soil is very moist. When the vapor of the air is at its maximum, or when the air is saturated with moisture, regetation adrances with the greatest rapidity, and this most frequently liappens with us in the earlier growing months, April, May and June. But when the moisture in the atmosphere is slight, and the soil becomes dry, and the subsoil is porous, the turf of our fields and pastures sufiers from the drought, and scarcely a year passes orer us when this does not happen.

A writer in the Journal of the Royal Agricultural Society, (quoted in the Farmers' Magazine, Vol. ix., No.5, Third Series,) after many careful observations, comes to the conclusion, First. That the growth of grass is always proportionate to the heat of the air, if a sufficiency of moisture be present in the atmosphere. second. That in the climate of England the moisture present is rarely sufficient to allow the temperature to have full effect, when that tmperature cxcesls $56^{\circ}$, but that if moisture be artificially supplied, as by irrigation, to catch water meadows, that then vegetation will still proceed in proportion to the heat. Third. That when the temperature of the air is between $36^{\circ}$ and $41^{\circ}$, the grass will only regetate with a fifth part of the foree that it will when the temperature is $56^{\circ}$. Thus the land that will keep ten sheep per acre in the latter case, will only $k$ sep two in he forme: That from $41^{\circ}$ to $46^{\circ}$ its grouth is two-fifths, or double that of its growth when the temperature is under $41^{\circ}$, and it will then ke $p$ four sheep instead of two. Again, from $46^{\circ}$ to $53^{\circ}$, its growth will ris e to seren- ${ }^{-}$nths or it will keep on the same ground from fire to seren sheep, and from $50^{\circ}$ to $66^{\circ}$, it gener 11 - mless assister by an artificial addition of moisture-arrives at its maximum; but if the month of June be very moist, it will cont nue to grow with an increase of force up to $60^{\circ}$.

Our climate is very different from that of England. The evaporation from the soil is ordinarily very much more rapid, and the actual amount of moisture in the air is greater, since it is well established that the evaporation is in proportion to the height of the temperature and the extent of water or land surface; that in the temperate zones it amounts to about thirtyseven inches a year, while in the tropics it rises to from ninety 
to one hundred inches, and that the atmosphere when at the freczing point contains about a two-hundredth part of its weight of water, while at $52^{\circ}$ it contains a lundredth part, or twice as much; at $74^{\circ}$, a fiftieth part, or four times as much, and at $98^{\circ}$, a twenty-fifth part, or eight times as much, and so on in that ratio. Now although the mean annual temperature of the two countries is about the same,-it being near London about $48^{\circ}$ $5^{\prime}$, and at Boston $48^{\circ} 9^{\prime}$, -yet the temperature of the growing months of the two countries presents a marked difference, the mean temperature of crery one being with us much higher. But the climate of England is proverbially moist, notwithstanding that the mean annual fall of rain near London is only little over twenty-five inches, while the quantity which falls at Boston is orer forty-two inclies. The amount of sensible moisture of the atmosphere is greater in England than here, though the actual amount existing in our atmosphere must excee that of the atmosphere even in the eastem part of England. Our soil is consequently dryer, and unless we have frequent rains vegetation suffers sooner, and the growth of grass is liable to be checked for the want of moisture. This actually happens more or less nearly every year. But the spring of the past year was an exception, for the quantity of rain in most parts of the State was no only somewhat larger than usual, but it was well distributed over the spring months; that is, it fell frequently and in small quantities. This, as is usually the case, caused an early and remarkably luxuriant growth of grass, while the quality was not generally considered so good as the average. It may be laid down as a well-fixed principle, that the grass crop is better from large quantities of rain falling at once and at longer intervils, - provided it does not come in torrents to prostrate the erop, and that the intervals are not so long as to produce droughts, which are always attended with deleterious effects, - than 'from smaller quantities falling with greater frequenc $j$. The quantity in the latter ease will not ordinarily be so great as in the former, but it is more than compensated, it is thought, by the increased value. More accurate statistics will throw light on this subject.

As a means of comparison, the following table of the ment monthly temperature and rain at the observatory at Cambridge, during the growing months of 1854 ,' 55 and ' 56 , will be found 
conrenient. The observations were made four times a day, at sumrise, 9 A. M., 8 and 9 P. M. The latitude being $42^{\circ} 22^{\prime}$ $48^{\prime \prime}$, the longitude $71^{\circ} 1^{\prime}$.

\begin{tabular}{|c|c|c|c|c|c|c|c|c|}
\hline \multicolumn{2}{|c|}{ Months. } & & $\begin{array}{l}\text { Mean Temp. } \\
\text { in } 1854 .\end{array}$ & $\begin{array}{l}\text { lain in } \\
\text { 1854. }\end{array}$ & $\begin{array}{c}\text { Alean Temp. } \\
\text { in } 1855 .\end{array}$ & $\begin{array}{l}\text { Rain: in } \\
\text { 1855. }\end{array}$ & $\begin{array}{l}\text { Jlean Temp. } \\
\text { in } 1856 .\end{array}$ & $\begin{array}{l}\text { kain in } \\
1856 .\end{array}$ \\
\hline March, & - & & $33^{\circ} .1$ & 2.919 & $32^{\circ} .31$ & $\begin{array}{l}\text { Inches: } \\
1.1599\end{array}$ & $26^{\circ} .98$ & $\begin{array}{l}\text { Inthes. } \\
0.970\end{array}$ \\
\hline April, & . & & $42^{\circ} .9$ & 4.512 & $41^{\circ} .08$ & 3.990 & $45^{\circ} .82$ & 3.732 \\
\hline May, . & - & & $57^{\circ} .7$ & 5.453 & $53^{\circ} .40$ & 1.501 & $52^{\circ} .55$ & 6.732 \\
\hline June, & & & $65^{\circ} .9$ & $3.58 \pi$ & $65^{\circ} .48$ & 3.581 & $6 S^{\circ} .08$ & 2.869 \\
\hline July, . & & & $7: 20.9$ & 3.239 & $72^{\circ} .24$ & 4.845 & 720.76 & 4.243 \\
\hline August, & & & $68^{\circ} .6$ & 0.351 & $67^{\circ} .31$ & 2.270 & $67^{\circ} .31$ & 14.981 \\
\hline Septembe & & & $61^{\circ} .4$ & 4.360 & $61^{\circ} .45$ & 1.216 & $62^{\circ} .98$ & - \\
\hline
\end{tabular}

The mean temperature and the rain at Amherst, during the growing months of 1856 , was as follows:-

\begin{tabular}{|c|c|c|c|c|c|c|c|c|c|c|c|}
\hline & & emper: & atur & & & $A$ & Anoun & tof & Rain & & $\begin{array}{l}\text { Average of } \\
18 \text { years. }\end{array}$ \\
\hline AIarch, & - & . & . & . & $\begin{array}{r}\text { Fals. } \\
20.83\end{array}$ & March, & . & . & . & $\begin{array}{l}\text { Inches. } \\
1.118\end{array}$ & $\begin{array}{l}\text { Inches. } \\
3.05\end{array}$ \\
\hline April, . . & . & . & . & . & $46^{\circ} .14$ & April, . & . . & . & . & . 2.510 & 3.27 \\
\hline May, . & . & . & . & . & $55^{\circ} .55$ & May, . . & . . & . & . & . 5.313 & 3.91 \\
\hline June, · · & . & . & . & . & $68^{\circ} .66$ & June, . . & . & . & . & . 1.920 & 3.22 \\
\hline July, . & . & . & . & . & $7 \cdot 2 \circ .93$ & July, . & . . & 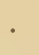 & . & . 1.955 & 4.05 \\
\hline Auggust, & . & . & . & . & $66^{\circ} .19$ & Aurust, & . . & $\cdot$ & . & 12.132 & 4.10 \\
\hline September, & 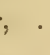 & . & - & . & $60^{\circ} .79$ & September, & , . & . & . & . 3.472 & 3.26 \\
\hline
\end{tabular}

'The first of these places represcnts the castern section of the State, the second, the western; and observations made at Boston, at Bradford, at Salem and elsewhere in the castern part, do not muteriully differ from those at Cambridge, while the observa- 
tions at Williamstown and at Albany, N. Y., do not differ materially, so far as practical dednctions are concerned, from those at Amlerst.

The amount of rain at Worcester, in the central section, in $1854, ' 55$ and '50, was as follows:-

\begin{tabular}{|c|c|c|c|c|c|c|c|c|c|c|c|}
\hline & & ont? & & & & & & 1854. & 1855. & 1856. & $\begin{array}{l}\text { Average for } \\
15 \text { ycars. }\end{array}$ \\
\hline March, . & . & . & & . & & . & . & $\begin{array}{l}\text { Inclics. } \\
: 3.45\end{array}$ & $\begin{array}{c}\text { Inclies. } \\
.23\end{array}$ & $\begin{array}{c}\text { Inclies. } \\
1.69\end{array}$ & $\begin{array}{c}\text { Inehes. } \\
3.29\end{array}$ \\
\hline April, & . & . & & . & & . & . & 6.69 & 5.39 & 3.34 & 3.98 \\
\hline May, . & . & . & & . & & . & . & 6.78 & 1.64 & 6.55 & 4.36 \\
\hline June, . . & . & . & & . & & . & . & 3.05 & 4.19 & 1.14 & 2.93 \\
\hline July, . & . & . & & . & & . & . & 5.68 & 9.40 & 2.68 & 3.70 \\
\hline Aug̣ust, . & . & . & & . & & . & . & .35 & 4.06 & 13.14 & 5.58 \\
\hline September & & . & . & . & & . & . & 5.53 & .20 & 3.39 & 3.47 \\
\hline
\end{tabular}

The amount of rain at Providence, R. I., on our sonthern border, was as follows:-

\begin{tabular}{|c|c|c|c|c|c|c|c|c|c|c|}
\hline \multicolumn{9}{|c|}{ Months. } & \multirow{2}{*}{$\begin{array}{c}\text { For } 1856 . \\
\begin{array}{c}\text { Inches. } \\
2.80\end{array}\end{array}$} & \multirow{2}{*}{$\begin{array}{c}\begin{array}{c}\text { A verage of } 25 \\
\text { years. }\end{array} \\
\begin{array}{c}\text { Inclees. } \\
3.57\end{array}\end{array}$} \\
\hline April, & . & . & . & . & . & . & . & . & & \\
\hline Alay, & . & . & . & . & . & . & . & . & 4.10 & 3.33 \\
\hline June, & . & . & . & . & . & . & . & . & 2.47 & 2.95 \\
\hline July, & . & . & . & . & . & . & . & . & 4.20 & 2.91 \\
\hline \multirow[t]{2}{*}{ August, } & & . & . & . & . & . & . & . & 5.75 & 3.70 \\
\hline & & & & & & & & & 19.32 & 16.46 \\
\hline
\end{tabular}

The amount of rain which fell at Bradford, in Essex county, in the month of $A$ ugust alone, was sixteen inches, the greatest, probably, ever known in one month in New England, while at Nantucket it was but a fraction over one inch; so that while 
the vicinity of Boston and the eastern part of the State, generally, was abundantly supplied, the wet meadows being flooded, and thousands of tons of swale hay ruined, the island of Nantucket and some parts of Barnstable and Plymouth counties were suffering sererely from drought, regetation being entirely parelicel up.

So great is the dependence of the grasses upon heat and moisture combined, that, knowing the results of observations of the thermometer and the rain gange in any section, during the three growing months of $\Lambda$ pril, May and June, one might predict with great certainty the results of the harrest in that section; and, on the other liand, the returns of practical farmcrs in different sections of the State, indicate so clearly and uniformly the excess above the arerage, or the partial failure of the crop, that a meteorological map of the State might be constructed from thicm.

As miglit be expected, therefore, from what has already been said, the yicld of grass and hay throughout most parts of this State during the past year, has been somewhat above the average, the best judges estimating the excess rariously from onc-cighth to onc-half, and it has, doubtless, in some localities, reached this latter estimate, though the general arcrage was not, probably, orer an eighth abore that of other years.

It may be inferred, also, from what has becu said, that the quality was not quite equal to the arerage, and this was unquestionably the casc, where the excess in quantity was due to the excess of moisture and the rains.

The remarks of an experienced, practical farmer of Kentucky, express very well the general estimate made by our farmers in reply to the sceond question proposed in the abore circular. "Just so far," says he, "as there is shade, is the grass deficient in saccharine and nutritions qualities; that grass which is most exposed to the sun heing hest. Woodland pastures will keep young stock growing and old ones on foot, but will not fatten them. A threc-ycar old Durham will get 'stall fat "in a year on open blue grass." And so a farmer of Hampshire county, says: "Grass grown in the sliade is lighter and does not contain so much nutriment. Wet scasons increase the weight and bulk of the crop, but the same weight does not contain the amount of nutritive matter of hay raised in a dry 
season. And another of Worecster county: "Hay grown in a dry season contains more nutriment. This is particularly noticealle in the condition of cattle in the spring following a dry season. I do not consider grass grown in a dense sliade worth orer half price;" while a farmer of great observation, in Middlesce connty, says: "From an expericnce of fifty years in making hay, and thirty-five in feeding it ont and selling it, I should say that in a wet season I nerer found any thing like so much leart or nutriment in liay as in a dry one. Grass grown under a thick, shady tree is not worth one-half as much as that grown in the sun. The grass this year in this town was well set in the spring and grew very quick when the warm weather came on, but still we had much good, warm sun to bring it to maturity, and I think it will spend pretty well, but probably not quite as well as the same bulk last year. Since tile filth of September we cut our salt hay in this town and nerer found it cleaner or better, and I think it will spend well." And another practical farmer remarks: "I think grass and hay are not so good in a wet season. We lose about one-third in the quality of what we gain in the quantity. Grass grown in the shade is not worth more than two-thirds as 'much as that grown in the sun."

It is not necessary to multiply the authorities of practical farmers on this point, since they uniformly coincide with the testimony giren abore, and it may be regarded as fully established as the result both of scientific investigations and of practical experience, that botl the quantity and the quality of grass are in proportion to the heat or sunlight and the moisture in which it is girown.

What has been said will explain the suggestion in the last section with respect to the allomance which it may be proper to make in the analyses of grass grown in a climate of less heat and loss sunshine than onr own. It will also lead to the conclusion that our own grasses grown on low, moist lands, are neitler so sweet nor so mutritious as the same species grown oil higher and dryer soils; and it is a fact which has fallen under the observation of practical farmers, that the grasses on low lands do not produce so much nor so good a quality of milk, nor so much fat in animals as the same species of grass grown on upland soils. 
Closely commected with the influence of the seasons is the

\section{TIME FOR SOWING GRASS SEED.}

More than sixty years ago careful experiments were made in this State, in the hope of obtaining such information as would settle the question as to the best time of sowing grass seed, and the practice of secding down in the fall was then commenced by a few individuals. At and before that time, the practice of soming in the spring was unirersal, and the same custom has generally prevailed till within a very few years. Both the practice and the opinion of the best practical farmers among us have changed to a considerable extent, and it is now commonly thought best to sow grass seed in the fall, early in Septemher, if possible, mixing no grain or any thing else with it, though there are, and always will be, some cases where the practice of sowing in the spring with grain is ennrenicnt and judicious. There can be no doubt that it is, in most cases, an injury to both erops to sow them together. The following statement of an experienced and successful farmer will enable us to comprehend how the change was brought about, though others had tried the same experiment long before him. "More than twenty years ago we had sereral dry summers, in the springs of which I had sown grass seed with rye, barley and sometimes wheat and lost most of my seed by the drought. I could serape it up, the plants boing dead and dry, when small. Since that time I have universally ploughed after haying and suwed Timothy grass and redtop.,"

Other farmers probably experienced the same difficulty and came to the same conclusion. Our seasons differ greatly to be sure, but it is now well understood that we must calculate on a drought in some part of the summer, and grass will suffer more from drought than from frost. Hence the propriety of fall sowing. There are some localities, undoubtedly, where spring sowing with grain is best, on the whole, as in the soutin-eastern sections of the State, along the coast, where on account of the proximity of the sea, the ground is often but slightly covered and protected with snow; yet even there, some farmers say it is better to seed in August and September. Few general rules 
are of universal application in agriculture, and the farmer must constantly exercise sound judgment and common sonse. One practical farmer of Essex, in answer to the circular, says : "I prefer Angust, because I think it less liable to winter-kill than summer-kill. And another greater reason is, that in fall secding I get rid of a crop of weeds, while in spring secding my ground is seeded with them." An experienced farmer of Hampshire county, writes: "I rather prefer the last week in August for seeding down land. The reason is, that we frequently lave a summer drought which kills out the young grass." One of the best farmers of Middlesex, says: "Whon sown alone I prefer from the 20th of August to the 20 th of September. If sown sooner, the summer droughts are apt to injure the young blades; if later, they do not liare a chance to expand and arrive at that degrec of maturity necessary for a good crop the ensuing season." He says, also, that if in any case it is found necessary to sow with grain, it should be in the spring and not in the fall. An experienced practical farmer of Essex county, recommends "The latter part of Angust and the month of September for seeding down land to grass for mowing, unless that season slould be very dry; in that case, sow so soon after a.rain as may be. I do not think it adrisable to sow grass seed when the earth is very dry, as some of it may, by the moisture brought up in preparing the land, sprout, but not having continued moisture to support it, will wither away, while some of the lighter seeds will, perhaps, swell by moisture, but fail to sprout for a lack of nourishment, and consequently perish, while others will be blown away by the winds. The plant from seed sown in August or September, if the scason is moist, will take deep root and be prepared to withstand the changes of winter. Grass secd sown with grain in the spring is liable to be killed in the lot days of July and August, about the time of cutting the grain, particularly on light, sandy or gravelly lands. Clover should be sown in the spring as soon as conrenient after the frost is ont of the ground, on land seeded down the preceding antumu, probably, rather than sooner, in the autumn, as the winter is often too severe for tho tender roots."

A farmer of Worcester" county, says: "On moist land I prefer to turn over the green sward after haying, with a Michigan 
plough, and seed in August, after spreading on a coat of manure to give the grass an early start." A farmer of Franklin county, writes: "I consider the month of August as the best time to seed down land for mowing, with the exeeption of clover, and that I sow early in spring." Another from Hampden: "I think August or the early part of September is the best time to seed down grass land, as in the fall of the year it will get root and not be burned up by the sun, as it would be in spring." Another says: "I sow from the middle of August to the middle of september. If sown in spring with oats or other grain, the young grass is liable to bo summer-killed, either choked by the ranker growth of the grain, or scorched by the hot sun when the grain is taken off. If sown in spring without grain there is one season lost."

A farmer on the Connecticut River states, that "If the season is not too dry, August is a good month to seed for mowing. Have had very good success in seeding with turnips, or grass seed alone, in Aligust or September, to mow the next year; but the usual practice here is to seed with wheat or rye in September or October. Some seed in spring with oats, but generally it does not do well. Clover is more often sown in the spring, because it winter-kills." Another, writing from the northern part of Worcester county, says: "There is a difference of opinion among farmers in this region on this subject; some prefer to sow the grass seed with the spring grain in May, while others prefer to sow in Angust. The latter, no doubt, is the best practice, if the ground is sufficiently moist."

$A$ rery suecessful farmer of Berkshire, advises, "Angust or September. I have sown in the month of Oetober with good success. Seed sown in August obtains more root than when sown later, and consequently, is not as liable to winter-kill. It also starts earlier the succeeding spring, thereby keeping down the weeds. Much of our moist meadow lands, - too wet for hoed crops, and producing but light crops of grass, and that of an inferior quality, - may be made to produce well by ploughing and seeding. Let them be ploughed deep in August or September, the surface well-harrowed and covered with a light coat of compost, ashes or barnyard manure, and seeded, and the next year the crop will repay all expense." But on the other hand, a practical farmer on the island of Martha's Vine- 
yard, Duke's county, says: "I prefer secding down land designed for mowing, in April, for the reason that if sown in IIarch the ground becomes so compact from the eflects of heary rains that the seed does not come up well, and if sown in August or September the grass does not attain that degree of maturity to enable it to withstand the frequent freezing and thawing of the suceeding winter. We usually have but little snow to protect the young grass on this island. The oljection to sowing grass seed after English harvest will not probably apply to those places where the winters are less changeable."

Another says: "I have sown grass seed in the montlis of March, April, May, August, September and Oetober. On a rich, compact, retentive soil, seed has done well sown in April or May, but I prefer to seed my land of any description in August, or on a light snow in March. My reason is, that when I have secded my ground in the spring I hare sown rye or oats with the grass seed generally; if not, a crop of wecds would come up and usurp the place of the grasses and ehoke them out, and a hot and dry July and August would exterminate what eseaped the oats and weeds."

Thus, the opinions and practice of farmers is divided on this question, each one being influenced in part by the character of his land and his crops. But it will be found that no season is withont its exposure to loss, for if we sow in autumn and have an open and severe winter with frequent changes from comparatively warm and thawing weather to excessive cold, the young grass will be likely to suffer, while if we sow in spring with some kind of grain, as oats, barley or rye, and have a drought in spring or summer, as we generally do, the grass may be injured and may be entirely killed. No invariable rule for all soils and seasons can be given. But the weight of authority secms to fix upon early autumm as the best season to sow grass seed; sowing it alone without a grain crop, and the losses from proper sceding down, at that season are probably considerably less, in an average of years, than those which arise from spring sowing with grain.

But whaterer time may be chosen for sowing, it is very important that the seed bed should have been thoronghly tilled and properly prepared and manured. But instances hare fallon under my immediate observation where land which had become 
"lide-bound" and worn out, producing but a light crop of grass, was very much benefited by being tumed orer in September and haring a dressing of compost harrowed in, grass seed being then sown alone. The erop cren of the next year was much greater than that of previous years and nearly paid for the labor of plonghing and seeding by its increase.

No rule in regard to the time of seeding down land, which should be found to work best in one latitude, would necessarily apply in a different climate, and under different cireumstanees.

After having determined upon the time of sowing, the next question in the farmer's mind is as to the

\section{SELECTION OF SEED.}

In general, too little attention is paid to the selection of seeds, not only of the grasses, but of other cultivated plants. The firmer camnot be sure that he has good seed unless he raises it for himself or uses that raised in his neighborhood. He too often takes that which has passed througl sereral hands, and whose origin he camnot trace. Bad or old seed may thus lue bought, in the belief that it is good and new, and the seller limself may not know any thing to the contrary. The buyer, in such cases, often introduces weeds which are rery difficult to eradicate. The temptation to mix seeds left ored from previous years with newer seed, is rery great, and there can be no doubt that it is often done on a large seale. In such cases the buyer has no remedy. He camnot return the worthless article, and the repayment of the purchase money, eren if he could enforee it, would be but poor compensation for the loss of a crop. The seeds of some plants retain their vitality much longer than others. Those of the turnip, for instance, will germinate as well, or nearly as well, at the age of four or five years as when only one or two years old. But the seeds of most of the grases are of rery little value when they lave been kept two or three years, and lience the importance of procuring new and fresh seeds, and guarding against any mixture of the old and worthless with the new, as carefully as possible.

It is easy to tell whether the germinative power of grass or any other seed still remains, by the following simple method, 
and if the buyer should be willing to try it, he might purchase only a small quantity at first, and afterwards obtain his full supply with more confidence if the trial showed it to be good. Take two pieces of thick cloth, moisten thein with water and place them one upon the other in the bottom of a saucer. Place any number of seeds which it is desired to try, upon the cloth, spreading thin, so as not to allow them to cover or touch each other. Cover them orer with a third piece of cloth similar to the others and moistened in the same manner. Then place the saucer in a moderately warm place. Sufficient water must be turned on from time to time to lieep the three thicknesses of cloth moist, but great care must be taken not to use too much water, as this would destroy the seed. There should be only enongh to moisten the cloths, and not enough to allow any to stand in the sancer. Danger from this source may be aroided in a great measure, howerer, by tipping up the saucer so as to permit any superfluous water in the saucer to drain off. The cloth used for corering may be gently raised each day to wateh the progress of the swelling or the moulding of the seeds. The good seed will be found to swell gradually, while the old or poor seed, which has lost its germinating power, will becomo mouldy in a very few days. In this way, also, any one can judge whether old seed is mixed with new. The latter will germinate much more quickly than the former. He can judge, besides, of the quantity which he must sow, since he can tell whether a half, or three-fourths, or the whole will be likely to germinate, and can regulate his sowing accordingly. The seeds of the clovers, if they are new and fresh, will show their germs on the third or fourth day; other seeds will take a little longer, but till they become coated with mould there is hope of their germinating. As soon as the mould appears it is decisive, and the seed that moulds is worthless.

\section{MIXTURES OF GRASS SEED.}

It is difficult to overestimate the importance to the farmer of a good selection and proper mixture of grass seeds fur the rarious purposes of cultivation, for mowing, for soiling, for permanent pasturage, or for an alteruate crop. 
Doubtless the rarieties of seed nsually sown in this State, consisting almost exclusively of Timothy and redtop, with a mixture of red elover, are among the best for our purposes, and their cxelusive use is, in a measure, sanctioned by the experience and practice of our best farmers; yet, it would seem very strange indeed, if this vast family of plants, consisting of thousands of species and varietics, and occupying, as already intinated, nearly a sixth part of the whole vegetable kingdom, could furnish no more than two or three truly valuable species.

When we consider also, that some species are best adapted to one locality, and other's to another, some reaching their fullest and most perfect development on clay soils and some on lighter loams and sands, we camnot but wonder that the practice of sowing only Timothy and redtop on nearly all soils, clays, loams and sands indiscriminately, both on high and low land, should have become so prevalent. It is equally remarkable that while but very few of our grasses, and these for the most part species peculiar to sterile soils, flourish alone, but nearly all do best with a mixture of several species, it should so constantly have been thought judicious to attempt to grow only two prominent species together with merely an oceasional addition of an annual or a biennial clover, which soon dies out. When this course is pursued, unless the soil is rich and in good heart, the grass is likely to grow thin and far between, produeing lut half or two-thirds of a crop, whereas the addition in the mixture of a larger number of species, would have seeured a heavier burden of a better quality. These considerations, it seems to me, indicate the true direction in which the farmer who wishes to "make two spires of grass grow where one grew before" withont imporerishing the soil, should turn lis attention.

I loold this proposition to he indisputable, that any soil will yicld a larger and more nutritions crop if sown with several kinds of nutritious grasses, than when sown with only one or two species. Indecd, it is a fact well established by careful experiment, that a mixture of only two or three species of grases and clover, will produce a less amount of lay than cun be obtaincel by sowing a larger number of species together. There may be some exceptions to this rule, as in cases where the yield of Timothy and redtop, owing to the peculiar fitness 
of the soil for these grasses, is as great as can stand on the ground corered by them.

But it is nererthcless true, that if we sow but one kind of grass, howerer abundantly the sced may be scattered, or on whaterer soil it may be, or under howerer farorable influcnees, yet only a part of the plants will flourish; racant spaces will occur throughout the piece which will be filled up after a time by grasses of an inferior quality, weeds or mosses. This is the case in some degree also, where only two, or a small number of species arc sown; while if a mixture made up of a larger number of kinds of seed is used, the plants will corer the entire surface and produce a far.lotter quality of herloage.

In sowing such a mixture of several different species, we do but follow nature, who after all, will gencrally be found to be the best teacher, for wherever we cast our eyes over an old, rich, permanent pasture, we ordinarily see from fifteen to twenty species of grass or forage plants growing in social profusion. If the soil be very poor, as a cold, hard clay, or a barren sand, perhaps two or three varieties will suffice, but on good soils a larger number will be found to be far more profitable. Especially is this the case where the land is to be left in grass for some years and erentually be pastured, as is frequently done in New Fngland, for it is then desirable to hare grasses that reach their maturity at different times, as a constant succession of good feed throughout the season may thus more surcly be obtained. It is well known that there is no month of spring or summer in which some one of the grasses does not attain to its perfection, if we except the month of March. For goed soils, eight or ten species of the grasses or six or eight of the grasses proper and one or more of other herbage plants would probably be found to be profitable.

I am aware that the prevailing practice is decidedly against the use of any thing but Timothy, redtop and clover, and that very large crops of these grasses are often raised, but it is nerertheless true that we obtain on an average less than a ton to the acre, while with the same culture and a larger number of species we ought to get double that quantity.

Before proceeding to consider the proportions in which the different species should be mixed, it may be well to refer to the mode generally adopted for estimating the quantities of seeds 
their relative weight. And I may remark here that the prevailing practice of buying and sowing grass sceds by measure rather than by weight, secms injudicious to say the least. It is well known that old or poor seed weighs less than that which is fresh and new. Now if a farmer buys by weight, even if he does get an old or inferior quality of seed, he gets a much larger number of seeds, and this larger quantity of seed which he receires for his money, may make up for the inferior quality, and lie will have a larger number of seeds capable of germination than he would have if he bought by measure. It is to be regretted that it has become so nearly unirersal to purchase by measure, though as this course is for the seller's adrantage, it may be difficult to change the custom.

The following table, containing the weight per bushel of the seeds of the most important agricultural grasses, has been prepared chicfly from a raluable treatise on the grasses by the Mfessis. Lawson, of Edinburgh, who hare paid much attention to this subject, and whose experience and observation in the practical eulture of the grasses. has probably been larger and more extensive than those of any other seedsmen.

This table will be found to be exceedingly valuable for reference.

Column 1 contains the common names of the grasses.

Column 2, the average number of pounds in a bushel of the sceds.

Column 3, the average number of secds in an onince.

Column 4 shows the depth of soil in inches and fractions of an inch at which the greatest number of seeds germinate.

Colimn 5 shows the depth of soil in inches and fractions of an inch at which only one-half the seeds germinated.

Column 6 shows the least depth of soil in inches or fractions of an inch at which none of the seeds germinated.

Column 7 shows the arerage perecntage of loss in the weight of the grass in making into hay, when cut in the time of flowering.

The weight of seeds varies, of course, somewhat, from that stated in the above table, according to their quality. Those given in the table are the arerage weights of good, merchantable seed. In some States, as in Wisconsin, for instance, the legal weight of Timothy seed is forty-six pounds to the bushel. The weight of a bushel will depend in part, also, upon the 
thoroughness with which it is cleaned. The seeds of the different varieties of rye grass differ in weight, rarying from twenty to thirty pounds per busliel; but the average is about twentysix pounds.

Taine XIV. Weight of Grass Secds, and depth of Covering.

\begin{tabular}{|c|c|c|c|c|c|c|c|c|c|}
\hline & 1. & & & 2. & 3. & 4. & 5. & 6. & 7. \\
\hline Whitetop, . & . & . & . & 13 & 500,000 & 0 to $\frac{1}{4}$ & $\frac{1}{2}$ to $\frac{3}{4}$ & 1 & .65 \\
\hline Redtop, & - & . & - & 12 & $4 \pm 5,000$ & - & - & - & .63 \\
\hline Lassoek Grass, . & . & . & . & 14 & 132,000 & 0 to $\frac{1}{2}$ & $\frac{3}{4}$ to 1 & 21 & .65 \\
\hline Merdorv Foxtail, & & . & . & 5 & 76,000 & 0 to $\frac{1}{2}$ & 1 to 14 & $2 \frac{1}{6}$ & .57 \\
\hline Sweet-scented Vernal, & & . & . & 6 & 71,000 & 0 to $\frac{1}{2}$ & 1 to $1 \frac{1}{4}$ & 2 & .45 \\
\hline Tsull Oat Grass, & ${ }^{\circ}$ & . & . & 7 & 21,000 & $\frac{1}{2}$ to $\frac{3}{4}$ & $1_{2}^{1}$ to $1_{4}^{3}$ & 4 & - \\
\hline Stender Wheat Grass, & . & . & 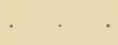 & 10 & 15,500 & 0 to $\frac{1}{4}$ & $\frac{1}{2}$ to $\frac{3}{4}$ & 2 & - \\
\hline Crested Dor's-tail, & . & . & . & 26 & $2 S, 000$ & - & - & - & - \\
\hline Orchard Grass, . & . & . & . & 12 & 40,000 & 0 to $\frac{1}{5}$ & $\frac{3}{4}$ to 1 & $2 \frac{1}{4}$ & .29 \\
\hline Ilard Feseue, & . & . & . & 10 & $39,0<0$ & 0 to 1 & $\frac{3}{4}$ to 1 & $2 f$ & - \\
\hline Tall Feseue, & . & . & . & 14 & 20,500 & 0 to $\frac{1}{4}$ & 1 to $1 \frac{1}{4}$ & $2_{4}^{3}$ & .52 \\
\hline Sheep is Fescue, . & . & . & . & 14 & 64,000 & 0 to & $\frac{3}{4}$ to 1 & 2 & .65 \\
\hline JIeadon Fescue, . & . & . & . & 14 & 26,000 & 0 to $\frac{1}{3}$ & $\frac{3}{4}$ to 1 & 21 & .60 \\
\hline Slender, or Spiked Fes & escue, . & & . & 15 & 24,700 & - & - & - & - \\
\hline Red Fescue, & . & . & . & 10 & 39,000 & - & - & - & - \\
\hline Jiced Jeadow Crass, & . & . & . & 13 & 58,000 & $\frac{1}{4}$ to $\frac{1}{2}$ & 3 to 1 & $2 ?$ & .30 \\
\hline Common Manua Gras & & . & . & 15 & 33,000 & - & - & - & .35 \\
\hline Meadow Soft Grass, & . & . & . & $i$ & 95,000 & $\frac{1}{4}$ to $\frac{1}{2}$ & 3 to 1 & $2 \frac{1}{2}$ & .73 \\
\hline 1talian Rye Grass, & . & . & . & 15 & 27,000 & 0 to $\frac{1}{4}$ & 1 to $1 \frac{1}{4}$ & $3 \frac{1}{4}$ & - \\
\hline Perential Rye Grass, & , . & . & . & 18 to 30 & 15.000 & $\frac{1}{4}$ to $\frac{1}{2}$ & $1 \frac{1}{2}$ to 13 & $3\}$ & .50 \\
\hline Millet Gruss, & . & . & . & 25 & 80,000 & $\frac{3}{4}$ to $\frac{1}{2}$ & 1 to $\frac{1}{4}$ & $2 ?$ & .33 \\
\hline Reed Canary Grass, & . & . & . & 48 & 42,000 & - & - & - & .32 \\
\hline Timothy, . . & . & 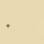 & . & 44 & 71,000 & 0 to $\frac{1}{4}$ & ${ }_{3}^{3}$ to 1 & 2 & .50 \\
\hline Wool Mleadow Grass, & & . & . & 15 & 173,009 & - & - & - & .31 \\
\hline June, or Spear Grass, & & · & . & 13 & 243,000 & - & - & - & .5 \\
\hline lioughi-stalked Meador & ow Gra. & ass, & . & 15 & 217,000 & 0 to $\frac{1}{4}$ & $\frac{1}{2}$ to $\quad 3$ & $1 !$ & .72 \\
\hline Feach Grass, & . & . & . & 15 & 10.000 & $\frac{1}{2}$ to 1 & $1_{2}^{1}$ to $1 \frac{3}{4}$ & 4 & - \\
\hline Yellow Oat Grass, & . & . & . & $5 !$ & 118,000 & 0 to $\frac{1}{4}$ & $\frac{3}{4}$ to 1 & 2 & - \\
\hline Heri Clover, . & . & . & . & 61 & 16,000 & 0 to $\frac{3}{2}$ & $1 \frac{1}{4}$ to $1 \frac{1}{2}$ & 2 & - \\
\hline Perennial Clover, & . & . & . & 64 & 16,000 & 0 to $\frac{1}{2}$ & 1 to 11 & 2 & - \\
\hline White Clover, & . & 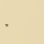 & . & 65 & 32,000 & 0 to $\frac{1}{4}$ & $\frac{1}{2}$ to $\frac{3}{4}$ & $1 \frac{1}{2}$ & - \\
\hline Lucerne, . & . & & . & 60 & 12,600 & - & - & - & - \\
\hline Saitroin: & . & . & . & 26 & 1,280 & ${ }_{4}^{3}$ to 1 & 2 to $2 \frac{1}{4}$ & $4 !$ & - \\
\hline
\end{tabular}


The number of seeds of each species in a pound, may be found, of course, by multiplying the numbers in column three by sixteen, the number of ounces in a pound. It is obrions, howerer, that these numbers must rary, like the number of pounds in a bushel, for it is evident that the lighter the seed, the greater will be the number of seeds in a pound. The numbers stated are the arerage obtained by eareful and repeated trials.

The results obtained in columns $t, 5$ and 6 , were obtained by careful experiment, and will be found to be rery suggestive.

The fact that the soil used in the experiments to ascertain the proper depth of corering was kept moist during the process of germination, though freely exposed to the light, aceounts for the large number of seeds germinated without any covering whatever. In ordinary field culture some slight corering is desirable; but the figures in column 6 show the important fact that in our modes of sowing and corering there mist be a great loss of seed from burying too deep, though the depth should be gorerned somewhat by the nature of the soil, as its usual moisture or dryness.

I have already expressed my opinion that we limit our mixtures to too few species, thus failing to arrire at the most profitable results, and hare said that, in a piece of land seeded with one or two favorite grasses only; small racant spaces will be found, which, in the aggregate will diminish very considerably the yicld of an acre, cren though ther may be so small as not to be pereeired. It might be thought that this could be aroided by putting into the ground a rery large number of seeds. But a knowledge of the quantities of seed ordinarily used in this State for sowing, and an inquiry as to the number of plants necessary to corer the ground with a thick coating of grass, will show that this is not the ease. I have in my possession letters from some of the best farmers in Berkshire, Plymouth and other comnties of the Commonwealth, in which they state it to be the prevailing practice to sow a bushel of redtop, a half bushel of Timothy, and from four to six pounds of red elorer to the acre. Some of them rary the proportions a little, as by the use of one peck of Timothy and a larger quantity of clover, but the general practice is to use nearly the quantities stated, some eren using a considerable larger quantity. Now if we examine the table we shall find that in an ounce of redtop seed there 
are 425,000 grains. In a pound there are $6,800,000$ seeds; in a bushel, or twelre pounds, there are $81,600,000$ sceds. Now take only one peek of Timothy seed to mix with it. In an ounce of Timotlyy grass seed there are 74,000 grains. In a pound there are 1,204,000 grains. In eleren pounds, or a peck, there are 13,2t4,000 seeds, and if we take but four pounds of clorer, which is below the arerage quantity used, we shall find by the same process that we hare $1,02-1,000$ seeds. If now we add these sums together, we shall find that we have put upon the acre in less than $95,868,000$ seeds! This gives over 15 seeds to the square inch, or about 2,200 seeds to the square foot!

Again, one of the most intelligent farmers of Middlesex connty, a practical man, uses fire pecks of redtop and twelvo quarts of Timothy seed per acre, for mowing lands, and an addition of fire pounds of white clover for pastures, making no less than $124,124,000$ seeds per acre. There must be, eridently, an enormous waste of seed, or an extensire destruction of plants, for if we take nature for our guide, we shall not find any thing like that amount of plants on an inch or a foot of our grass lands. Now let us see from a very careful trial how many plants and how many species are to be found in a square foot.

TABLE XV. Average number of Plants and Species to the square foot of Sward.

\begin{tabular}{|c|c|c|c|c|}
\hline CHARACTER OF THE TURF. & 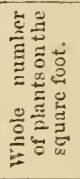 & 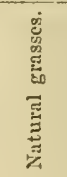 & 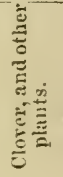 & 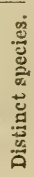 \\
\hline $\begin{array}{l}\text { 1. A fquare foot taken from the richest natural pasture, eapable of } \\
\text { fittening ome large ox or three sheep to the nere, was found to } \\
\text { contain. }\end{array}$ & 1,000 & 910 & 60 & 20 \\
\hline $\begin{array}{l}\text { 2. Rich old pasture, capable of fatteuing one large ox and three } \\
\text { sheep, jer aere, }\end{array}$ & 1,090 & 1,032 & 58 & - \\
\hline 3. Another old pasture contained & 910 & 880 & 30 & 12 \\
\hline 4. An old pasture of a damp, moist, and mossy surfice, . & 631 & 510 & 124 & 8 \\
\hline $\begin{array}{l}\text { 5. A good pasture, two years old, laid down to rye grass and white } \\
\text { clorer, }\end{array}$ & 470 & 452 & 18 & 2 \\
\hline $\begin{array}{l}\text { 6. A sol of narrow-leaved meadow grass, (poa angustifolia,) six years } \\
\text { old, }\end{array}$ & 192 & - & - & 1 \\
\hline T. A sod of meadow foxtail by itself, six years old, & 80 & - & - & 1 \\
\hline 8. Ityc Grass by itself, same age, . & 75 & - & - & 1 \\
\hline 9. Neadow, irrigated and carefully managed, & 1,798 & 1,702 & 90 & - \\
\hline
\end{tabular}


These plants in each instance were counted with the utmost care by a farmer now liring in this State, then in the employ of Mr. Sinclair, and the correctness of his results may be relied on.

Now it is a well known fact that the sward of a rich old pasture is closely packed, filled up, or interworen with plants and no racant spaces occur. Tet, in a closely crowded turf of such a pasture, only one thousand distinctly rooted plants were found on a square foot, and these were made up of twenty different species. The soil should be supplied with a proper number of plants, else a loss of labor, time and space will be incurred; but howerer hearily seeded a piece may be with one or two farorite grasses, small racant spaces will occur, which, though they may not seem important in themselves, when taken in the aggregate, will be found to diminish very considerably the yield of an acre, even if they are so small as not to be pereeired. And undonbtedly some allowance should be made for the seeds and young plants destroyed by insects, birds and varions accidental causes; but cren after all deductions for these, we sec that in this State, at least, there is no deficiency in the quantities of seed used, and the imperfectly covered ground camnot be explained in this way.

The abore table is also important as an illustration of the truth of my general proposition. It shows that in those pastures where fer species were found together, whether in old, natural pastures or in artificial meadows, the number of plants on a giren space was proportionably small. Sinclair, too, who lad observed carefully and extensively, writes on this point in regard to the practice of oversecding, as follows: "When an excess of grass seed is sown, the seeds, in general, all regetate, but the plants make little, if any progress, until from the want of nourishment to the roots, and the confined space for the growth of the foliage, a certain number decay, and give the requisite room to the proper number of plants; and that will be according as there are a greater or less varicty of different species of grasses combined in the sward."

It is proper to make some allowance for bad seed, it is true, but our practice is defective and uneconomical. In the examination of the rich and productire pasture turf, from twelve to twenty species were found closely mixed together, and there were six or seren plants to the square inch. We sow seed 
enough, frequently, for fifteen plants to the inch, but rarely obtain abore two or three, and very frequently even less than that.

The difficulty of procuring the seed, and its expense, hare been the strongest objections to the use of many species. A demand for these species, howerer, would soon remore this difficulty, and varieties would be kept for sale in Boston at a reasonable price. When it is considered that the additional expense of sowing a ficld or permanent pastnre witl a greater number of species will be, comparatirely, very small, while the additional yicld will be proportionably large,-if the result is as farorable as the opinion of many who liave made the trial would lead us to expect,-every farmer must admit that it is for his interest to try the experiment, on a small scale, at least.

It will be evident, after a moment's reflection, that very different mixtures, both as regards the species and the relatire quantities of each, will be desirable for different soils; that dissimilar mixtures would be required for alternate cropping or laying down land for only a year or two, and for permanent pasture. In our pratice it is most common to seed down for some years, and not unfrequently this is done with the design of cutting the grass for hay for a few years and then pasturing the ficld, in which case our seeding down assumes the character of laying down for pormanent pasturage. Equally good, but very different mixtures might be made, also, for the same soils by different individuals who had difierent objects in riew, some desiring a very early erop, some wishing to select species which resist the access of profitless weeds, and others to enltivate those varieties which exhaust the soil the least. Each of these mixtures may be best adapted to the specifie object of the farmer who makes it, and if composed of a sufficient number of species, may be good and truly economical.

The practice with many in New England has already been alluded to as consisting usually of one bushel, or twelre pounds of redtop, a lialf a bushel, or twenty-two pounds of Timothy, and from four to six or eiglit pounds of closer. The practice of good farmers raries but little from this mixture.

Thie following tables are recommended by Lawson \& Son, of Edinburgh. Only a few of the mixtures have been sufficiently tried.in this country, and they may need some modifieation to meet the exigencies of our severe droughts. It may be proper 
to remark here that the climate of Scotland, in some respects, does not differ much from our own. The latitude of Edinburgh is $55^{\circ} 57^{\prime}$, that of Boston, $42^{\circ} 21^{\prime}$; while the mean ammual temperature of the former is $47^{\circ} .1$ Fahr., that of the latter, $48^{\circ} .9$, showing a very slight difference. But our summers are hotter, and we are annually liable to the most serere and parching dronghts, such as are not often felt in Scotland.

The quantities are stated in pounds. If any one is desirous of reducing them to measures he may easily do so by the use of table XIV., which gives the weight per bushel of each species.

Table rvi. For Permanent Pasture.

\begin{tabular}{|c|c|c|c|c|c|c|c|c|}
\hline Meadow Foxtail, . & . & . & . & . & . & . & . & 2 pounds. \\
\hline Orchard Grass, & . & - & - & . & . & . & . & 6 \\
\hline Hard Fescue, & . & . & . & - & . & - & . & 2 \\
\hline Tall Fescue, . & . & . & - & . & . & . & . & 2 \\
\hline Meadow Fescue, & . & . & . & . & . & . & . & 2 \\
\hline Italian Rye Grass, & . & - & - & • & $\cdot$ & $\cdot$ & $\cdot$ & 6 \\
\hline Perennial Rye Grass, & . & . & - & - & . & - & . & 6 \\
\hline Timotly, . & . & . & . & . & - & - & . & 4 \\
\hline Redtop, . & . & - & - & - & - & - & . & 2 \\
\hline Roumh-stalked Meadow & Grass, & - & - & - & - & - & . & 3 \\
\hline Red Clorer, . & . & - & - & - & - & - & . & 2 \\
\hline Perennial Clover, . & . & . & - & - & - & - & . & 3 \\
\hline White Clover, & . & . & . & . & . & . & . & $5-45$ \\
\hline
\end{tabular}

Here we hare a considerable number of species, and according to table XIV., over $15,500,000$ sceds. Thus, though we use less than half as many sceds as our farmers generally do, we still allow more than seven seeds to the square inch, or over 1,000 seeds to the square foot, a number larger than the number of plants found in the rich and closely woven sward of an old pasture, as secn in table XV. These, it will be seen, even if we make a large allowance for bad seeds, will produce as many 
plants as will grow well, while we still have by far the largest number of stalks of redtop from no less than $3,600,000$ seeds, though the weight of the redtop seed is but two pounds. This mixture is designed for one acre sown without grain in the fall.

A mixture like the above would answer rery well, and is less expensire than the following, though it is probable that the greater original outlay for the seeds recommended in the following talule will be more than returned in the additional yield.

TABLe XVII. For Permancht Pasture.

\begin{tabular}{|c|c|c|c|c|c|c|c|c|}
\hline Meadow Foxtail, . & . & . & . & - & - & . & . & 2 pounds. \\
\hline Orchard Grass, & - & • & - & . & • & . & . & 4 \\
\hline IIard Fescue, & . & & ${ }^{\circ}$ & - & • & . & • & 2 \\
\hline Tall Fescue, . & . & $\cdot$ & $\cdot$ & . & . & - & • & 2 \\
\hline Meadow Fescue, & . & ${ }^{\circ}$ & . & . & • & - & • & 2 \\
\hline Redtop, . . & . & . & . & . & • & - & . & 2 \\
\hline June Grass, . & . & $\theta^{\circ}$ & • & • & • & - & $\cdot$ & 2 \\
\hline Italian Rye Grass, & . & . & . & . & • & • & • & 6 \\
\hline Perennial Rye Grass, & . & • & . & • & • & - & • & 8 \\
\hline 'Timothy, . & . & ${ }^{\circ}$ & ${ }^{\circ}$ & $\cdot$ & • & - & • & 3 \\
\hline Wool Meadow Grass, & . & - & - & . & . & - & • & 2 \\
\hline Rough-stalked Meadow & Grass, & . & $\cdot$ & . & . & - & $\cdot$ & 2 \\
\hline Yellow Oat Grass, & - & & & & ${ }^{\circ}$ & • & • & 1 \\
\hline Perennial Clover, . & . & $\cdot$ & & . & . & - & • & 2 \\
\hline White Clover, & . & . & & • & • & - & • & $5-45$ \\
\hline
\end{tabular}

If the cultivator desires to produce a close, matted sward as soon as possible, 110 broad-leaved clover should be used, and the above mixture will be quite sufficient without the perennial clover.

If the object be to make a permanent lawn, as is frequently desirable around or in sight of the farm house, something like the following mixture will be found to be on the whole the best. 
Tame Xirir. Permanent Lawn Grasses in Mixture.

Mearlow Foxtail,

Sivect-sented rernal Ginse,

Relto

ITarl Fescue, .

Shcep's Fescuc,

Mrorilow Fescue,

Rerl Fescue,

Itulian Piye Grass,

Perennial Rye Grass,

'Timothy, .

June, or Common Spear Grass,

l:ough-stalked Mcadow Grass,

Yellow Oat Grass,

Peremial Clover,

Iied Clorer,

White Clover,

\begin{tabular}{cccc|c}
$\cdot$ & $\cdot$ & $\cdot$ & $\cdot$ & 1 pound. \\
$\cdot$ & - & $\cdot$ & $\cdot$ & 1 \\
$\cdot$ & $\cdot$ & $\cdot$ & $\cdot$ & 2 \\
& & & & \\
3
\end{tabular}


Tabie XIX. Mixture for Mowing in the Rotation.

\begin{tabular}{|c|c|c|c|c|c|c|c|c|c|}
\hline \multicolumn{7}{|c|}{ NAME OF GRASS. } & \multirow[t]{2}{*}{ 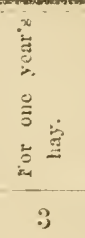 } & \multirow{2}{*}{ 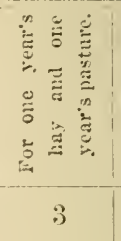 } & \multirow{2}{*}{ 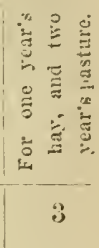 } \\
\hline Redtop, . & . & . & . & . & . & - & & & \\
\hline Italian Rye Grass, & . & . & . & . & . & & 6 & 6 & 6 \\
\hline Perennial Rye Gr & & . & . & . & . & . & 3 & 3 & $\ddot{3}$ \\
\hline Orchard Grass, & . & . & . & . & . & . & 4 & 6 & 6 \\
\hline Timothy, . & - & . & . & . & . & . & 11 & 9 & 9 \\
\hline Red Clover, & . & . & . & . & . & . & 8 & 4 & 2 \\
\hline Perennial Clover, & . & . & . & . & . & . & - & 2 & 4 \\
\hline \multirow[t]{2}{*}{ White Clover, . } & . & . & . & - & . & . & 2 & 4 & 4 \\
\hline & & & & & & & 37 & 37 & 37 \\
\hline
\end{tabular}

Table XX. Permanent Lawn Pastures.

\begin{tabular}{|c|c|c|c|c|c|c|c|c|}
\hline Meadow Foxtail, & . $\cdot$ & . & • & • & • & . & . & 1 pound. \\
\hline Sweet-scented Vernal & Grass, & . & . & . & . & . & . & 1 \\
\hline Orchard Grass, & . & . & . & . & . & . & . & 3 \\
\hline Irard Fescue, . & - & . & . & - & . & . & - & 2 \\
\hline Sheep's Fescue, & . & . & - & . & . & . & - & 2 \\
\hline Meadow Feseue, & . & . & - & • & . & . & . & 2 \\
\hline Italian Rye Grass, . & . & . & . & - & . & . & . & 6 \\
\hline Perennial Rye Grass, & . & . & . & - & - & . & . & 4 \\
\hline Timothy, & . & . & - & - & - & . & . & 7 \\
\hline Redtop, . & - & . & . & . & . & . & • & 8 \\
\hline Rough-stalked Meado & w Grass, & - & - & - & - & - & • & 3 \\
\hline Yellow Oat Grass, . & . & . & • & - & . & . & . & 1 \\
\hline Ried Clover, & . & . & • & • & - & • & • & 2 \\
\hline Perennial Red Clover & . & . & - & • & - & • & . & 2 \\
\hline IVhite Clover, & . & . & - & . & . & - & • & $4-43$ \\
\hline
\end{tabular}


Table XXI. Fine Lawns frequently Mown.

\begin{tabular}{|c|c|c|c|c|c|c|c|c|}
\hline Crested Dor's-tail, . & . & - & - & - & . & • & & 10 pounds. \\
\hline IIard Fescue, . & . & . & - & · & - & - & . & 4 \\
\hline Slender-leaf Sheep's F & escue, & - & . & . & . & . & - & 2 \\
\hline Perennial Rye Grass, & . & . & . & . & . & . & . & 10 \\
\hline Wood Meadow Grass, & . & . & . & . & . & . & . & 2 \\
\hline Rough-stalked Meadon & Grass, & & - & - & . & . & - & 1 \\
\hline Yellow Oat Grass, . & . & . & . & - & . & . & . & 1 \\
\hline June Grass, . & . & . & . & . & . & . & . & 8 \\
\hline White Clover, & - & . & . & & . & & & $8-46$ \\
\hline
\end{tabular}

TABLE XXII. Hay and Pasture in Orchards and Shaded Places.

\begin{tabular}{|c|c|c|c|c|c|c|c|c|}
\hline Sweet-scented Vernal & Grass, & . & . & . & . & . & . & 1 pound. \\
\hline Orchard Grass, & . & . & . & . & . & . & . & 6 \\
\hline Hard Fescue, . & . & . $\quad$. & . & . & . & . & . & 2 \\
\hline Tall Fescue, . & . & . & . & - & - & - & - & 2 \\
\hline Italian Rye Grass, . & . & . & . & . & . & . & . & 4 \\
\hline Perennial Rye Grass, & . & . & . & . & . & . & . & 4 \\
\hline Timothỵ, & . & - & . & . & . & . & . & 6 \\
\hline Wood Meadow Grass, & . & . & . & . & . & . & . & 4 \\
\hline Roughh-stalked Meadow & Gras :, & . & . & . & . & . & . & 2 \\
\hline June Grass, . ' . & . & . & . & . & . & . & . & 4 \\
\hline Perennial Red Clover, & . & . & . & . & • & . & . & 3 \\
\hline White Clover, & . & . & . & . & . & . & & $4-42$ \\
\hline
\end{tabular}

For rery sandy, dry pastures and heathy moors, the following. [Table XXIII.]

For reclaimed swamps, after draining, designed to be kept in grass for liay, the mixture stated in table XXIV. is good. 
TABLE XXIII. Mixture for Mowing on Light Sands.

Tall Meadow Oat Grass,

Orchard Grass,

Hard Fescne,

Meadow Sof Grass,

Italian Rye Grass,

Perennial Tiye Grass,

Timotly,

Perennial Red Clover,

White Clorer, 3 pounds. 4 6 3 4 3 3 $4-10$

TABI. IXIV. Mixture for Reclained Fealy Lands.

Whitetop, variety called Fiorin, 2 pounds.

Redtop,

Meadow Foxtail,

Fowl Meadow,

Italian Rye Grass,

Perennial Rye Grass,

Reed Canary Grass,

Timothy, 2 2 4

Rough-stalked Meadow Grass, . . . . . . . 3

White Clover,

$1-10$

If a leclaimed meadow is subject to occasional orerflows of fresh water, the addition of two or three pounds of the numna grass, (slyceria flutans,) if it can be had, will be an improvement. On such soils Fiorin, a variety of whitetop, does remarkably well, and the rough stalked meadow is indispensable. A mixture especially adapted to such situations would be something like the following:- 
TAli: XXV. Marshy Grounds, liable to be occasionally oicrflowed with fiesh water.

\begin{tabular}{|c|c|c|c|c|c|c|c|c|}
\hline \multicolumn{7}{|c|}{ XAME OF ciRASs. } & l'raty suils. & Alluvial Suila. \\
\hline Fionin, . & . & . & . & . & . & - & 4 pounds. & 3 pounds. \\
\hline 'Wall Fescue, & . & . & . & . & . & . & 3 & 4. \\
\hline Manna Grass, & - & . & - & - & - & - & 5 & 5 \\
\hline Iieed Canary & Grass, & . & . & - & . & - & 3 & 4 \\
\hline 'Timothy, & . & . & - & . & . & . & 1 & 4 \\
\hline Rough-stalked & Meadow & Grass, & . & . & . & . & 4 & 3 \\
\hline Fowl Meadow & Griass, & . & . & - & . & . & 6 & 5 \\
\hline White Clover, & . & . & - & - & - & . & $3-32$ & $4-32$ \\
\hline
\end{tabular}

If it be desired to corer rocky and gravelly hills and soils of a rery poor quality with grass, the mixture in the following table will be most serviceable.

Taвle XXvi. Mirture for Rocliy Hills.

\begin{tabular}{|c|c|c|c|c|c|c|c|c|}
\hline Recitop, . . & .. & . & . & . & . & . & . & 2 pounds \\
\hline Tall Oat, & . & . & . & . & . & . & . & 2 \\
\hline Crested Doges-tail, . & . & . & . & . & . & . & . & 3 \\
\hline Orchar ! Gras:, & . & . & . & - & . & . & . & 3 \\
\hline lied Fesene, . & . & . & . & . & . & . & . & 4 \\
\hline Mealow Soft Grass, & . & . & . & . & . & . & $\therefore$ & 2 \\
\hline Perennial liye Grass, & . & . & . & . & . & . & . & 6 \\
\hline 'Tinothy, & . & . & . & . & . & - & - & 6 \\
\hline Whod Meadow Grass, & . & . & . & . & . & . & . & 3 \\
\hline Common Spear Grass, & . & . & . & . & . & . & . & 2 \\
\hline liongh-stalked Meadow, & . & . & . & . & . & . & . & 2 \\
\hline IWhite Clover, & . & . & . & . & - & - & . & $8-43$ \\
\hline
\end{tabular}


If the soil be very dry, the wood meadow grass and the Timotlyy may be omitted from the above mixture, and a larger quantity of June grass used. The following mixture is well adapted to dry, grarelly soils, which are difficult to turf over.

\section{Table rivil. Mixture for Dry Gravels.}

\begin{tabular}{|c|c|c|c|c|c|c|c|c|c|}
\hline Redtop, . . . & . & . & . & . & . & . & . & . & 3 pounds. \\
\hline Tall Oat Grass, & . & . & . & . & . & . & . & . & 8 \\
\hline Red Fesine, . & . & . & . & - & . & . & . & - & 4 \\
\hline Meadow Soft Grass, & . & . & . & . & . & . & . & . & 4 \\
\hline Soft Brome Crrass, . & . & . & . & . & - & . & . & . & 4 \\
\hline Perennial Rye Grass, & . & . & . & . & . & . & . & . & 5 \\
\hline June Grass, . & . & . & . & . & - & . & . & . & 4 \\
\hline White Clover,. & . & . & . & . & . & . & . & . & $4-36$ \\
\hline
\end{tabular}

For protecting banks of ricers and streams from washing and wearing away, the reed canary grass and the reed meadow grass will be found rery effectual. For preventing the drifting of light sand, beach grass, (ammophila arundinacea,) is one of the best. It is extensirely used for this purpose at Provincetown and rarious other places along the coast. I have sown the seeds of other species in such situations, but know of none equal to beach grass for the purpose of fixing moring sands.

As already seen, the general practice in New England is in strong contrast with the foregoing tables of mixtures, for of the two hundred towns heard from, all appear to raise the same species, but no two recommend the same quantities for mixture, and not one reports the use of more than two species of grass mixed with one or sometimes two species of clorer, as at all comm $n$.

As examples of the general practice as reported to me, and with which I hare been familiar for many years, the following might be stated.

I. $\frac{1}{2}$ bushel (fs lbs.) redtop, 1 peck (11 liws.) Timothy, 5 lbs. red clover.

II. 1 I usinel (12 lbs.) rediop, 1 peck Timothy, 8 lbs. red elover.

III. $1 \frac{1}{2}$ bushels (1S lbs.) redtop, 4 qts. ( $5 \frac{1}{2} \mathrm{lbs}$.) Timothy, 3 lbs. red ciover. 
IV. 3 peeks (9 lbs.) redtop, 6 (quarts Timothy, 6 lbs. clover.

V. 1 bushel (12lbs.) redtop, 1 bushel ( 11 lbs.) Tim'y, 10 to 15 lbs. clorer.

VI. 1 peck (3 lbs.) redtop, 1 peck (11 lbs.) Timotlyy, 8 llus. clover.

VII. 4 quarts ( $1 \frac{1}{2}$ llbs.) redtop, 1 peek (11 lbs.) Timothy, 2 quarts red clover, 1 pint white clover.

VIII. 16 quarts, ( 6 lbs.) redtop, 12 q'ts (16 $\frac{1}{2}$ lbs.) Timothy, 6 lbs. clover.

IX. 12 quarts (16 $\frac{1}{2}$ lbs.) Timothy, 4 lbs. clover.

X. 1 bushel (12 lbs.) redtop, $\frac{1}{2}$ bushel (22 lbs.) Timothy, 10 lbs. clover.

XI. 1 peck redtop, 3 pecks 'Timotlly, 6 lbs. clover.

XII. 3 peeks redtop, 1 peek Timotlyy, 5 lbs. clover.

XIII. 1 bushel finetop, 1 peek Timothy, 8 lbs. clover.

XIV. 1 bushol redtop, 1 peck Timothy, 12 lbs. clover.

IV. 16 quarts redtop, 10 quarts Timothy, 6 lbs. clover.

XVI. 1 bushel redtop, $\frac{1}{2}$ bushel Timothy, 10 lbs. elover.

XVII. 5 peeks redtop, 青 bushel Timothy, 4 lbs. clorer.

XVIII. 1 buslıel redtop, 1 peck Timothy, 8 lbs. clover.

XIX. 1 peck redtop, 1 peck Timothy, $10 \mathrm{lbs}$. clover.

XX. 3 pecks redtop, $S$ to 10 quarts Timothy, 6 to $8 \mathrm{lbs}$. clorer.

These mixtures are sufficient to show the excecding dirersity in our practice.

A little attention to the weight of the different seeds recommended in the abore tables will explain why one particular quantity which may appear small at first sight, is sufficient in some cases, as it will show a rast difference in their weight; a givell number of pounds of some species containing many more secis, and therefore producing a far larger number of plants, than an equal weight of others.

There are few points in our practice, it secms to me, where greater improvements could be made than in the selection and mixture of our grass seeds. If the money which is now literally thrown away by over-sceding with one or two species were expended in procuring other species and improving our mixtures, there is but little doubt that the aggregate profit on our grass crop would be much greater than it now is.

Some maintain that one or two species are sufficient, because certain crasses are "natural," as they say, to their land, and come in of themselves. This may, in some cases, be true to some extent, for such grasses will come in, in time, but we are 
liable to lose sight of the fact that the loss of a full yicld, in the meantine, is often very serious.

But the inference which farmers draw from this fact is not a legitimate one, for they say that it prores that the grasses that come in "naturally," that is, the wild grasses, are best adapted to the soil, and will produce more largely than others in that locality. But this, if carried out to its natural consoquences, would lead to the conclusion that new species of plaints should never be introduced into any soil, because those best snited to it grow there "naturally" - a principle which no man will assert. On the contrary, one great object of all intelligent farming is to improve upon nature, and to increase the natural capacities both of the soil and of the plants which grow on it; and the introduction of now species and rarieties is one of the most effectual means of accomplishing this end. Particular species of plants do not always spring up in particular places because they are peculiarly adapted to the soil, but often from mere accident. Seeds are carried by the wind or by animals or birds, and being dropped, produce plants on the spot where they fall. These plants again produce seeds which fall and in their turn produce other plants. Thus a particular species of grass or any plant may be introduced into, and fixed in a locality where it has no special adaptation to the soil there, and the most common plants or varieties of plants will be most likely to spread in this way. Hence the mere fact that a certain species is very generally diffused in a certain district, does not by any means prove that it is better suited to the soil of that district than any other species, nor that it will be sure to come in if onitted in a mixture of grasses designed for such a locality.

As already said, the mixture of grass seeds in imitation of nature for the purpose of forming good permanent fields or pastures, is of comparatively modern origin. It was, for a long time after this practice commenced, thought to require a great while to form a thick and good sward or turf, by any artificial means. The use of a large and judicionsly selectod number of species, has been found to accomplish this object most quickly.

'Though I hare expressed myself with some dogree of confidence on this subject, I would still refer to the importance of careful experiment. The ontlay is small, when compared with the losses now sustained in over-secding with too fer 
species, and from small or medium crops; and the farmer can soon satisfy himself as to the profit of more attention to the mixtures of grasses.

\section{TIME TO CUT GRASS FOR HAY.}

Having earefully sclected and judicionsly mixed and sown his grass seed at a proper season, the farmer may confidently hope to have an abundant crop of grass the following year, when there will naturally arise one of the most important questions in the economy of the farm, and that is, when to cut grass to make into hay, or at what stage of its growth it is most valuable for that purpose. This is a point on which even experienced farmers differ, but the weight of authority will be found strongly for cutting at the time of flowering. Most jractical farmers, in answer to this question say that hay is swecter, and possesses more nutriment when cut in full blossom than at any other stage. One of the most intelligent farmers of Middlesex county says: "I prefer to cut grass when in blossom, because it will make more milk and more fat, and cattle prefer it to that standing later. It keeps them loose and healthy. I have no doubt hay of the same bulk weighs more if it stands in the field till the seed forms, and for this reason some who sell most of their hay let it stand." A farmer of Worcester county says: "When designed for milch cows, store, or fattening animals, I prefer to cut in the blossom, because it makes more milk, more growth and more beef. For working cattle and horses I cut about six days after the pollen has fallen, because it does not scour or loosen the animal so much as when eut in the blossom." A farmer of Hampshire county says: "Next to sweet, fresh grass, we think that rowen will make cows, working cattle or horses thrive better than any other feed, unless in the case of cattle hard at work. We conclude, therefore, that all hay is best cut early. Coarse liay will keep stock tolerably well, cut early, which if allowed to mature would not be eaten at all." A farmer of Hampden county says: "We cut after the blossoms begin to fall, and before they have all fallen. It has more substance and weight cut at that time than if eut sooner, more sweetness and juice than if cut later." A farmer of Berkshire county says: "Our rule is to cut hay in the blossom, as it is then in the best state for feeding, less woody and 
much sweeter than later, and leares the roots in better state for a second, or another annual crop." Another very intelligent, practical farmer says: "We cut in blossom, because it is then most palatable to stock. If allowed to stand much longer there is a draft upon the soil for the growth of the seed, which is not repaid by the additional value of the hay, if, indeed, it is increased in ralue at all. My opinion, derived from my own experience, is, that the grasses will sooner die out if allowed to stand later." A farmer who prefers to eut all other grasses when in blossom, says: "It will not do to eut blue joint or fowl meadow till some of the seeds fall, as it will soon run them out." An intelligent farmer of Norfolk county says: "When English grass is in full blossom it has all the good qualities it can have. From that time I think it loses in value in proportion to the time which it stands. Swale hay should be cut rather green. If fully ripe it is hard and dry." Another says: "We cut about the time the blossom falls. The grass is then at its full growth. If it stands much longer the leares begin to die at the bottom and the grass grows tough and hard, and I think the longer it stands the less it will weigh when dried. If it is cut much earlier it will shrink and dry up and does not seem to have so much nutriment in it, and I have noticed cattle will eat more in bulk than when ent at the right time." Another says: "The time of cutting depends rery much upon the use you wish to make of it. If for working oxen and loorses, I would let it stand till a little out of the blossom, but if to feed out to new milch cows in the winter, I would prefer to cut it very green. It is then worth for the making of milk in the winter, almost double that eut later." One other extract will suffice. A farmer of Middlesex county says: "I cut my red clorer before the heads begin to turn brown. When the clover is quite heary I cut it when only onc-half the heads have blossomed, because then eattle will eat all the stems. Clover is injured more by lialf when it stands long after blossoming than any other kind. I find my clover hay in the barn much heavier swlen cut quite early."

These extracts, taken at random from a large number of letters from practical farmers all orer the State, indicate rery clearly the prevailing practice. The replies from about one hiundred and fifty towns are, that farmers prefer to cut the 
principal grasses, Timothy and redtop, when in full blossom; red clorer when about half the heads are in blossom, and swale grass before it is ripe, and generally before blossoming, if possible, so as to prevent it from becoming hard and wiry.

This practice is unquestionably founded on a correct principle, the object of the farmer being to secure his hay so as to make it most like grass in its perfect condition. From principles stated in another place, it has been seen that the nutritire substances of grass are those, which are, for the most part, soluble in water, such as sugar, gluten, and other compounds. Now it is erident that if this is so, the grass should be cut at the time when it contains the largest amount of these principles. In its early stages of growth it contains a very large percentage of water. From its earliest growth the sugar and other soluble substances gradually increase till they reach their maximum percentage in the blossom, or when the seed is fully formed in the cell. From this period the saccharine matter constantly diminishes, and the woody fibre, perfectly insoluble in water, and immutritious, increases till after the secds have matured, when the plant begins to decay. Of course, if the plant is not cut in the flower, a great part of the nutriment of its stems and leares is wasted.

There are some exceptions to this rule in the natural grasses, as already seen in considering their nutritive qualities, and in the analyses at different periods of their growth. Thus, in case of the orchard grass, Sinclair found the mutritive matter at the time the seed was ripe and at the time of flowering, as seren to fire, and the stems of Timothy were found to contain more nutritive matter when the plant was ripe, than at the time of flowering, though it was found that the loss of aftermath which would have formed had the plant been cut in blossom, more than balanced the gain of nutritive matter in the ripening of the seed. Most of the grasses, too, make a greater quantity of hay when cut at the time of blossoming, though the crested dog's tail has been found to be an exception to this rule. Fowl meadow, also, contains an equal quantity of produce at the time of ripening the seed and at the time of blossoming, and the mutritive matter at both periods is about the same. It will be found in practice generally to be better to be a little too early than too late, for the gain is in two directions, in 
a greater nutritive sulustance at the time of blossoming, which is certainly a sufficient consideration of itself, and in the larger growth of the lattermath which will spring up on good land and in a good season.

We might also reason from analogy in other plants, for it is a well known fact that the best vegetable extracts for medicinal and other purposes, are procured from plants when in blossom. Prof. Kirtland, of Ohio, states that an observing, practical farmer of his neighborhood, after many careful observations on the growth of 'Timothy, has arrived at these propositions:-

1. That Timothy grass is a perennial plant, which renews itself by an annual formation of "bulbs," or perhaps, more correctly speaking, tubers, in which the ritality of the plant is concentrated during the winter. These form in whatever locality the plant is selected, without reference to dryness or moisture. From these proceed the stalks which support the leares and head, and from the same source spread out the numerous fibres forming the true roots.

2. To insure a perfect development of tubers, a certain amount of nutrition must be assimilated in the leaves, and returned to the base of the plant, through the stalk.

3. As soon as the process of nutrition is completed, it becomes manifest by the appearance of a state of desiecation, or dryness, always commencing at a point directly abore either the first or second joint of the stem near the crown of the tuber. From this point the desiccation gradually progresses upwards, and the last portion of the stalk that yields up its freshness is that adjoining the head. Coincident with the begiming of this process, is the full development of the seeds, and with its progress they mature. Its earliest appearance is eridence that both the tubers and seeds have received their requisite supplies of nutrition, and that neither the stalk nor the leaves are longer necessary to aid them in completing their maturity. A similar process occurs in the mion just above the crown of the bulb, indieating the maturity of that organ. Fig. 97 represents the bulb fully developed and mature, from which the stalk was cut, after the nutritive process was completed, above the point where drying or desiccation had begun.

4. If the stalk be cut from the tubers before this evidence of maturity has appeared, the necessary supplies of nutrition will 
be arrested, their proper growth will cease, and an effort will be made to repair the injury by sending out small, lateral tubers, from which weak and unhealthy stalks will procecd, at the expense of the original tubers. This is seen in Fig. 98. All will ultimately perish cither by the droughts of autumn or the cold of winter.

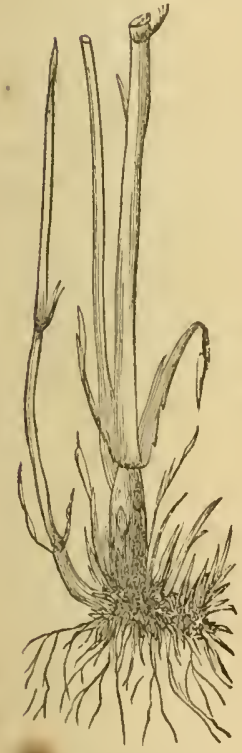

Fig. 93.

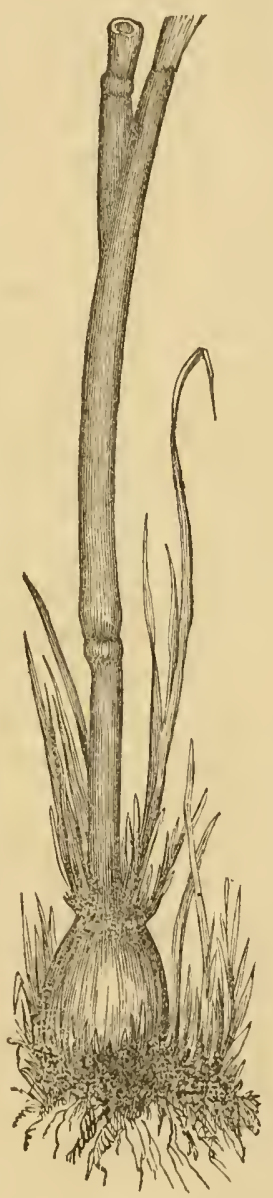

Fig. 97 .

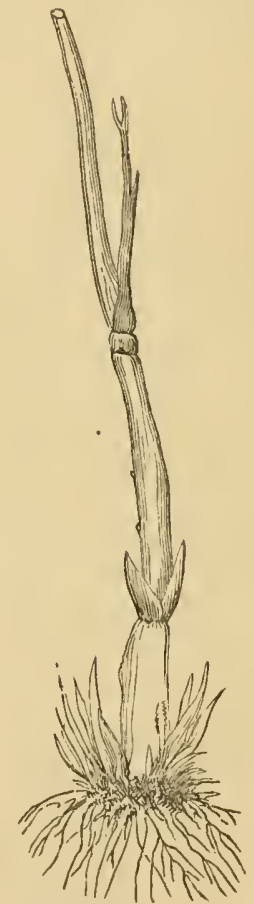

Fig. 99 .

5. The tubers, together with one or two of the lower joints of the stalk, remain fresh and green during the winter, if left to take their natural course, but if, by any means, this green portion be serered, at any season of the year, the result will be the death of the plant, when it will appear as in Fig. 99. 
From these five propositions the following conclusions are drawn :-

1. That Timothy grass cannot, under any circumstances, be adapted for pasture; as the close nipping of horses and sheep is fatal to the tubers which are also extensively destroyed by swine if allowed to run in the pasture.

2. That the proper time for mowing Timothy is at any time after the process of desiccation has commeneed on the stalk, as noted in the third proposition. It is not very essential whether it is performed a week earlier or later, provided it be postponed till that evidence of maturity lias become manifest.

3. All attempts at close shaving the sward should be avoided, while using the scythe, and in gauging mowing machines, care should be taken to run them so high that they will not cut the Timotly below the second joint above the tuber.

I have frequently, during the past autumn, pulled up the bulbous roots of 'Timothy, from the stubble from which a heavy crop had been cut with the seythe, while in flower, for the purpose of studying the changes which were taking place in these tubers, and have found them very similar to those represented in Figs. 97 and 98, not only on moist, damp soils, but also on soils comparatively dry. Any farmer can satisfy himself of the correctness of these representations by a little observation in his own fields; and as the point is of practical importance, it is worthy of careful attention.

The facts above alluded to lare fallen under the observation of a practical farmer of Middlesex county, who says: "The proper time to cut Herds-grass or 'Timothy, is after the seed is formed and is full in the milk. It will then give about twenty per cent. more weight than when it is just coming into the blossom, and the cattle will eat twenty per cent. less and keep on their flesh. And I prefer also to cut it at that stage of its growth on account of the roots being better able to withstand the drought. It should be cut four inches from the ground, as most of the Timotliy is killed by mowing close and early before it lias come to maturity. I hare kept Timothy thick and strong in the land six years, by following this method. I have noticed that most of it lias died out by once or twice close and early mowing before the grass has come to maturity; if it is dry weather it is sure to die when so cut. I lost a whole 
field of it by mowing too close and early, and I consider the four inches at the bottom of coarse Timotly of little value."

If the seed is allowed to ripen it exhausts the soil far more than if cut in the blossom.

\section{MOIVING MACHINES.}

We now come to the methods of eutting grass. As this crop is one of the most important and valuable in the whole range of farming products, any practicable means offered to facilitate its harvesting in the best manner, and at the least expense, will naturally excite the interest of the progressive farmer. The ordinary method of cutting by the hand scythe is already too familiar to every one in New England to need a moment's motice in this connection, and I propose only to allude to a comparatively new method of mowing by horse or ox power, and chiefly to the success which has attended the use of machinery during the past season as indieated in the returns to the circular already given, and in reply to the second question, " Have you used a mowing machine, if so, what patent, with what power, and with what advantage ?"

The inducements held out by the Massachusetts Socicty for the Promotion of $\Lambda$ griculture, by an offer of a preminm of $\$ 300$, in the year 1855 , to the one who should make the most successful experiments in cutting grass by machinery, and of $\$ 1,000$, to be awarded in 1856, to the inventor or manufacturer of the best mowing machine, very naturally led our farmers to licsitate in procuring machines till the results of these trials were known. The number of affirmative answers to the above question was, notwithstanding, very considerable, and generally whererer used, the testimony is strongly in favor of the use of machinery.

In speaking on this subject I shall state simply the facts which have been returned to me by practical farmers, without expressing any personal preferences for any particular patent. By so doing, I shall give the farmer who designs to purchase a machine the means of forming his own judgment without the necessity of any bias from minc. I will simply state that my observation of these machines and their work has been extensive during the two past seasons, and that the improrements 
during that time have been very great in nearly all the patents which have fallen under my notice.

$\Lambda$ practical and experienced farmer of Hampden county, in answer to the circular says: "I use Manny's Patent Mower, manufactured in Woreester, by J. P. Adriance \& Co., and have cut more than one hundred acres in the two last scasons, without breaking a tooth or the point of a knife. The whole expense of repairs has not exceeded three dollars, and it is now in fine order for years to come. The power is the same as common ploughing. If the horses are permitted to stop but a short time, and that often, in hot weather, as when ploughing, I would as soon let my horses mow a day as plough."

$\Lambda$ farmer of Worcester county says: "I have used Ketehmm's and Manny's mowing machines. I prefer Manny's to Ketehum's. It draws much easier, and is easier to manage. I worked them both with the same horses. My mowing lots are small. Farmers with large lots can use the machine to greater advantage than I can, but on my small lots it saves nearly two-thirds the cost of mowing, and all the cost of spreading." Another in the same county says: "In July, 1854, I used Ketehum's Patent Mower, with which, after many failures and repeated discouragements, I succeeded in cutting the crop of grass, and made consiclerable saring in the cost of getting the crop, but was of the opinion that great improvements were necessary. In 1855 I used the same patent altered, but not improved, by an iron frame and cutter bar. The present season I have used the Manny patent, manufactured in Worcester, and can say that it is a labor-saring machine for the farmer. The Manny is far superior to the Ketchum, for lightness of draught and the slowness of specd required in uneven places; the lever by which the cutter bar is raised or lowered at pleasure, - the perfect arrangement of the knives that conld not be clogged or stopped in more than fifty acres,- the convenience of transporting it on its own wheels from one lot to another, and last, not least, combining, as it does, the reaper, renders it one of the most perfect machines that has come under my notice. In regard to the profit of mowing by machinery, it lias cost to secure the hay on this place, on an arerage, about $\$ 100$ a year for extra labor. This year but $\$ 34$, allowing nothing for the labor of horses."

A practical farmer of Berkshire county says: "I have used 
Manny's combined machine for the two past seasons, having cut all my hay and grain with two horses. The first great adrantage is that I cut my lay on the day it is fit for cutting; seeond, I get more liay, as it is all cut up alike-no pointing out to be seen when the snow is a foot decp-and third, it don't make a

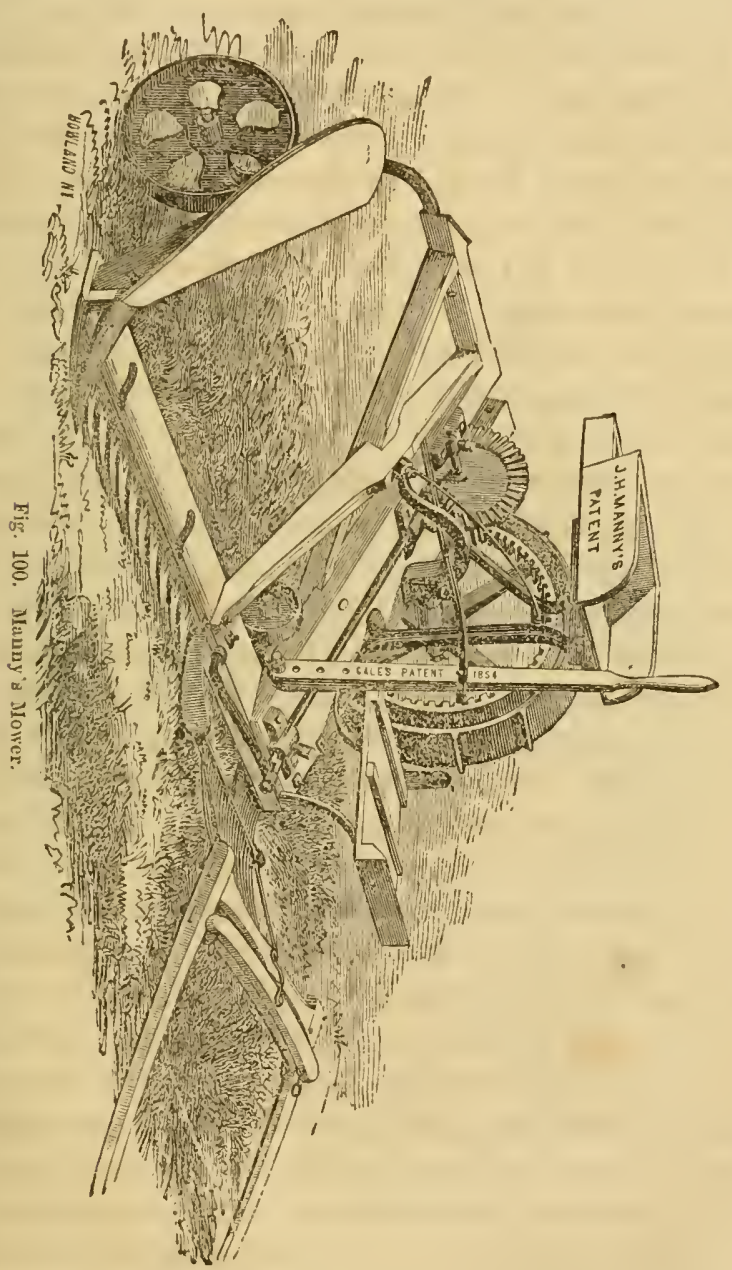

public house of my home during haying and harresting, for day laborers. The common farm liands with a Manny machine will do the haying with all ease, and at half the expense." Another in Franklin county says: "I lıave used Ketchum's patent with two horses, for three seasons. Think I sare from the 
expense of mowing and spreading by hand, together with the advantage derived from being able to cut all I wish to after the dew is off, one dollar per ton." An experienced farmer of Norfolk county says: "I have used Allen's patent, moved by horse-power, with great adrantage. Horses move slowly, as in ploughing-are less fatigued than by ploughing all day. I have mowed twelve acres per day, and ean mow easily and smoothly any grass, even heary and lodged clover, and on any surface where a seythe can be used. I regard it as of great use, saring much time and hard labor. It cuts clean and smooth, spreads the grass evenly, and requires only the labor of one man in the largest field, until the grass needs to be turned or raked up." Another in Hampshire eounty says: "We have used a mowing machine for the four last seasons, of Ketchum's patent. There are ten others of the same patent, and three of other kinds in town, all of which are in active use. They are all worked with horses, two on each. As to the adrantage gained by the use of the mowing machine, I hardly know what to say or how to reckon it. There are a number of points to be considered, some of which would be called an adrantage by some, which with others might not be so considered. But, the gain in cutting the grass must be apparent to all who have land smooth enough to work a machine on ; and in this connection it may be best to speak of the horse-rake with the mower, as one naturally follows the other. Our way of getting hay when the weather is good, is this: To cut and rake it into the windrow the first day. The next, open and turn it, if necessary, then rake it and cart it.

Now one man with a machine and horses, in the forenoon, and one horse and rake three hours after dimner, can put five or six acres of grass into the windrow every day if he chooses, which is as much as ordinary farmers in this vicinity wish to do, as our hay has to be carted from one to two miles, and that takes time. How many men will it take to do the same work? Any one can answer this to his own satisfaction, and as labor differs in price in almost erery section of the State, the actual cost wonld vary somewhat. But here it would take from fire to ten men to do the same work, varying as the burden of grass does per acre; for in lodged grass ten would hardly do.

"Then the advantage of having it done in good weather and cutting the grass when he chooses, whether in blossom or after 
it is fully ripe; I think this can be safely put down at ten per cent., and some call it as high as twenty per cent." $\Lambda$ farmer in another town in the same county says: "Hare not used any. There are a number of machines in the town. Allen's patent has done the best work this season. Ketehum's improved machine does pretty well. I think they are coming into use more and more."

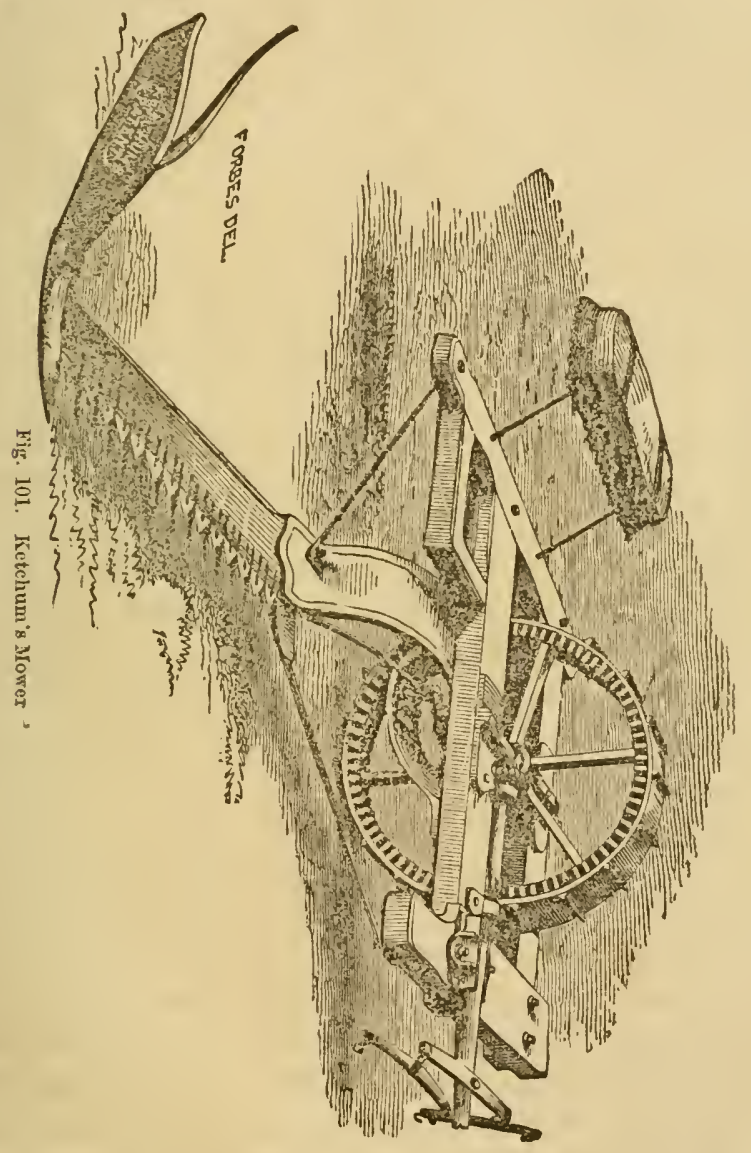

The following extract is from the statement of Dr. Loring, made to the Essex Society during the past scason.

"The ground upon which my machine (Ketchum's) was operated, furnished a very serere test of its power. Host part of it is clayey, heary soil, very wet in wet seasons and stiff and rough in dry ones. No special carc has been taken in laying it 
down. And I am confident that no machine but the strongest, could endure the wear and tear to which it is subjected on such a surface.

"No difficulty has been experienced in the rarieties of grass which I have cut. The heariest and the lightest have fallen equally well, and no tronble has been met in turning the corners or in driving the machine so as to aroid clogging.

"The experience of this season has conrinced me that on ordinary, rough New England farms, the Ketchum machine works almost to perfection. I do not mean to say it has no equal, for I have not experience to warrant such a statement. But in all rarieties of work, light grass and heary, lodged clorer and upright Timothy, rough land and smooth, I find that I can rely on its operations, without particular effort to secure for it any advantages. Its dranght is no trouble to such horses as a farmer ought to own. And it does its work without any extra and ingenious appliances.

"Of the economy of mowing machines, it seems to me there can be no question. I have found that the machine operated on the Pickman farm would cut grass enough in four or five hours in the morning to keep the laborers busy during the day, and as much as could be cured and got in with ease. The two seasons during which I hare witnessed the working of the machine, I have made it, in my mind, an absolute necessity, in all economical management of the farm, to which purpose alone I have had it applied."

But the great trial in this State the past year, was in competition for the premium of $\$ 1,000$ already alluded to, for the best mowing machine. Three farmers of well known good judgment were appointed to act as a committee. They gare all the machines entered a rery thorough and careful examination, saw the work of each, and made a report which has been returned to me in manuseript, and will shortly be published in full. In this report, after speaking of sereral machines, which, after a preliminary examination or trial, were ruled out for palpable defects, they say:-

The four other machines were tried upon another lot of grass, on patches of equal dimensions, each in succession, both when the grass was wet and dry. This was a heavy crop of clover, Timothy and 
redtop mixed, some of which was lodged. Portions of the lot were rolling, and the surfice gencrally quite as far from level as our ordi. nary grass fields, so that upon the whole, it was an excellent lot to test the machines.

They were also tried on a meadow bottom which had never been ploughed, where various wild grasses, both coarse and fine, were intermixed.

The trial, you will thus perceire, was a thorough one, and by it we were able to form a satisfactory judgment of the merits of the different machines. The remaining machines, and between which we were to judge, were patented or known as Ketchum's, Manny's, Heath's and the Allen machine, entered by R. L. Allen. The owners of the Ketchum machine allege that Mr. Allen has infringed upon their patent, and has no right to build or sell his machine except within the limits prescribed in a license procured from them, and that Massachusetts is not within those limits. However that may be, is of no consequence so fir as our report is concerned, for we did not regard the consideration of that question as within our province, and it therefore had no weight with us. The Ketchum machine, entered by Nourse, Mason \& Co., has probably been in use longer in this State and is more gencrally known than either of the others. The one which they entered for premium differs from those which have been built by them in years past, in having a driving wheel of comparatively small size, wrought iron substituted for castings wherever it was deemed practicable, and every thing about the machine so made as to reduce weight. In this they have succeeded, their machine with pole and whiffletrees attached weighing only about 460 pounds. The price of the machine has also been reduced from $\$ 100$ or upwards, to $\$ 75$. We think that in this, they have made no mistake, but that the reduction in weight is a great mistake. The difference in the amount of draft required to operate a machine of 400 pounds weight and another of 700 pounds weight, other things being equal, would probably be almost imperceptible, except by very accurate dynamical tests; and may it not be that the difference would then be found to be in favor of the heavier machine? Without entering into any speculation upon the matter, we think that it was a fact apparent to every careful observer that this light Fietchum machine actually required more power of draft when in operation than either of the four, and that the one which required the least power of draft was almost twice as heavy. So light, indeed, was it, that with the weight of the driver superadded, and driven at a rate of speed sufficient to cut the grass well,-which, by the way, is a little higher than that required by the 
other machines,-inequalities in the surface, even slight ones, caused it to bound in such a manner as to throw up the extreme end of the finger bar several inches above its true cutting level, leaving the stubble uneren and wary.

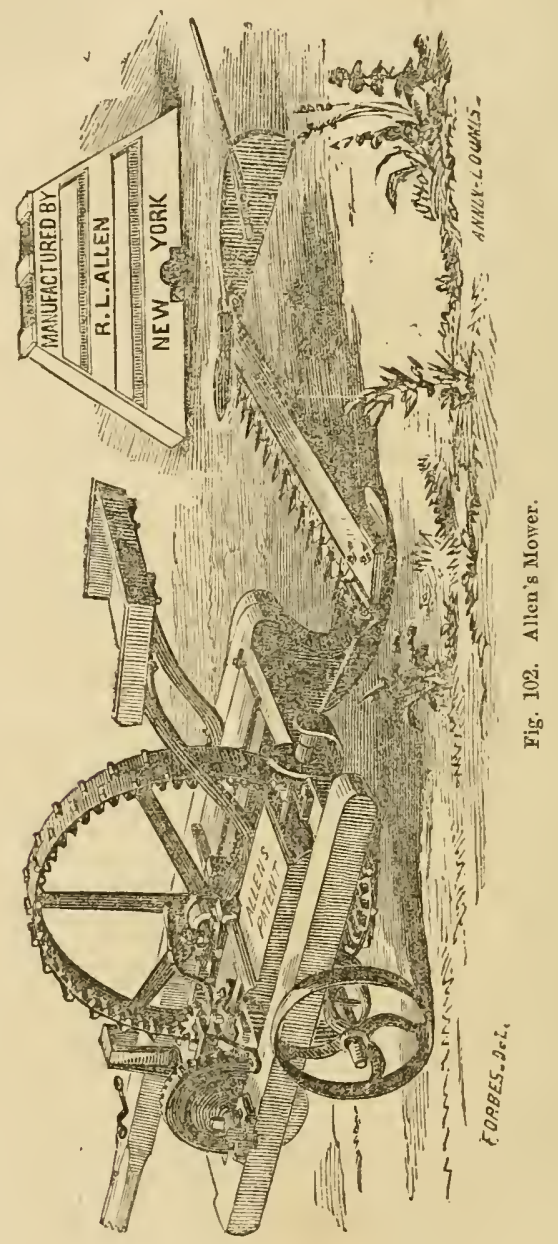

Allen's machine required less power of draft than the Ketchum machine. Its weight with pole and whiffletrees is about 600 pounds. No machine that we have seen is so readily thrown in and out of gear as is this. It has a wooden instead of an iron finger bar. In our opinion an iron finger bar is preferable. The weather cannot affect it as of necessity it must a wooden one, and the grass which falls upon it leares it a little more readily. Outside of the driving wheel is a 
light wheel which runs on a spring axle, and is claimed to be adrantageous in turning and in working the machine on a side hill.

The Manny machine also requires less power of draft than did the Ketchum machine. In this respect, the difference between it and the Allen machine was almost imperceptible. It has a wheel at the end of the knife bar, which greatly assists in turning and backing, and makes it much nore comfortable to transport from one field to another. We think that, other things being equal, a machine with a wheel at the end of the finger bar, has an advantage over a machine without it. Although very different in construction, we regard the Allen and the Manny machines as very nearly alike in point of merit, and if it had so happened that it was necessary for us to decide between those two machines, our judgment would have been made up cautiously and with much hesitation, for each has points of excellence which the other does not possess. Both these machines did their work generally well, but not so well as the work done by the Heath machine.

This, like the Manny machine, has a wheel at the end of the finger bar. Like that, too, it has a reel which may or may not be used, as circumstances require. But its cutting arrangement differs entirely from either of the other machines. They each have a single knife with the blades riveted to the plate and operating through cast iron fingers or guards, which, especially when the knife is dull, may be liable to get filled up and thus clog the blades. Instead of these, this machine has virtually a double set of cutters, the under set being stationary, projecting an inch beyond the upper, and thereby acting in the double capacity of guard and cutter. These, as well as the upper blades are each independent of the other, and each attached to its bar by a screw bolt. The upper set of blades is held down by a spring pressure bar, so that the operation is similar to that of shears, the grass being cut between two sharp edges, and the machine working nearly as well at one rate of speed as another. In case of aecident, therefore, a blade can be removed by any body and another substituted in an instant of time. Both the upper and lower cutters are made like the best edge tools in use, of the best east steel with wrought iron backs. The iron furnishing strength, the steel can be made as hard as desirable without so much danger of breaking by use, and being made hard do not require to be so often ground. The lower cutter or guard, as you may please to call it, is half an inch thick and one and one-fourth inches wide. The upper blades are about twice as thick as those used on any other machine. This machine very evidently required less power of draft than either of the others, and did its work the best. The Manny machine weighed about 600 
pounds. This weighed about 800 pounds. In its cutting apparatus, which is perhaps the most important feature of a mowing machine, we regard it as very much superior to either of the others. In its ease of draft, perhaps the next most important feature, we regard it as

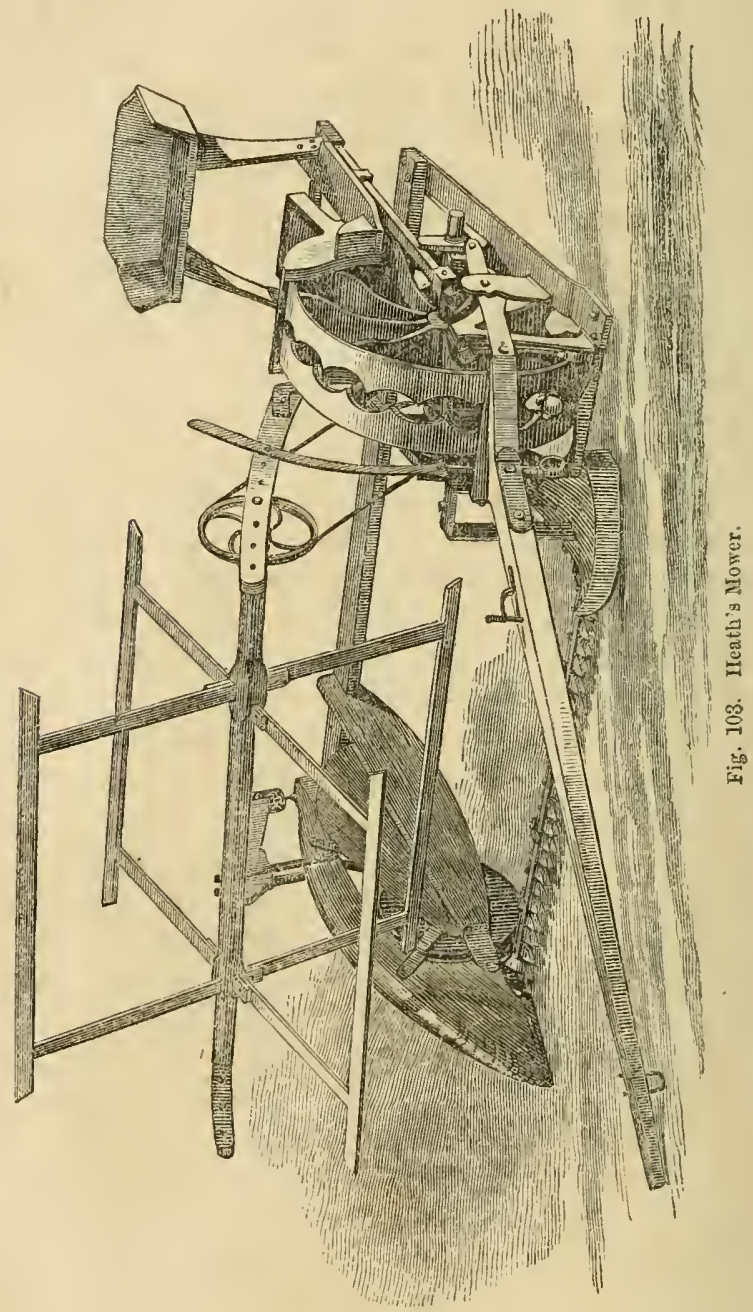

supcrior. We regard it also as less liable to clog than any machine with fingers or guards, like those of Ketchum, Manny and Allen. In other important fcatures it is equal to the other machines.

We therefore unhesitatingly, confidently and unanimously express 


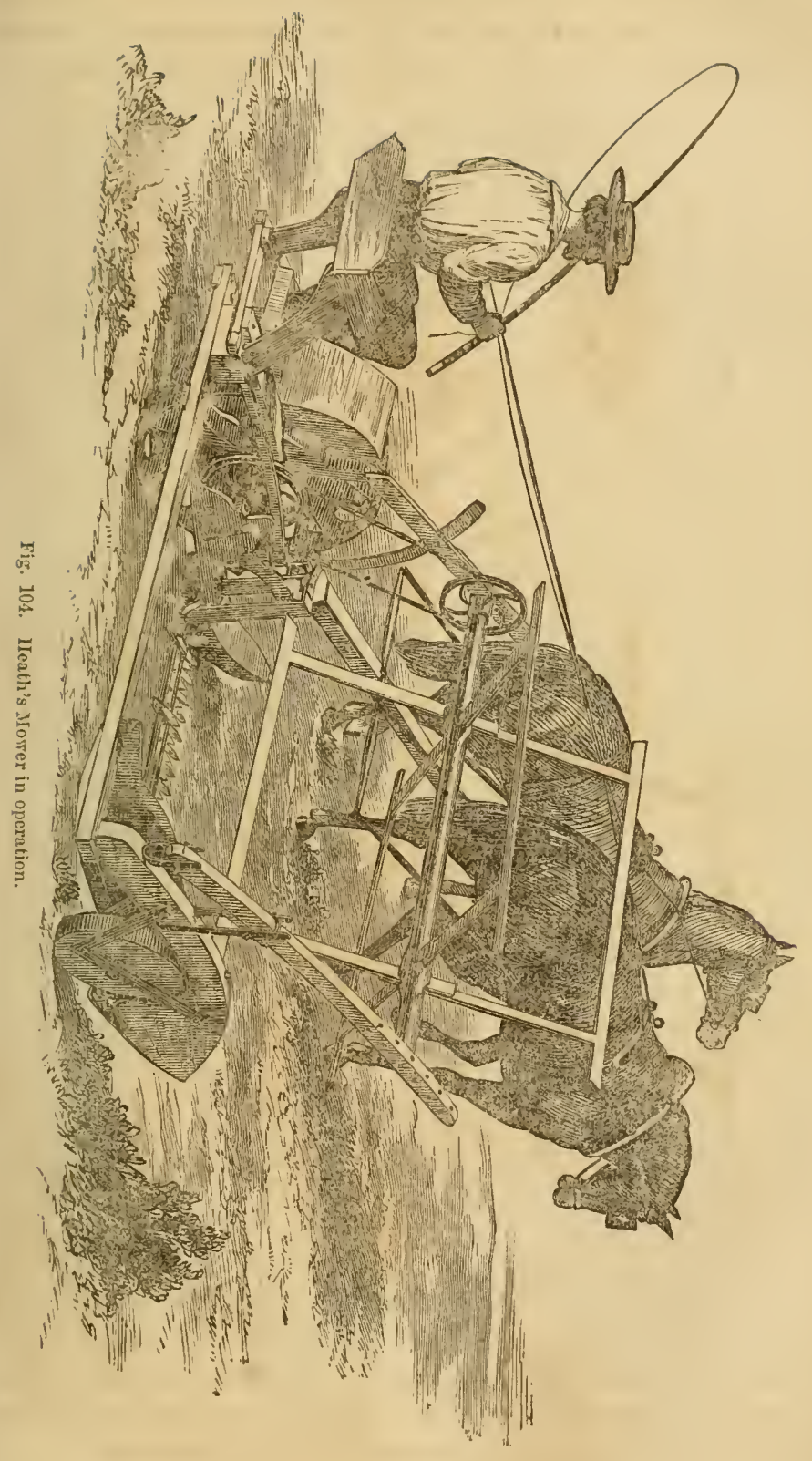



the opinion, that the Heath machine, entered by D. C. Henderson, is entitled to the premium of one thousand dollars, if that premium is awarded the present year.

\section{HEIGHT OF CUTTING GRASS.}

Writh respect to the height from the ground at which it is best to cut grass, the practice and the opinions of farmers differ widely, for while the answers from about half of the towns say that farmers generally cut as close as possible, the replies from others rary from foir inches to onc-half an inclı. Thus, fortyfour towns return, "as close as possible;" fourteen torns, "close, or very close;" sixteen towns, "from two and a half to three inches high ;" ten towns, "two inches high ;" twentythree towns, "from one to two inches ;" one town, "four inches," while some say, " it might be cut too elose," or "close cutting is injurious," or "most people cut too low," and many say, " close as convenient."

It would be difficult to deduce any general rule from the replies to the question, "At what height from the ground do you prefer to have your grass cut, and why?" A farmer of experience in Hampshire county says: "I should prefer to have my grass eut high enough to protect the roots from the hot sun. I have seen Timothy grass nearly killed by cutting close in a dry, hot time."

An intelligent, practical farmer in Middlesex county says: "I prefer to share pretty close, within an inch of the ground when smooth enough. I still remember some proverbial sayings of my teacher to this effect: 'An inch at the bottom is worth two at the top,' 'You are learing your wages behind you,' \&c. Possibly in very hot, dry weather, on a dry soil, some plants might be injured by a too close shaving, but I should not apprehend any harm, eren then, and as a general rule I prefer to have grass cut as close as it eonreniently can be." One of the most experienced, practical farmers of Plymouth county says: "Upland mowing grounds I do not like to have cut elose, having an idea that the hot sun and dry weather which often follow the mowing season will hare an unfarorable influence on the roots of the grass. Low and wet meadows I like to have mown close as possible. There, the heat of the sun is bene- 
ficial." A very successful, practical farmer of Worcester comnty says: "The lieight from the gromd at which it is best to cut grass, depends on the season, the soil and the grass. No grass, except on moist ground, should be cut so low in a very dry season, as it will do to cut it in a wet season. The natural grasses I like to have eut within about two and a half inches of the ground. Our old fields of eultirated grasses do not afford much afterfeed after the elorer is run out; what of stubble is left on them is lost, so 1 like to mow close."

One of the most observing, experienced and practical farmers of Hamplen county says: "I prefer grass cut from an inch and a half to two inches, as it starts much quicker to grow when cut at that lieight, than when shared close to the earth, as some that are called good nowers do their work. If it is true that all crops are benefited from the anmonia in the atmosphere, as I liave no doubt they are, judging from grass side by side, the one cut elose, the other two inches high, the grasses should have some leares left them to receire this benefit. Grass cut two inches high will keep growing, while that closely cut will be even weeks before it will show the first signs of life."

Another experienced farmer says : "Where I top-dress immediately after, I cut as low as I can, to save all the grass I can. If I do not top-dress I eut from two to three inches high, to protect and nourish the roots. I do not feed in the fall where I do not top-dress. I intend to manure all my natural upland mowing land and never feed my old fields." And another: "I like to cut ruther near the ground, for the reason that more hay is obtained. If the soil is in good condition, and not too dry, it will start arain immediately. I know some say cut high, the stubble will manure the land and protect the roots, de., hut I prefer to manure with something better for protection. I top-dress my mowing land and prefer a compost made of woollen waste and meadow mud for soil not rery wet; but for a cold, heavy soil, should prefer sand, or sandy loam to mix with wool waste. Apply fifteen cart loads of thirty bushels each, late in autumn."

A farmer of Franklin county says: "The farmers here eut their grass as near the ground as they can conveniently, without any particular reason for it, except to increase the quantity of hay." Another says: "I prefer to have my grass cut at two 
inches from the ground, where the land will admit of it. Three inches at the bottom is more raluable than six at the top; besides, it leaves the land in better shape for the next year." Another intelligent, praetical farmer says: "It has been diffcult to get mowers that would ent close enough, but the mowing machine gives better satisfaction in that respect." And "another: "The general practice in this vicinity is, to cut as low as possible, in order to get all the fodder ; unquestionably it would be better for the ground and the next erop, to ent the grass a few inches above the ground, to shield the roots, still, I consider, to ent low, followed by a top-dressing, is a better way, and leares a smoother surface to mow orer the following year."

An intelligent farmer of Berkshire county says: "Three inches. If pared too close, the hot sun kills or impairs the rigor of the roots, and stubble of some length retains the snow and gives protection from the winds of winter."

A rery successful, practical farmer of Essex county says: "I prefer to cut English grass about three inches from the ground, beliering that cutting it closer lets the rays of the suin to the roots of the grass, the intense heat of which, withont any screen or shade, greatly impairs the growth of the plant, particularly in a dry season." Another of Middlesex, says: "Cut Timothy grass rather high; finer grasses, and especially wet meadows, should be cut as close as practicable; on upland, in fine grass, there is great loss to the crop by cutting high ; in wet meadows high mowing gives the mosses and cranberries headway, which will eat out the better grasses."

Thus, the testimony on this point is somewhat conflicting; but many have noticed the injury inflicted upon Timothy by low eutting in dry weather, sufficient, perhaps, to establish the principle alluded to on a preceding page. Most concur in saying that the finer grasses can be cut lower with safety, particularly if the season be not too dry. Much, undoubtedly, depends upon the soil and the season.

\section{CURING OF HAY.}

We liare seen that grasses attain their full development at the time of flowering, and then eontain the highest perecntage of soluble materials, such as stareh, sugar and gum, and that 
these, with the nitrogenous compounds, then, also, most abun dant, are of greatest value as furnishing the nutriment of animals, while woody fibre and mineral matter, though important as giving bulk to the food, are insoluble and least nutritious. We hare seen, also, that in the transition from the flowering to the ripening of the seed, the stareh, sugar, \&c., are gradually transformed into woody fibre, in which state they possess no" nutritive qualities, and are, of course, of little value. This fact, which is perfectly well established by careful experiment and accurate analysis, confirmed as already seen by intelligent practice, is of great importance as indicating the condition in which most of our eultivated grasses should be cut, and our practice is pretty uniformly consistent with it.

But there is another equally instructive suggestion in these transforming processes, and it is this: If grass is cut in a condition ever so suceulent, and before the transition of sugar, \&c., into woody fibre has eommenced, there will eren then be some loss of sugar and starch from the action of heat and moisture, especially if the grass is exposed to the rain in the process of curing, and lignifaction, or change to woody fibre takes place to considerable extent, dependent, of course, on the length of time it is exposed to air and light; so that grass eured with the least exposure to the searching, sifting winds, and the scorching sunshine, is, other things being equal, more nutritious than grass cured slower and longer exposed, howerer fine the weather may be. In other words, grass orer-cured in the process of hay making, contains more useless, woody fibre and less mutritive qualities, than grass cured more hastily and housed before being dried to a crisp. There ean be no doubt which of the two would be most palatable to the animal. Some loss of nutritive elements must, therefore, take place in the process of euring, however perfeet it may be, and the true art of hay-making consists in euring the grass just up to the point at which it will do to put into the barn, and no more, in order to arrest the loss at the earliest possible moment. And this fact of the loss of sugar and starch, or of their transformation into woody fibre by too long exposure to the sum and wind, I think equally well established as that any transformation at all takes place, and as equally suggestive.

But on this point, far greater difference of opinion exists 
among practical farmers, some considering one good lay day sufficient, while others require two and sometimes three, as if it were not possible to dry it too much. Our practice in this respect is, I believe, better than it used to be twenty years ago. Most farmers now think that grass can be dried too much as well as too little, and that the injury and loss in the erop is equally great from over-curing as from housing green. A practical farmer of Hampshire county says: "One good hay day is sufficient to dry Timothy, redtop or wet meadow. I think farmers lose more by drying their hay too much than by not drying it enough."

An experienced farmer of Hampden county says: "As far as my experience and observation extend, I think farmers dry their hay too much as a general thing. Grass should never be dried any more than just to have it keep well in the mow. I think it is best to get in hay as green as it will possibly do, for it contains more juices, which constitute its ralue."

A practical and experienced farmer of Worcester county says: "Redtop is a more difficult grass to make into hay than Timothy. To make hay from any grass, it is highly important that the swaths, of the hand scythe, be well shaken; here lies the secret of making hay erenly, without haring green, heary locks. If the burlen is heary, time in making the hay, if eut in the morning, will be gained by turning it by one o'clock, $P$. M., and then putting it into good sized cocks while it is warm. If the weather be clear, according to my experience, this hay will do to cart the second day without giving it much attention - the sap has become candied and it is fit for the mow. The exposing the hay to the air on the second day, by pitching, is of essential benefit. When carted the same day it is mown, unless dead ripe, it will be withy, clammy, and will be likely to smoke in the mow; in which case the hay has lost much of its raluable quality.

"To keep it till the third day and expose it to the rays of the sun erery day, as some practice, dries out the juices and the stem becomes liard and brittle-the life of the hay is gone to some degree. Our mothers and grand-mothers used to dry herbs in the shade-I hold to curing hay in the cock."

Another practical farmer in the same county says: "NIy way of making Timothy and redtop is to mow it early in the morn- 
ing, and when the dew is off spread it well. I like to dry it in one day's sun if I possibly can ; if not, put it into cocks before night, then get it into the barn as green as I can and not lave it hurt. I do not want my hay all dried up. It injures it. Wet meadow I put into the barn on the day it is eut, if the weather is suitable for curing it."

A farmer of Berkshire county says: "If the weather is good and the grass not too heary, we eut in the forenoon and get into the barn in the afternoon. If the grass is heavy and the weather not good, cut in the forenoon and turn over the swaths at night, spread and get in the next day. I do not believe in drying hay as much as some do. If not quite dry, two or three quarts of salt to the load will preserve it, and it will be the better." Another in the same connty says: "I prefer to eut liay in the blossom on a good hay day in the forenoon, and it is fit for the barn, if raked with the horserake and care is used to turn it over and bring the green grass to the sun, by two or three o'elock in the afternoon of the same day. Much hay is spoiled by being dried too much."

A furmer of Franklin county says: "Timotlyy will dry sufficient for me in one good hay day. I dry less and less every year. If there is no moisture on it there is little danger of hurting after it is wilted." He cuts his swale hay before it matures and while it is quite green, and lets his upland grasses stand till they are fully developed and commence changing their deep green color. "I think it will keep the same stock longer and better if eut at that age.." Another experienced farmer of Berk-hire county says: "Mry way of making hay is to eut when in blossom, in the morning, shake it out evenly orer the ground, turn it orer at eleven o'elock, and get it into the barn on the same day if the weather is good. But if the grass is rery heary, I put it into cocks orer night. I consider it made as coon as dry enough not to heat in the mow. To get drier than this is an injury to the hay."

One of the most extensive and experieneed stock feeders in this State, a practical farmer, says: "I prefer to cut all English or swale grass from the tenth of June to the first of July, including Timotlyy and clover in the same time. More than thirty year's experience has convineed me that hay secured in the above time,-or just before coming into blossom,-will 
make cows give more and better milk and butter, will put more fat on animals for the slaughter, with four quarts of meal per day, than eight quarts of meal with hay well secured from the first of July to the first of August. That will give the second crop, if you wish, time to grow, and it may be cut the last week in August or the first week in September ; there will then be a erop of fall feed, which most farmer's prize very highly. If you do not wish a second crop, the feed by early mowing is rery valuable. On the other hand. if the grass is cut late, the liay is not only poor but the feed is mere nothing. Every farmer of my acquaintance admits that the hay cut early is far superior to that cut late, unless it be those that are in the habit of sclling hay; eren that class must lose in the weight of their crop by late cutting. Many buyers have not yet learned the difference between early and late eut hay, when the real differcuce is, oftentimes, from four to six dollars per ton. Working horses and oxen will keep in better condition with half the grain when fed upon early cut hay; will look sleek and their eyes will be bright."

A farmer of Hampshire comnty says: "My method is to cut with the mowing machine, which leares the grass perfectly spread. It is turned over between one and two o'clock in the afternoon, and while still warm and before the erening dew falls it is put into cocks. It is spread and turned the next morning, and at one o'clock is ready for the barn. I cannot tell on paper, the precise point of dryness at which hay should be housed, but with my luands, cyes and nose, I cân judge when it is dry cnough not to hurt in the mow, and not so dry as to crumble or to have lost any more of its virtues than necessary. The less drying the better, if it does not injure in the mow." Another practical furmer says: "I prefer two days, but want to have it lay thick together and stirred often the first day and but little the second. In this way the luay retains more of the juices, smells sweeter, looks greener and the cattle like it much better. Hay should be cured so that it will not heat in the mow and no more." Another says: "Hay may generally be dried enough in one good lay day with proper care, to be left orer night in the cock and carried to the barn the next afternoon without spreading. Hay may be dried too much as well as too little." "Timothy and redtop," says a farmer of Berk- 
shire county, "carefully spread as soon as the ground between the swaths is dry, and, if heary, turned alout noon, will dry sufficiently in one day, if a clear one, to be put into the barn before sunset. I believe many dry their hay too much. Never dry it so as to make it brittle when twisted in the hand."

These, and many other extracts of a similar import which might be given, did space permit, indicate with sufficient distinctness the prevailing practice among the best farmers, but as constantly intimated, it is rery common to find hay dried far too much. Every farmer is aware of the importance of keeping his grass and hay as free from dew and water as possible. An exposure to rain washes out much of the soluble constituents of the grass, leaving a useless, brittle, woody fibre. Grass and hay are greatly injured by remaining too long under a hot sun without being turned. A somewhat different method is adopted for

Clover.-The natural grasses when cut for hay are generally spread and dried as rapidly as possible, in order to secure them in the best manuer. Experience has proved that the same method is not applicable to the clover crops. It requires a longer time to cure it properly, and if exposed to the scorching sun it is injured even more than the natural grasses, since its succulent leares and tender blossoms are quickly browned and lose their sweetness in a measure, and are themselves liable to be wasted in handling over. Most good farmers, therefore, prefer to cure it in the cock. A practical farmer of long experience in Worcester county says: "I prefer to mow clover when it is dry, free from dew; let it wilt, and the same day it is mown fork it into cocks which will weigh from forty to fifty weight when fit for the barn. Do not rake and roll it, that process will compress it too much.

"According to the weather and my convenience I let it stand -it will settle and turn the rain very well, and will answer to put into the mow while the heads and stalks are yet green and fresh. When fit to cart, the stalks although green, will be found to be destitute, or nearly so, of sap-the sap has candied and the clover will keep. On the day of earting turn the cocks over, expose the bottom to the sun an hour or so, and to a ton of hay add four to six quarts of salt in the mow.

"Good clover-not rank-cured in this way, I consider to 
be worth nearly or quite as much as clear Timothy, to feed to a stock of eattle; and for milch cows, I consider it to be by far preferable to Timothy. Good clover hay will keep up the quantity of milk, while Timothy will diminish it."

Another practical farmer of the same county, in one of the best farming towns in the State, says: "My method of euring clorer is this: what is mown in the morning I leare in the swath, to be turned orer early in the afternoon. At about four o'clock, or while it is still warm, I put it into small cocks with a fork, and if the weather is farorable it may be housed on the fourth or fifth day, the cocks being turned orer on the morning of the day it is to be carted. By so doing, all the heads and leares are saved, and these are worth more than the stems. This lias been my method for the last ten years. For new milch cows in the winter, I think there is nothing better. It will make them give as great a flow of milk as any hay, unless it bo good rowen. For working oxen and horses its value is about one-quarter less than Timothy."

$\Lambda$ practical farmer of Hampshire county says: "I can hardly state my own opinion of curing clover. When the weather bids fair to be good, I mow it after the dew is off, and cock it up after being wilted, using the fork instead of rolling with the rake, and let it remain several days, when it is fit to put into the barn." Another in the same county says: "I mow my clover in the forenoon, and towards night of the same day I take forks and pitch it into cocks and let it stand till it cures. The day I cart it I turn the cocks over so as to air the lower part. I then put it into the mow with all the leaves and heads on, and it is as nice and green as green tea. I think it worth for milch corrs and sleep as muclı per ton as English hay."

A farmer of Middlesex county says: "I have found no better hay for farm stock than good clover, cut in season. For milch cows it is much better than Timothy. It keeps horses that are not worked hard better than any liay. And small clover, as the rowen crop, is better than any other kind for calves. Clover is not good market hay, as it wastes in removal from the barn. Stable keepers give much more for coarse 'Timothy that cannot easily be drawn through a rack." A farmer of Barnstable county says: "We mow clover in the forenoon and let it lic in the swath and put it into small cocks in the afternoon. If the 
weather be fair on the third day, open it to the air and sun for two or three hours and then put it into the barn. I have found clover cured in this way keep sweet and free from mould, and of equal ralue with other hay." Another says: "I have tried three different ways of curing clover. One was, to make it in the same manner of other grasses; another, to dry it one day in the swath till wilted and then pitch it into cocks to stand some days, according to circumstances; and the third was, to give it one good day's sun, turning it orer and getting out the water, and mixing it in the barn with old hay or straw. I managed in this way a year ago, the weather being rery 'catching,' cut and dried it as much as possible in one day and carted it into the barn the same afternoon. I mixed it with some old swale hay that had been left over, placing a layer of old hay then a layer of clorer, building it up in a square mow. My neighbors laughed at me and said I should burn my barn down by putting in that 'green stuff.' But I must say I never had better clover hay than that. The cattle would eat all the meadow, or swale hay, as well as the clover. There was not a particle of smoke about it on feeding it out. When cured in this way or by the second method, in the cock, I think clover hay is worth two-thirds as much as good English hay to feed out to farm stock."

From what has been said in these extracts, whicl might be multiplied, did space permit, it appears evident that good farmers appreciate the importance of so curing clover as to preserve its tender and succulent foliage. They are careful not to orerdry it, for fear of loss of the blossoms and the leares. But it is not uncommon among thriftless farmers, to handle it in such a way that the best parts of it are shaken ofi and destroyed.

The method detailed in the last extract, of mixing clorer with a poor quality of hay or straw, has sometimes been adopted with great success, the clover imparting its fragrant odor to the hay with which it is brought in contact, greatly improving its quality, while its own value is preserved without injury. It is not only a matter of convenicnce oftentimes, to have the clorer so secured in catching weather, but on careful experiment may be found worthy of being more generally practiced.

The general testimony of practical farmers as to the value of clover hay as compared with that of Timothy and redtop, 
our prevailing natural grasses, varies exceedingly, some making it of equal value, others estimating it at onc-half and from that to two-thirds and threc-fourths.

CORN Fodder.-The practice of raising Indian corn to cut and feed out green by way of partial soiling, is very common in New England, as already intimated, in speaking of the natural history of the grasses. This culture lias been carried still farther by many farmer's, and many acres are raised in various parts of the State for the purpose of eutting and curing for winter use. And now that great hopes are entertained by many of the utility of the culture and use of the Chinese sugar cane, which, it is thought may be raised, cut and cured in the same way and for the same purpose, it is important to allude to the most approred methods of curing, though they may already be familiar to most practical farmers.

The common practice with regard to this crop, and which has been already partially stated, is to sow in drills from two and a half to three feet apart, on land well tilled and thoronghly manured, making the drills from six to ten inches wide, with the plough, manuring in the furrow, dropping the corn about two inches apart and corering with the hoe. In this mode of culture the cultivator may be used between the rows when the corn is from six to twelve inches high, and unless the ground is very weedy no other after culture is generally needed. The first sowing usually takes place about the 20th of May, and this is succeeded by other sowings at intervals of a week or ten days, till July, in order to have a succession of green fodder. But if it is designed to cut it up to cure for winter use, an early sowing is generalty preferred, in order to be able to cure it in warm weather, in August or early in September. Sown in this way, about three or four bushels of coru are required for an acre, since if sown thickly, the fodder is better, the stalks smaller, and the waste less.

The chief difficulty in curing corn cultivated for this purpose and after the methods spoken of, arises mainly from the fact that it comes at a season when the weather is often colder, the days shorter, and the dews heavier than when the euring of hay takes place. Nor is the curing of corn cut up green, so easy and simple as that of drying the stalks of Indian corn cut above the ear, as in our common practice of topping, since then the 
plant is riper, less juicy, and cures more readily. The method sometimes adopted is to cut and tie into small bundles, after it is somewhat wilted, and stook upon the ground, where it is allowed to stand, subject to all the changes of the weather, with only the protection of the stook itself. The stooks consist of bunches of stalks first bound in small bundles, and are made sufficiently large to prevent the wind from blowing them orer. The arms are thrown around the tops to bring them together as closely as possible, when the tops are broken over or twisted together, or otherwise fastened in order to make the stook "shed the rain" as well as possible. In this condition they stand out till sufficiently dried to put into the barn.

But Indian corn stooked in this way often becomes musty or corered with dust, while the rains often soak it thoroughly and wash out much of its soluble matter, and its nutritive value is in a great measure lost. Besides, every one knows that to cut up a green plant, as a willow or any other thriftily growing plant or shrub, and set it up with the cut end resting upon the ground where it can still derive moisture from the soil, will prevent its drying. There can be no doubt, also, that the exposure to the sun, wind and rain, greatly injures it by removing much of its sweetness, or changing it to woody fibre, while it takes from it its beautiful fresh green color.

To aroid the losses necessarily attending these modes of curing, some hare suggested kiln drying as far preferable, and, on the whole, as economical. I have known the experiment tried in one or two instances with complete success, the fodder coming out with its fresh green color, and apparently better relished by cattle than that dried in the ordinary way. This method appears to me to be worthy of much more extended and careful experiment. The kiln need not be claborately or expensively contrived. The process of drying would be short and the labor slight.

Another mode which has been suggested is to hang it up in sheds open to the air, precisely as tobacco is cured in the western part of the State. This process would be longer, but the nutritive qualities of the plant would probably be better preserved than if cured in the open air with the exposure to the frequent changes of the weather. It is hardly necessary to say that if it is proposed to cure in this way, it should be liung 
up thinly and the air should be allowed to cireulate through it. After being well dried it is taken down and stowed away in the barn for use. This method aroids the trouble of stooking and the liability to injury from rains and dews, which blacken the stalks, though it requires considerable room, and is, of course, attended with some additional labor.

\section{THE HORSERAKE.}

This implement has come into universal use, and no farmer of any extent would be withont one. It met with great opposition and encountered great ridicule on its first introduction, but has survired it all aid become indispensable in all thrifty and economical farming. I shall do no more than give the authority of practical farmers in answer to the thirteenth question of the cireular, "Have you used a horserale, if so, what patent, and with what advantage?"

To this, an experienced farmer of Middlesex thus replies: "I have used rarious horserakes for fifteen years. Much labor is saved by the use of any kind of horserake that has been introduced within that time.

"Horserakes are on a footing different from mowing maehines. Grass may be cut in the morning, in the erening, or in a cloudy day. But hay must be raked at the rery right time, or it may be entirely spoiled. It is, therefore, quite important to do work quick when the time for doing it comes. With a good rake a man and horse will gather more hay in half an hour than a laborer with a handrake usually gathers in a long afternoon -that is, one acre; this is considered a half day's raking by handrake.

"The independent rake operates quite well. The old revolring rake (Fig. 105) costs about the same.

"The spring-tooth rake is patented, as I am informed. One objection to this is, that the wire teeth seratch up too much earth. This is seen in Fig. 106.

"Buckminster's patent was obtained about sixteen years ago. His rake is quite simple in form and will gather more hay than either of the other kinds, in an hour. But the operator must walk, and a boy is wanted on the horse. The price is 
four to five dollars, as any carpenter or wheelwright can make them."

A practical farmer of Woreester county says: "I have used what is ealled the independent horserake, Delano's patent, I beliere, and with great advantage. I have also used the revolving and the spring-tooth rake. I prefer the independent. In short, it is my opinion, that no modern invention of agrieultural implements has made so great a saving over the old method of performing farm work, as the independent horserake."

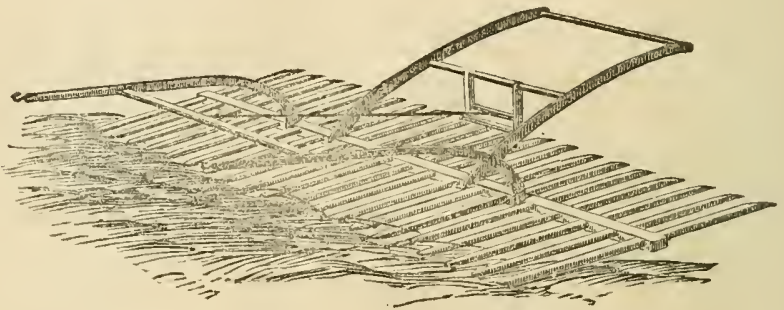

Fig. 105. Revolving IIorserake.

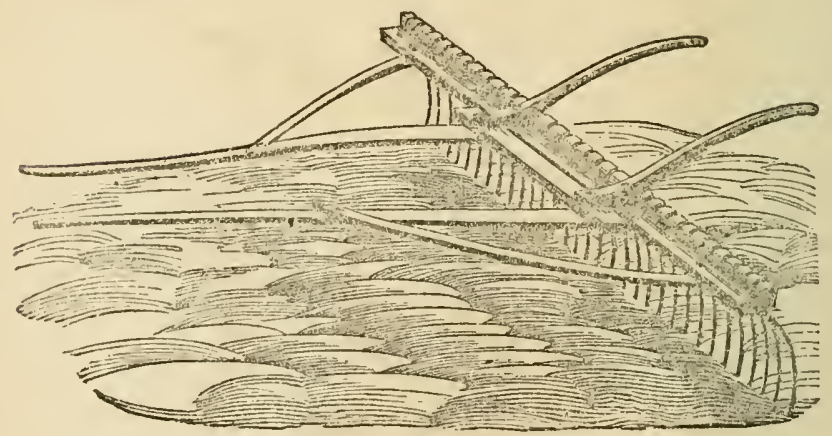

Fig. 106. Spring-tooth Horserake.

A farmer of Norfolk county says: "I have used Delano's independent rake for several years. I regard it as a valuable implement, saving thirty per cent. at least, of labor and time. This rake ought to be made of better materials and with more care, or it will be given up for some other." This rake is seen in Fig. 107. The complaint that it is very badly made and constantly liable to get out of order in consequence, is very general.

$\Lambda$ practical farmer of Franklin county says : "I have used a revolver ever since I commenced working on a farm, and would 
as soon think of haying without a pitchfork as without a horserake."

Another experieneed, practical farmer of Worcester county says: "I used an iron-toothed rake three seasons, and I thought with profit, but I bought one of Delano's independent rakes, and I think it is worth three times as much as any irontoothed one, as it does not make the hay so dusty as the others. It is also a great saring in time and labor, as a boy twelre years

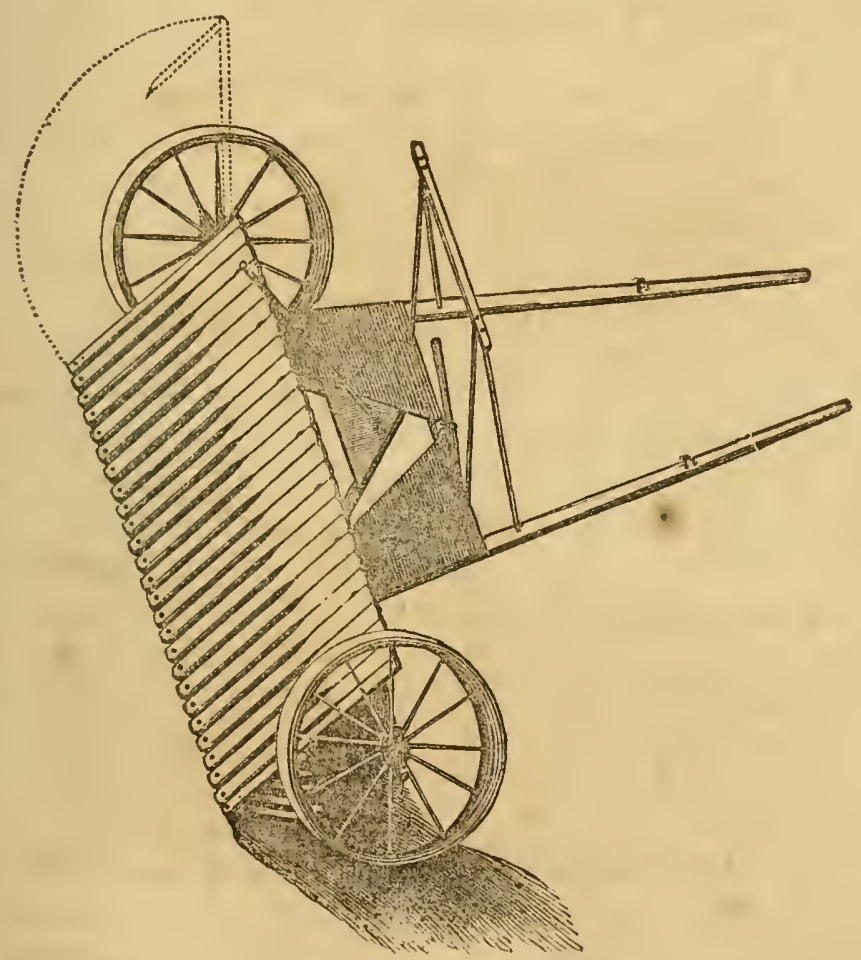

Fig. 107. Independent Horserake.

old will rake as much with Delano's patent, as a man and boy with any other kind I have erer secn, and do it better. I have used one of this kind for four seasons, and it lias not cost me twenty-five cents a year for repairs, although my farm is rough and rocky."

Another says: "The horserake is a great labor-saving implement. For several successive years I used the rerolving horserake to good advantage. There was labor in it, but it is a 
good rake. Delano's patent-the independent tooth horserake-lias taken the place of the revolver with me; it is managed with much more ease, the teeth each one acting independent of all others, at all times laying on the surface, whether even or otherwise, will rake cleaner than the revolver, and will not get so much dirt on the hay as will the spring-tooth."

And another: "I use the wire-tooth. The independent, or wheel rake is used some; both are good. I cut about sixty tons of hay, and my rake I have no doubt sares me $\$ 20$ erery year. First in labor, and second, in quality of hay-every thing being raked at night." Another says: "We have used the rerolving horserake for the last ten years or more, and my opinion is, that could I have my choice between six men or a horse and rake, after dimner, with a quantity of hay to secure, I should take the latter."

A very successful farmer of Essex county says: "We formerly used the revolver with good success; but for the last four or five years we have used Delano's independent horserake and like it better than the revolver, as it is easier for the horse, easier for the person who uses it, and rakes better on uneren land. The great difficulty with the independent rake is, that it is so wretchedly made, that our farmers cannot depend upon it, and they complain of its getting out of order at times when they most need it. They are compelled to resort to the use of other patents which are not so convenient, on account of their being better constructed." Another in Hampden comnty says: "I have used the independent horserake for seven years, and find it a great labor-saving machine. It has not cost me a dollar to keep in repair and it is now as good as new, thorigh most farmers who use it say it is liable to get out of order from being very badly manufactured. This, if true, is enough to condemn any farm implement, because farmers are not generally so situated as to be able to afford such frequent mishaps."

Still another patent, which promises to be a great addition to our present facilities for raking hay, has been introduced under the name of "Carpenter's Improved Horserake." This rake is seen in Fig. 108. It was patented in August last, and the parties interested claim for it very important advantages over the horserakes now in common use. The driver rides upon the 
rake comfortably seated, and by means of a lerer, which he ean more at will, and withont changing his position, frees the hay gathered in the teeth of the rake.

It is a donble rake, made for both smooth and rough ground. On smooth ground the wheels may be used, while on rough

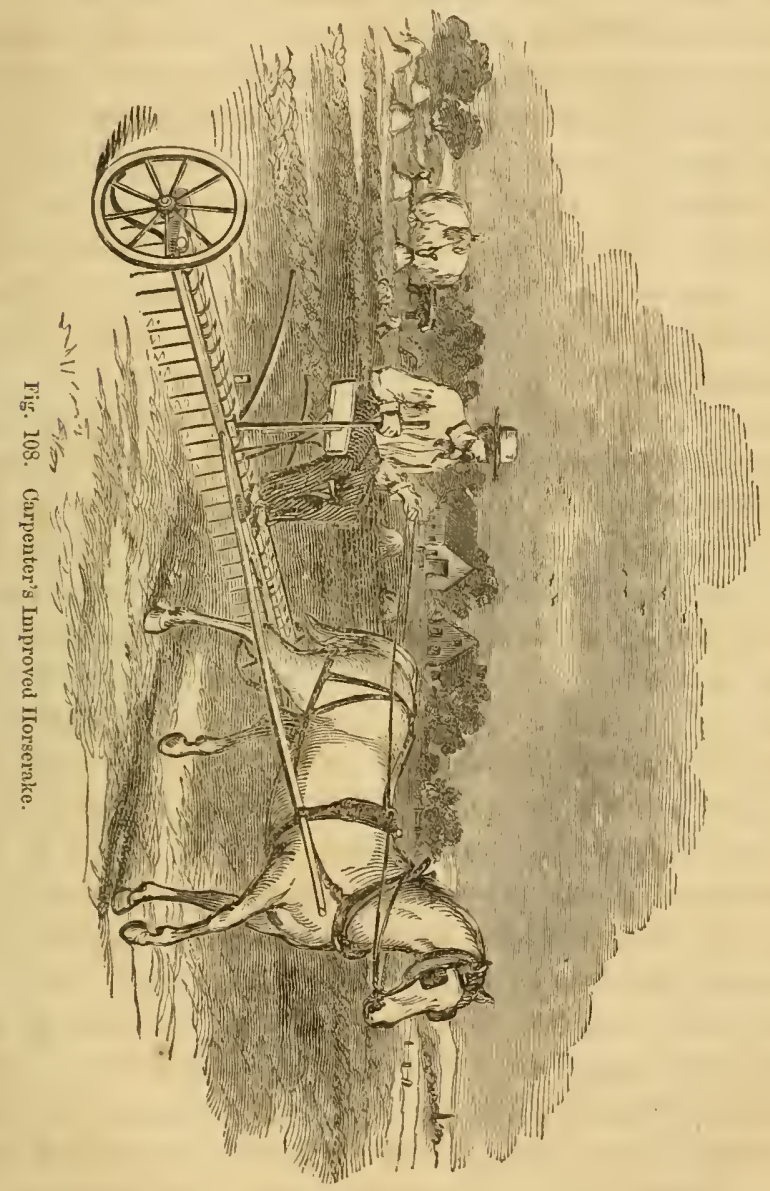

ground the driver may walk belind and manage it with ease, and adapt it without diffieulty to inequalities of surface. It is simply constructed, and is manufactured by Nourse, Mason \& Co., of Boston. As it is a new implement, and has never been used, to my knowledge, in this State, I camnot speak of it from personal observation or experience.

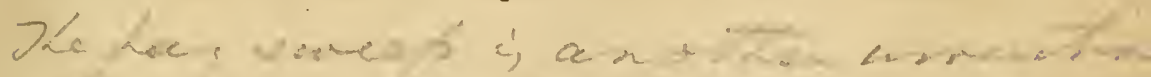




\section{HAY CAPS.}

The frequent losses to which farmers are subject in making hay, has suggested the use of hay caps, made to corer the cocks and protect them from the weather. It is but recently that their use was introduced, and like most novelties, it has met with objections from some, on the score of economy, while their nse is as strongly approved by others, on the same ground. I hare often seen them used, and the time taken to cover an acre of grass or hay in cock partially cured, is less than most would naturally suppose. Where they are to be used, less care is needed for "trimming down" the cock and putting it in a condition to shed the rain in the best possible manner.

An experienced, practical farmer of Worcester county says: "I have used hay caps with good results. I have one hundred made of cotton sheeting two yards square, with pins attached to the four corners with strong twine; the hundred cost me just forty dollars; I think they hare sared me twenty dollars this year. I had at one time this season one humdred and thirty cocks standing out in a six days' storm. One hundred were corered, and not having caps enough, thirty were left uncorered. The uncovered was worth but little, while the covered was passable hay. I stooked some oats which I capped -they stood a two days' rain without injury." And another : "Our caps are made of heary five-fourths cotton cloth, cut square with four little loops through which we run a slim wooden pin into the hay cock; the pins hold it better than weights in the eorner. Ours cost twenty-one cents apiecelave saved the cost in one storm this season."

A practical farmer of Hampshire county says :-

"In reply to your question as to the utility of hay caps, it gives me pleasure to say, that, after using them constantly, for the last seven years, I consider them of the first importance in the most critical branch of farming.

"I can safely affirm, that my hay has been intrinsically worth, on the average, one or two dollars a ton more than my neighbors', which has been proved lyy the remarkable health of my animals. 
"My horses have not been sick an hour, and the heaves are unknown in my stable, which may fairly be attributed to the fact that no musty hay ever enters my barn; and, it is probable, that the milk of cows may be as unhealthy, if they eat badly cured hay, as if fed on what is called swill in the cities.

"Haring these corers always at hand, it has been my practice to mow my grass when it was ready, without consulting the almanac, or waiting for a change of the moon; and the result has been, that I have had more than my share of good luck in this important branch of business.

"They are also very useful as a protection against heary dews; and as a cover for coarse clorer and Timothy I consider them indispensable.

"After long experience, I have found the most approved method of making hay covers, which may be used for wheat and other grain crops with great advantage, is to take stout, unbleached cotton sheeting, of a suitable width, say from thirty-seren to forty-five inches wide-the latter is the bestcut it into squares, and attach to each corner, by a string, or otherwise, a pin made of wood, twelve or fifteen inches long, cut off smooth at one end and rounded over at the other, which completes the affair. The size of the pin should be about an inch in diameter.

"Hemming the selrages is a matter of fancy, as they would do very well without it; and if a tannery is near by, it would greatly improve them by plunging them into a rat for two or three days; this would thicken up the cloth an inch or two, and make it more durable, as well as much more effectual. A decoction of bark, with alum, or some other astringent, would probably answer equally as well, but this is not necessary, to make an excellent hay cover. Like a cotton umbrella, the first dash of a heavy shower would cause it to spatter through for a moment, but would do little or no harm. I doubt whether a larger size than forty-five inches square, or forty-frve by fifty, would be desirable,-mine have been not much over thirty-six inches square.

"At the suggestion of sereral practical farmers of this State, the Messrs. Chases \& Fay, of Boston, are now establishing an extensive manufactory for the purpose of furnishing the agricultural community, throughout the country, with a ready 
made article at the lowest possible price; but, judging from the extensive use of the covers last year, in consequence of articles published in agricultural journals in the United States, as well as Canada, it is doubtful whether they will be able to supply a quarter part of the demand. The article made by them is shown in Fig. 109."

A farmer of Norfolk says: "I have nerer used them myself, but they are used in the neighborhood to good advantage. A neighbor of mine who has used them for three years says they have been worth to him this year the whole cost, as with them he has been able to get all his hay in in good order, while a large quantity, where they were not used, was made nearly worthless by the long continued wet weather."

But on the other hand, a farmer of Middleser county says: "I have never used hay caps, not having faith enough in them to give them a trial. My objections are, that they camnot be of any use as a permanent shelter, but only in a sudden showerand then we have no time to put them on. We can sare more hay by putting it in cocks and trimming well than by corering with canvas cloth. In fair weather the eap would be decidedly injurious, as it would prevent the escape of rapor or steam. Cocks of hay that are left to stand in the field orer the Sabbath are often dried enough in the upper half. But in case caps were put on for Saturday night the drying would not advance on Sunday unless you should make it a business to remore them on Sunday forenoon."

A permanent structure for corering and protecting hay stacks is described by a farmer of Bristol county as follows: "I have a structure called a hay cap, which, if farmers hare not sufficient barn room, I think would be economical, as hay can be more rapidly secured than in the common stack, obviates the necessity of fencing, and prevents the hay from becoming wet while the stack is open for feeding. This cap is twelre feet square and consists of two sills fourteen feet in length and eight inches square, four posts five inches square and seventeen feet long framed into the sills one foot from the end of the same. The sills are held together by two girts framed into the post just above the sill. The posts are held firmly by girts placed five feet eight inches above the sills, to which height the box part of the structure is loarded. The posts above the box 


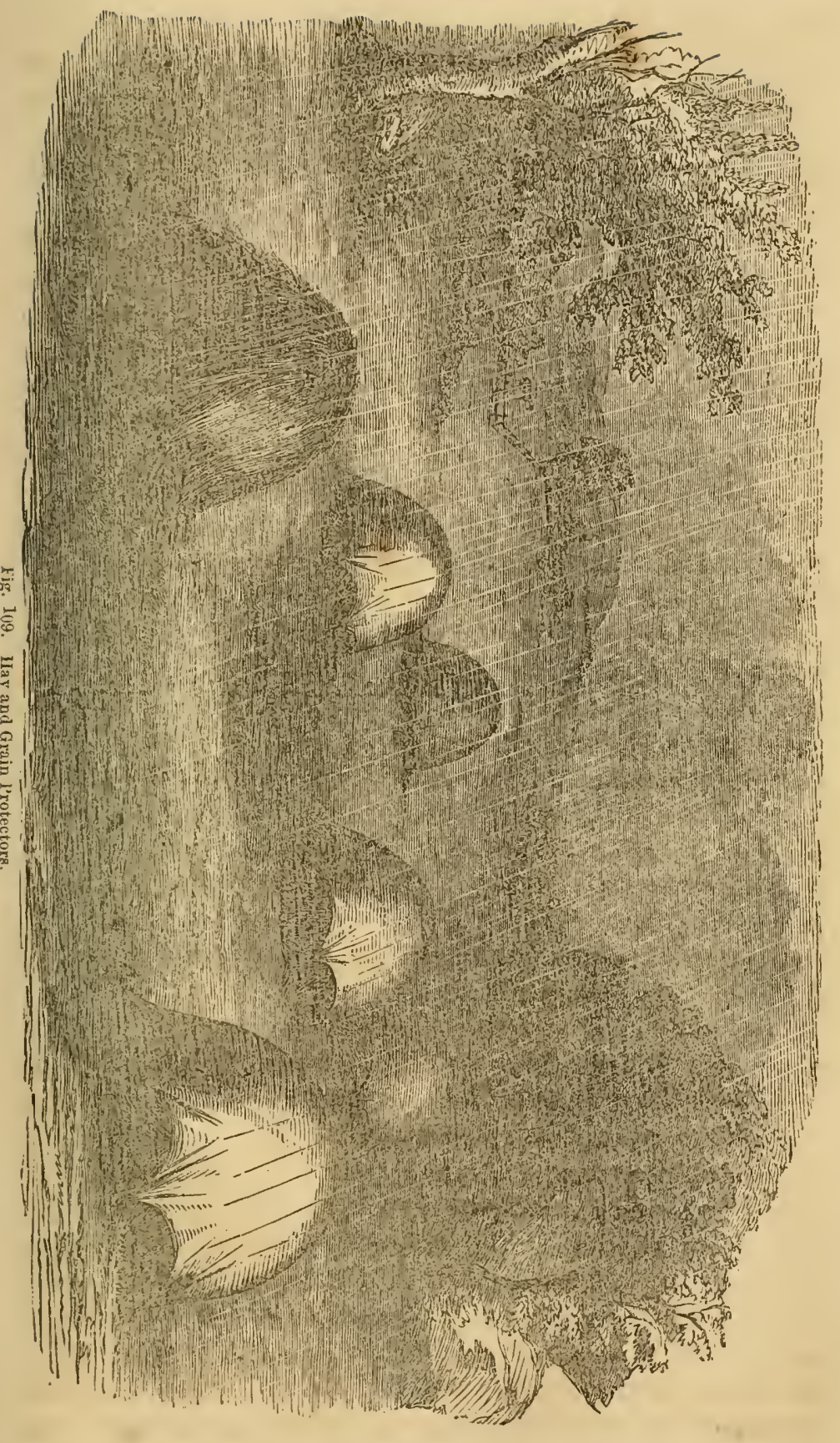



are perforated with holes one foot apart for the insertion of pins to sustain the cap or cover. This (in form of a pyramid). should be made as light as possible, so that it may be readily raised by placing the shoulder under the corner. 'The frame of three by four joists, must be large enough to full outside the posts and admit of some play. The rafters are small joists nine feet in length, the feet resting upon short pieces of joist placed across the corner of the frame, thereby forming openings for the posts to pass. The tops of the rafters are nailed together orer the centre of the frame. Girts should be placed lialf way from the eares to the point of the roof to nail corering boards to. These should be good halfinch stuff, and run from the eares to the rafters. The top of the post should be kept from spreading by stay lathing them. A hay cap of the dimensions giren, will hold fire tons of hay. The cost I do not know, as this was on the place at the time of my coming on to it."

\section{FALL FEEDING.}

This is the term applied to feeding off the aftermath of mowing lands. This practice is very prevalent, and is justified by experienced farmers rather on the plea of necessity than any other, since most farmers, of careful observation, admit that it is, on the whole, injurious. A large proportion of those who are in the habit of fall-feeding, speak like the following, from a practical farmer of Middlesex, who says: "I feed off slightly, although it would probably be better for the next crop if I did not. My cows, lowerer, like it, and as they pay me well at the milk pail, I like to see them enjoy themselres." Another, in answer to the questions, "Do you feed off the after-growth of your mowing lands in the fall? Do you think it an injury or a benefit to the field to feed it off?" says: "I do generally, but consider it an injury to the field." Another says: "I do feed off, moderately, the after-growth of my mowing fields, and beliere the grass worth much more so fed than if left on the ground to rot. $A$ dense mass of dead grass is also much in the way of the scythe and the rake the next year." A practical farmer of Worcester county says: "I feed off the after-growth of mowing lands only when I am compelled to do so in dry seasons for want 
of pasture. I think it an injury to feed off, unless there is a large growth, which is better to be fed off, so that it will not fall down and heat the roots and kill them."

Another says: "I feed my mowing lands in the fall and think it is a bencfit to the field in all cases where a top-dressing is used, and of no injury to an old field that is plonghed once in three or four years. Where a large growth of after-fecd remains on the land it is like mulching trees, kills the grass roots and makes a grand shclter in winter for mice."

A farmer of Hampshire comnty says: "I feed it off and then top-dress it, and think it a benefit to the land, but should consider it an injury if I did not top-dress."

An experienced, practical farmer says : "I feed it off, but think it an injury to the field to do so, and I should much prefer not to fecd mowing lands at all. The grass holds in longer and is of better quality. I feed it off because it is necessary to eke out a comfortable support for my stock." And another: "To some extent. I do not think it beneficial to the land to feed much erery year, nor rery injurious to feed some; but to fecd close, I decm highly injurious."

A very experienced farmer of large olservation, in Plymouth comnty, says: "To some extent, I feed it off, not from choice but conrenience. The treading of the cattle is some injury, and they feed on the best kinds of grass and leare the wild grasses to extend the area of their growth. In my experience, mowing grounds are kept in the best condition by taking off the first and second crops with the scythe, and biemially dressing with compost manures."

This accords with the experience of another practical famer who says: "My practice is to feed the after-growth or mow it. To take all from the soil without returning an equivalent, would be injurious. My custom is to top-dress my mowing gromuds with good compost manure, about fifteen cart loads to the acre, once in two or three years-a portion of lots in one year and a portion the next. Where the ground is not liable to wash-carry the manure off-I prefer spreading the manure in the antumn; it is dissolved by the fall rains and winter snows, and the grass is benefited in the early spring."

An experieneed farmer of Essex county says: "Farmers here are in the habit of feeding off their mowing lands in the fall, 
but hare no doubt that the erop of grass would be better the next season, not to feed them. Some think the injury not so great as the value of the feed of the after-growth."

A practical farmer of Franklin county says: "I have had considerable experience in both ways, and do not think fall feeding is any injury if it is not fed too close; prefer feeding to mowing the second crop, and prefer feeding with sheep than cattle." And another: "The feeding of dry mowing injures it by causing it to run out, learing the roots exposed to the winter, while moist land is injured by the cattle's feet much more than the ralue of the feed, in both cases taking all off and learing nothing to renovate the land another season."

An experienced farmer in the same county, and one of the best grazing towns in the State, says: "It is now more than twenty years since I have allowed any kind of domestic animal to feed upon our mown lands, and my opinion previously has been fully confirmed by my experience. It is a decided benefit to let the after-growth remain upon the land; it is a protection from summer's drought and winter's cold. Some of my neighbor's are following my example." And another: "I sometimes feed of my after-grass. When I do feed it off, I take good care to feed it early and leave a good growth to protect the roots of the grass from frost in winter. I think it an injury to feed; mowings will last longer not to be fed at all, and the land when broken up will produce a better crop of corn or potatoes than if fed."

From these extracts it will appear that the practice of fallfeeding is very general, while the good judgment of practical farmers almost unanimously condemus it as injurious, especially to feed closely and late in the season. The reasons assigned for the practice are chiefly, the necessity generally felt for feed at that season of the year, and the importance, in some situations-particularly on interval lands-of removing all protection for the mice, which frequently prore rery destructive to the roots when buried with the snow in winter. All condemn the practice of too close feeding, under all circumstances.

The fall growth collects the elements of a thrifty growtl in the following spring. These are stored up in the roots orer winter for the early use of the plant. If it is elosely fed, the spring growth must be proportionably later and fecbler. 


\section{GENERAL TREATMENT OF GRASS LANDS.}

The importance of haring the ground well tilled and thoroughly prepared by liberal manuring before committing the seed to it, is too apparent to need remark. When the seed is sown, it is the common practice to harrow it in, either with an iron tooth, or a bush or brush harrow, or both, and those who adopt a more careful culture follow these operations with a thorough rolling, which compresses the soil and usually causes an earlier germination of the sced. The importance of this last opcration, that of rolling, is too often orerlooked. By reference to table XV., the importance of corering at the proper depth is also apparent, since it will be secn that a large proportion of the seeds germinated with a very slight corering.

But if one thing more than another may be said to lie at the foundation of all real improvement of grass lands, or lands under a course of rotation, it is a proper system of drainage. Especially is this important for low, wet lands, since it not only frees them from superfluous water, thus making them more susceptible of tillage in early spring, but actually increases their temperature several degrees, in some cases as much as from eight to ten, and rarely less than from two to four, and admits the air to circulate more frecly around the roots of the plants. The aquatic grasses require large and constant supplies of moisture, and when the soil is changed by drainage, the more valuable species of grass may be introduced and cultirated in it. But one of the most important questions which the farmer of New England has to meet, is the proper treatment of his pasture lands. Many of our old pastures have been stocked hard time out of mind, and the grasses in them liave been literally starved out rid grow thin of necessity, while, as the finer and nutritious grases disappear, nature very kindly corers up the nakedness of the soil with moss, as an evidence of the effect, and not the cause of porerty. "They are said to be "worn" or "run out." Many of them are grown orer with bushes and briars and other equally worthless pests, till they carry but one animal to four or fire acres, and often require twice that amount 
to keep an animal on foot, to say nothing of fattening him. It is a well known saying that, "Poor pastures nuake breachy cattle."

Undoubtedly thousands of acres in this State would be far more profitably corered with pines than with eattle, and many an observing farmer is now convineed of this fact; but still we must have pasture lands, and there are ciremmstances where it becomes important to improre them and increase their productiveness. Some of them are so situated that they can be ploughed and thus brought in, with other cultivated lands, to the general rotation; and where this can be done, it may be, on the whole, the best and most economical mode of improving them.

A well known farmer of Woreester county says: "I have renovated my old pasture land by pulling up the bushes by the roots, scarifying the foul or mossy places with the harrow, and sowing on grass seed and clorer, both red and white." Another says: "Plough, manure and re-seed. Some have sown rye with the grass seed and then let the stock feed on the rye, as it will not produce any seed-stalks-it sometimes lasts three years. This method has been put in practice with marked suecess. On our hills, ground plaster or gypsum has brought in the white clover the next year after sowing." A practical farmer of Iliddlesex says: "The best method I have found is to plough in forty loads of good stable manure to the acre, plant, hoc, and kill the bushes and moss, then seed dowin with redtop and white elover, instead of taking a crop of rye without adding any thing to the soil, then seeding down with 'barn chaff' as many do." An experienced farmer of Hampden county says: "If the pasture lands can be ploughed, do it in the month of June, say seren inches deep, harrow thoroughly, sow one hundred pounds of Peruvian guano and three pecks of buckwheat, per acre, harrowing them in at the same time. Sow as much grass seed and of the kind best adapted to the soil as you please, and bush it in. I have tried twenty acres at a time with good success."

Another says: "It can be done in various ways. I hare a piece of pasture land near my house that bore hardly a spear of grass, and nothing else, except fice finger and other weeds that usually grow on old, worn ont pine plains, and I commeneed twenty-four years ago by sowing Timothy and redtop and a bushel and a half of plaster of Paris, per acre, once in two years 
up to this time; the grass increased from year to year so as to corer most of the land in thirteen years. Ten years ago I commencel ploughing it. I ploughed about one acre and put on fifteen loads of compost manure and planted it with com. I sowed it down in the fall with rye, Timothy and redtop, and sowed clover in the spring, and about a bushel and a half of plaster of Paris, per acre. The next year I plonghed another part and manured it the same, except that I planted this with melons, dunged in the hill, seren feet apart, and then sowed it down in the fall the same as the other piece. The next year I took up the remainder, and all the manure I put on the piece, except in the hill, was the water carted on it from a hole in my barnyard. It was immediately ploughed under, then holed and dunged in the hill seren feet apart, planted with melons, and in the fall sowed as the other parts. Since that it has continued to bear very large grass. When I hare tumed my cattle into it the first of June, I hare judged, and others who have seen it, that had I not pastured it I might have cut a ton to the acre. The soil of this picce consists mostly of sand resting upon a subsoil of grarel. Most of our pastures are spoiled by feeding off too early in the spring and orerstocking. Cattle should not be turned in till the first of June, and then not orerstocked, so that there will always be spots of grass to go to seed, which will keep the pasture well stocked with grass. Always keep your pasture stocked with grass; if you cannot keep it on any other way sow on Timothy and redtop and harrow it in, once a year. I prefer to do it in August, but any other month in which you are most at leisure, will do.

Another experienced farmer says: "Old pastures should be ploughed and planted when they are not too rough for those operations. They may then be seeded down in July among corn or heans, or grain may be sown with the grass seed in the following spring. But we have too much rough pasture unfit for the plough. It should never have been cleared for pasturing, but should have been left to run to rood. Such rough lands are often much improved by sowing plaster at the rate of two hundred pounds per acre. Plaster generally works well on clays and clayey loams which are not wet." Another says: "Where I have ploughed and planted old pastures and then seeded anew, the cattle get a much better liring." One of the 
best famers of Norfolk county says: "Fither by ploughing, rolling and sowing down grass seed and grain in September or April, or ploughing in manure after remoring the crop on old ground, and cross plough in the spring, then spread and harrow in guano, at the rate of three liundred pounds per acre, or a good dressing of compost, and sow Rhode Island bent, or redtop and white and red elover, with some variety of grain; or by scarifying mossy ground, and sowing in grass seed and harrowing it, then applying three liundred pounds of gruano, or one bushel and one peek of salt, or ashes from ten to twenty bushels, per aere, harrow and bush the ground. Sow early in fall or spring."

I farmer of this State who has lived and had a large observation in England, says: "Some furmers say the plough. But in England, where old pastures are seldom broken up, I hare known extraordinary results from top-dressing with crushed bones, more particularly on the large dairy farms in Cheshire. I am sorry I cannot give you the quantities. A neighbor of mine has harrowed an old, worn out pasture, dressed with a liberal coating of Barrilla ashes, from six to seren cords per acre, and sowed white clorer and rolled it. It came out a beautiful pasture. 'The brush harrow and roller applied to all grass land in the spring will amply repay for the labor. Breaking and spreading the cattle droppings on the pasture land is well worth attending to." $\perp$ farmer of Worcester county says in answer to the sixteenth question of the cireular:

"This depends on the kind of land to be reclaimed. If it can be ploughed I would plough it and plant it with potatoes or something else to make it mellow and fine, and then sow it to grass. If it is too rough or stony to plough, - which is the case with a large share of the pasturing in this section,-but is good, sweet, warm land, I would feed it with shcep. I hare a pasture of this description, that a few years ago was corered with briars and bushes so thick that there was but rery little grass upon it; I cut off the bushes and put on sheep enough to eat erery thing that grew upon it for four or fire years. They have killed all the briars and most of the bushes. I have sowed some plaster of Paris, which is all I lave done to it, and now one acre is worth, and will produce more feed, than three would ten years ago. I should say that my sheep have always done mell on this pasture. If the Iand is cold and 
wet, and inclined to grow bushes, I let it go and never try to reclaim it, unless it is near the buildings or near the village where the land is very high. In that case it may pay to ditch and work it into good smooth land."

Another practical farmer of great experience says: "We have a varicty of soil in this town; some of the best of pasture lands, stony soils, generally clay subsoil. Plaster of Paris is our renovator for pasturage. It works most admirably on almost all of our lands. Two humdred pounds to the acre, applied once in two or three years in early spring, will keep our pastures good." Another in Plymouth county says: "The best method I have ever used is to fence in small pieces and then stock hard with sheep. Feed it down till no green thing remains, then turn the sheep off days and on nights till September, then harrow the land with a sharp harrow and sow on grass seed, keeping the cattle off the remainder of the season."

An experienced farmer of Middlesex says: "It will improre an old pasture merely to plough and re-seed it without manure, but this is a slow mode and not to be recommended where it is possible to apply some sort of dressing. A better method is, withont doubt, to plant for a year or two, manuring well, before sowing grass seed. The soil by being thus thoroughly stirred, and exposed to atmospheric influences, will gire a sweeter grass and perhaps more of it. But it is not always convenient to plant a part of a pasture. In such cases great bencfit would result from simply ploughing, manuring and seeding to grass immediately."

But perhaps the best disposition that can be made of many of our poor, thin pasture lands, and one which has incidentally been alluded to, is to take the eattle from them entirely and cultivate them with forest trees. 'This is frequently recommended in answer to the question proposed in the cireular. A farmer of Midalesex county speaks in the following words: "Old worn out pasture lands that cannot be renorated by gypsum or ashes, had better be sufiered to run up to wood. Pine lands can be seeded in the fall with a crop of winter rye, or without. Pine seed can be obtained by taking pains to collect the burs before they are open and drying them in some place where they can be threshed. This is white pine seed year." 
This, I am conrineed, will be found to be perfectly practicable, and a rapid growth of pine wood, internixed, as it should always be, with some deciduous growth like the white bireh, will be found to be more profitable than the use to which they are now put.

I know many pastures of good strong soil, never ploughed within the memory of the living, some of which are known not to have been ploughed for a hundred and fifty years, which require from cight to ten acres to a cow, so entirely buried are they in moss and hushes. Such lands can be planted with pines at a small cost, and would soon be covered with a growth which would pay a large percentage on the outlay. I have, during the past season, cxamined over fire hundred acres of cultivated pines in different parts of the State, varying in age from three months to twenty years, and can testify to the surprising rapidity with which such a plantation will corer the ground, concealing the fact of their being planted by the hand of man, and assuming the appearance of a dense forest. In one instance the owner informed me that his plantation had averaged him a cord to the acre every year for twenty years during which it liad been planted, while the land, a light barren sand, had apparently beci improved, and a thick undergrowth of hard wood was apparently ready to sueceed the pine when the opportunity offered. I hare seen a growth of pitch pine, malle this year, of over two feet six inches in length by measurement, and a growth of white pine, made in the same time, of two feet nine inches. The past year was an exception, for while generally the growth of wood is intermpted by the drought during the hottest months of summer, and then starts ont a new growth in the antumu, it continued with extraordinary vigor all through the season, in those parts of the State which were farored by frequent rains. . The average growth would not, of course, equal that stated above.

But still, there are circumstances, and they are not by any means unfrequent, where it is both practicable and desirable to take other methods of improvement for pasture and grass lands, and we come now to consider more in detail the 


\section{TOP-DRESSING OF GRASS LANDS.}

The idea was formerly entertained that pasture lands were sufficiently enriched by the animals which fed them. Practical men begin to think otherwise, for it is found that a profitable return is made for the little outlay which they require. Particularly is this the case with pastures fed by milch cows. They do not return the essential elements of the plant to the ground in so large a proportion to what they take from it, as some other animals. These elements are required in great quantities to form their milk, while in other animals they are required only to form bone and muscle. The ordure of cows is, therefore, less raluable and fertilizing than that of other animals. The consequence is, that lands fed wholly by cows are exhausted sooner than those fed by other animals. For it is evident that where more is taken from the soil than is returned, exhaustion must follow.

We furnish animal and regetable matters to the earth, to supply it with substances which the growth of plants has taken from it. It will be obvious, on a moment's reflection, that the constituent parts of the plant are taken up from the cartlı and the air, in much the same manner as our food and drink become our bone and flesh. The analogy is still more distinet when we reflect that all our applications for the improrement of the soil, are nothing more than the supply of food for plants. For the food of plants is found in all manures, and the value of these depends upon the quantity they contain.

The methods of renorating mowing and pasture lands by means of top-dressings, do not essentially differ. An interesting experiment, not long ago, fell under my observation. On different parts of the same field, common meadow mud, rich barn and liquid manure impregnated with lime, were used as a topdressing. The mud was hauled out in the autumu and thrown in heaps, and there left to the action of the frosts and snows of winter. In spring it was spread about the same time the other manure was applied. Strange as it may seem, the top to which the mud was applied, appeared to far the best advantage. The grass was heavier, and after the crop had been removed, that 
part of the field on which the mud was applied, came in more quickly and luxuriantly than the rest. This field was a light, gravelly soil, which had not been under very high eultivation. Many of our soils are composed of gravel with a mixture of sand. These soils need the constituents of marl and meadow mud. Marl and mud contain the carbonate, or in some eases the sulphate of lime, or plaster of Paris. They contain a mixture of clay, which sandy or gravelly soils need. And on these soils clay mud has been found to do the best. Peat mud is a rich regetable food, and if a small proportion of potash, or ashes, be added, it is valuable as a manure. Light soils are always improved by any substances which make them firmer and more compact. Stiff clay soils, on the other hand, are benefited by applieations which make them lighter and more permeable. No one of the three kinds of earth, sand, clay and lime, when ummixed with the other varieties, would be capable of supporting regetation. The mixture of them, when any one predominates, will correct and improve them, for the fertility or soils depends much on the proportion of these constituents. In some marls the clay predominates. These should be used on the light sandy soils. In others the sand predominates. These are adapted to stiffer lands. The practice of mixing soils has always been attended with suecess when judiciously managed.

Nor is this application of mud and clay any new fact to the practical agriculturist. The county of Norfolk, in England, is said to owe much of its great fertility to this source. The greatest European improvements in sandy. soils, have been made by these means, in Belgium. As intimated in the experiment alluded to, it has always been found best to expose the mud or clay to the action of the frost. It becomes mellowed. so that it may be spread evenly upon the ground. Peat mud is composed of regetable matter which has been accumulating for ages. When taken fresh it is found to contain an amount of acid which would make it improper for immediate use. Exposure to the frost, wind and rain, entirely nentralizes the acid properties. Ashes, or potash, would hare the same effect.

These substances may be said rather to ameliorate and improve the texture of soils than to furnish immediate sustenance to the plant. And in this view they camnot be too strongly recommended, for we hare never known them to fail of having 
beneficial effects, both on pasture and mowing lands. And besides, the application of them is so simple, so much within the reach of every farmer, that it is well worth the trial. If the soils are much worn, or very barren from a great preponderance of any particular carth, a liberal allowance will be required. Ordinarily, as in the experiments which have come under my notice, some twenty-five or thirty cart loads to the acre have been found sufficient to increase very greatly the prodnetireness of the land. A still less quantity would be of essential service. Nor is.the expense of this application so great as some imagine, for almost every farm contains a quantity of waste peat meadow, and elay is frequently near at hand. It may be removed and prepared at a season of the year when there is but little else to do. The expense, therefore, need not deter any one from its use.

But there is another substance equally accessible, which acts both as an ameliorator and a fertilizer of the soil. It is, perliaps, one of the cheapest and most profitable top-dressings. It is the rich loam which accumulates in the holes by the road side, and wherever the wash gathers from hills. Every one has observed the effect of the loam thrown out upon the grass in ploughing. The grass along the edges soon becomes greener in spring, and grows with greater luxuriance. The wash by the road side would have a far more powerful effect. For this contains, besides the putresent animal matters, from the road, a quantity of sand, which rich soils wanting closeness and consistency, require on the surface. Spread upon such soils when covered with grass, it is very efficacious, and often makes the vegetation as vigorous as stimulating manure. Experiments have clearly shown that the effect of sand on some soils is to operate as a manure.

Among the mineral manures, lime lias sometimes been used as a top-dressing. Its effect arises not so much from any direct nutriment furnished by it to the grass, but from its influence on the substances in the soil. It hastens the decomposition of vegetalle and mincral matters in the earth. In this way it renews cxhausted soils. It increases the temperature of cold, sour lands after being drained. It causes a rapid decay of peat substances. Hence its use in the compost heap. It destroys th: mussus and coarse herbage which work in among the grasses, 
and indicate the want of lime in the soil. It produces from them a finc, regetable mould, by cansing the white and red elorer, and some natural grasses, to eome in thicker and thicker each year. Lime produces a more marked effect on the grasses than on any other crop. It seems, very frequently, to increase the nutritive quality of the grasses as well as to increase their quantity, by assisting them to elaborate the juices, the albuminous substances and the sugar, in which their value as food for stock largely consists.

But lime can never supply the place of other manures. 'T'here are properties which it camot supply, which plaster ean; other's which it cannot supply, as bones can; and other's which it cannot supply like ashes, and manures that contain salts. There are situations, howerer, in which it is invalualle. On reclamed meadow lands, after thorough draining, and a corering of three or four inches of gravel, a top-dressing of lime has a beneficial effect. Crops of grass of two and three tons to the acre, have been taken after such a dressing of lime. In many cases the first crop will repay the expense of bringing such land into cultivation. In these situations, then, as well as on many pastures, it may be called one of the most useful applications that can be made. Such lands will bear an abundant supply of lime without cxhaustion. But on poor sandy soils it should nerer be used. It will soon exhaust and may render them completely barren. When it meets with elay in lands to which it is applied, it forms a kind of marl, and greatly improves the texture of the soil. But when it comes in contact with sand, it forms, rather, a sort of mortar. Hence it is thought to be injurious on sandy soils. Many soils have naturally a sufficient quantity of lime, and on these a further application is not neerled.

No definite rule, with respect to the amount required, can be giren. It must depend upon the nature of the soil, and must be left to the judgment of those who use it. In general, on peat and clay soils, from ten to fifty bushels to the acre will be required, though less would, perhaps, be beneficial.

The addition of lime to the compost heap is often of great importance. The decay of all regetable substances is accelerated by it; but it should not be brought in contact with decaying or fermenting animal substances unless covered by a thick 
coating of peat or other absorbent. Whenever lime is used in a compost-muless it be for the special purpose of hastening the fermentation of regetable substances-it ought to be mixed with salt by dissolying the salt first in water and slacking the lime with it. A bushel of salt will thus prepare four bushels of lime. Refuse brine will answer very well.

We come now to the use of ashes as a top-dressing. Of this we may speak with more confidence. For while experiments with lime have not invariably prored suecessful, owing, probably, to the soils designed to be benefited, we know of no instances in which the application of ashes has not fully repaid the expense. If farmers would bear in mind that ashes contain all the elements which assist the growth of plants, they would be unwilling to part with a substance which they might turn to such profit. If the quantity is small, let it be husbanded with the greater care, instead of being sold, with the idea that so few can do no good. One substantial farmer says: "I am now, more than ever, fully persuaded of the ralue of ashes as a manure. Nothing in the whole catalogue of manures, compares with them on my land. The soil was a thin, clayey loam, and where the ashes were sown there was a crop of excellent clorer, where for years the land had been almost unproductive."

Grasses are often more benefited by ashes than other crops, since they require a greater amount of the salts which ashes contain. For all permanent mowing lands, especially on the lighter soils, ashes are among the cheapest of manures where they can be had in sufficient quantities. In parts of Flanders and. Belgium, countries in which the science of agriculture has becn carricd to a high perfection, the great loss of regetable matters from the soil is constantly restored by ashes or bones, together with other manures to be mentioned hereafter. Indeed, almost all agriculturists, both in Europe and America; have attached very great importance to the use of ashes. In some parts of Germany they are held in so high esteem that they are transported to a distance of eighteen or twenty miles, to be used as a top-dressing. According to Prof. Liebig, with erery one hundred and ten pounds of leached ashes of the common beech tree, spread upon the soil, we furnish as much phosphate as fire hundred and seren pounds of the richest manures could yield. Phosphates are highly useful to all kinds of soil. (, 
There can be no doubt that the process of leaching takes from the ashes a part of their fertilizing propertics. For many uses this is no oljection. Especially is this the ease near the sea, where leached ashes are thought by some to be eren more serviccable, as the salt in the atmospluere the more readily combines with them. Erery practical man has heard of the amazing effects which bone dust has upon the soil. Yet this is valuable, chicfly, for the phosphate it contains. But if we may rely upon the statement of Prof. Liehig, leached ashes also contain a large amount of phosphate of lime, which would show them to be extremely valuable. But suppose we allow four bushels of leached ashes to one bushel of erushed bones, the expense of the ashes, would, in most cases, be less than the bones. But if bones can be procured, a mixture of leached ashes and bones, four bushels to onc, forms a rery useful application. The compound should remain a week or two before being used. Those who have tried leached ashes, have been fully satisfied of their superior qualities as a fertilizer. Careful experiments, by practical, conservative men, show that land producing onc ton to the acre, has been, so improved by this means as to yicld three tous to the acre. Where thirty bushels were used on threc-fourths of an acre, in one instance, the crop was increased more than three-fold. Nor are leached ashes subject to the oljections which are raised by some against the use of lime. They do not apparently exhaust the soil. The effect of them is felt for several years. Many farmers have found by experience, that one bushel of mleached hard rood ashes is nearly equal to two busliels of plaster, as a top-dressing for the dryer grass lands. If this be true, what has been said would show that leached ashes are about equal to plaster in their effects on such lands. A peck of lime is commonly used in leaching a bushel of ashes. This, of course, adds to the value of leached ashes for grasses. They contain, also, a portion of the alkali which is decomposed by the action of the atmosphere, and the water in the soil prepares it for the food of plants.

As we hare spoken of the use of peat muck, it is proper here to say that ashes may be mixed with muck in the proportion of six or eight bushels to the cord. The muck is better, as usual, dug in the autumn, though the mixture might be made in the spring, or on application to the soil. If leached ashes 
are used, the proportion may be about one to three. In this case, the two substances mutually assist each other, and the compound is, perhaps, better than either alone wonld be. So potash added to peat muck, makes a valuable compound.

In this connection we should allude to the practice of burning sea-weed as a manure. The ashes of it are spread upon grass and pasture land. They form a very useful and powerful stimulant, but the process of burning sea-weed causes the loss of its most fertilizing qualities. The most common and efficient mode of application is to carry it directly upon the grass as a top-dressing. The coarse rock-weed and kelp decay in a much shorter time than the fine sea-weed, and are, no doubt, better than this. Whenever sea-weed is used, it is best on sandy or gravelly soils. From twenty-five to thirty, or even forty cart loads to the acre, are sometimes applied. Peat ashes form, in some cases, a raluable top-dressing for grass and pasture lands. In Holland, where erery fertilizer is preserved with care, peat ashes as well as wood and coal ashes, are highly esteemed. The great value of the first is well known to many, and if those who have them will spread them upon grass at the rate of fifteen or twenty bushels on the lighter, and thirty or forty on the heavier soils, they will be abundantly repaid.

If what has been said be true, and it is the result of many experiments, some of which have come directly under my own observation, farmers would do better to buy ashes on the return of every spring, than to sell them, as is often done.

Of the use of gypsum, or plaster of Paris, the most contradictory opinions lave been cxpressed. So far as my observation goes,-and I hare both seen and tried many interesting experiments on the old soils of this State, and the newer soils of Maine,- - the application to moist soils has been satisfactory. It has been said that plaster does not benefit natural pastures. This, I apprehend, depends chiefly on the character of the soil. In one instance, a large pasture which had become worn and somewhat unproductive, received a generous top-dressing of. plaster. The grass started sooner, and continued throughout the season to look far better than the adjoining pastures of preciscly the same soil. So far as could be ascertained, the increase in grass orer the adjoining pastures, was about seventy-five per cent. Nor was this all. This pasture eame in the next season 
with the greatest luxuriance, and its load of beautiful green was the wonder of the neighborhood. Its effect on clover and Timothy is greater than on other pastures. Many have supposed that plaster would exhaust the soil. This would not seem to be the case, for as it takes four hundred and thirty parts of water to decompose one part of plaster, its decomposition is slow, and consequently its infuence is felt for sereral years. How, then, can it have such immecliate and bencifial effects? It retains the fertilizing gas which is constantly rising from fermenting regetable matter, and gives it up at a proper time for the nourishment of the plant. It does not, like lime, canse regetable matters to decay, but rather when they decay, holds their most important parts from escaping.

The powerful odor which rises from decaying regetable matter, from the stable, from the manure heap, and imperceptibly from the whole surface of the earth, is one of the most important elements for the growth of the plant. Plaster fixes this, and the first shower washes it into the earth to fecd the roots of plants. The relative value of manure depends, in a measure, upon the amount of this strong odor, this ammonia which it contains. This gas, commonly known as hartshorn, is an execedingly powerful stimulant. Nor will it appear unimportant, when we bear in mind that two and onc-quarter pounds of this ammonia, lost by fermentation, is equal to the loss of one hundred and fifty pounds of grass or grain. Scientific men will say that this gas is taken up in the atmosphere by the rain, and descends with the rain to fertilize the earth. This is true. This ammonia, arising from all fermenting manures, so indispensable to the earth, is not lost forever when it flies away into the air. But does not the shrewd farmer perceive that as much of this as he allows to escape from his own lands, by neglect, falls upon, and improres the fields of his neighbor as much, and perliaps more, than his own? Is it not evident that by saving all that he can, and by receiving whatever the genial rain brings with it, he gets a double benefit?

If the effect of plaster is such as we have described, no one can fail to see how important are the functions it may be made to perform. But it also adds a certain amount of lime and sulphur to the earth. It is composed of these substances for the most part, and hence called by chemists, sulphate of lime. 
We shall have occasion to speak of its use in connection with other manures, when we speak of the compost heap. We now allude to its use by itself, as a top-dressing.

On some soils it is not so satisfactory as on others. But our pastures are many of them covered with the white honeysuckle. These are often called clover lands. On all clover lands, whether reserved for pasture or mowing, plaster generally has a wonderful influence. A bushel, or two bushels to the acre, have been known to double the crop, and to add more than twenty times its own weight to it. Even greater results hare followed. For if we may believe one of the most distinguished chemists, ${ }^{*}$ every pound of nitrogen which we add to the grass, increases the produce one hundred and ten pounds, and this increased produce of one hundred and ten pounds is effected by the aid of a little more than four pounds of gypsum, or plaster. Another accurate investigator-Sir Humphrey Davy-found by actual experiment that the ashes of an acre of red clover, contain no less than three bushels of plaster of Paris. This important fact proves that the earth already contains a large amount of this substance, and that it is essential to the growth of clover. This may, perhaps, explain the so-called clover sickness in some land. The requisite supply of plaster has been exhausted. In any case, the addition of plaster to clover lands, and especially to pastures, is of the highest importance.

The effect of chareoal is somewhat similar to plaster. Charcoal will absorb ninety times its own bulk of ammonia, which is held from escaping till it is separated by water and carried into the earth for the plant. When dry, the operation of fixing the gas is repeated till the next shower sends the gas into the earth, and the particles of water take its place in the chareoal. In this way, as a top-dressing, charcoal as well as plaster, performs the most important functions. If we take any decaying animal matter, which has begun to give off its offensive and noxious odor, its ammonia, and cover it with charcoal or plaster of Paris this escaping gas is immediately stopped. No disagrecable odor arises from it. The decay of the substance has suddenly ceased. 'This simple fact will show the intelligent farmer to what purposes these substances may be applied. His choice of these should depend somewhat on the expense of pro-

* Boussingault. 
curing them. The relative expense depends so much upon circumstances, that we need not make the estimate. As an absorbent and retainer of the valuable properties of manure, peat mud and loam will also be found of essential service. If used on a high and dry soil, the effect of plaster will not be very apparent the first season, unless like the past, there are frequent rains.

There is an impression among many that plaster does not produce so good results in the immediate vicinity of the sea shore. If this is so, it does not arise, probably, from the proximity to the sea, but from other causes. Many of our lands do not need the applieation of plaster. I have seen it used, to the best adrantage, within two miles of the sea. If there were any thing in the sea air to prevent plaster from performing its usual functions as an absorbent, the effect would be pereeived to a far greater distance inland. If any failures lare occurred in its use in the ricinity of the sea, they were probably owing to the soil rather than to the atmosphere. There is one other remark in this connection. When plaster has been applied without immediate effect, we should not at once conclude that it is useless on the particular soil to which it is applied. The first season may be dry, and ill adapted to its decomposition. In such cases, good results have ordinarily followed the second year.

The great utility of bones as a manure, arises from the large amount of phosplhates which they contain. On all pastures which hare been long fed, the phosphate of lime is exhausted. It is constantly taken from the earth in the grass, to form the bone, the musele, and the milk of animals. Of the earthy matter in bones, nearly five-sixths consist of phosphate of lime and magnesia. Nitrogen is also abundant, and, of course, ammonia, for nitrogen is an element of ammonia. A few bushels of bone dust will often quite restore old, "worn-out" pastures. Indeed, almost every part, of which bones are composed, goes directly to the nourishment of regetable life. The ashes of all grains are very rich in phosplate of lime. This shows the importance of furnishing this element for their use.

A mixture of crushed bones and ashes, or leached ashes, forms a valuable top-dressing. Nor will this application, in small quantities, be thought expensive, if what is said be true, 
that the animal part of bones, which amounts to about onethird, contains eight or ten times as much ammonia as the manure of the cow, and that the fertilizing salts in bones are sixty-six times the amount of a like quantity of the manure of the cow. So that a smaller quantity of bone dust will answer the purpose of a much larger quantity of manure from the stable. We can but hope that erery furmer will try the experiment. It may be done on a small scale, at first, though in the vicinity of every butcher's establishment, bones can commonly be procured in any quantity.

Thus far I have spoken of manures which belong more peculiarly on the surface, as a top-dressing for grass. For though they are sometimes used, especially plaster, on plonghed land, with potatoes and other crops, yet their influence on the surface is thought to be far more effective. Indeed, the benefit of lime, plaster and charcoal, would, in a great measure, be lost were they to be buried to any depth in the eartl. But there are other manures which are often used as top-dressings.

One of the best practical farmers of Hampden county, says: "I top-iress almost all of my mowing in the fall, cut two crops on all of them, and on some a third. I make a compost of earth and manure-make in the lot where it is used, by ploughing off a thin turf on the lower side of a small hill or knoll, taking the turfs to the hog-yard, and then cart from the stable three, five, or ten loads, or more, as I have the manure. Drop the manure upon the ground that the turf was remored from, then plough on the upper side of the hill and shovel two loads of earth upon each load of manure, beginning in the spring, so on through the season. As the manure of the barn increases, cart to the meadow, placing it upon the upper side of the first heap and plough and shovel as before. From one hundred loads of good stable manure it makes three hundred loads of good compost, and will make as much grass as so many loads of stable manure. For grass, put ten cart loads, per acre. Spread in the fall upon mowing, this compost makes more grass than green mannre carted and spread upon mowing in the spring. In almost all cases the knoll or hill carted until it is level with the adjoining ground, produces more crop than befurc."

Another, in Berkshire county, says: "Top-dressing for mow- 
ing lands is very beneficial, but too expensive, if barnyard manure alone is used, so much passes off by craporation. $\Lambda$ compost of one-half or two-thirds turf or swamp muck, and oncthird grood manure, is quite as benefieial to the land, and probably better or more enduring than all manure. If ashes are mixed in this compost it is all the better. But if stal)le manure alone or in compost is to be applied, it should be in autumn, so that the frosts of winter may incorporate it with the soil."

Another farmer, of great experience and observation, in Plymouth county, says: "I top-dress generally late in the fall; but should prefer early spring dressing, if we could cart on the fields without injury, and the time eould be spared from other business. My land is "chiefly of a cold, tenacious soil, and a compost is made of one-fourth stable manure and three-fourths light loam. For warm land peat mud would be used instead of the loam. Twenty common ox-cart loads, from thirty-three to thirty-five bushels each to the acre, is as small a dressing as can be judiciously applied. Double that quantity would not be excessire." A practical farmer, of Norfolk county, says: "With respect to top-dressing for mowing lands, I would state, that for several years we have been in the habit of raising from one to three acres of early potatoes for market. We have usually dug them early in Angust, and before the tops were dead. The tops are taken directly from the field, and spread on the mowing lands, to very great advantage. We think the tops from an acre of potatoes sufficient to top-dress an acre of mowing land, and the effect is equal to three or four cords of good manure."

The practice alluded to in this extract is worthy of a careful trial by those who are so sitnated as to adopt it. It is known that the tops of potatoes contain a large pereentage of the organic elements of plants.

Fromberg found in $100 \mathrm{lbs}$. of the leares in a natural state, from .82 to .92 per cent. of nitrogen, and that $100 \mathrm{lbs}$. of leares dried contain from 5.12 to 5.76 per cent. of nitrogen. If his results are correct, and there is no reason to distrust them, we add to the land $50 \mathrm{lbs}$. of inorganic salts, besides nearly $20 \mathrm{lbs}$. of nitrogen among the organic constituents of every ton of potato tops. This would make a ton of them equal in value more than two tons of the best Ichaboe guano. 
In a case which I have in mind, a very poor, worn out grass lot, was top-dressed with fourteen ordinary cart loads of good stable manure to the acre. The quantity of grass was increased fourfold. Clover and Timothy came in as luxuriantly as on any new laid piece. If the top-dressing were repeated once in fire or six years, there would be no danger of exhanstion, though there would be an adrantage in loosening the earth with the plough. But the use of stable manure should be confined mostly to mowing land. On closely fed pastures it would be injudicions, from its exposure to the sun. On these, ashes or plaster would be better.

An Essex county farmer says: "Peruvian guano, mixed with loam, is unquestionably the best nanure for top-dressing that ean be found. $\Lambda$ shes are very good for lands that are liable to be washed by the fall and early spring rains. I should think that the spring would be the best time to spread it, but on lands not so situated the fall would be more proper. In the latter case the manure would be entirely mixed in around the roots of the grass, and all the strength of the manure would remain in the ground."

An experienced and intelligent practical farmer, of Bristol county, says: "I top-dress moist mowing lands in winter or early spring, with eight or ten loads of fine manure, or with about 300 lbs. of guano, mixing the guano with twice its bulk of dry sand moistened with water containing about two onnces of sulpluric acid in solution to the gallon of water."

No farm should be managed without a compost heap, since it may be so made as to form an extremely valuable article for top-dressing. A quantity of meadow mud should be dug out in the autumn for this special purpose. Two cords of peat mud, added to one cord of good stable manure, will make, in the estimation of many practical farmers, a compost of thrce cords of valuahle manure. This has been tried repeatedly, and is constantly done by those ambitious to excel in farming. To this compost heap should be added, from time to time, all the animal and vegetalle matter adapted to ferment and enrich the soil. Woollen rags, the remains of fish, the blood and flesh of animals, the hair of animals, all these make an exceedingly rich manure. $\Lambda$ most intelligent gentleman connected with a wool factory, informs me that a cord of matter collected at the establishment, 
is worth at least five or six eords of the best stable manure, for a top-dressing. This we cannot doubt, for here are the blood, the wool, pieces of the skin of the animal, a little lime, and many other substances, all collected together. A fermentation takes place, by which the richest gases are formed. Such a compost heap, with an addition of loam and mud, would be invaluable for a top-dressing. But though in most cases all these substances cannot be procured, many of them ean, and should be saved by every one who is desirous of improving his land. Those who are near the sea, or near the market, can procure an abundance of fish to add to the compost. Nothing is better for soils than this. A little lime added to the heap, causes its rapid and thorough decomposition. Ashes should also be added. When additions of manure are made, they should be corered with mud or loam, to prevent waste.

We need not enter more minutely into the details of forming the compost heap. It is sufficicut to say, in a word, that every thing capable of fermentation should be added to it. The lower layer should be of loam or mud. Nothing is more common among farmers, on the death of a horse or any other animal, than to throw the body away. It is estimated by some, that the body of a single horse, when divided and mixed with peat mud and loam, will make a compost worth fifteen or twenty loads of the best and richest manure. This is, perhaps, too high an estimate, but animal substances ferment rapidly, or rather they may be said to putrefy without fermenting, so quick is their decomposition. If leares, grasses, moss, straw and other substances of like nature, are used, lime will be useful in causing their rapid decay. When these are well fermented, the heap should be thrown orer, and if made long and narrow, so as to expose the greater surface to the air, it will be the better.

The value of a compost, properly made, is greater than the aggregate value of the several ingredients applied separately, no matter what or how rich they may be. Besides, some divisor is needed for concentrated or other powerful manures, by means of which they may be more crenly and judiciously applied. Peat, or dry meadow muck, is one of the best and most arailable of these divisors, if properly prepared by exposure to the influence of air and frost. No good farmer would erer use lime in compost with barnyard manure or animal substances, unless 
peat muck, gypsum or charcoal were largely used in the same mixture.

Animals fed on rich food make far the most valuable manure. This will serre, in part, to show why the manure from the sty is so fertilizing. Swine are fed on a great variety of rich food. The actual profit of raising them, arises mainly from the amount of substances they will mix together and make into good manure. If the sty be supplied, at intervals, with mud, loam, and other regetable matter, the furmer will not complain of the cost of these animals.

Liquid manures are highly useful to grasses. Care should be taken to apply them, also, to the compost heap. The richness of manure from the sty is due to the quantity of liquid matter it contains. Hence the importance of adding a great variety of regetable substances, loam, and mud. In a word, it may be said, that all liquid manures contain a large amount of nitrogen, which is one principal ingredient of ammonia, to which we have alluded. The importance of saving the liquid of the stable, either with the compost, or to be applied by itself, may be seen, also, in the fact that the exceeding richness of guano, and the manure of all fowls and birds, is due to the union of the liquids and solids.

After fermentation has taken place in animal manures, in the compost or elsewhere, they may be spread without much loss by evaporation, and hence it matter's not whether the top-dressing is applied in the autumn or in the spring. Plaster is better spread in the spring, when the moisture of the earth makes it immediately arailable. Some prefer the autumn for spreading compost manures, while others prefer the spring, just before the thick grass surrounds and protects them from the sun and wind. The soil, in autumn, is not injured by the loaded eart, as is liable to be the case in spring. Others still, apply them after the first mowing, and before the summer rains. The new crop preserves the manure from drying up and wasting. This, lowerer, is ordinarily too busy a season to attend to it with convenience.

We have then, these several methods of improving our pasture lands. First. 'To allow some of them to run to wood, or which is far better, to plant them with forest trees, which 
should never hare been entirely cut from them. This applies to poor, thin soils at a distance from the homestead.

Second. To plough and cultivate where this can be done on strong, good soils, which are not too stubborn and rocky. This applies to many lands which have been used as pastures time out of mind, the soils of which are naturally good, but have rum out from neglect. Put soil into a good state of culture and rich and nutritive grasses will fourish as naturally as weeds. The former are nearly as spontaneous on good soil; as the latter are on poor ones. The suceess will depend chiclly on good culture if this mode is adopted.

Third. To scarify the surface thoroughly with a sharp tooth harrow, sowing on a suitable mixture of grass sects spoken of above, and then harrow and brush over again, the work to be done in September or very early in spring, if the surface is hard enough to go over with cattle without too much poaching. This applies to old pastures corered with moss, where the sweet grasses are run out, but which from their particular location may not be desirable for woodland, nor pay for a more complete and careful improvement.

Fourth. To mix the grass seeds as evenly as possible with a funely divided compost and use it as a top-dressing, first harrowing the surface to loosen it, and after spreading the compost, brushing it orer with a brush harrow to break up the lumps. This will cost a little more than the preceding method, but the grass seed will start sooner, make a larger and finer growth the first season and give greater satisfaction. This applies to very much the same class of lands as the preceding. In both eases, if the pasture, or any part of it is eovered with bushes, they should of course be cut or grubbed up ; if it is wet or covered with stagnant waters they should of course be drained ofi so as at least to leave a dry and healthy surface. It is unnecessary to say that the top-dressing should be free from weed sced, and be in a finely divided state. This method of improvement is perfectly practicable on thousands of acres which are now in a state both discreditable and unprofitalule to their owners.

Fifth. To pasture sheep, turuing in as many as the pasture will carry, stocking, in other words, pretty closely, for a few years. The first objection that many farmers raise to this method is, that the cost of fences is great, and that it is a branch 
of husbandry with which they are not acquainted. This may be so, but the testimony of those who have tried this method is uniformly in its favor. I have had some experience and considerable observation in sheep husbandry, and my attention has been called to the changes wrought by sheep upon rough pastures covered with bushes and briars in part, and it appears to be a practicable method of improvement, while the raising of sheep and lambs for the shambles, is destined to be a profitable branch of farming.

IRRIGATION.-Another practicable means of improving our grass lands is by irrigation. Every casual observer, even, is familiar with the fact that lands are fertilized by irrigation, and especially that the grass by running streams shoots earlier in spring and makes a far more thrifty growth than lands on the same kind of soil which liave not the advantage of running water. The introduetion of the hydraulic ram among the implements of the farm, offers facilities for irrigating grass lands, not hitherto known, and it will unquestionably become liereafter an important means of guarding against our severe summer droughts, and of increasing vastly the production of our lands.

It would be impossible to state with any detail the different methods adopted to effect the objects of irrigation, since it would require a distinet treatise upon the sulject, and it is sufficient to allude to the simplest mode employed with suecess, and the advantages offered.

Superficial irrigation, which is, perhaps, the oldest and the most common form in which water is artifieially applied for the purpose of increasing the growth of grass, was undoubtedly suggested by observing the wonderful effects arising from the overflow of rivers. Remarkable examples of this are familiar to many, as the annual or periodical overflowing of the Nile, where the water without being left to stagnate upon the surfaee, is moving gently over it, depositing whatever alluvial matter it may loold in suspension. The extraordinary richness of the Valley of the Mississippi, and on a smaller scale, of the Valley of the Connecticut and other rivers, is mainly due, also, to this kind of irrigation; and this is imitated in our attempts to conduct the water over grass land by a system of shaliow, open 
drains, which take the water from its natural channel, keeping a constant flow without allowing it to accumulate in any part.

The process of surface irrigation is not so simple as many would suppose. It requires considerable skill and practice, and many failures have followed experiments of this kind, made without due care and attention. Sir John Sinclair, however, in speaking of this operation calls it one of the "casiest, cheapest and most certain modes of improving poor land in particular, if it is of a dry and gravelly nature. Land when once improved by irrigation is put into a state of perpetual fertility, without any occasion for manure or trouble of weeding, or any other material expense; it becomes so productire as to yield the largest bulk of hay, besides abundance of the rery best support for ewes and lambs in the spring, and for cows and other cattle in the autumn of every year. In favorable situations it produces rery carly grass in the spring, when it is doubly valuable; and not only is the land thus rendered fertile without any occasion for manure, but it produces food for animals, which is converted into manure to be used on other lands, thus augmenting that great source of fertility."

The effect and value of irrigation does not depend altogether upon the artificial supply of moisture which it furnishes to the plant. "The mechanical action of the irrigatory current of water, in exercising the plants, strengthening their organisins, keeping their stems and root crowns clear of obstruction, promoting the equable circulation of water and oxygen around them, and causing an equable distribution of the soluble materials of their food, probably plays a considerable part in irrigatory fertilization. The differences of effect, from the mere circumstance of flowing or stagnation of the water, are prodigious; for while flowing water coaxes up the finest indigenous grasses of the climate, and renders them sweet and wholesome, and nutritious, and luxuriant, stagnant water starves, deteriorates, or kills all the good grasses."

The effect which surface irrigation produces on the nutritive qualities of the grasses may be seen by reference to the tables of analyses found in a preceding section.

This subject ought to receive the careful attention of the enterprising farmer. Eren a farmer of very limited means may do 
something each year towards improving his pasture lands. Ho may lessen the area of the bushes, he may plough up a small piece at least, and seed down at once with grass seed and winter rye, either in the spring or in the fall, and in either case his stock will fare enough better to pay for it, and the next year he may take another piece in the same pasture till the whole is finished, when it will carry more stock, and more stock will give him more manure, and more manure will increase the fertility of other lands, and increased fertility will add to his means of further improvement. The difficulty with most small farmers is to begin. Well begun is half well done, for the moment any real improvement is begun in earnest, the interest is excited, the mental actirity is increased, the desire for improvement partakes the nature of a passion, and hence, thongh the beginning may be small, the ending may be the renovation of the owner as well as the land.

In conchusion, I have one farther suggestion to make, and that is, as to the propriety of encouraging the collection of grasses for exhibition at the annirersary festivals of our agricultural societies. It would be an easy thing, I think, to engage many in this fascinating pursuit. Some, undoubtedly, would be interested by the simple suggestion, but the offer of small premiums for the largest and best arranged collection would induce others to attempt it who now want something to stimulate them to the work. The premium, however small, might afford the necessary stimulus, and if an interest were once excited, the subject would be still farther pursued, till many others were interested, while the collections, if properly named, would do much to disseminate a higher knowledge of the exhaustless riches of this class of plants.

"The royal rose-the tulip's glo:v-

The jasmine's gold are fair to see;

But while the graceful grasses grow,

$O$, gather them for me!

Thr pansy's gold and purple wing,

'The snowdrop's smile may light the lea;

But while the fragrant grasses spring,

My wreath of them shall be!" 


\section{INDEX OF SISTEMLTIC NAMES.}

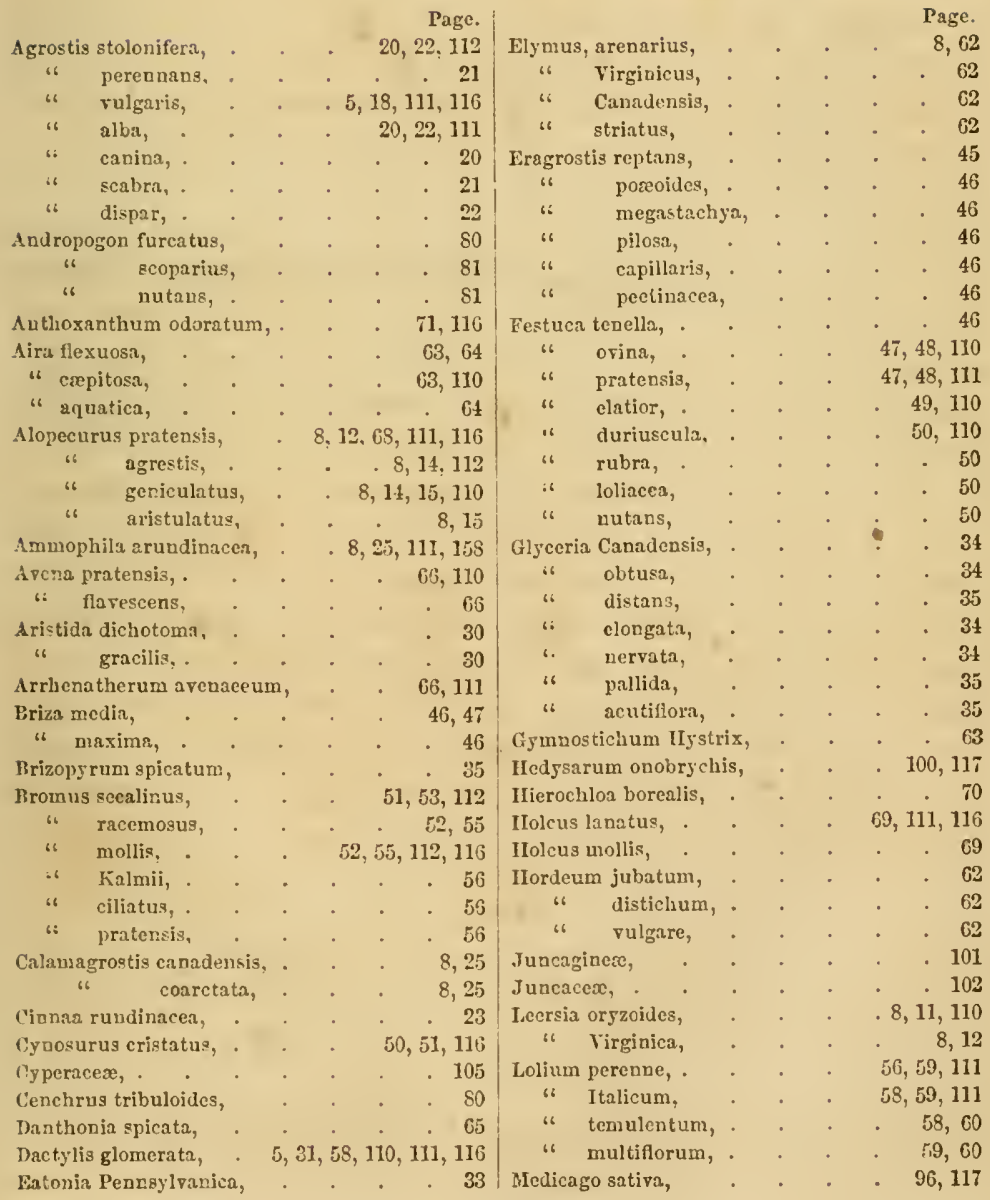




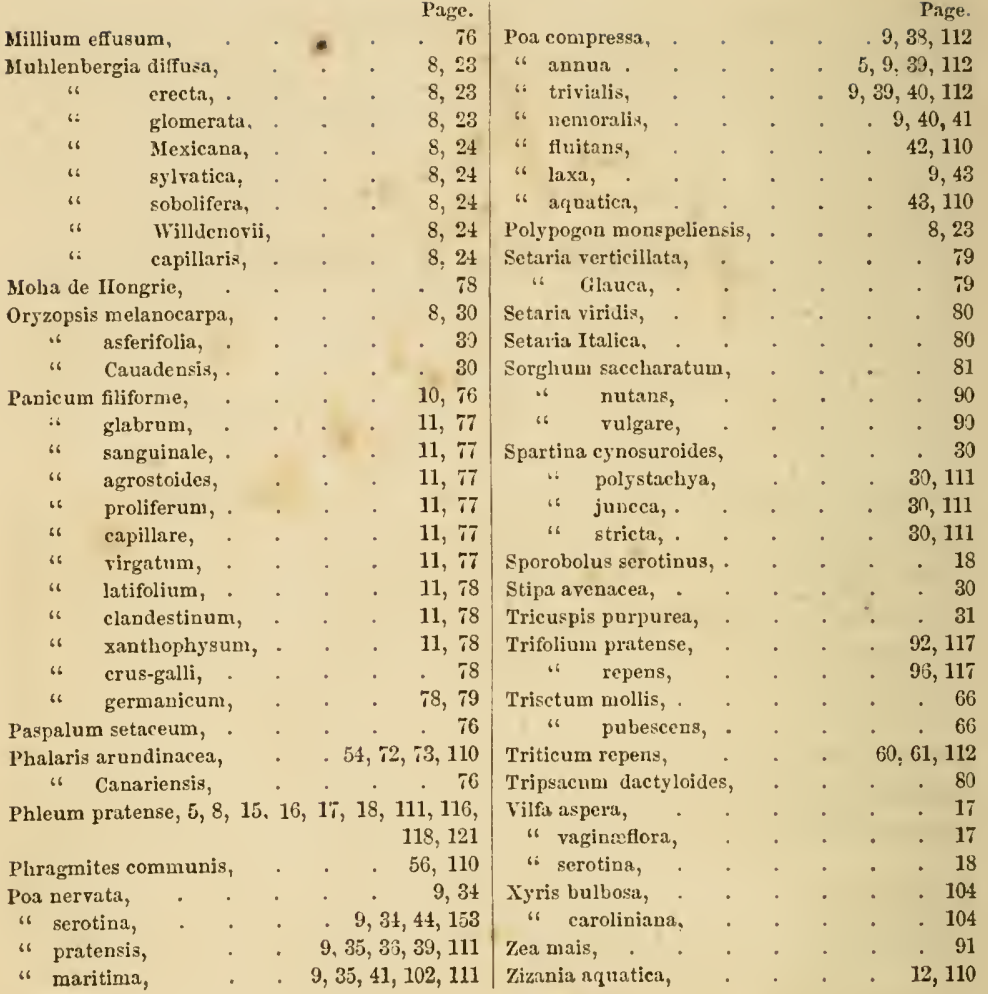




\section{GENERAL INDEX.}

Aftermath, growth of,

Alfalfa,

Allen's Mower,

Ammonia, importance of, .

Analysis of the Grasses, .

Annual Beard Grass,

Annual Spear Grass,

Arrow Grasses, list of,

Ash of the Grasses, analysis of,

Ashes, use of, as manure, .

$17,113,201,203$

- $96,97,99$

$170,174,175$

$217,218,223$

$74,118,121,124$

. 23

$35,39,112,116,118,121$

. 101

. 124

214, 216

Barn Grass,

Beach Grass,

" " culture of, .

$25,26,28,111,146,158$

$26,28,29$

Bearded Darnel, .

Bengal Grass,

Black Grass,

Blue Grass,

Blue-joint Grass, .

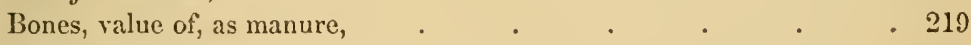

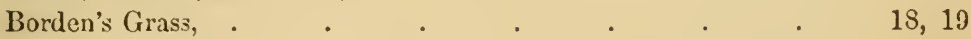

Bottle-brush Giass, . . . . . . . . 63

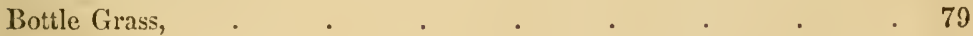

Brown Bent, . . . . . . . . 20

Bristly Foxtail, . $\quad$. $\quad$. $\quad$. $\quad$. $\quad$. $\quad$. $\quad$. 79

Bur Grass, . $\quad . \quad$. $\quad . \quad$. $\quad . \quad$. 80

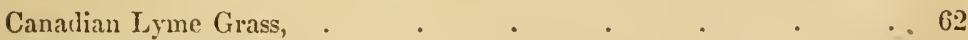

Chandler Grass, . $\quad$. $\quad$. $\quad$. $\quad$. $\quad 601$

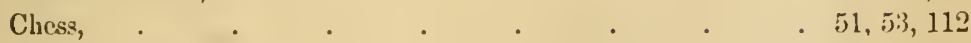

Chinese Sugar Cane, . $\quad$. $\quad$. $\quad$. $\quad 81, \$ 3,85,90$

Cireular Letter, . $\quad$. $\quad$. $\quad$. $\quad$. $\quad$. $\quad$. $\quad 128$

Climate-its effect on regetation, _. . . . $130,131,132,136$

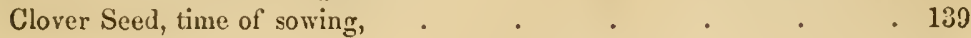


Clover, mode of curing, .

186,188

Common Reed Grass,

56,110

Common Manna Grass,

42, 110

Common Canary Grass,

Common Spear Grass,

Compost, modes of forming;

$35,37,38$

$220,221,223$

189, 190

Corn Folder, curing of, .

Couch Grass,

$60,61,112$

Creeping Meadow Grass, .

Crecping Soft Grass,

Crested Dog's 'Tail,

Curing, methods of,

45

69

$50,51,116,118,121,146$

185,187

Darnel,

Drainage, importance of, .

Dew Grass,

Downy Persoon, .

Downy Oat Grass,

201, 225

18,20

66

$65,69,111$

English Bent,

20

Fall Feeding, practice of,

Fall Seeding,

201, 203

$137,139,140$

False Redtop,

False Rice,

Feather Grass,

Field Barley Grass,

Floating Meadow Grass,

Floating Foxtai!,

Flyaway Grass,

Finger-spilied Wood Grass,

Finger Grass,

Fiorin,

Food of Animals, .

Forest Trees, culture of, .

Fowl Meadow Cirass,

Fresh Water Cord Grass,

Fringed Brome Grass,

Finetop,

Fowl Meadow Grass,

Gama Grass,

Goose Cirass,

Grasses, growth in sun and shade,

" effect of soil and seasons
" nutritive value of the,
" list of the,

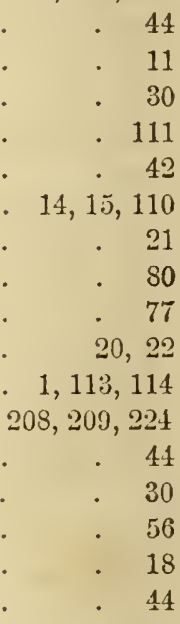

80

$41,42,102,103,111$

$131,135,137,128$

$2,113,128,130$

$112,113,115,119,121,122,161,120$

$118,142,114,147,151,158,160$

$8,110,111,110$ 
Grasses, importanee of the,

$1,6,112$

" classification of, .

" description or natural history of,

" technieal terms applied to the, .

" flowers of the,

" time of cutting, .

" analysis of the,

" time of sowing,

Grass Lands, treatment of

" " top-rlressing of,

" drainage of,

Grass Seed, morle of buying,

$\begin{array}{lll}\text { " } & \text { " weight of, } \\ \text { " } & \text { " } & \text { time ormination of, } \\ \text { " } & \text { " } & \text { selection of, } \\ \text { depth of covering, }\end{array}$

Green Foxtail,

Green Meadow Grass,

Gnano as a top-klessing, .

Hassock Grass, $2,5,7,8,110,113$
$2,5,7,11$ to 112
$2,5,6,7$
$3,5,7$

$161,162,164,166$

$54,118,120,121,122$

. 137

$201,207,208,224$

. 210

. 204

141,145

$145,146,148,159$

$6,131,142,146,147$

137,140

141,142

- 146

. 79

$35,37,38$

205, 222

Hairy Slender Paspalım, .

Hair Panicled Meadow Grass,

IIair Grass,

IIair Stalked Panic Grass,

Hairy Meadow Grass,

Hay, nutritive value of, .

" curing of,

Hay Caps, use of, .

" " permanent,

IIard Fescue Grass,

Heath's Mower,

Hoove in Cattle, .

Horserake, nse of,

Hungarian Millet,

Indian Corn,

Indian Millet,

Indian Rice,

Indian Grass,

Irrigation, effect of,

Italian Rye Grass,

. $63,110,146$

. 76

46

- 21

. 77

46

$103,104,109,126,127$

181,183

196, 199

200,201

$50,110,116,118,121,146$

$175,176,177$

101,101

$191,193,195$

78,80

$6,91,92,115,189,190$

. .90

. .12

. $\quad 90$

$118,121,123,226,226$

$58,59,60,111,118,121,123,146$

$35,37,38,118,121,146$

Kentucky Blue Grass,

$35,37,38$

Ketehum's Mower,

171,173 
Late Drop Seed, .

Lawn Grasses, mixture of,

Long Panicled Manna Grass,

Lucerne, culture of,

Lyme Grass, nutritive value of,

Manny's Mower, .

Manures for Grass Lands,

Meadow Fescue Grass,

Meadow Brome Grass,

Meadow or Swale IIay, .

Meadow Spear Grass,

Meadow Soft Grass,

Meadow Oat Grass,

Meadow Foxtail, .

Millet Grass,

Mixtures of Grass Seed, .

Mountain Rice,

Mowing, height of,

Mowing Machines, use of,

" " premiums for,

Nitrogen, importanee of, in food, . Nutritive Value of Grasses,

Nutritive Equivalents, tables of, .

Nerved Manna Grass,

Nitrogen, value of, in plants,

Nodding Fescue Grass,

Oil Cake, effect of, as food,

Orchard Grass,

Over-seeding with few species,

Pasture Grasses, .

Pastures, turf of old, " renovation of, .

Perennial Rye Grass,

Poverty Grass,

Prolific Panie Grass,

Quaking Grass, .

Quitch Grass,

Rattlesnake Grass,

Redtop,

Red Clover,

$$
\begin{aligned}
& \text {. } \quad . \quad \text {. } \quad . \quad 18 \\
& 153,15 t \\
& 96,97,99,146 \\
& \text { - } 120,122 \\
& 168,169,175 \\
& 205,210,214,219,222 \\
& 47,48,111,146 \\
& 56,57 \\
& \text { 103, 104, } 109 \\
& \text {. } 34,118,121
\end{aligned}
$$

114,115

$112,114,118,119,120,121,126,163$

125,127

- 34

. 114

50

. 115

$5,31,32,58,110,111,116,118,121,146$

159

$148,151,152,166$

148, 149

$205,209,210,224$

$56,57,110,146$

30

77

$46,47,118,121$

60,61

34

- $5,18,111,116,118,121,146,148$

$92,93,95,119,120,122,146,148$

186,188 
Reed Canary Grass, " " " nutritive value of, .

Red Fescue Grass,

$49,50,140$

Rhode Island Bent,

Ribbon Grass,

. 19

Rice Grass,

. 73

11,110

Roots of Timothy Grass, .

Rough Stalked Meadow Grass,

Rush-like Grasses, list of,

Rush Grass,

Rush Salt Grass, .

$64,165,166$

$39,40,112,118,121$

101,102

- 17

30,111

Salt Marshes, ditching of

Salt Marsh Grass,

Salt Reed Grass,

Sand Grass,

Sainfoin, .

Sea Spear Grass,

Seasons, influence of

Sedges, list of,

Seed, selection of,

Seneca Grass,

Shade-its effect on the quality of grass, .

Sheeps' Fescue Grass,

Slender Crab Grass,

Slender Foxtail,

Slender Spiked Fescue,

Slender Meadow Grass,

Slender IIairy Lyme Grass,

Small Fescue Giass,

Smooth Crab Grass,

Soil-its effect on the grasses,

Soils, mixture of,

Soft Brome Grass,

Squirrel-tail Grass,

Star Grasses, list of,

. 104

30,110

30,111

. $\quad 31$

$100,120,122,146$

$41,42,102,103$

$128,130,132,137$

. 105

141,142

. 70

$128,135,136$

$47,48,110,146$

. 76

. 14

$50,51,146$

- 40

. 62

- 46

- 77

$2,19,113,144$

211, 223

- 112

. 62

. 104

163,179

Starch, transformation into woody fibre, .

Striped Grass,

. 73

Stooking of Corn, practice of,

Sugar, manufacture of,

Swale Grass,

Sweet-scented Vernal Grass, '

Swale IIay, value of,

- 190

$81,82,89$

$104,105,109,112$

$71,116,118,121,146$

$54,105,162$

Tall Fescue Grass,

$49,110,146$

Tall Smooth Panic Grass,

Tall Oat Grass,

. 77

Time of cutting grass for hay,

$66,68,111,146,116,118,121$

$161,163,161$ 
Timothy, $5,12,15,16,17,60,116,118,121,123,143,163,164$

6. sown with Clover, $17,144,148$

" time of 'cutting,

Tickle Grass,

Top-dressing of grass lands,

- 166

Treatment of grass lands,

Tufted Hair Grass,

Twiteh Grass,

21

$210,212,221$

$20 t, 207,209,224$

$63,110,146$

$60,61,112$

Upright Sea Lyme Grass,

62

Vanilla Grass,

Vegetation, conditions of,

Velvet Grass,

- 70

130,131

69,146

Water Hair Grass,

64,65

Water Spear Grass,

43,110

Wary Meadow Grass,

- 43

Weather-its effect on regetation,

$2,128,131,135,136$

Weeds, analysis of,

White Clover,

White Grass,

White Top,

Wild Oat Grass, .

Willard's Bromus,

Wire Grass,

IVild Chess,

Wild Rice,

Wild Water Foxtail,

Wild Rye,

Woburn Experiments,

Wood IIair Grass,

Wood Neadow Grass,

$2,128,131,135,136$

$96,97,120,122,146$

$20,65,111,146$

11,146

Wood Reed Grass,

51,112

38,112

56

12,110

15

- 62

113,114

63,61

40

23

Yellow Oat Grass,

$66,118,121,146$

Yellow-eyerl Grasses, list of,

. 104

Iipratum.-On p. 102, fixth line from the bottom, for p. 49, Fig. 30, read p. 41, Fig. 30 . The same occurs in the last line on the sane page. 


